Universidade de São Paulo

Faculdade de Filosofia, Letras e Ciências Humanas

Departamento de Letras Clássicas e Vernáculas

Programa de PÓS-GRADUAÇÃo EM LETRAS CLÁSSICAS

\title{
IMAGINES AMORIS
}

As Figurações de Amor em Roma

do Final da República ao Período Augustano

Lya Valéria Grizzo Serignolli

Orientador: Prof. Dr. Paulo Martins

Versão Revisada

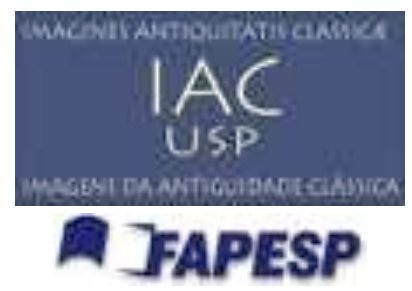

São Paulo

2013 
Universidade de São Paulo

Faculdade de Filosofia, Letras e Ciências Humanas

Departamento de Letras Clássicas e Vernáculas

Programa de PÓS-GRADUAÇÃo EM LETRAS CLÁSSICAS

\title{
IMAGINES AMORIS
}

As Figurações de Amor em Roma

do Final da República ao Período Augustano

\author{
Lya Valéria Grizzo Serignolli \\ Orientador: Prof. Dr. Paulo Martins
}

Dissertação de Mestrado apresentada ao Programa de Pós-graduação em Letras Clássicas do Departamento de Letras Clássicas e Vernáculas da Faculdade de Filosofia, Letras e Ciências Humanas da Universidade de São Paulo.

Financiada pela Fundação de Amparo à Pesquisa do Estado de São Paulo FAPESP.

Versão Revisada.

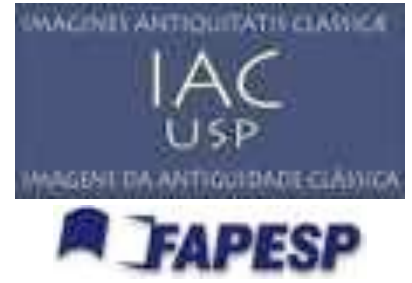

São Paulo

2013 
São Paulo, 10 de julho de 2013.

\section{Banca Examinadora}

Titulares:

Prof. Dr. Alexandre Pinheiro Hasegawa (FFLCH - USP)

Prof. Dr. Luiz Armando Bagolin (IEB - USP)

Suplentes:

Prof. Dr. João Angelo Oliva Neto (FFLCH - USP)

Prof. Dr. João Batista Toledo Prado (UNESP)

Prof. Dr. Brunno Vieira (UNESP) 
Imagines Amoris

As Figurações de Amor em Roma

do Final da República ao Período Augustano

Palavras-chave: Amor, imago, loci, poesia latina, artes

\title{
Resumo
}

Esta pesquisa estuda as figurações do deus-personagem Amor em Roma entre o final da República e o Período Augustano, em poemas de Catulo, Virgílio, Horácio, Tibulo, Propércio e Ovídio; e em objetos de arte como pinturas, esculturas, moedas e mosaicos pertencentes ao mesmo período, que apresentem loci, temas e motivos análogos aos da poesia.

\section{Imagines Amoris}

The Representations of Amor in Rome

from the Late Republic to the Augustan Age

Key words: Amor, imago, loci, latin poetry, arts

\begin{abstract}
This reasearch concerns the study of the representations of the character-god Amor in Rome from the Late Republic to the Augustan Age, on the poetry of Catullus, Virgil, Horace, Tibullus, Propertius and Ovid; as well as in art objects such as paintings, sculptures, coins and mosaics, from the period in focus, which present loci, themes and motifs analogous those found in poetry.
\end{abstract}




\section{Agradecimentos}

Agradeço imensamente a todos os profissionais e amigos que contribuíram de diversas maneiras como esta pesquisa: ao meu orientador Paulo Martins pela amizade e apoio incondicional neste projeto e ao longo da vida acadêmica, e pela sugestão do tema; aos professores Leon Kossovitch, João Adolfo Hansen, Giuliana Ragusa, João Angelo Oliva Neto, Alexandre Hasegawa, Marcos Martinho dos Santos e a todos os professores e colegas do Departamento de Letras Clássicas e Vernáculas da FFLCH - USP pelo constante incentivo e diálogo na universidade; aos professores e staff do Classics Department do King's College London, especialmente ao diretor Henrik Mouritsen pelo convite e autorização para participar das atividades acadêmicas; e aos professores Martin Dinter, Will Wooton e William Fitzgerald, supervisor do meu estágio BEPE de pesquisa, pelo interesse, diálogo e inestimável ajuda neste projeto; à FAPESP pelo financiamento da pesquisa de mestrado e pela concessão da Bolsa BEPE de mestrado, que abriu as portas do King's College London, do Institute of Classical Studies, e dos museus e sítios arqueológicos da Europa, onde pude aprofundar e aperfeiçoar ainda mais esta pesquisa; aos profissionais do The British Museum, especialmente Ian Leins, do Departament of Coins and Medals, e Alexander Reid do Department of Greek and Roman Antiquities pela autorização para a realização de visitas técnicas; aos colegas do grupo de pesquisa IAC: Cynthia Dibbern, Henrique Fiebig, Rosângela Amato, Melina

Rodolpho, Cecília Lopes, Irene Boschiero, Mayara Pereira, Gustavo Borghi e Christine Fonseca; e, finalmente, a pessoas que contribuíram com a pesquisa por outras vias que não a acadêmica, em especial à minha amiga, professora de Inglês e madrinha, Evelina Rios Meyer; e à querida amiga e professora de yoga, Priscila Kurmeier, "Namastê!"; aos meus pais, Neuza e Pedro Serignolli, e a toda a minha família, especialmente ao meu Amor, Mário Bianco, muito obrigada por tudo, sempre. 
Amori meo

Mário Bianco 


\section{Índice}

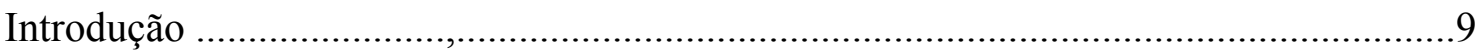

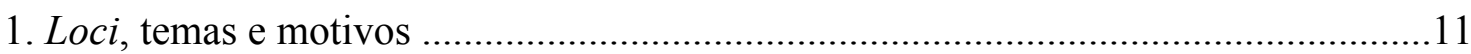

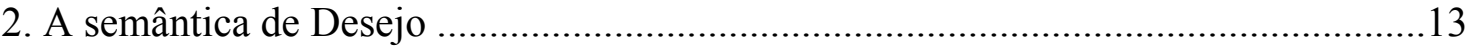

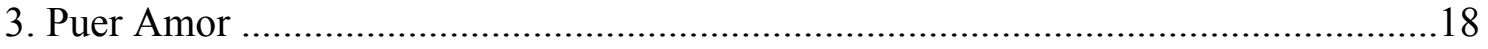

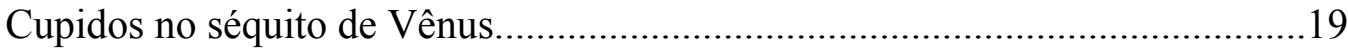

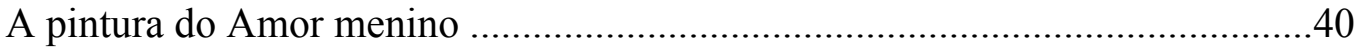

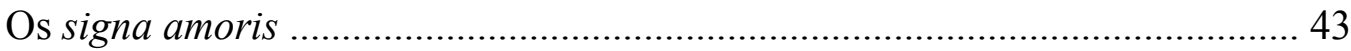

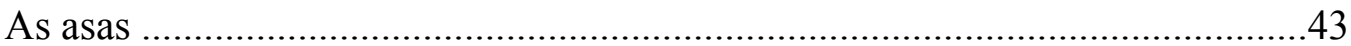

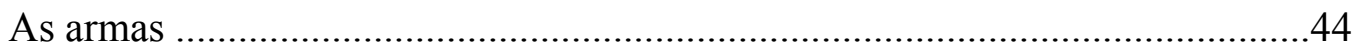

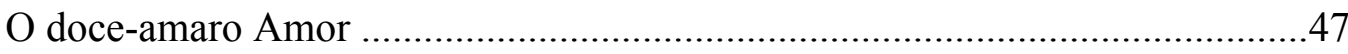

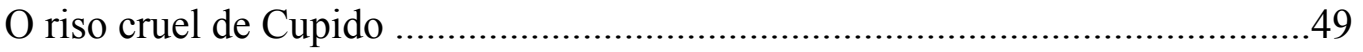

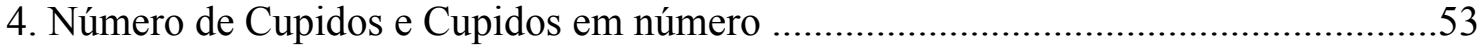

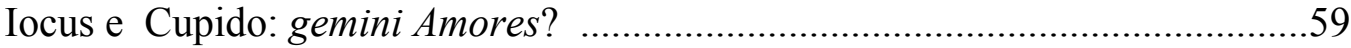

5. Papel de Cupido na conspiração épica de Vênus ...........................................................68

A ação de Amor na Eneida................................................................................68

Êthos: Amor assimila a figura de Ascânio .......................................................70

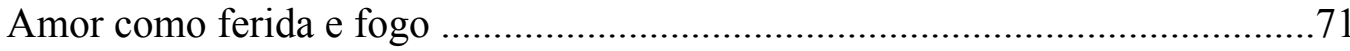

Páthos: as afecções desencadeadas por Amor ..................................................72

As transformações no êthos da rainha ..............................................................73

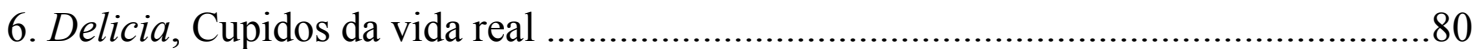

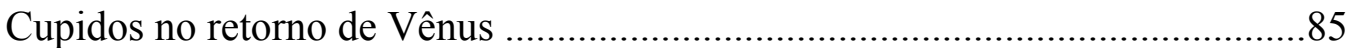

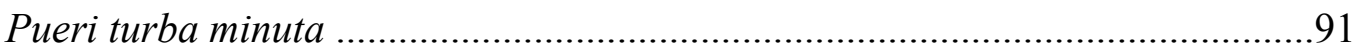

Cupido e o princípio da atração .....................................................................97

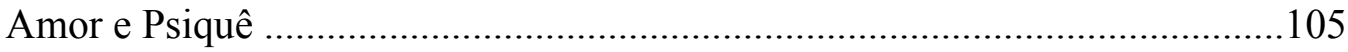

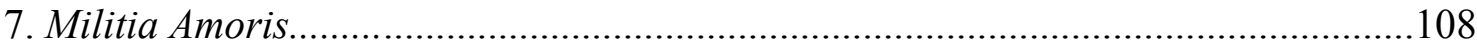

Marte, Vênus e Cupido: uma família de deuses do amor e da guerra em

Roma.

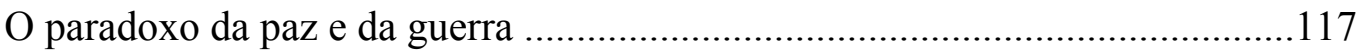

Um soldado ferido em seu próprio acampamento ..........................................120

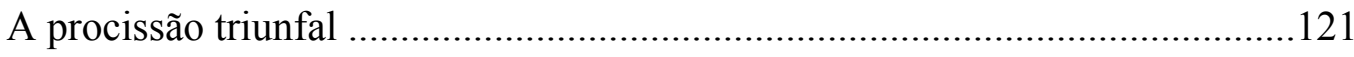

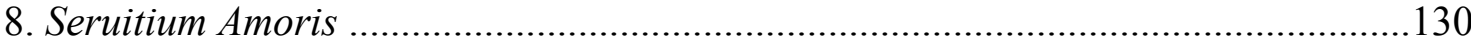


Amor como custos 131

Sob o jugo de Amor .134

Omnia uincit Amor 135

9. Nox, Amor et uinum 144

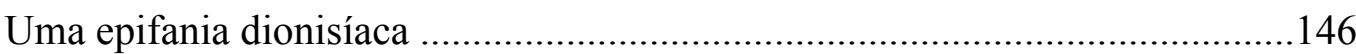

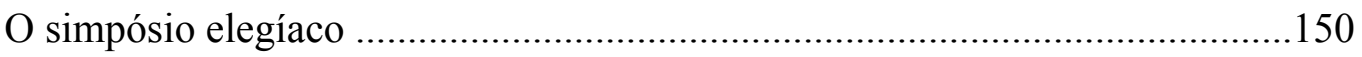

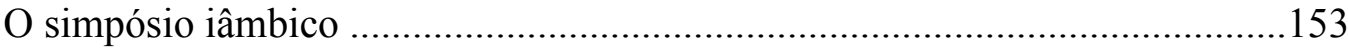

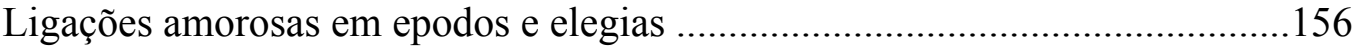

Os remedia amoris em epodos e elegias ......................................................158

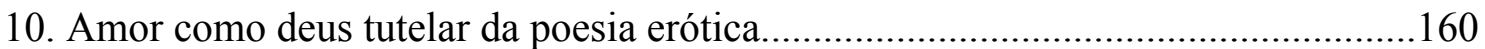

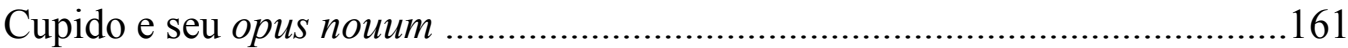

O certame entre Cupido e Apolo .................................................................. 164

O lascivo Amor no embate entre a Tragédia e a Elegia ....................................169

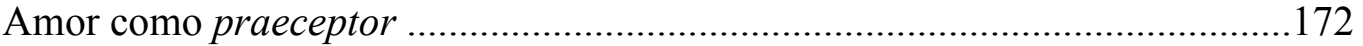

Uma genealogia de poetas de Amor ...........................................................182

Amor na memória e no esquecimento ..........................................................186

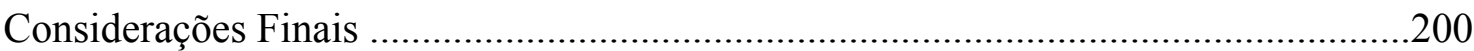

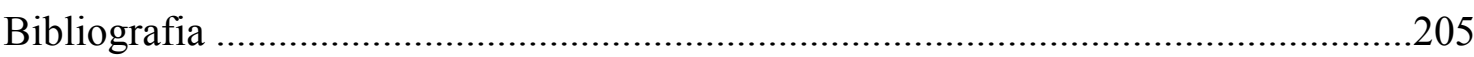




\section{INTRODUÇÃO}

O objetivo deste estudo é observar a presença do deus-personagem Amor em Roma entre o final da República e o Período Augustano ${ }^{1}$, com ênfase na poesia de Catulo $^{2}$, Virgílio ${ }^{3}$, Horácio ${ }^{4}$, Tibulo $^{5}$, Propércio $^{6}$ e Ovídio $^{7}$; abarcando passagens das seguintes obras: Livro de Catulo; Eneida, Éclogas e Geórgicas de Virgílio; Odes e Epodos de Horácio; Livros I e II de Tibulo; Livros I a III de Propércio; e Amores, Epístolas Ex Ponto, Metamorfoses, Heroides, Ars Amatoria, Remedia Amoris, Fastos e Tristia de Ovídio. De caráter interdisciplinar, o estudo propõe a observação das imagines Amoris em meios miméticos diversos, procedendo-se a busca por loci, temas e motivos análogos aos da poesia, em objetos de arte, como pinturas, esculturas, moedas e mosaicos, pertencentes ao período especificado, com a finalidade de realizar uma interpretação mais precisa das metáforas produzidas pelas imagens encontradas nos poemas.

Como suporte para o estudo das figurações de Amor nos poemas, o estudo irá se valer, também, de textos antigos que forneçam elementos para a discussão formal e de fundo, tanto em passagens que referenciem a figura do deus no mundo romano, como as que se encontram no De Natura Deorum de Cícero, História Natural de Plínio, o Velho; De Rerum Natura de Lucrécio e Descrição da Grécia (Periegesis Hellados) de Pausânias; bem como outras que ofereçam explicações sobre os mecanismos elocutivos e argumentativos que veiculam a personagem/deus nos poemas, como evidência, écfrase, descriptio, sermocinatio, alegoria, símile, metáfora e exemplum; mais especificamente aquelas encontradas na Epístola aos Pisões de Horácio; Livros VI a XII das Instituições Oratórias de Quintiliano; Orator, De Oratore e De Inuentione de Cícero; De Anima, Poética e Retórica de Aristóteles; e Retórica a Herênio (anônimo).

Para os romanos, Amor, também chamado de Puer ou Cupido, é o deus alado, armado com arco e flechas, tochas, correntes e outras armas, com as quais brinca, ferindo e aprisionando suas vítimas, que passam a manifestar os sintomas da paixão erótica. Normalmente ele age sob o comando da mãe, Vênus, a cujo séquito pertence. Sua figura, no mundo romano, é facilmente identificável e ao mesmo tempo complexa,

\footnotetext{
${ }^{1}$ séc. I a.C - I d.C..

284 a.C. -54 a.C..

3 70-19 a.C..

${ }^{4}$ 65-8 a.C.

5 54-19 a.C..

${ }^{6}$ 55-16 a.C..

${ }^{7} 43$ a.C.-18 d.C..
} 
apresentando uma variedade de genealogias, nomes e atributos, cujas referências se acumulam desde a Grécia Arcaica e somam-se a novos elementos nesse momento e lugar que é o foco de nossa investigação.

As traduções que não apresentarem crédito devem ser entendidas como próprias. São traduções instrumentais, que foram desempenhadas com atenção às especificidades genéricas e terminológicas do texto original, com a finalidade de buscar uma aproximação com a elocução do texto, evitando-se a projeção de conceitos modernos sobre o objeto antigo. 


\section{Loci, temas e motivos}

Considerando-se que o estudo contempla, além da poesia, a observação de imagens em artes diversas, que pressupõem meios distintos de imitação de caracteres, afetos e ações, ressalta-se que o principal ponto de contato entre elas a ser considerado nesta pesquisa refere-se aos loci da invenção empregados em sua composição. Não é raro encontrar homologias, em passagens de textos gregos e romanos antigos, que aproximam artes diversas como a oratória, a pintura e a escultura; afim de exemplificar a ação de imitar, bem como para estabelecer relações homólogas entre auctoritates. Aristóteles ${ }^{8}$, por exemplo, tece homologias entre a pintura e a poesia; Cícero, no início do segundo livro do De Inventione, estabelece relações entre retórica e pintura; Quintiliano, nas Instituições Oratórias $^{9}$, associa a oratória à pintura e à escultura. Simônides de Ceos aproxima a pintura da poesia com o aforismo: "a poesia é a pintura que fala, e a pintura é a poesia muda"; e Horácio diz "Vt pictura poesis" no conhecido verso 361 da Epístola aos Pisões. Tais homologias evidenciam a ideia do diálogo entre as artes presente no imaginário romano, que procuraremos explicitar ao longo da pesquisa.

No tocante à poesia, a pesquisa irá focalizar os loci, temas e motivos, evidenciando as caraterísticas físicas e anímicas do deus, seu modo de ação e suas relações. Uma vez que sua principal ação é ferir, desencadeando a afecção ou doença que o romanos chamam de amor, serão objeto de estudo algumas tópicas que moldam os éthe dos personagens envolvidos no iocus erótico, que aparecem em diferentes gêneros, como a lírica, elegia, bucólica e épica. Entre elas, a seruitium amoris e a militia amoris, que se referem, respectivamente, à submissão erótica, e ao paradoxo entre o universo bélico e o intercurso amoroso; e a renuntiatio amoris, que é a tentativa frustrada do amante de recusa do amor. Cupido figura também em poemas de recusatio, como deus que coage o poeta a negar a poesia elevada e o serviço militar em prol de uma vida de combate na milícia do amor e do sexo. Quanto às suas relações com outras divindades, ele é principalmente associado Vênus, Baco, Apolo e Marte. Vênus desempenha o papel de mãe e mentora de ardis contra deuses e mortais ${ }^{10}$, e, além de alma ou nutrix, é também victrix. Marte é apresentado como seu pai adotivo, formando, junto a Vênus, uma família de deuses do amor e da guerra. Baco figura ao seu lado em

\footnotetext{
${ }^{8}$ Arist., Po. 1148-1461.

${ }^{9}$ Quint., Inst. Or. 12.

${ }^{10}$ Cf Ov., Am. $1.2 ; 1.10 ; 1.6 ; 2.7 ; 2.9 . b ; 2.18 ; 3.1 ; 3.2 ; 3.9 ; 3.15$; Prop. $1.3 ; 1.14 ; 2.8 ; 3.16 ; 3.20 ; 4.1 \mathrm{~b}$; Tib. $1.3 ; 2.3 ; 2.4$.
} 
cenas de triunfo ${ }^{11}$ e de simpósio ${ }^{12}$. E com Apolo, Cupido se associa especialmente em poemas em que se destaca o seu papel como deus da poesia.

${ }^{11}$ Cf. Ov., Am. 1.2, 1.3, 3.15; Prop. 1.3; Tib. 1.4.

${ }^{12}$ Cf. Prop. 2.30.b. 


\section{A semântica de Desejo}

Cupido é apresentado nos textos como uma figura ambígua: o doce e belo, travesso e cruel jovem alado, que brinca de modo inconsequente com suas armas, com as quais perfura, golpeia, queima, aprisiona e domina. Ele carrega todos os atributos do afeto chamado de amor pelos romanos antigos, e age como vetor de afecções veementes desencadeadas em suas vítimas, que mergulham em um estado de euforia, insânia e furor, apresentando os signa amoris, que são alterações fisiológicas, como palidez, tremores, respiração ofegante; e afetos, como atração erótica incontrolável, inquietude, raiva, impotência, ressentimento, tristeza, ímpeto de vingança, medo, desdém ou despeito. Apesar ser apresentado como um cruel inimigo, por outro lado, ele oferece benefícios aos que visita, emprestando os seus dons, como a juventude, o vigor e a coragem. Favorecendo suas vítimas de um lado, e de outro privando-as de razão, ele consegue ludibriar até os deuses, induzindo-os cair sob o seu comando. Em suma, a paixão desencadeada por essa divindade é ao mesmo tempo um benefício e uma punição.

Nesse sentido, é oportuno lembrar a lição de Quintiliano a respeito do amor como afecção:

\section{Quin illud adhuc adicio, $\pi \dot{\alpha} \theta$ o $\varsigma$ atque $\tilde{\eta} \theta$ os esse interim ex eadem natura, ita ut illud maius sit, hoc minus, ut amor $\pi \dot{\alpha} \theta$ o $\varsigma$, caritas $\tilde{\eta} \theta \varsigma^{13}{ }^{13}$}

Antes, acrescento, ainda, que os afetos patéticos e éticos umas vezes têm a mesma natureza, e só se diferenciam no grau de força, isto é, ser a daqueles maior e a destes menor, como, por exemplo, o amor é um afeto patético, e a caridade um afeto ético. ${ }^{14}$

Os afetos éticos e patéticos diferenciam-se no grau de força. Estudaremos aqui o amor como afeto patético, veemente, do qual padecem os envolvidos nos jogos de Cupido. Observaremos a relação que se pode fazer entre o discurso, a palavra e a própria ação do deus.

Interessam, também, algumas questões semânticas referentes aos significados dos vários nomes do deus, às distinções entre esses nomes próprios e o uso comum nos poemas, e ao processo de pluralização, que será por onde iniciaremos a nossa discussão.

Para os poetas latinos três nomes podem referir-se ao amor personificado: Amor, Puer e Cupido, cuja frequência no uso varia também quanto ao número:

\footnotetext{
${ }^{13}$ Quint., Inst. Or. 4.2.12.

${ }^{14}$ Tradução de Jerônimo Soares Barbosa.
} 


\begin{tabular}{|c|c|c|c|c|c|}
\hline & & Amor (es) & Puer (i) & Cupido (ines) & Puer + Amor + Cupido \\
\hline \multicolumn{2}{|c|}{ Catulo } & 1 sing. & nihil & 5 (3 pl., 2sing.) & 6 \\
\hline \multicolumn{2}{|c|}{ Propércio } & $34 \mathrm{~s}$. & 11 (8 s., 3 pl.) & 2 (1 s., 1 pl.) & 47 \\
\hline \multirow{4}{*}{ Ovídio } & $\mathrm{Am}$. & $22(20$ s., 2 pl.) & 12 (11 s., 1 pl.) & $13 \mathrm{~s}$. & \multirow[t]{4}{*}{92} \\
\hline & Rem. & $10 \mathrm{~s}$. & $1 \mathrm{~s}$. & 4 (3 s., $1 \mathrm{pl})$ & \\
\hline & Ars & 11 (10 s., 1 pl.) & $1 \mathrm{~s}$. & 2s. & \\
\hline & Met. & $6 \mathrm{~s}$. & $1 \mathrm{~s}$. & $9 \mathrm{~s}$. & \\
\hline \multicolumn{2}{|c|}{ Tibulo } & $23 \mathrm{~s}$. & $16(15$ s., 1 pl. $)$ & $3 \mathrm{~s}$. & 42 \\
\hline \multirow[b]{2}{*}{ Virgílio } & $A$. & $3 \mathrm{~s}$. & $2 \mathrm{~s}$. & $4 \mathrm{~s}$. & \multirow[t]{2}{*}{13} \\
\hline & $\begin{array}{l}\text { Ecl. e } \\
\text { Georg. }\end{array}$ & $4 s$. & nihil & nihil & \\
\hline Horacio & $\begin{array}{l}\text { Carm. } \\
\text { Epod. }\end{array}$ & $2 \mathrm{~s}$. & $3 \mathrm{~s}$. & 5 (3 s., 2 pl.) & 10 \\
\hline \multicolumn{2}{|c|}{ Total: } & 115 & 47 & 47 & 210 \\
\hline
\end{tabular}

Tabela 1 - Ocorrências nominais de Amor, Puer e Cupido no corpus

Como podemos notar, na poesia latina é mais comum o uso do nome Amor no singular, especialmente entre os elegíacos. Segundo Wlosok ${ }^{15}$, este nome é o mais utilizado pelos poetas latinos desde Plauto. No entanto, em outros textos latinos, segundo este autor, que pesquisou outras fontes como Cícero, Plínio, o Velho e inscrições epigráficas, o nome Cupido é o mais frequente, especialmente em referência a estátuas e ao culto.

Por vezes, particularmente na poesia, é tênue a linha que separa o nome próprio do deus dos substantivos comuns amor, puer ou cupido. Nesse sentido, os manuscritos não facilitaram a vida dos editores dos textos latinos antigos, já que não há distinção entre maiúsculas e minúsculas, portanto, nesse caso, determinar qual uso está sendo feito da palavra, ou seja, se o poeta está ou não referindo-se ao deus, é uma decisão que cabe a cada pesquisador de acordo com o seu entendimento de cada passagem.

No De Inventione, Cícero define o amor como um impulso (impulsio), uma força (uis), uma afecção do ânimo (animi affectionis) ou perturbação mental (perturbatio animi):

Causa tribuitur in inpulsionem et in ratiocinationem. inpulsio est, quae sine cogitatione per quandam affectionem animi facere aliquid hortatur, ut amor, iracundia, aegritudo, vinolentia et omnino omnia, in quibus animus ita videtur affectus fuisse, ut rem perspicere cum consilio et cura non potuerit et id, quod fecit, impetu quodam animi potius quam cogitatione fecerit. ${ }^{16}$

A causa de um ato é atribuída ao impulso ou à premeditação. $\mathrm{O}$ impulso é aquilo que instiga alguém a fazer algo sem pensar, por causa de alguma afecção do ânimo, como o amor, a raiva, a aflição, embriaguez e, assim, todo estado em que o ânimo pareça ter sido afetado, de modo que não se consiga observar os atos com cuidado e prudência, e aquilo que se fez tenha sido movido por um ímpeto do ânimo e não pela reflexão.

\footnotetext{
${ }^{15}$ Wlosok (1975:175-176).

${ }^{16}$ Cic., De Inv. 2.17.
} 


\section{Ele elenca esse afeto como um locus de amplificação da argumentação retórica} no discurso jurídico, que pode ser usado como justificativa para um crime:

Hic locus sicut aliquod fundamentum est huius constitutionis. nam nihil factum esse cuiquam probatur, nisi aliquid, quare factum sit, ostenditur. Ergo accusator, cum inpulsione aliquid factum esse dicet, illum impetum et quandam commotionem animi affectionemque verbis et sententiis amplificare debebit et ostendere, quanta vis sit amoris, quanta animi perturbatio ex iracundia fiat aut ex aliqua causa earum, qua inpulsum aliquem id fecisse dicet. hic et exemplorum commemoratione, qui simili inpulsu aliquid commiserint, et similitudinum conlatione et ipsius animi affectionis explicatione curandum est, ut non mirum videatur, si quod ad facinus tali perturbatione commotus animus accesserit. ${ }^{17}$

Este tópos pode ser chamado de fundamento ou estado da questão, pois nenhum fato pode ser provado, sem que se apresente um motivo pelo qual o ato tenha sido praticado. Portanto, quando a acusação diz que algo foi feito por impulso, ela deverá necessariamente amplificar com palavras e expressões esse ímpeto, particularmente a agitação ou comoção do ânimo, e mostrar, quão grande força é o amor, quanta perturbação mental decorre da ira, ou de quaisquer outras causas pelas quais ele argumente que o acusado tenha sido levado a agir. Deve-se cuidar para que não pareça estranho que tal crime tenha sido cometido por alguém com o ânimo tomado por tal impulso. Isso pode ser feito mencionando-se exemplos daqueles que fizeram algo movidos por semelhante impulso, e traçando-se paralelos e explicando-se a natureza de tal distúrbio mental.

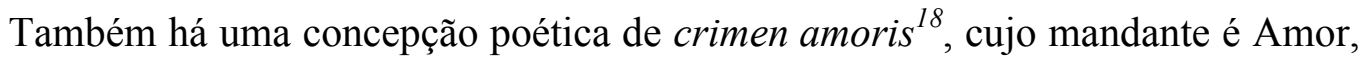
sobre o qual discutiremos em outra parte do trabalho.

No De Natura Deorum de Cícero, Cupido é definido como uis maior pelo personagem Balbo, cujo discurso baseado na filosofia estoica, oferece explicações e exemplos dessa e de outras personificações que dão forma a forças tão intensas que, segundo ele, foram divinizadas:

tum autem res ipsa, in qua vis inest maior aliqua, sic appellatur ut ea ipsa vis nominetur deus, ut Fides ut Mens, quas in Capitolio dedicatas videmus proxime a $\mathrm{M}$. Aemilio Scauro, ante autem ab $<$ A. $>$ Atilio Calatino erat Fides consecrata. vides Virtutis templum vides Honoris a M. Marcello renovatum, quod multis ante annis erat bello Ligustico a Q. Maxumo dedicatum. quid Opis quid Salutis quid Concordiae Libertatis Victoriae; quarum omnium rerum quia vis erat tanta ut sine deo regi non posset, ipsa res deorum nomen optinuit. quo ex genere Cupidinis et Voluptatis et Lubentinae Veneris vocabula consecrata sunt, vitiosarum rerum neque naturalium - quamquam Velleius aliter existimat, sed tamen ea ipsa vitia naturam vehementius saepe pulsant. Utilitatum igitur magnitudine constituti sunt ei di qui utilitates quasque gignebant, atque is quidem nominibus quae paulo ante dicta sunt quae vis sit in quoque declaratur deo. ${ }^{19}$

Por outro lado, a própria coisa na qual reside uma força de extrema potência é chamada de deus, como Fides e Mente, das quais vemos templos dedicados

\footnotetext{
${ }^{17}$ Cic., De Inv. 2.19-20.

${ }^{18}$ Cf. Prop. 2.30b.

${ }^{19}$ Cic., N. D. 2.61-62.
} 
recentemente no Capitólio por Marco Emílio Escauro, e, antes disso, Fides havia sido consagrada por Aulo Atílio Palatino. Tu vês o templo de Virtude, reformado como templo de Honra por Marcos Marcelo, porém muitos anos antes, durante a Guerra da Ligúria, havia sido dedicado por Quinto Máximo. O que dizer de $\mathrm{Ops}^{20}$, de Salvação, de Concórdia, de Liberdade, de Vitória? Todas essas coisas, das quais a força era tanta que não poderiam existir sem serem governadas por um deus, elas próprias receberam o nome de deuses. Pertencendo a esse mesmo gênero, os nomes de Cupido e Vênus Lubentina foram consagrados, coisas viciosas e antinaturais embora Veleio pense de outro modo. Todavia, todos esses vícios frequentemente abalam com maior veemência o nosso estado natural. Aqueles deuses, portanto, que trouxeram tantos benefícios, foram deificados de acordo com a grandeza desses benefícios, e os nomes que há pouco mencionei exprimem o poder que reside em cada desses deuses.

Segundo Calame ${ }^{21}$, um processo semelhante de deificação de um conceito abstrato deu forma à figura-conceito Eros na Grécia Antiga:

As we know, in ancient Greece love was essentially êros, a force that this term tended to objectivize as a power of such an autonomous nature that writing it with a capital E can be enough, in modern usage to express its divine nature. If Love was seen as an anthropomorphic deity, we should study it as a semiotic agent, with particular symbolic qualities and in consequence particular modes of meaning and action of its own, amid the forces that it brings into play...

A despeito das similaridades entre os deuses do amor romanos e gregos, vale lembrar a complexidade que envolve a variedade de nomes e número deles, tanto na Grécia como em Roma. Na Grécia Antiga há Eros, Pothos, Anteros e Himeros, enquanto em Roma, como já mencionado, há Cupido, Amor e Puer, como nomes que podem aparecer tanto no singular como no plural. Cada um desses nomes usados para o deus pode evocar diferentes circunstâncias e nuanças referentes à variedade de paixões despertadas por ele.

Platão ${ }^{22}$, por exemplo, distingue eros como o amor ativo, himeros como o desejo por objeto presente e pothos como desejo por objeto ausente. Calame ${ }^{23}$ discute as paixões associadas aos vários nomes do deus, considerando o seu campo semântico na poesia grega arcaica, em que, segundo ele, os termos pothos, himeros e erôs são muito próximos, com algumas variações, e são afetos que estão sempre subordinados aos desígnios de Afrodite. Personificados, Pothos e Eros possuem vários aspectos em comum: ambos são solta-membros ${ }^{24}$, se alojam nos olhos e instigam ao mais lânguido desejo não-correspondido por um jovem ou moça, cuja presença é suficiente para gelar

\footnotetext{
${ }^{20}$ Deusa que personifica a abundância.

${ }^{21}$ Calame (1999:14).

${ }^{22}$ Pl., Cra. 420.

${ }^{23}$ Calame (1999:30).

${ }^{24}$ Pothos solta-membros: Arquíloco, fr. 85; Eros solta-membros: Safo, fr. 130.
} 
um coração ardendo. Himeros é belo ${ }^{25}{\text { e } \text { ousado }^{26} \text {; enquanto Pothos é tempestuoso }}^{27}$ e ligeiro $^{28}$. Spencer ${ }^{29}$ considera que a palavra eros seja mais genérica do que himeros, porém ressalta que nem sempre essas distinções se mantêm, especialmente na poesia alexandrina, em que esses termos, por vezes, se tornam sinônimos. Ele observa que tampouco é direta a transposição do panteão de deuses do amor do mundo grego para o romano; e, nesse sentido, Eros não corresponde exclusivamente a Amor, nem Himeros a Cupido etc. Além disso, esses termos em grego apresentam, para os pesquisadores modernos, o mesmo problema de interpretação que possuem os termos latinos amor, puer e cupido, no que se refere à distinção entre nome próprio e substantivo comum, em determinadas passagens.

Breitenberger $^{30}$, que examina as diferentes facetas de Afrodite e Eros no mito e no culto na Grécia, observa que há vários outros elementos, além da etimologia, que, combinados, resultam em personificações deste tipo. Segundo ela, a invenção poética, começando com Hesíodo e Homero, teve papel fundamental no processo de transformação de conceitos abstratos em criaturas míticas. Tais poetas parecem ter como referência lendas, cultos e rituais que, ao serem integrados à poesia, sofrem adaptações aos diferentes gêneros. Conclui a autora que é difícil distinguir entre referências da tradição de culto ou mito e a invenção poética. Na poesia romana, além dos antecedentes da poesia grega, referências à etimologia, o culto e as lendas se entrecruzam nas figurações de Amor.

\footnotetext{
${ }^{25}$ Hes., Teog. 201.

${ }^{26}$ Meleagro, A. P. 7.421.

${ }^{27}$ Meleagro, A. P. 12.167.

${ }^{28}$ Filodemo, A. P. 10.21.

${ }^{29}$ Spencer (1932:121).

${ }^{30}$ Breitenberger (2007:67).
} 


\section{Puer Amor}

Para os romanos, Cupido é marcadamente caracterizado como um menino, Puer, cuja idade pode variar entre a de um bebê e a de um adolescente. Um dos principais elementos determinantes da sua identidade na poesia latina é a sua relação genealógica e hierárquica com Vênus, respectivamente como filho ${ }^{31}$ e integrante de seu séquito.

Uma das mais antigas referências aos deuses do amor na Grécia Arcaica encontra-se na Teogonia, em que Eros caracteriza-se como um dos deuses primordiais junto com Caos, Terra e Tártaro. Seu caráter paradoxal, que une extrema beleza física a uma tirania inigualável, encontrado na poesia latina, vem dessa época:

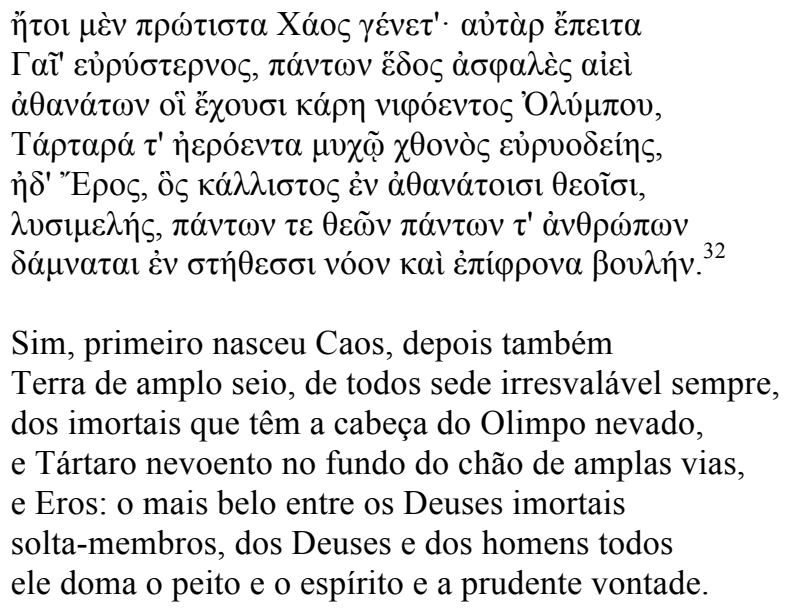

Segundo Giuliana Ragusa ${ }^{33}$, é rara a caracterização na Grécia Arcaica de Eros como menino ( $\pi \alpha \tilde{i} \varsigma$ ), que ganharia maior vigor posteriormente no mundo grego. Talvez

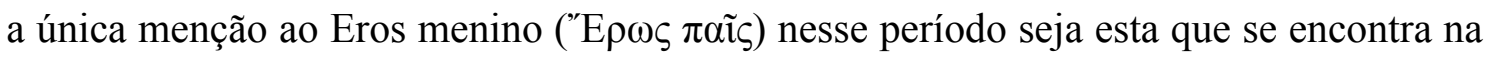
mélica de Álcman:

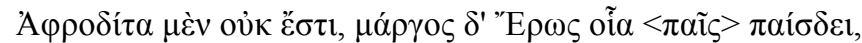

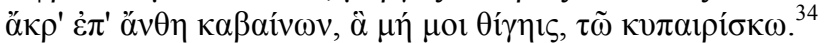

Afrodite não está, mas selvagem Eros que, qual $<$ menino $>$, brinca, a descer sobre o topo das flores - não me vás nelas tocar! - da galanguinha."35

\footnotetext{
${ }^{31}$ Cf. Mater Amorum: Ov., Ep. 7.59, 16.203; Am. 3.5.1.

${ }^{32}$ Hes., Teog. 116-122.

${ }^{33}$ Ragusa (2010:452).

${ }^{34}$ Frag. 58 Dav.

${ }^{35}$ Tradução de G. Ragusa (2010:440).
} 
Segundo Guerreri ${ }^{36}$ essa transformação do Eros adolescente, símbolo do ideal do eromenos, em criança, se inicia no período clássico, em que se fala menos da corte masculina que animava os simpósios, e começa-se a dar maior enfoque às cenas de matrimônio e da vida feminina. A ênfase na genealogia, que ganhou vigor ainda maior por volta do século III a.C. na Grécia, nas artes e na poesia, também se apresenta com forte presença no mundo romano do final da República.

$\mathrm{Na}$ poesia romana, o deus agrega dupla função: como membro do séquito de Afrodite, trabalha com suas armas para incentivar o amor; e como filho da deusa, iconiza o produto do amor ${ }^{37}$.

\section{Cupidos no séquito de Vênus}

Na Teogonia, Eros e Himeros aparecem como membros do séquito de Afrodite, cujos domínios incluem o amor, a juventude, os sorrisos e os enganos:

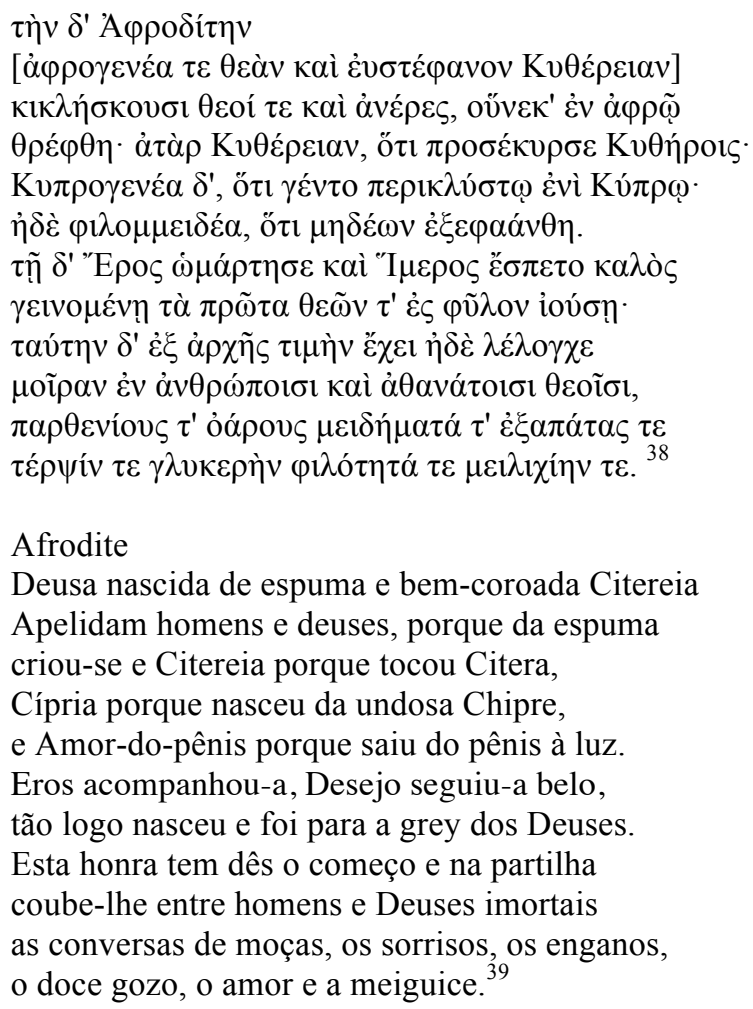

\footnotetext{
${ }^{36}$ Guerreri (2007:44).

${ }^{37}$ Agradeço ao professor William Fitzgerald por ter chamado atenção para o duplo papel do deus como incentivo e produto do amor.

${ }^{38}$ Hesíodo, Teog. 195-206.

${ }^{39}$ Tradução de Jaa Torrano.
} 
Himeros, além de pertencer ao séquito de Afrodite ao lado de Eros, figura também no séquito das Musas, acompanhado das Graças, presentes em festas com cantos e danças:

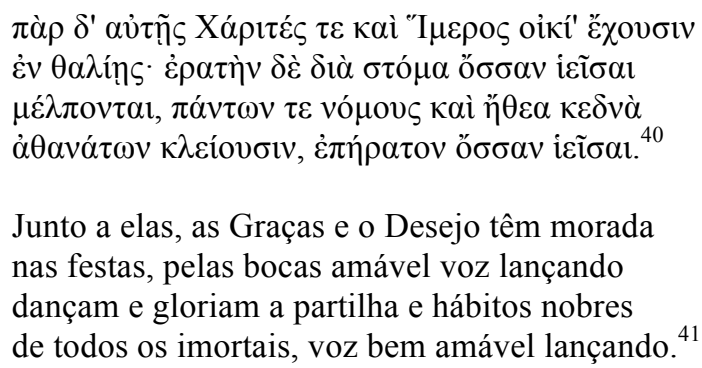

Jaa Torrano ${ }^{42}$ observa as relações de Himeros e Eros com as Musas na Teogonia, afirmando que a arte das Musas, não é a da persuasão, e sim da sedução, e, nesse contexto, Himeros aparece como produto daquilo que elas despertam, especialmente nas festas, onde seduzem com canto e danças. Eros, por sua vez, proporciona outro instrumento de sedução, manifestando-se na voz amável (eratèn óssan, v.65) das Musas, entre as quais uma chama-se Érato ${ }^{43}$.

A pintura abaixo é uma Vênus Anadyomene ${ }^{44}$, com o tema do nascimento da deusa acompanhada pelo séquito, composto por Eros e Himeros. O Puer da direita, montado em um golfinho, com cabelos encaracolados adornados com um diadema e uma clâmide pendendo ao redor do pescoço, porta o cetro de Vênus; seu corpo está quase totalmente fora da água, apenas a ponta dos dedos toca o mar. O segundo Puer, com cabelos curtos e sem cachos, posiciona-se atrás da concha, apenas com a parte superior do corpo aparente. Vênus, reclinada sobre a concha, está adornada com diadema nos cabelos, brincos, colar, pulseira e tornozeleiras, e envolta por uma clâmide que cobre o braço direito e esvoaça atrás de seu corpo, o que atribui movimento circular à figura:

\footnotetext{
${ }^{40}$ Hes., Teog. 64-67.

${ }^{41}$ Tradução de Jaa Torrano.

42 Torrano (2001: 33).

${ }^{43}$ Hes., Teog. 78.

${ }^{44}$ Cf. Papallardo (2009:154).
} 


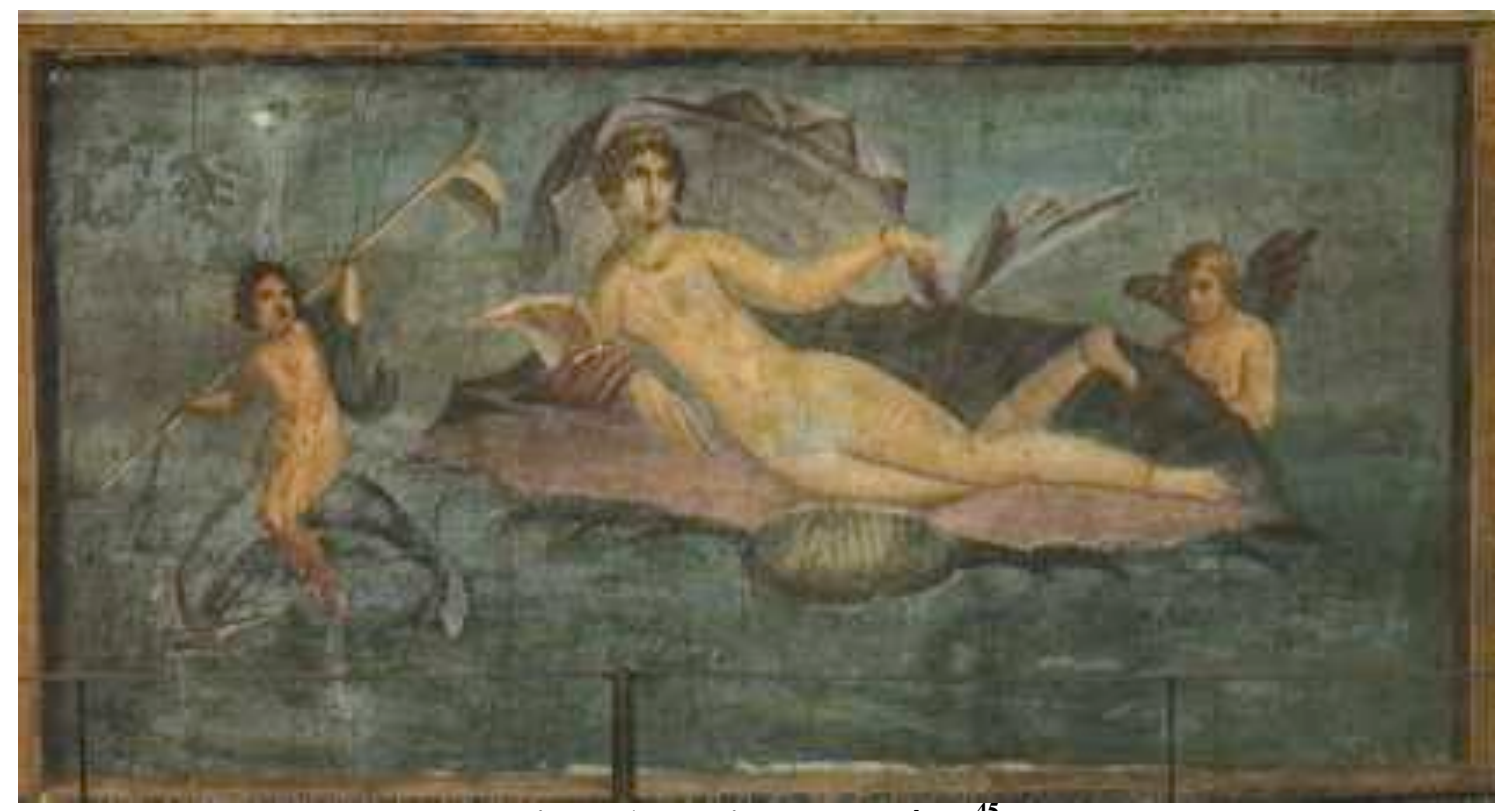

Figura 1. Nascimento de Vênus ${ }^{45}$

Há uma célebre obra de Apeles que é mencionada no texto de Plínio como "Vênus emergindo do mar", que teria sido exibida no Templo de Marte Ultor, construído por Augusto em homenagem a Júlio César:

\begin{abstract}
Venerem exeuntem e mari divus Augustus dicavit in delubro patris Caesaris, quae anadyomene vocatur, versibus Graecis $t a<n t>$ opere dum laudatur, $<$ aevis $>$ vict $<a>$, sed inlustrat $<a>$. cuius inferiorem partem corruptam qui reficeret non potuit reperiri, verum ipsa iniuria cessit in gloriam artificis. consenuit haec tabula carie, aliamque pro ea substituit Nero in principatu suo Dorothei manu. ${ }^{46}$

Divo Augusto dedicou a Vênus emergindo do mar [de Apeles], que era chamada Anadyomene, no templo do pai César; embora vencida pelos séculos, sendo muito elogiada em versos gregos, ela foi celebrizada. Tendo sua parte inferior se danificado, não foi possível encontrar quem a restaurasse; na verdade, o próprio dano veio a ser a glória do artífice. Esta pintura gastou-se com o tempo até apodrecer; e Nero, em seu principado, substituiu-a por outra feita pelas mãos de Doroteu.
\end{abstract}

A pintura parietal abaixo também apresenta elementos associados à figuração de Eros na função de membro do séquito de Afrodite. Sentada em seu trono e assistida por uma ama, a deusa, com vestes diáfanas e coroada com um diadema, incorpora a soberania e ao mesmo tempo a delicadeza, ao segurar uma flor. Eros, nu, de asas abertas e enfeitado com gemas no torso e nos braços, posiciona-se diante dela, e, assim como na figura anterior, segura o cetro, símbolo da autoridade da deusa:

\footnotetext{
${ }^{45}$ Nascimento de Vênus. Casa de Vênus Marinha, Pompeia. Peristilo. Afresco. 62 d.C..

${ }^{46}$ Plin., Nat., 35.91.
} 


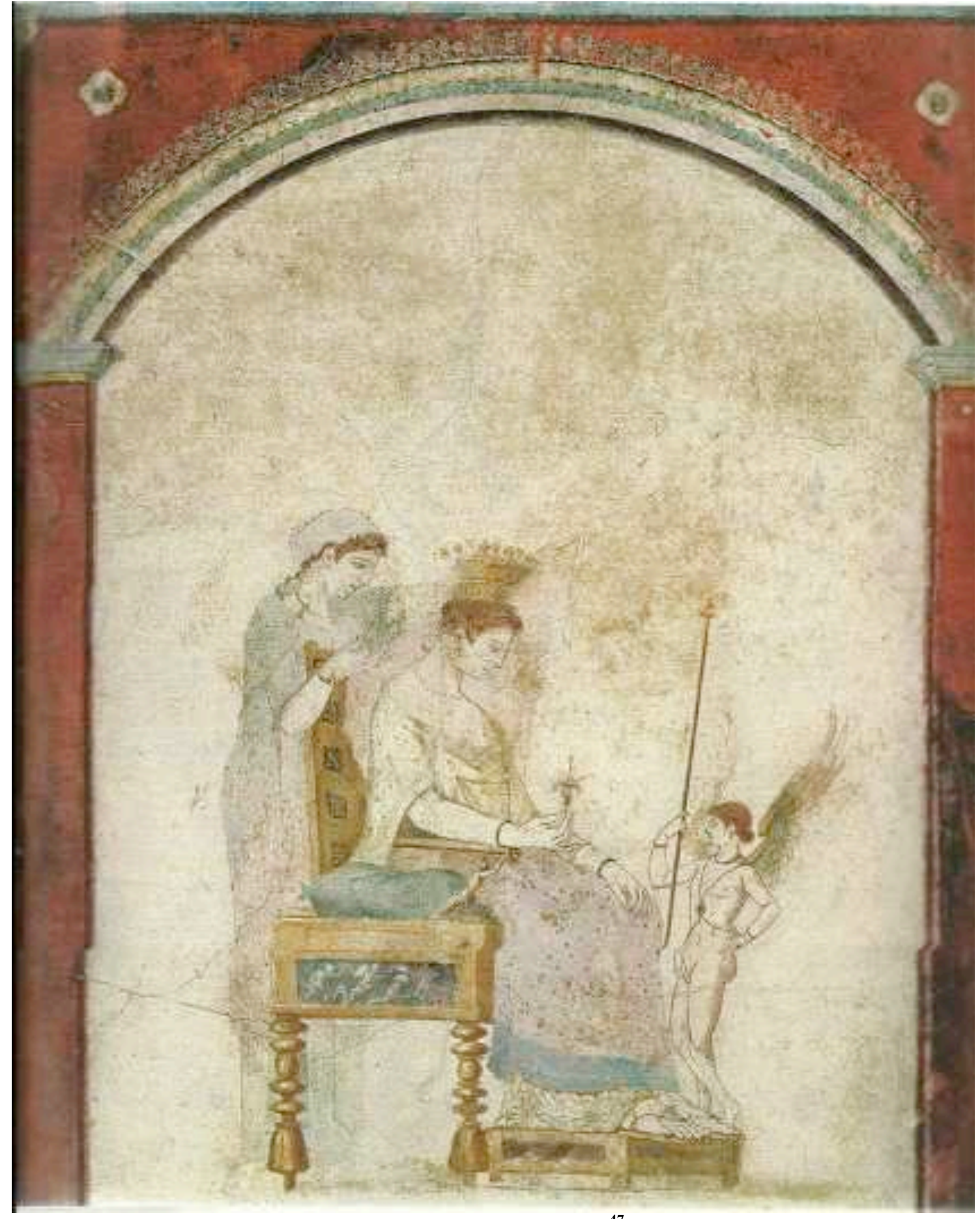

Figura 2. Vênus e Cupido ${ }^{47}$

Essa obra, de extremo refinamento, hoje exposta no Museu Nacional Romano, Palazzo Massimo, pertenceu a uma casa em Roma cuja propriedade é atribuída a Marcos Agripa, que a teria construído por volta de 21 a.C. para celebrar seu casamento com Júlia, filha de Augusto. Esse motivo, pintado em fundo branco no cubiculum B, é

\footnotetext{
${ }^{47}$ Museo Nazionale Romano, Palazzo Massimo. Villa Farnesina, Central Aedicule with Toilet of Aphrodite, left wall of Cubiculum B.
} 
de figuração que modernamente recebeu o nome de Neo-ática, porque os pesquisadores nela encontraram elementos que rementem a vasos gregos de fundo branco do século $\mathrm{V}$ a.C. ${ }^{48}$.

Giuliana Ragusa ${ }^{49}$ comenta sobre raras menções às genealogias de Eros na mélica arcaica, lembrando que Plutarco ${ }^{50}$ cita versos atribuídos a Alceu ${ }^{51}$, que dizem que Eros é filho de Íris e Zéfiro, nascendo, portanto, de uma relação genealógica que exclui Afrodite. Além de Alceu, escólios à Argonáutica ${ }^{52}$ de Apolônio e ao Idílio $13^{53}$ de Teócrito, citam conflitantes genealogias de Eros atribuídas a Safo, em que ele aparece como filho de Gaia e Urano, ou de Afrodite e Urano. Segundo Ragusa, na mélica, genealogias de Eros só aparecem nos poetas tardo-arcaicos, Simônides ${ }^{54} \mathrm{e}$ Baquílides $^{55}$.

Em epigramas eróticos helenísticos, a menção à genealogia que liga Eros a Afrodite é comum. Neste abaixo, de Meleagro ${ }^{56}$, evidencia-se essa relação, em que se contrastam a água e o fogo como aspectos da natureza, respectivamente, da mãe e do filho:

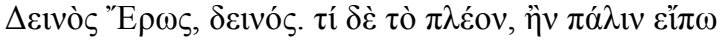

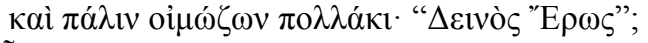

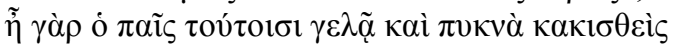

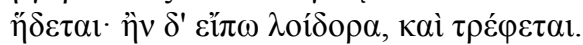

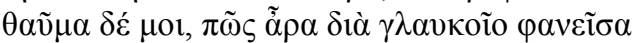

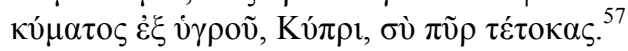 \\ Terrível Eros, terrível! De que me serve de novo \\ e de novo dizer, cheio de lamúrias: terrível Eros? \\ Sim, disso o menino ri e se deleita quando insultado, \\ mas se o ultrajo, ele se infla ainda mais. \\ É-me assombroso, Cípris, como, nascida \\ da glauca vaga do mar, deste à luz o fogo! ${ }^{58}$
}

Como dissemos, os poetas latinos dão ênfase tanto à relação hierárquica como à genealógica entre Vênus e Cupido. Nas Odes de Horácio, ele aparece sempre associado

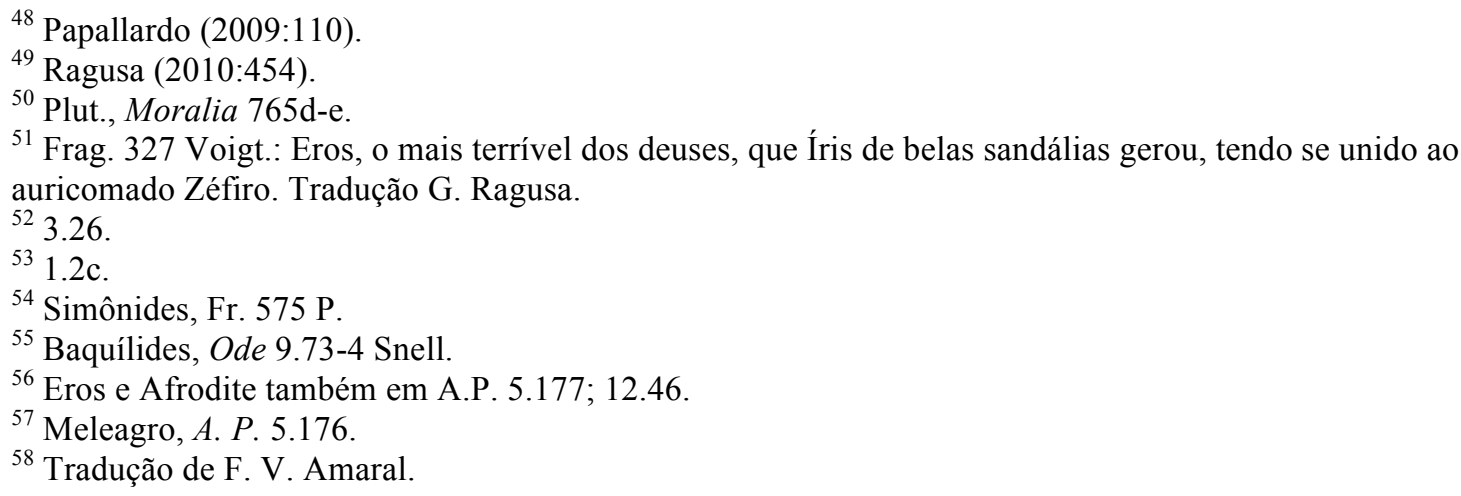


a ela ${ }^{59}$, seja voando ${ }^{60}$, ou tomando parte em ardis contra deuses e mortais ${ }^{61}$, ou atendendo súplicas, como nesta ode abaixo, em que ele se inclui no séquito de Vênus, a que pertencem também as Graças, Juventude e Mercúrio:

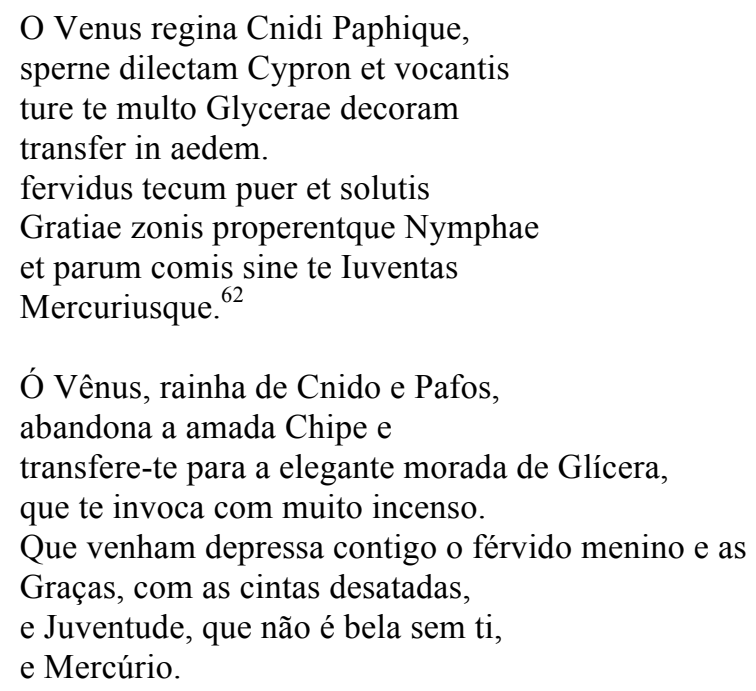

Esta breve e epigramática ode consiste em um apelo ou prece para obtenção do favor de Vênus. A deusa é invocada para abandonar seu santuário e mudar-se para a elegante morada ${ }^{63}$ de Glícera, e com ela todo o seu séquito. Nisbet e Hubbard observam que este poema possui uma "ancestralidade" complicada, indicando possíveis protótipos: o frag. 55 de Álcman, os fragmentos 1 e 2 de Safo e um epigrama de Possídipo de Pella ${ }^{64}$, sendo este último, de acordo com Mayer, claramente paródico da lírica arcaica. Com o frag. 1 de Safo, a semelhança está na invocação a Vênus por meio de uma prece pessoal por ajuda. O convite para a deusa fixar residência em um templo segue a formula de muitos hinos públicos, como, por exemplo, o frag. 2 de Safo. Segundo Cairns ${ }^{65}$, essa junção de elementos de dois tipos de hinos, um público e outro privado, provavelmente tem por fim chocar e divertir os leitores. Essa euocatio lembra uma prática romana de invocar deuses estrangeiros para abandonar o lugar de origem e fixar residência em Roma, para, assim, favorecer a conquista de determinado território.

Observemos mais detalhadamente as divindades que tomam parte nesse cortejo, especialmente Cupido, que é o primeiro membro do séquito a ser mencionado, sendo

\footnotetext{
${ }^{59}$ Hor., Carm. 1.32.11: semper haeretem puerum.

${ }^{60}$ Hor., Carm. 1.2.34: circum uolat.

${ }^{61}$ Hor., Carm. 3.12.4 e 3.27.67-8.

${ }^{62}$ Hor., Carm. 1.30.

${ }^{63}$ A palavra aedes está no singular, e poderia ser traduzida como templo, ou então, como sugere Mayer (2012:155), um sacrarium em uma casa, como o que Paulo Máximo constrói para Vênus em Odes 4.1.

${ }^{64}$ Possídipo de Pella, A. P. 12.131.

${ }^{65}$ Cairns (1971:445-446).
} 
identificado como feruidus puer: puer no sentido de que ele é um menino, filho de Vênus; e feruidus, de acordo com Quinn ${ }^{66}$, talvez por causa do zelo com que ele auxilia sua mãe, mas especialmente devido ao seu inerente poder de destruição, na metáfora do amor como fogo, que se traduz na luxúria incontrolável que assola os que são atingidos pelo deus.

Em Odes 1.30, paira uma dúvida sobre quem estaria endereçando a invocação a Vênus, podendo ser Horácio ou Glícera. David Trail ${ }^{67}$ sugere que seja Glícera. Ele a equipara à persona de Barine como uma prostituta em idade madura ${ }^{68}$, que estaria invocando, não apenas o tradicional séquito de Vênus com Cupido e as Ninfas, mas também Juventude, para recuperar a beleza, e até mesmo Mercúrio, o patrono das transações comerciais, para ajudá-la a reerguer o seu negócio; o que atribuiria certo tom cômico ao poema. David West ${ }^{69}$ oferece uma interpretação diversa, dizendo que é Horácio quem estaria invocando Vênus e seu séquito para auxiliá-lo a conquistar Glícera. Embora ele admita a importância dos hinos religiosos na concepção desse poema, ele discorda dos comentadores sobre algumas fontes. Ele também tende a descartar a interpretação satírica, alegando certa superficialidade, pois estaria em desarmonia com as figuras presentes no poema. Para ele, os integrantes do séquito são como uma alegoria para o modo como o poeta deseja que Vênus visite Glícera: Mercúrio não foi chamado para auxiliar financeiramente, mas para ajudar o poeta na sedução, já que esse é o deus de Horácio, e por isso o favoreceria; Cupido faria com que Glícera ardesse por ele e as Graças e as Ninfas despertariam nela o desejo e a desinibição; ao passo que Juventude traria de volta a ele o vigor de outros tempos. Em suma, as divindades moldariam e adequariam uma situação propícia para o poeta: Glícera apaixonada, desinibida, graciosa e radiante, e ele com novas forças para seduzir sua amada.

Se considerarmos a interpretação de West, teremos que importar essa relação de Odes 1.19, em que Horácio é atingido com toda força:

\footnotetext{
Mater saeva Cupidinum

Thebanaeque iubet me Semelae puer

et lasciva Licentia

finitis animum reddere amoribus.

urit me Glycerae nitor
}

\footnotetext{
${ }^{66}$ Quinn (2002:180).

${ }^{67}$ Trail (1993).

${ }^{68} \mathrm{O}$ motivo da cortesã ou amante envelhecido, recorre frequentemente, tanto nas Odes, em 1.25 (com Lídia), 4.13 (com Lice) e 4.10 (com Ligurino), como nos Epodos, mais especificamente o 8 e o 12.

${ }^{69}$ West (1995:142-145).
} 
splendentis Pario marmore purius, urit grata protervitas

et voltus nimium lubricus adspici.

in me tota ruens Venus

Cyprum deseruit nec patitur Scythas

et versis animosum equis

Parthum dicere nec quae nihil attinent.

hic vivum mihi caespitem, hic

verbenas, pueri, ponite turaque

bimi cum patera meri:

mactata veniet lenior hostia. ${ }^{70}$

A mãe cruel dos Cupidos,

o filho de Sêmele Tebana

e a lasciva Licença ordenam-me

a trazer de volta ao peito amores do passado.

O brilho de Glícera me queima,

mais resplandecente que o mármore pário mais puro,

Queima-me seu delicioso atrevimento,

sua face é resplandecente demais para ser vista.

Vênus desertou Chipre e lança-se sobre mim com toda força.

Ela não admitirá versos sobre citas,

nem sobre impetuosos cavaleiros persas

em recuo, e nada que seja irrelevante.

"Ponde aqui, meninos, ramos de ervas frescas e verbenas, e incenso

com taça de vinho puro de dois anos:

honrado o sacrifício, ela virá mais branda".

Para aplacar os deuses do amor e do vinho, o poeta oferece incenso, ervas sagradas, vinho e uma vítima, pois estariam atribulando sua vida do poeta, fazendo-o queimar de amor por Glícera. A relação entre os deuses e mortais em Odes 1.19 e 1.30 se inverte: na 1.19, Glícera parece contar com o favor desses deuses e Horácio é atingido com tanta força que precisa acender incenso e oferecer sacrifício para aplacar a violenta investida, enquanto na 1.30, é necessário queimar incenso para ganhar o favor desses deuses, independentemente de quem esteja procedendo a invocação.

Cupido aparece associado ao tópos do amor como fogo em outras Odes de Horácio, como esta abaixo, na qual novamente o menino integra o séquito de Vênus com as Ninfas. Ele é um aliado nas conquistas de Barine, uma cortesã que, embora madura, consegue manter-se bela e vigorosa, atraindo o favor do deus, que afia incessantemente suas setas ardentes em uma pedra ensanguentada. A metáfora do fogo, desta vez, se transfere para as armas, que, com a força atrito sobre a pedra, se aquecem ainda mais:

Vlla si iuris tibi peierati poena, Barine, nocuisset umquam, dente si nigro fieres vel uno turpior ungui,

\footnotetext{
${ }^{70}$ Hor., Carm. 1.19.1-16.
} 
crederem: sed tu simul obligasti perfidum votis caput, enitescis pulchrior multo iuvenumque prodis publica cura.

expedit matris cineres opertos fallere et toto taciturna noctis signa cum caelo gelidaque divos morte carentis.

ridet hoc, inquam, Venus ipsa, rident simplices Nymphae ferus et Cupido semper ardentis acuens sagitas cote cruenta.

adde quod pubes tibi crescit omnis, servitus crescit nova nec priores inpiae tectum dominae relinquunt saepe minati.

te suis matres metuunt iuvencis, te senes parci miseraeque nuper virgines nuptae, tua ne retardet aura maritos.

Se, algum dia, tivesses sofrido uma punição por perjúrio, Barine,

se, por dente negro,

ou por uma unha, tivesses ficado menos formosa, eu acreditaria em ti:

mas logo após teres jurado por tua cabeça pérfida, tu começas a brilhar ainda mais bela,

e surges como preocupação pública da juventude.

É vantajoso para ti jurar em falso pelas cinzas sepultadas da mãe,

pelas constelações com todo o firmamento no silêncio da noite, e pelos deuses que são isentos da gélida morte.

Ri disto, eu digo, a própria Vênus, riem as singelas Ninfas e o fero Cupido,

que está sempre afiando suas setas ardentes em pedra ensanguentada.

Além disso, toda uma nova geração de jovens cresce, cresce para te servir,

enquanto os predecessores não abandonam a casa da ímpia senhora, apesar das frequentes ameaças. As matronas temem a ti pelos seus meninos, os velhos avarentos também, e as infelizes noivas virgens, ao pensar que teu esplendor vá deter os seus maridos.

Ancona $^{72}$ observa que Cupido é um deus quente (feruidus), assim como suas armas, e não frio como os deuses geralmente são; e seu poder de despertar o calor da paixão o aproxima dos humanos. Ele está sempre afiando suas setas, o que é uma metáfora para a constante ameaça de Barine, a quem ele favorece, atingindo a juventude. O calor das flechadas torna-se motivo de diversão para Vênus e seu séquito,

\footnotetext{
${ }^{71}$ Hor., Carm. 2.8.1-16.

72 Ancona (1994:80).
} 
que veem crescer o desejo mental e físico dos jovens, para o deleite de Barine, e desespero das matronas romanas.

Em todos esses exemplos do papel de Cupido no séquito de Vênus, percebemos que o fogo é um instrumento fundamental para a condução dos assuntos presididos pela deusa, que conforme encontramos na Teogonia são: o amor, os ardis, a juventude e o vinho.

Modelos de Afrodite atribuídos a escultores gregos célebres aparecem acompanhadas por Cupidos em esculturas romanas, como esta, abaixo, datada do Período Imperial. Estudiosos estimam que composições como esta estejam em circulação em Roma desde o século II a.C. Segundo Pafumi ${ }^{73}$, não é possível estabelecer com certeza o limite cronológico da tradição copística desse tipo de estátua, mas provavelmente elas começaram a circular no território romano primeiramente no oriente por volta do período tardo-helenístico, e depois no ocidente por volta do período augustano:

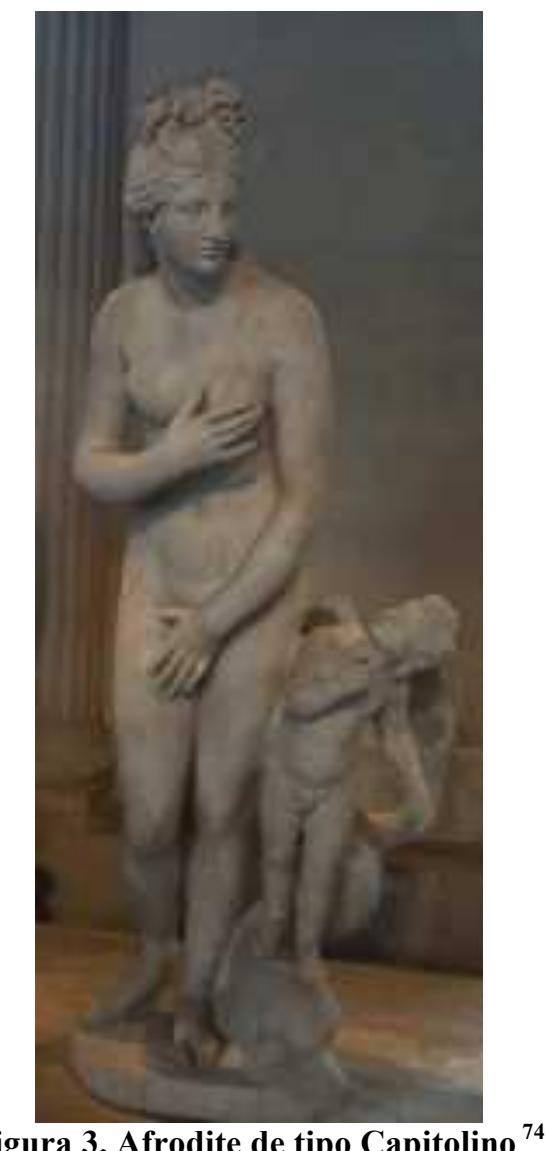

\footnotetext{
${ }^{73}$ Pafumi (2009:110).

${ }^{74}$ Louvre. Aphrodite of the "Capitoline" type. Inventaire MR 369. Roman, Imperial (2nd century AD). Provenance: Rome. Marble: H. 1.80 m. This figure of "Aphrodite", the most famous ancient copy of
} 
No Museu de Nápoles, há outras variantes dessa composição: um gracioso Eros menino combina-se com um modelo de Vênus ao banho ${ }^{75}$, que Plínio ${ }^{76}$ atribui ao bitínio Daedalsas, do séc. III a.C..

Certos motivos, como o golfinho, que aparecem em estátuas de Afrodite e Eros juntos como as que vimos acima, também aparecem sem a presença da deusa, somente com Cupido, como neste exemplar abaixo, usado como adorno de fonte:

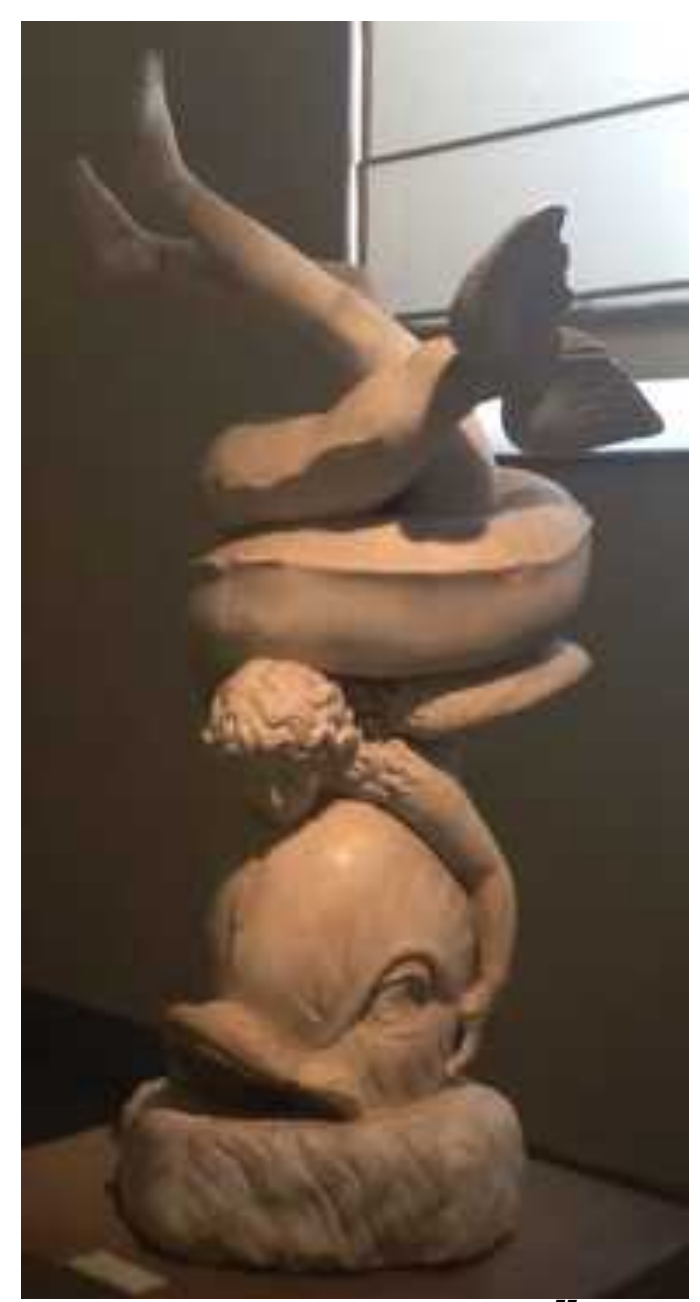

Figura 4. Eros com Golfinho ${ }^{77}$

which is in the Capitoline Museum in Rome, derives from the "Aphrodite of Cnidus" created by Praxiteles in the 4th century BC. The lost Greek statue from Asia Minor on which the "Capitoline Venus" is thought to be based probably dated from the 3rd or 2nd century BC and modified the Praxitelian tradition by a more voluptuous treatment of the flesh and by the gesture of modesty with which the goddess covers herself with both hands when surprised while bathing. The Eros and the dolphin were probably added by the copyist. Former Borghese collection. Department of Greek, Etruscan, and Roman Antiquities.

${ }^{75}$ Pafumi (2009:69-71).

${ }^{76}$ Plin., Nat. 36.35 
Segundo Pafumi ${ }^{78}$, o motivo de Eros montando em um golfinho pode ser encontrado na arte grega a partir da metade do século IV a.C.. Esta autora ${ }^{79}$ considera plausível a hipótese de que esse adorno de fonte, do século II d.C., tenha resultado de uma tentativa do copista de isolar um elemento que normalmente vinha acompanhado da figuração de Afrodite. Esse motivo marcou forte presença nas artes em Roma, sendo amplamente reproduzido também em artes como a numismática, por exemplo, nesta moeda datada do governo de Júlio César:
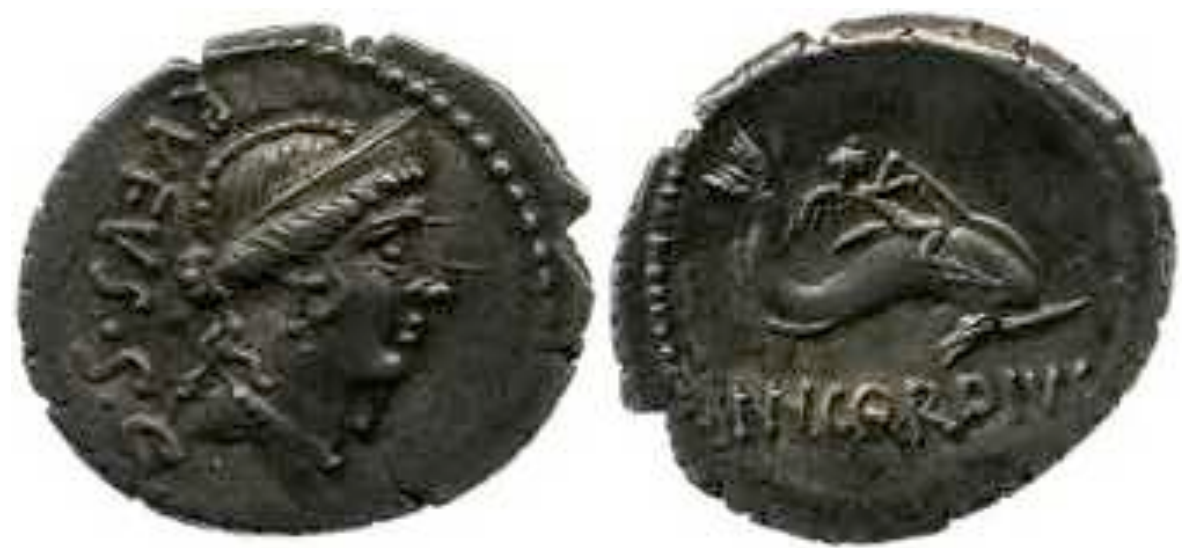

Figura 5. Cupido montado em um golfinho ${ }^{80}$

As moedas tinham um papel importante na circulação pelo território romano de imagens de monumentos e outros objetos cívicos ou sagrados para os romanos, ampliando a transmissão de metáforas a elas inerentes ao maior número de pessoas possível. Esta, acima, lembra menos a Vênus que cuida dos assuntos do amor pessoal, e mais a Victrix, que é honrada com templos e celebrações a cada grande vitória militar dos romanos. Porém é difícil mesurar até que ponto essas duas faces podem ser

\footnotetext{
${ }^{77}$ Museo Archeologico Nazionale di Napoli. Grupo di Eros com delfino. Inv. 6375. Materia: Marmo bianco a grana fine. Misure: Alt. M. 1,64. Datazione: puo essere fissata su basi stilistiche verso al fine del II secolo d.C.

${ }^{78}$ Pafumi (2009:92).

${ }^{79}$ Pafumi (2009:92)

${ }^{80}$ The British Museum. Department: Coins \& Medals. Registration number: 2002,0102.4576. Bibliographic reference: Ghey, Leins \& Crawford 2010 463.3.5. RRC 463/3 (type). Coin. Denomination: denarius. Materials: silver. Production place: Minted in Rome. Date: 46 B.C. Period/Culture: Roman Republican. Authority: Moneyer Mn Cordius Rufus. State: Roman Republic. Description: Silver coin. (obverse) Head of Venus right, wearing diadem; behind, inscription. Border of dots. (reverse) Cupid on dolphin right; below, inscription. Border of dots.

Inscriptions: Inscription Type: inscription. Inscription Position: reverse. Inscription Language: Latin. Inscription Content: MN·CORDIVS. Inscription Comment: MN ligatured. Inscription Type: inscription. Inscription Position: obverse. Inscription Language: Latin. Inscription Content: RVFVS·S·C. Inscription Comment: downwards. Dimensions: Weight: 4.03 grammes. Die-axis: 1 o'clock.
} 
separadas. A imagem da moeda possivelmente reproduziria algum objeto exposto em um templo dedicado à deusa, entre os quais espólios de guerra, como pinturas e esculturas célebres, que, por sua origem e história, assimilaram a qualidade de ícone do poder e da riqueza dos romanos.

A estátua de bronze, abaixo, que faz parte do acervo do MET, foi um dos modelos helenísticos de Eros criança mais reproduzidos em Roma ${ }^{81}$. A figura é graciosa nos detalhes das asinhas em repouso e dos cabelos encaracolados, e é tão precisa nos contornos dos músculos e na expressão facial, que o pequeno parece até respirar tranquilamente em sono profundo:

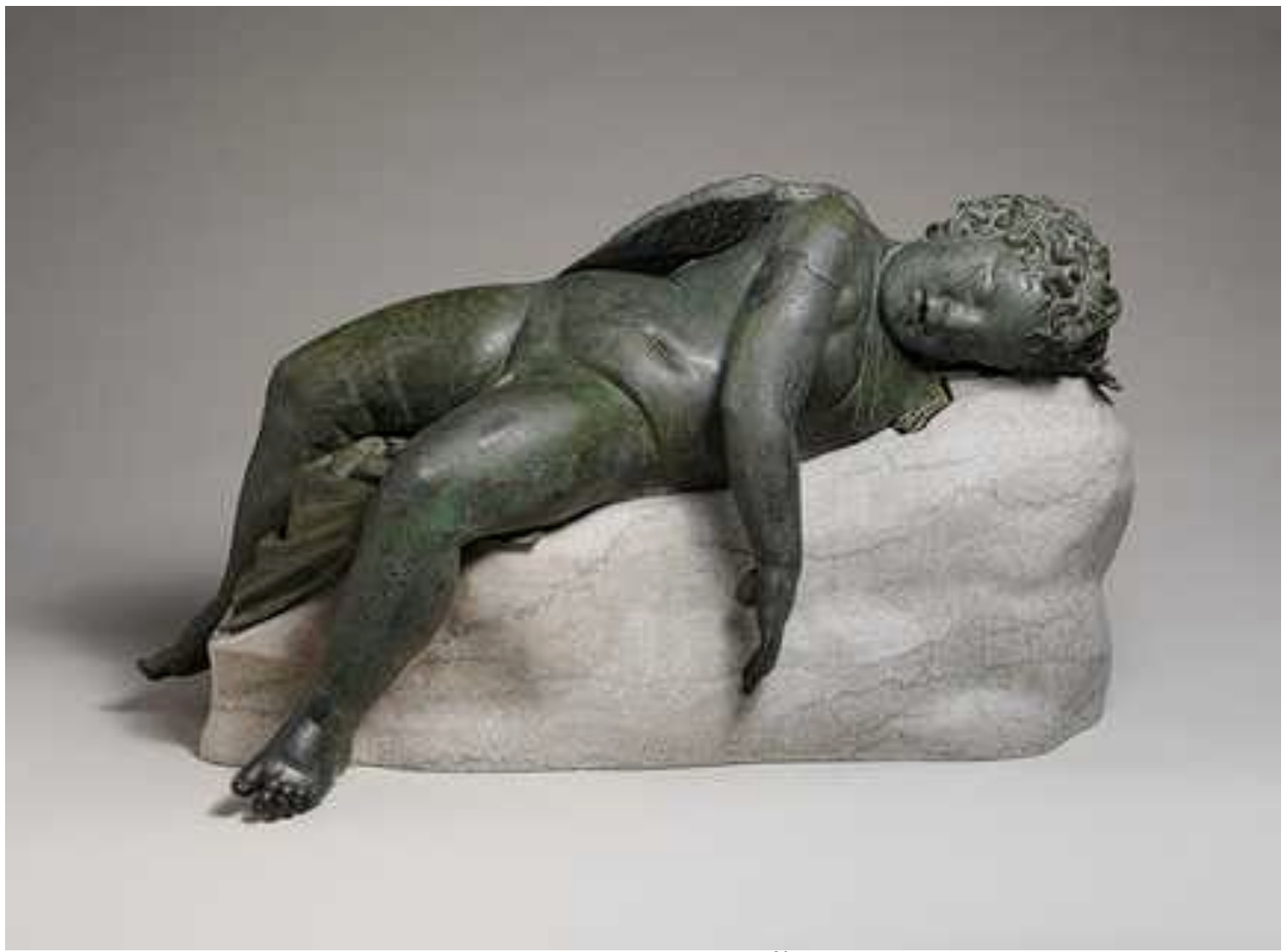

Figura 6. Sleeping $\operatorname{Eros}^{82}$

\footnotetext{
${ }^{81}$ Richter (1943:372).

82 Metropolitan Museum of Art, New York. Statue of Eros sleeping, 3rd-2nd century B.C.; Accession number: 43.11.4. Hellenistic Greek. Bronze; L. 33 9/16 in. $(85.24 \mathrm{~cm})$. Rogers Fund, 1943. One of the few bronze statues to have survived from antiquity, this figure of a plump baby conveys a sense of the immediacy and naturalistic detail that the medium of bronze made possible. This statue is the finest example of its kind. Judging from numerous extant replicas, the type was popular in Hellenistic and Roman times. Its high quality and large scale are most appropriate to a religious sculpture, one that was likely dedicated at a sanctuary to Eros or his mother, Aphrodite. In later times, the statue may have remained in its original location or been moved as a valuable antique Greek sculpture and displayed in a private setting such as a Roman villa. Differences in the metal alloy of the drapery between the legs as well as its technique of manufacture suggest that this part of the statue was restored at a later date, perhaps during the Early Imperial period.
} 
Dois aspectos dessa estátua eram favoritos no mundo helenístico: a figuração de crianças e a posição corporal deitada ${ }^{83}$. Segundo Richter ${ }^{84}$, esse bronze foi encontrado em Rodes, mas não é necessariamente um produto da arte local, já que a cidade era um grande centro comercial e ponto de concentração de artífices das mais diversas origens. A autora estima que esta imagem de alta qualidade tenha tido função religiosa na Grécia, e quando trazida para Roma é provável que tenha passado a pertencer a uma coleção particular. Modelos semelhantes a este multiplicaram-se, especialmente em mármore, por todo o território romano, por longo tempo, entre os quais há uma cópia muito semelhante do século II d.C., que encontra-se hoje no Museu Capitolino, Palazzo Clementino, em Roma. Esta concepção de Eros dormindo é contrastante com a do cruel, ativo e poderoso menino alado que atira suas setas incansavelmente; nela evidencia-se a face dócil do deus, que, embora esteja portando a aljava, descansa com a aparência plácida da mais pura inocência.

O Eros adormecido pode variar em poses e atributos, como arco, aljava ou tocha. Outra variante romana desse tipo está no Museu de Nápoles ${ }^{85}$ : ele está sentado em uma rocha, com a testa reclinada sobre as mãos, que se apoiam sobre joelho esquerdo flexionado. Embora a estátua de Rodes possivelmente tenha pertencido a um contexto religioso na Grécia, em Roma, as réplicas em mármore provavelmente tiveram outros usos, principalmente decorativo, funerário e votivo. Dependendo do contexto, este motivo poderia também figurar como Hypnos ou Thanatos, o deus da morte, que tem como atributo a tocha invertida e as pernas cruzadas, comum em sarcófagos.

Epigramas helenísticos também lançam mão da metáfora de Eros adormecido, como este de Meleagro, que evidencia o caráter dúbio e dissimulado do deus, que mesmo repousando de modo irresistivelmente doce no colo da mãe, permanece o mesmo menino arrogante, esnobe, escarnecedor, cruel e selvagem:

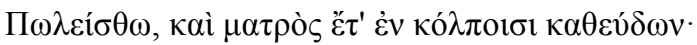

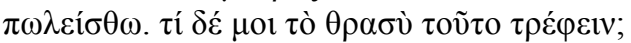

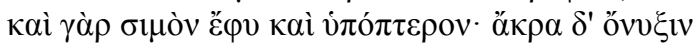

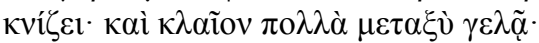

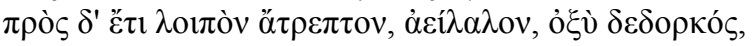

\footnotetext{
83 "Statue of Eros sleeping [Greek] (43.11.4)". In: Heilbrunn Timeline of Art History. New York: The Metropolitan Museum of Art, 2000-. http://www.metmuseum.org/toah/works-of-art/43.11.4 (April 2007) ${ }^{84}$ Richter (1943:374).

${ }^{85}$ Museo Archeologico Nazionale di Napoli. Statua di Eros addormentato. Inv. 6339. Materia: Marmo bianco a grana fine con striature grigiastre. Misure: Alt.: $\mathrm{m} \mathrm{0,63.} \mathrm{Um} \mathrm{fanciullo} \mathrm{alato,} \mathrm{nudo,} \mathrm{siede} \mathrm{su} \mathrm{un}$ rialzo riccioso sul quale flettendo il ginocchio flesso sostiene la testa reclinata nel sonno.
} 


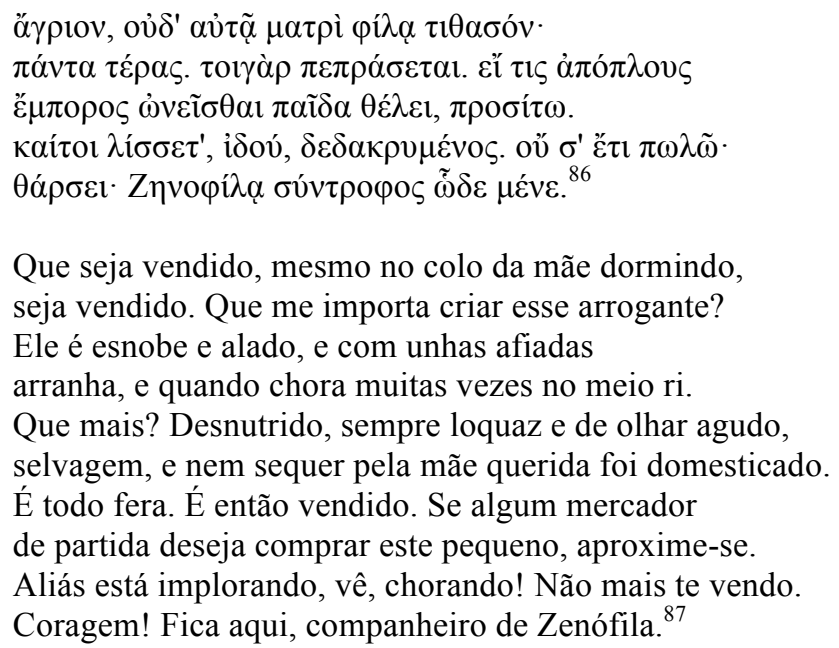

Nesse epigrama, Eros é um deus essencialmente ardiloso, cuja tranquilidade dissimulada atrai o amante para a sua proximidade indefesa, para que ele possa, então, mostrar as armas que esconde. Essa duplicidade de caráter nos faz lembrar a estátua do Eros de Rodes, cuja doçura ofusca toda a ferocidade das setas guardadas em sua aljava.

Como divindade primordial, Eros tem forte presença na filosofia e na poesia gregas arcaicas, porém seu culto parece não ter atingido grandes proporções na Grécia, embora pudesse ocorrer em locais isolados, mencionados por Pausânias, como Megara, Corinto, Epidauro, Atenas, Samos, Leuctra e Abidos. Segundo o autor, as principais celebrações dedicadas a ele ocorriam em Párion, no Helesponto, e em Téspias, na Beócia, aos pés do Monte Hélicon, local sagrado também para as Musas, que abrigava célebres estátuas dos Eros de Praxíteles e de Lisipo ${ }^{88}$. Pausanias diz que nesse local ocorria um festival chamado Erotidia ${ }^{89}$, que era celebrado a cada quatro anos pelos téspios, em que ocorriam competições e performances musicais. Estima-se que esses eventos passaram a ocorrer por volta do século II a.C. e continuaram a ser celebrados até o século III d.C., atraindo visitantes ao local. No mundo romano, no entanto, não há evidências consistentes de cultos dedicados exclusivamente a Cupido, mas sua presença na religião é fortemente associada a Vênus, como veremos mais adiante.

Pausânias ${ }^{90}$ menciona um Eros arqueiro de Lisipo em bronze, feito para os habitantes de Téspias. Este exemplar em mármore, abaixo, parece, antes de tudo,

\footnotetext{
${ }^{86}$ Meleagro, A. P. 5.178.

${ }^{87}$ Tradução de F. V. Amaral.

${ }^{88}$ Paus., 9.27.1.

${ }^{89}$ Paus., 9.31 .3

${ }^{90}$ Paus., 9.27 .1
} 
reproduzir o lugar e o movimento de um tipo de releitura helenística que está a serviço de sua desenvoltura com o arco, registrando o momento anterior à flechada:

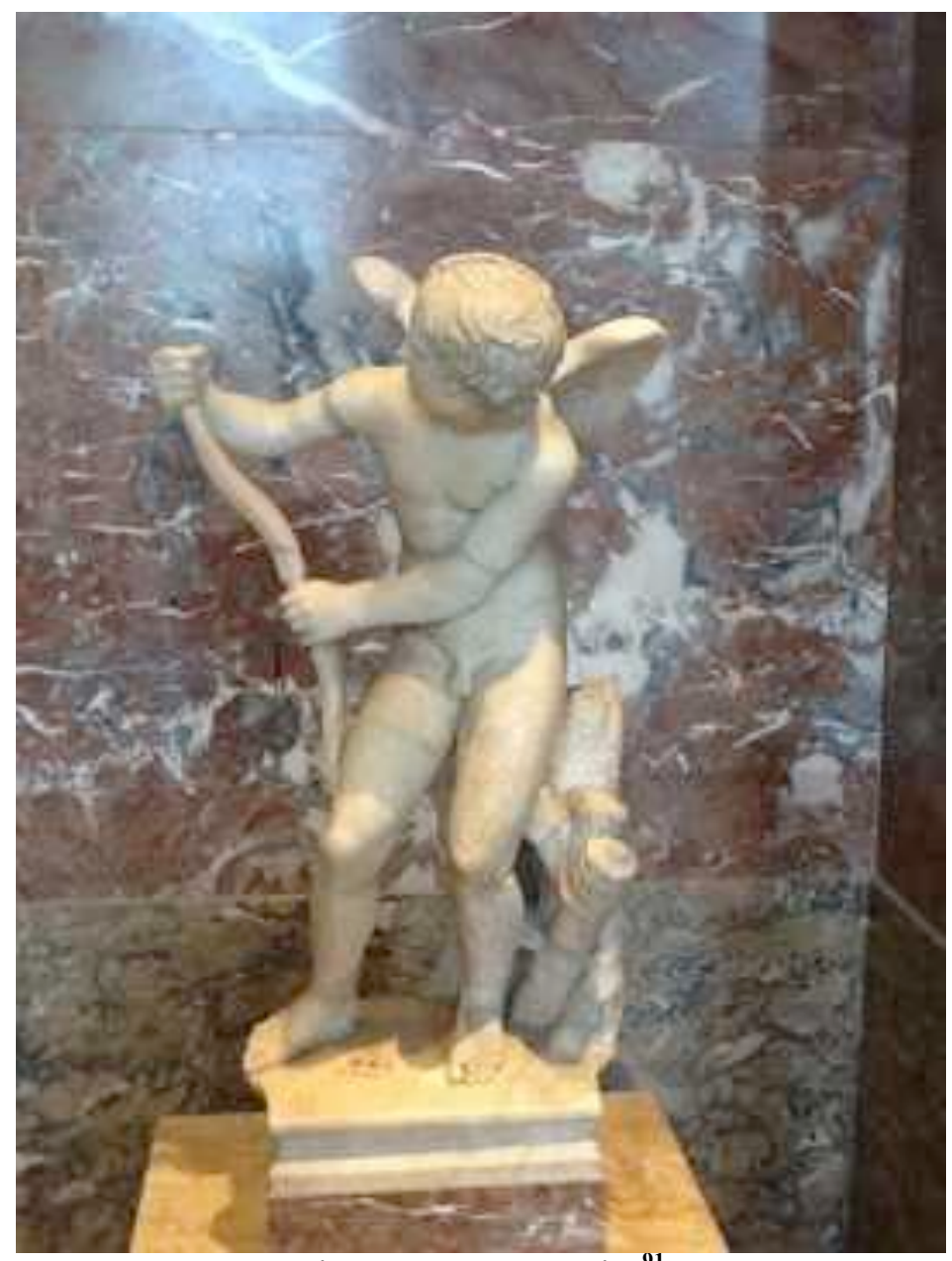

Figure 7. Eros arqueiro ${ }^{91}$

O Eros da pintura abaixo, da Casa de Marco Lucrécio Fronto, localiza-se ao centro de um conjunto de figuras que compõem o tema do amor de Ares e Afrodite. Ares, com o elmo na cabeça e vestindo uma túnica, toca o seio de Afrodite, que tem os cabelos adornados com um diadema, e cuja veste cobre todo o corpo. Cupido, ao centro, segura o arco e tem o quadril levemente inclinado, posição que sugere movimento; esta atitude corporal e atributos remetem ao modelo do Eros arqueiro que se reproduziu em larga escala em estátuas, como a que mencionamos acima. Nesta pintura, além dessas figuras,

\footnotetext{
${ }^{91}$ Louvre. Eros with bow. Inventaire MR 145 ( $\mathrm{n}^{\circ}$ usuel Ma 443). Roman period (2nd century AD?). Parian marble? H. $67 \mathrm{~cm}$. The little god of love is presented here as a winged infant holding a bow, with a quiver at his feet. This type of archer Eros is known to us from some forty-odd antique copies measuring 1.23 metres in height, and a few smaller copies like the one presented here. The Louvre figure is based on the Eros created between 338 and 335 BC by the Greek sculptor Lysippus for the temple at Thespies (Boeotia, central Greece). The lost bronze original is mentioned by Pausanias (Guide to Greece, 9.27.3). The wings, the forearms and the bow, part of the support at the back and the base with the cladding are modern restorations. Former Borghese collection. Purchased in 1807. Department of Greek, Etruscan, and Roman Antiquities.
} 
há cinco outros personagens que completam a cena, que já foi interpretada de diversas maneiras; uma das mais comuns sugere que este seja o momento em que Ares e Afrodite são flagrados em adultério; outra interpretação diz que esta é a cena do casamento entre Marte e Vênus, sendo Hímen a figura com asas na testa:

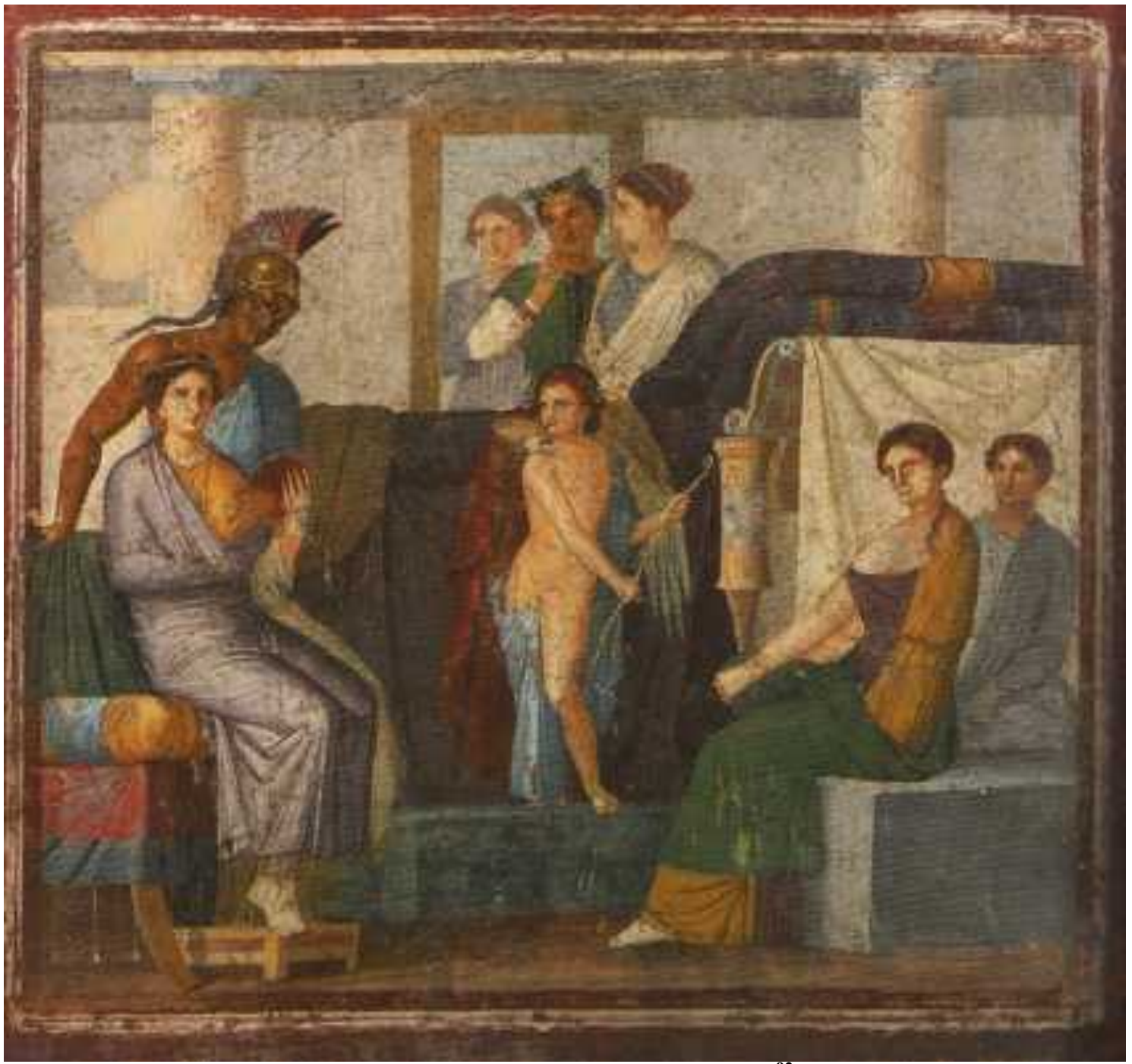

Figura 8. Casamento de Marte e Vênus ${ }^{92}$

Nessa pintura, Eros, como figura central, iconiza a relação amorosa entre esses dois deuses, seja ela adúltera ${ }^{93}$ ou familiar ${ }^{94}$, sobre a qual discutiremos em maiores detalhes no capítulo 7, Militia Amoris. Segundo Touratsoglou ${ }^{95}$, na arte grega, desde o século IV a.C., cenas de casamento e de amores míticos eram o cenário preferencial de Eros.

\footnotetext{
${ }^{92}$ Parede norte do tablinum da Casa de Marco Lucrécio Fronto, Pompeia.

${ }^{93}$ Cf. Ov., Met. 4.170-ss. Cic., N. D. 3.59.

${ }^{94}$ Ov., Am. 2.9.b

95 Touratsoglou (2009:4) "Eros, the Greek". In: N. C. Stampolidis, Y. Tassoulas (ed.) Eros. From Hesiod's Theogony to Late Antiquity. Athens: Museum of Cycladic Art.
} 
O Eros do tipo Centocelle é considerado como uma concepção que se aproximaria do Eros de Téspias de Praxíteles, citado em textos de Plínio, o Velho, e de Pausânias:

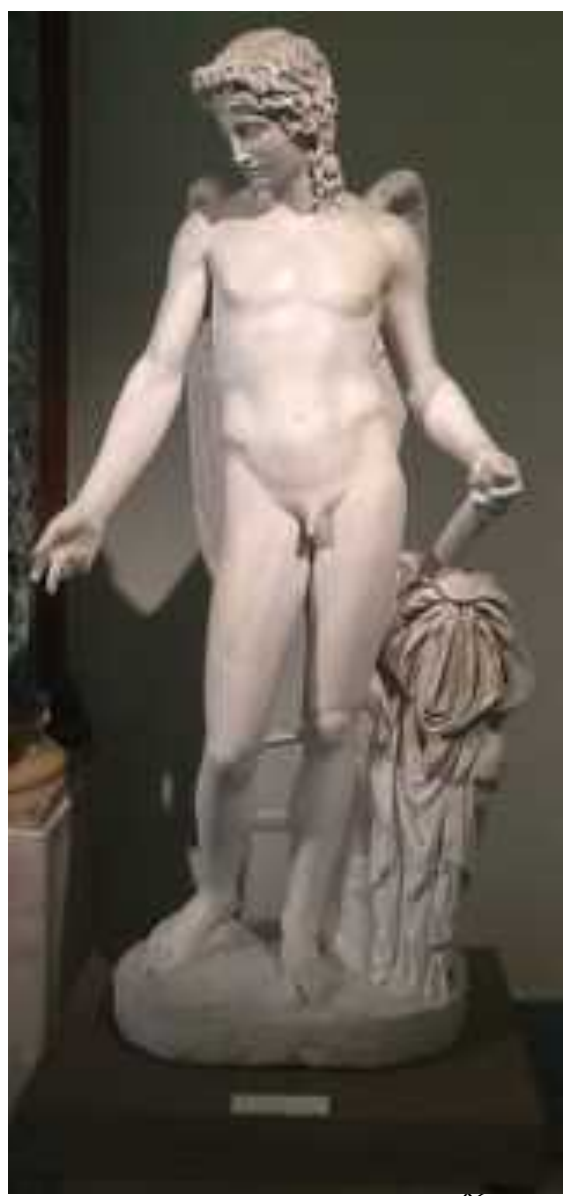

Figura 9. Eros Centocelle

Essa estátua, segundo Capaldi ${ }^{97}$, é uma das melhores deste tipo, evocando particularmente a expressão melancólica das divindades de Praxíteles. Pausânias relata

\footnotetext{
${ }^{96}$ Museo Archeologico Nazionale di Napoli. Statua di Eros tipo Centocelle. Inv. 6353. Copia di siconda metà II sec. d.C, da originale greco di IV séc. attribuito a Prassitele. Materia: marmo bianco a grana fine. Misure: Alt. M 1,65. Capaldi (2009:87): La figura di aspetto giovanile si mostra completamente nuda dopo haver deposto la clamide su un tronco che le fa da sostegno aderendo alla gamba sinistra; sulle spale reca due grosse ali. La testa è morbidamente incorniciata da una folda chioma ondulata, suddivisa nel mezzo da una scriminatura e trattenuta sulla fronte da una fiocco; di qui pendono sulla fronte due bande simmetriche di chiocche spiraliformi; lunghi riccioli a tortiglione ricadono sul collo. Il volto presenta un ovale delicato e quasi femineo dominato dall'ampia arcata sopraciliare, sotto cui spiccano gli occhi di taglio allungato com palpebre superiori espesse e taglienti e palpebre inferior dai margini stondati; la boca è appena dischiusa con le labbra morbide e carnose; il mento sfuggente. La statua Farnese è una replica dell'Eros di Centocelle, tipo statuario noto da un discreto numero di repliche al naturale e in formato riddoto. Ponderazione, trattamento de la capigliatura e resa dell'incarnato consentono di ricondurre al IV secolo a.C. la genesi del protótipo, con una spiccata propensione per il suo inserimento nella produzione prassitelica. Il ritmo chiastico dela figura ha indotto parte dela critica ad advanzare un'attribuizione a scuola policletea. [...] Alcune repliche conferiscono alla figura tratti infantil; la replica di Napoli, como quelle dell'Ermitage, Torino e Tours la raprpresentano di aspetto efebico. Le ali connotano il personaggio come Eros.

${ }^{97}$ Capaldi (2009:87).
} 
uma anedota sobre o Eros de Téspias, em que a estátua de mármore é doada pelo escultor a Frine, que o induziu a revelar qual de suas obras ele considerava a mais bela para que, então, escolhesse para si. Guerreri ${ }^{98}$ observa que a imagem de Eros, no Simpósio de Platão ${ }^{99}$, nas palavras de Agatão, como o mais belo, delicado, jovem e melhor dos deuses, remete à do eromenos com sua perfeita beleza, que, por sua vez, pode ser comparada com a do Eros de Praxíteles.

Plínio, o Velho, menciona duas estátuas de Éros esculpidas por Praxíteles ${ }^{100}$, uma feita para os habitantes de Téspias e outra para os habitantes de Párion, relatando que a primeira foi levada para Roma como espólio de guerra por volta do governo de Calígula $^{101}$, devolvida a Téspias durante o governo de Cláudio, e novamente removida para Roma por Nero, que a colocou no Pórtico da Scholae Octaviae, onde foi destruída por um incêndio ${ }^{102}$. Esta passagem nos dá a dimensão da importância da estátua em Roma, onde era considerada entre as mais notáveis:

\begin{abstract}
Praxitelis aetatem ${ }^{103}$ inter statuarios diximus, qui marmoris gloria superavit etiam semet. opera eius sunt Athenis in Ceramico, sed ante omnia est non solum Praxitelis, verum in toto orbe terrarum Venus, quam ut viderent, multi navigaverunt Cnidum. [...] aedicula eius tota aperitur, ut conspici possit undique effigies deae, favente ipsa, ut creditur, facta. nec minor ex quacumque parte admiratio est. Ferunt amore captum quendam, cum delituisset noctu, simulacro cohaesisse, eiusque cupiditatis esse indicem maculam.

sunt in Cnido et alia signa marmorea inlustrium artificum, Liber pater Bryaxidis et alter Scopae et Minerva, nec maius aliud Veneris Praxiteliae specimen quam quod inter haec sola memoratur. eiusdem est et Cupido, obiectus a Cicerone Verri "ille, propter quem Thespiae visebantur," nunc in Octaviae scholis positus; eiusdem et alter nudus in Pario colonia Propontidis, par Veneri Cnidiae nobilitate et iniuria. adamavit enim Alcetas Rhodius atque in eo quoque simile amoris vestigium reliquit. ${ }^{104}$
\end{abstract}

Praxíteles, cuja época mencionamos entre os estatuários, superou até a si próprio com a glória de seus mármores. Há obras suas no Cerâmico, em Atenas; porém, superior a todas, não só de Praxíteles, mas de todo o orbe da Terra, é a Vênus, que muitos navegavam até Cnido para ver. [...] Seu nicho, totalmente aberto, permite que a estátua seja vista de todos os lados, e acredita-se que tenha sido feito desse modo com o favor da deusa. E todas as partes são igualmente dignas de admiração. Dizem que um homem uma vez se apaixonou por ela e, escondido à noite, abraçou a estátua, e que uma mancha é indício de tal paixão.

Há, em Cnido, outras estátuas de mármore de ilustres artífices: um Líber Pater de Briaxe, e, de Escopas, outro Líber e uma Minerva; mas não há um exemplar que supere a Vênus de Praxíteles, que, entre estas, é a única a ser lembrada.

É dele também o Cupido que foi o motivo da censura de Cícero a Verres, "aquele, por causa do qual Téspia era visitada", agora exposto na Schola de Otávia; e, dele,

\footnotetext{
${ }^{98}$ Guerreri (2007:54).

${ }^{99}$ Platão, Sym. 194e-196c.

${ }^{100}$ Eros de Praxíteles, cf. Paus., 9.27.1.

${ }^{101}$ Paus., 9.27.3.

${ }^{102}$ Também mencionado em Paus., 9.27.3.

${ }^{103}$ Cf. P1., Nat. 34.69-70.

${ }^{104}$ Plin., Nat. 36.20-22.
} 
ainda há um outro, nu, em Pário, a colônia no Mar de Mármara, equiparado à Vênus de Cnido em nobreza e na injúria sofrida. Pois Alcetas de Rodes apaixonou-se por ele, e nele deixou semelhante vestígio de seu amor.

\title{
O Eros de Praxíteles é mencionado em epigramas de Meleagro, como este,
} abaixo, que dá ênfase à beleza da estátua de mármore e ao parentesco do deus com Vênus:

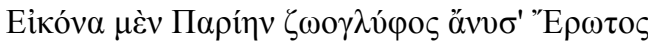

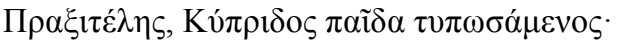

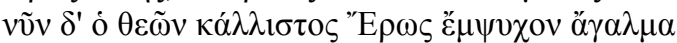

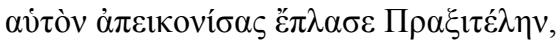

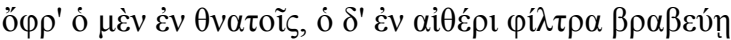

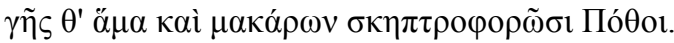

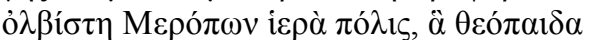

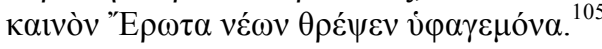 \\ Em mármore pário Praxíteles, o escultor, fez uma imagem de Eros, \\ modelando o filho de Cípris. \\ Agora Eros, o mais belo dentre os deuses, representando-se \\ esculpiu Praxíteles, estátua vivente \\ para que um entre os mortais e o outro no céu, controle os encantos, \\ e que os ditosos Desejos rejam sobre a terra e os mortais. \\ Fortunada a sagrada cidade dos Méropes, que nutriu \\ um filho divino, novo Eros, condutor de jovens. ${ }^{106}$
}

Neste outro epigrama, o poeta menciona a imagem do Eros de Praxíteles em metáforas de estátuas inertes e viventes: a estátua de Eros de Praxíteles, sem vida, feita de mármore frio, é análoga àquela que o poeta diz ter sido moldada e estar vivendo em seu interior:

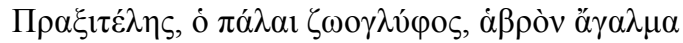

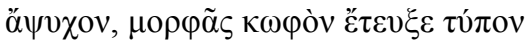

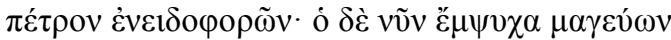

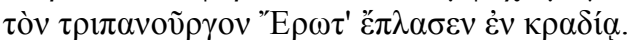

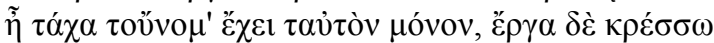
oủ $\lambda i ́ \theta o v, \dot{\alpha} \lambda \lambda \dot{\alpha} \varphi \rho \varepsilon v \tilde{\omega} v \pi v \varepsilon \tilde{v} \mu \alpha \mu \varepsilon \tau \alpha \rho \rho v \theta \mu i ́ \sigma \alpha \varsigma$.

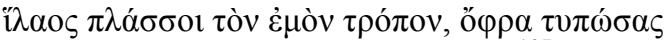

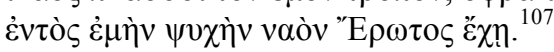

Praxíteles, antigo escultor, moldou uma imagem delicada, muda e sem vida ao dar forma à uma pedra.

O Praxíteles de agora, mágico da vida, modelou Eros, três vezes terrível, no meu coração. Talvez ele possua o mesmo nome, mas tem feitos soberbos, pois transformou não uma pedra, mas um ser pensante. Propício, ele poderia modelar o meu interior para que depois disso a minha alma fosse como templo de Eros. ${ }^{108}$

\footnotetext{
${ }^{105}$ Meleagro, A.P. 12.56 .

106 Tradução de F. V. Amaral.

${ }^{107}$ Meleagro, A. P. 12.57.
} 
Em Roma também havia estátuas de Pothos, como esta abaixo, um jovem nu, sem asas, com o torso inclinado para a esquerda:

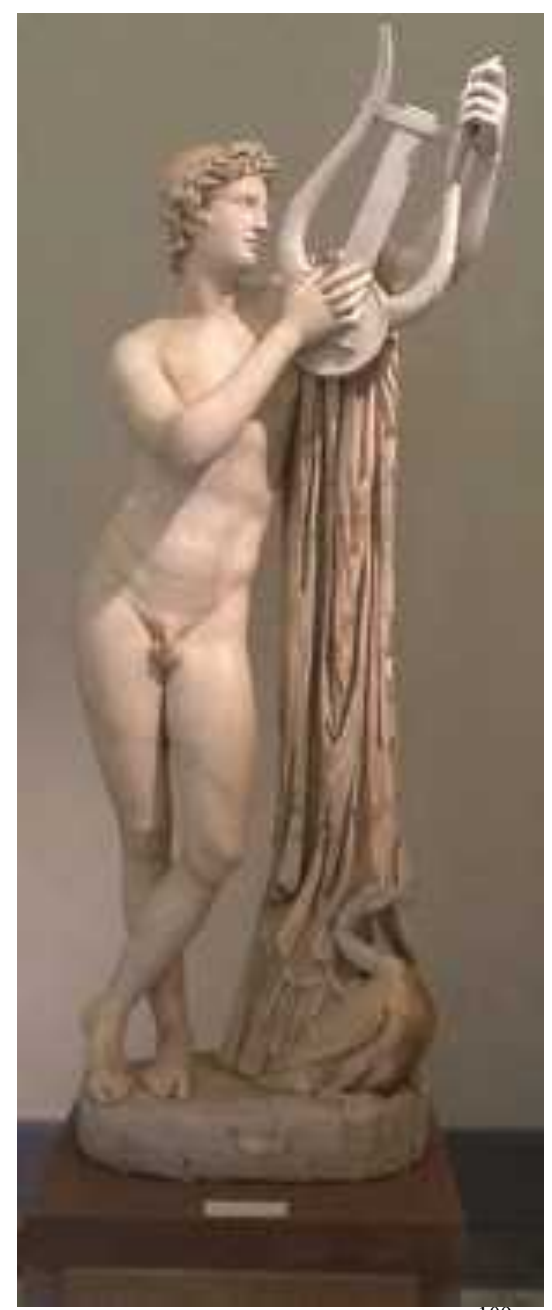

Figura 10. Estátua de Pothos

Numa anedota de Pausânias ${ }^{110}$, o Eros do santuário de Asclépio, em Epidauro, troca 'voluntariamente' o arco e flechas pela lira. A lira nas mãos desse Pothos em mármore, acima, por sua vez, segundo Capaldi ${ }^{111}$, foi adicionada por um restaurador. Esta estátua foi, por longo tempo, classificada como um Apolo, mas estudos concluíram que esta é provavelmente uma das variantes do que seria o exemplar de Pothos atribuído a Escopas, escultor célebre apontado por Plínio como autor de uma estátua que fazia par com uma Vênus na Samotrácia: is fecit Venerem et Pothon, qui Samothrace sanctissimis

\footnotetext{
108 Tradução de F. V. Amaral.

${ }^{109}$ Statua del Pothos. Museo Archeologico Nazionale di Napoli, Nápoles, Itália. Inv. 6253. Materia: marmo bianco cristalino a grana media (pario); testa in marmo pentelico. Misure: Altezza m. tot. 1,95; alt. della testa $\mathrm{m}$ 0,28. Proprio queste caratteristiche del volto e sopratutto l'abbondante uso del trapano corrente, suggeriscono anche per la testa, una datazione alla metà del II secolo d.C..

${ }^{110}$ Paus., 2.27.3.

${ }^{111}$ Capaldi (2009:92-95).
} 
caerimoniis coluntur $^{112}$ (Ele [Escopas] fez uma Vênus e um Pothos, que são adorados nos mais solenes rituais da Samotrácia). Pausânias ${ }^{113}$, que também menciona obras de Escopas, por sua vez, atribui também ao escultor, um Pothos, um Himeros e um Eros que teriam pertencido ao templo de Afrodite em Megara. Ele sugere que cada nome evidencie uma função diferente:

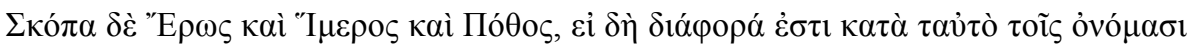

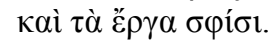

De Escopas são Eros, Himeros e Pothos, e, sem dúvida, suas funções são diversas como seus nomes.

\section{A pintura do Amor menino}

O tema da elegia 2.12 é uma pintura do Amor menino. Na primeira parte do poema, Propércio nos guia através do olhar do pintor sobre o objeto; e, na segunda, muda a perspectiva para o seu ponto de vista:

Quicumque ille fuit, puerum qui pinxit Amorem, nonne putas miras hunc habuisse manus? is primum vidit sine sensu vivere amantes, et levibus curis magna perire bona. idem non frustra ventosas addidit alas, fecit et humano corde volare deum: scilicet alterna quoniam iactamur in unda, nostraque non ullis permanet aura locis. et merito hamatis manus est armata sagittis, et pharetra ex umero Cnosia utroque iacet: ante ferit quoniam tuti quam cernimus hostem, nec quisquam ex illo vulnere sanus abit. in me tela manent, manet et puerilis imago: sed certe pennas perdidit ille suas; evolat heu nostro quoniam de pectore nusquam, assiduusque meo sanguine bella gerit. quid tibi iucundumst siccis habitare medullis? si pudor est, alio traice tela, puer! intactos isto satius temptare veneno: non ego, sed tenuis vapulat umbra mea. quam si perdideris, quis erit qui talia cantet, (haec mea Musa levis gloria magna tuast), qui caput et digitos et lumina nigra puellae et canat ut soleant molliter ire pedes? ${ }^{114}$

Quem quer que tenha sido aquele que pintou o Amor menino, não julgas que ele possuísse mãos admiráveis? Ele primeiro viu amantes viverem sem juízo, e grandes bens se perderem por amores vãos. O mesmo, com razão, adicionou asas ligeiras e fez o deus voar dentro do coração humano.

\footnotetext{
${ }^{112}$ Pl., Nat. 36.25.

113 Paus., 1.43.6.

${ }^{114}$ Prop., 2.12.
} 
É evidente, pois somos lançados no fluxo oscilante das ondas, e brisa favorável não permanece em lugar algum.

E merecidamente sua mão é armada com setas aduncas,

e uma aljava de Gnosso pende de seus ombros.

Porque fere antes que, seguros, possamos distinguir o inimigo, e ninguém escapa ileso dessa ferida.

Em mim as setas permanecem, e permanece a imagem pueril: mas certamente ele perdeu suas asas;

ah, pois não sai voando de meu peito para lugar algum, e, em meu sangue, assiduamente, promove guerras.

Porque te agrada habitar em um peito ressequido?

Se há pudor, atira as setas para outro lugar, menino!

É melhor atacar os intocados com este veneno:

não eu, mas minha tênue sombra está sendo açoitada.

Se a destruíres, quem é que há de cantar tais temas

(esta minha Musa leve é tua grande glória),

e que há de celebrar a face e os dedos e os olhos negros da menina,

e como seus pés costumam mover-se suavemente?

Fedeli ${ }^{115}$ considera perfeita a estrutura dessa elegia, que pode ser divida em duas partes: a primeira (1-12) dá ênfase às características de Amor, e a segunda (13-24) aos efeitos de suas ações; cada qual com três subdivisões de quatro versos com temas específicos: Amor menino (1-4), Amor alado (5-8), Amor armado (9-12); lamento do poeta porque o deus se alojou em seu coração (13-16), súplica para que ele encontre outro alvo (17-20), e exaltação da poesia erótica (21-24).

A questão da imagem permanece central ao longo de todo o poema: Propércio, inicialmente, nos faz ver, através dos olhos do pintor, os aspectos mais aparentes ou externos que compõem a imagem do deus; e, na segunda parte, propõe-se a falar sobre os efeitos e transformações causados pela ação do deus: Amor, alojado no peito, empresta algumas de suas características ao poeta, que assimila a imagem pueril; e também transforma os amantes, que agem como crianças, sem juízo e deixando perecer os bens mais preciosos.

Segundo Paulo Martins ${ }^{116}$, a elegia 2.12 de Propércio pode ser observada como:

a pintura da pintura, pois trata de uma pintura com palavras. Ao falar que o pintor tinha mãos admiráveis por ter pintado o Amor criança, elabora a euidentia do objeto, destacando os atributos típicos de Cupido, tanto sob o ponto de vista anímico, como corpóreo, atribuindo-lhe, também, matiz ético, pois põe em relevo suas ações.

Mirus, adjetivo no acusativo feminino plural miras, atribuído às mãos do pintor que produziu a obra, é uma palavra que pertence ao repertório do discurso epidítico, indicando o maravilhoso, a admiração e a reverência diante de algo que se vê. $O$ discurso encomiástico dedicado a descrições de obras de arte foi amplamente utilizado

\footnotetext{
${ }^{115}$ Fedeli (2005:340).

${ }^{116}$ Martins (2011:123).
} 
por autores a partir do século II d.C., como Calístaro, Filóstrato, o Jovem; e Filóstrato, o Velho, que elaboraram textos exclusivamente dedicados a pinturas e esculturas existentes ou fictícias. Em Eikones 1.6, Filóstrato descreve uma pintura na qual um grupo de Erotes com aljavas e setas de ouro brinca entre as macieiras de um pomar. Esse procedimento encontra-se sistematizado nos Progymnasmata, manuais de introdução à retórica para meninos em idade escolar, recebendo o nome de écfrase, que, além desta, possui outras vertentes. O repertório apresentado nesses textos, elaborados entre os séculos II e IV d.C. por autores como Hermógenes e Aftônio ${ }^{117}$, segundo Cairns $^{118}$, consistia em um aparato mínimo para quem quisesse aprofundar-se nos campos da retórica. Embora a écfrase, como procedimento sistematizado, seja posterior ao poema de Propércio, a semelhança com o poema é notória.

Quintiliano, nas Instituições Oratórias, menciona o exercício que ele chama de chria, praticado por alunos de retórica, que consistia em responder questões que justificassem, por exemplo, atributos de deuses como Vênus e Cupido:

\begin{abstract}
Solebant praeceptores mei neque inutili et nobis etiam iucundo genere exercitationis praeparare nos coniecturalibus causis cum quaerere atque exequi iuberent 'cur armata apud Lacedaemonios Venus' et 'quid ita crederetur Cupido puer atque uolucer et sagittis ac face armatus' et similia, in quibus scrutabamur uoluntatem, cuius in controuersiis frequens quaestio est: quod genus chriae uideri potest. ${ }^{119}$

Os meus preceptores estavam acostumados, não inutilmente e até mesmo de maneira agradável, a me preparar a partir de causas conjeturais em um tipo de exercícios quando ordenavam que eu discutisse e desenvolvesse: 'Por que Vênus junto aos lacedemônios (em Esparta) estava vestida com armadura' e ainda 'por que se acreditava que Cupido era um menino alado e armado de setas e tocha' e outras questões semelhantes. Nesses exercícios eu procurava com cuidado a intenção dele, uma vez que nas controvérsias a questão é freqüente: isto pode parecer uma espécie de chria. ${ }^{120}$
\end{abstract}

Como observa-se na passagem acima, o exercício poderia partir de uma conjectura, como a que sugere Quintiliano - "quid ita crederetur Cupido puer atque uolucer et sagittis ac face armatus?" -, e, então, o aluno deveria discutir e desenvolver tais lugares-comuns. Estima-se que exercícios como esse mencionado por Quintiliano já fizessem parte do repertório romano desde o século III a.C. ${ }^{121}$, isto é, antes mesmo de

\footnotetext{
${ }^{117}$ Rodolpho (2010:108).

${ }^{118}$ Cairns (2010:75).

${ }^{119}$ Quint., Inst. Or. 2.4.26.

${ }^{120}$ Tradução de P. Martins. Chria: desenvolvimento oratório de lugar-comum.

${ }^{121}$ Cairns (2010:75).
} 
Quintiliano escrever as Instituições Oratórias ${ }^{122}$. Assim, deduz-se que Propércio, que viveu por volta de 55 a 16 a.C., em sua formação, tenha exercitado essas práticas retóricas que eram correntes entre os romanos de sua época, embora isso não signifique que ele esteja necessariamente aplicando qualquer dos procedimentos acima mencionados. De todo modo, o poema de Propércio explicita alguns aspectos propostos para discussão no exercício citado por Quintiliano, justificando a idade, as armas e asas de Cupido.

\section{Os signa amoris}

Como havíamos dito, os romanos consideram o amor como uma doença, um mal incontrolável, que desencadeia sintomas de ordem física e mental, os signa amoris, entre eles, principalmente, aceleração da respiração, vertigens, tremores, palpitações e perda da razão. Há toda uma fisiologia ${ }^{123}$ referente à manifestação da "doença" que se evidencia na elegia 2.12: Amor se aloja na região peitoral, como indica o ablativo humano corde, e o veneno das flechadas atinge a medula e circula no sangue, impulsionando o poeta para os combates da militia amoris. Segundo Syndicus ${ }^{124}$, relacionar as contradições e dores do amor às características de Eros era algo comum em epigramas helenísticos. Esse autor aponta alguns epigramas de Meleagro podem ter sido possíveis fontes da elegia 2.12, tais como: o 5.190 da Antologia Palatina, em que evidencia-se quanto esse deus pode ser perigoso, com a comparação entre o tormento dos amantes e as tempestades marítimas; e no 5.180, em que enfatiza-se o poder das setas, entre outros.

\section{As asas}

Um elemento essencial da caracterização física de Amor são as asas (alae, pennae), que proporcionam o ângulo e a velocidade necessárias para que seus ataques seja ainda mais ameaçadores; a elas é atribuído o adjetivo ventosae $e^{125}$, uma qualidade que remete aos atributos do vento. Há, nessa metáfora, uma transferência de sentido relacionada ao movimento, à leveza e à velocidade ao voar. O rápido bater das asas

\footnotetext{
122 Século I d.C..

${ }^{123}$ Calame (1999:19).

${ }^{124}$ Syndicus (2006:269-70). In: Gunther (ed.) Brill's Companion to Propertius. Leiden: Brill.

125 Prop. 2.12.5.
} 
agita o ar numa espécie de turbilhão que, ao atingir o alvo, imediatamente afeta o equilíbrio físico e mental, provocando os sintomas acima mencionados. Por outro lado, a ligeireza das asas pode ser também uma metáfora para a elocução elegíaca, no quesito da concisão calimaquiana, remetendo à ideia de texto rápido, ágil, ligeiro e diminuto: as asas ligeiras do verso.

O tópos de Eros com os atributos do vento se encontra na lírica arcaica, como nestes versos de Safo:

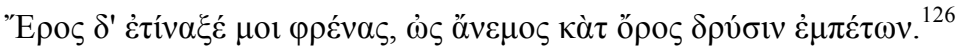

Eros sacudiu meus sensos, qual vento montanha abaixo caindo sobre as árvores" ${ }^{127}$.

Meleagro também atribui a Eros poder sobre o vento, que provoca 'tempestades' que afetam o juízo e levam os apaixonados à insânia:

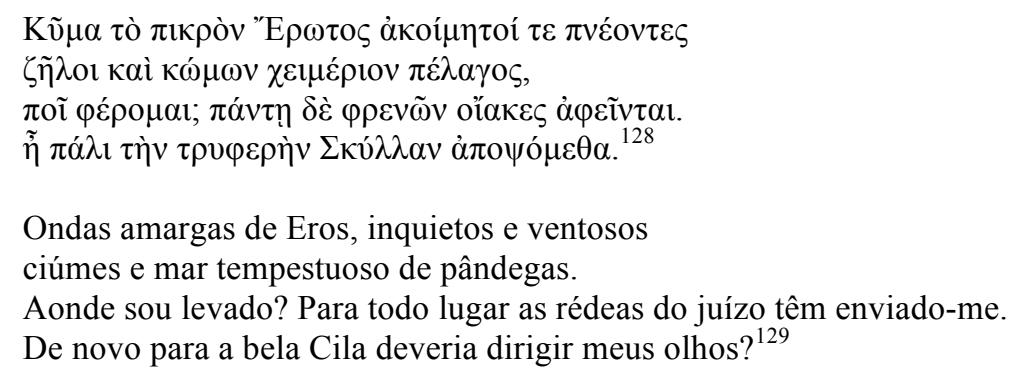

Assim também Propércio na elegia 2.12, que, sob os auspícios do deus, fica à mercê do vento e do fluxo das ondas.

\section{As armas}

Propércio dá ênfase ao caráter belicoso de Amor, caracterizando-o como um inimigo (hostis) ${ }^{130}$ rápido, imbatível e inescapável, cujas setas agressivamente o transpassam até os ossos, causando terríveis dores e uma ferida que nunca cicatriza. A violência e o porte de armas são atributos fundamentais de Cupido na poesia latina de

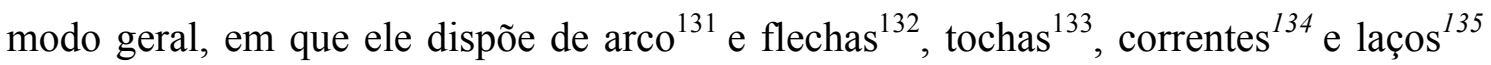

\footnotetext{
${ }^{126}$ Safo, frag. 47 Voigt.

127 Tradução de G. Ragusa (2005:288).

${ }^{128}$ Meleagro, A.P. 5.190.

${ }^{129}$ Tradução de F. V. Amaral.

${ }^{130}$ Cf. também Ov., Am. 2.9.a; e Prop. 4.1.135-8, em que o poeta diz que os Cupidos do exército de Vênus serão inimigos úteis no seu aprendizado da elegia. Sobre essa tópica: Fedeli (2005:350-1).

${ }^{131}$ Arcus: Ov., Am. 1.1.23; 1.9.11; 1.11.11; 1.15.27; 2.9.a.5; 2.7.27; 3.9.8; 2.8, 27; 3.2.55; Prop. 1.9.21; 1.8.15; Tib., 2.5.103; 2.1.69.
} 
para exercer sua impiedosa dominação. Ovídio, por exemplo, inicia os Amores construindo uma imago de Cupido em que evidencia o uso reiterado do arco e flechas $^{136}$. O campo semântico das armas é uma das principais fontes de metáforas sexuais na Língua Latina, como explica Adams ${ }^{137}$ em seu livro The Latin Sexual Vocabulary:

This is the largest category of metaphors of our general type [pointed objects]. No single word for a weapon seems to have become a banal term for the penis in Latin, but the frequency of ad hoc metaphors both in Greek and Latin shows that the sexual symbolism of weapons was instantly recognizable in ancient society. Words for weapons lent themselves readly for risqué jokes.

O formato das setas - pontiagudas, contundentes e penetrantes - alude ao órgão sexual masculino. Segundo Adams, o arco também é metáfora sexual: além da sua forma, a capacidade da corda de tensionar e relaxar carrega esse duplo sentido.

Em Amores 2.9b, o verbo figere ${ }^{138}$ marca uma das principais ações de Cupido que é ferir, furar ou atravessar com sua seta, ação que desencadeia um páthos exacerbado:

sic me saepe refert incerta Cupidinis aura, notaque purpureus tela resumit Amor.

Fige, puer! positis nudus tibi praebeor armis; hic tibi sunt vires, hac tua dextra facit; huc tamquam iussae veniunt iam sponte sagittae vix illis prae me nota pharetra sua est ${ }^{139}$

A instável brisa de Cupido amiúde me reconduz, e o reluzente Amor retoma as armas que eu bem conheço.

Transpassa-me, menino! Com as armas depostas, apresento-me nu diante de ti; aqui reside tua força, aqui tua destra ataca; tuas setas chegam como se fossem requisitadas, elas mal notam sua aljava por minha causa.

\footnotetext{
${ }^{132}$ Sagitta: Tib., 2.1.18; 2.5.105, 2.6.15; Prop. 2.12.9; 2.29.5; Ov., Am. 1.1.25; 1.2.7 e 45; 2.9.37; spicula: Ov., Am. 1.1.22; Prop. 2.13.2; ou telum: Prop., 2.9a.38; Tib., 2.5.107; 2.6.4-15; 2.12.13-18; Ov. Am. 2.9.13.34.

${ }^{133}$ Fax: Tib. 2.1.82, Prop. 2.24.5; 3.16.16; 4.3.50; 4.4.70; Ov., Am. 1.1.8; 2.9. 5; 3.9.8. Flamma: Ov., Am., 1.2.46; 2.1.8. Pichon (1991:144): Fax: sed multo saepius faces sunt arma Amoris, quibus hominum pectoribus ignem cupiditatis.

${ }^{134}$ Catena: Ov., Am. 3.11, 3; Tib. 2.4.3; Prop. 2.15.25. Pichon (1991:102): Catena: modo in deteriorem partem accipitur, et durum amantium seruitium significat.

${ }^{135}$ Vinculum: Tib. 2.4.4.; Ov., Am. 1.2.30; Prop. 2.15.25.

${ }^{136}$ Ov., Am. 1.1: Seta: pharetra (21) ou sagitta (25), spicula (22) Ferrão ou ponta de flecha, ou "flecha" por metonímia. Arco: sinuosum arcum (23) e neruus (v.18), que alude ao arco.

${ }^{137}$ Adams (2002:19)

${ }^{138}$ Pichon (1991:148): figere: plerumque allegorice de spicullis accipitur quibus Amor hominum pectora uerberat. Outras ocorrências: Tib., 2.1.71, Prop., 2.9.39; 2.8.2.

${ }^{139}$ Ov., Am. 2.9b.33-38.
} 
A imagem do poeta atormentado pelas flechadas remete a um epigrama de Meleagro, que diz que Eros cravou-lhe todas as suas setas aladas:

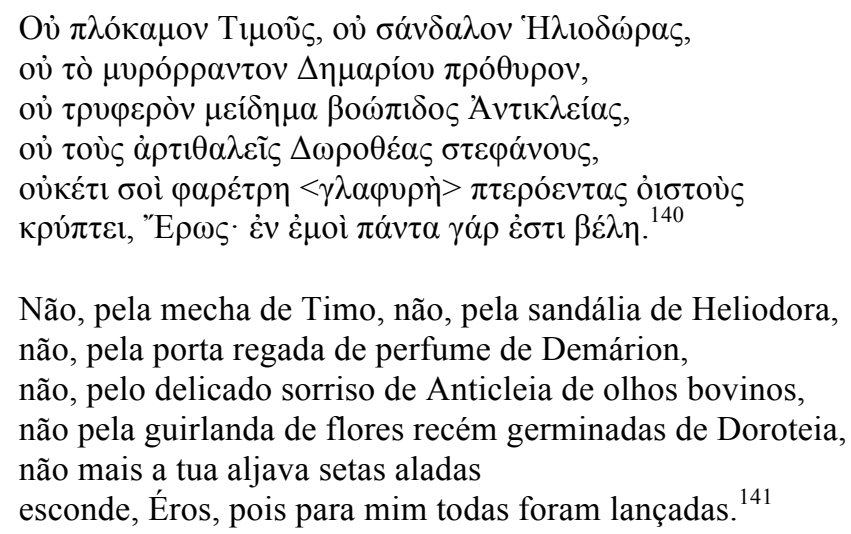

A diferença entre este epigrama e a elegia acima mencionada está na reação do poeta ao ataque: Ovídio não quer evitar o ataque e suplica para que Cupido o atinja no peito e para que reine ali com sua pulchra Matre ${ }^{142}$, submetendo-se à servidão voluntária $^{143}$, um comportamento determinante do êthos do amator em elegias augustanas.

O intaglio romano do século II d.C., abaixo, reproduz o lugar-comum que observamos nos versos acima, em que Cupido aponta seu arco e flecha contra um adversário nu e desarmado, evidenciando o desnível de forças no embate:

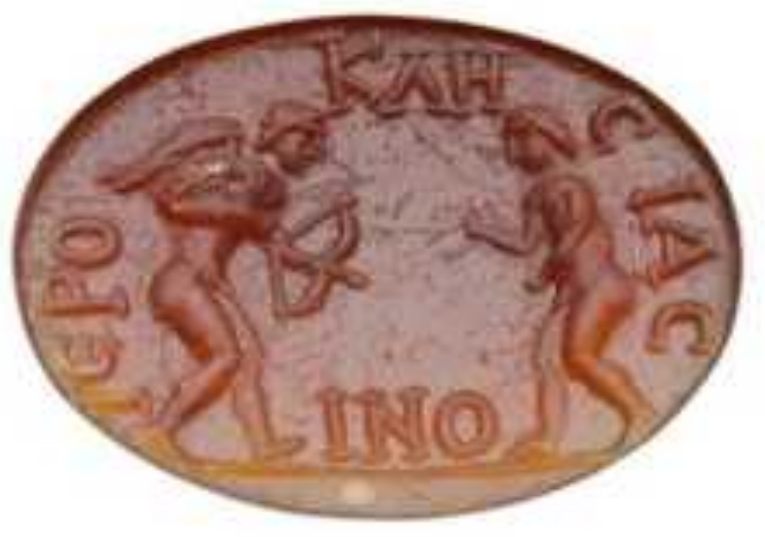

\footnotetext{
${ }^{140}$ Meleagro, A.P. 5.198.

${ }^{141}$ Tradução de F. V. Amaral.

${ }^{142}$ Ov., Am 2.9b 27-28.

${ }^{143}$ Propércio na elegia 2.9a.38-39, também implora para ser atingido: tela, precor, pueri, promite acuta magis, figite certantes atque hanc mihi solvite vitam!. Cf. Ov., Am. 1.2.19: "En ego confiteor! Sum tua noua praeda, Cupido."
} 
Figura 11. Eros enfrentando um jovem ${ }^{144}$

\title{
O doce-amaro Amor
}

Nesta passagem abaixo, Tibulo evidencia o caráter dual de Amor, que combina aparência tênue com conduta austera e hostil:

\begin{abstract}
Semper, ut inducar, blandos offers mihi voltus, Post tamen es misero tristis et asper, Amor. Quid tibi saevitiae mecum est? an gloria magna est Insidias homini conposuisse deum? ${ }^{145}$

Sempre me ofereces tua tênue face, para atrair-me, no entanto, depois, te tornas austero e hostil, infeliz Amor! O que queres de mim, cruel menino? Há grande glória para um deus que arma emboscadas para os homens?
\end{abstract}

Nesta outra elegia, Tibulo constrói uma imagem de Amor particularmente religiosa ${ }^{146}$ e encomiástica, com a ambiguidade inerente do tópos de Eros doce-amargo: o belicoso deus que tem o poder de ferir gravemente com suas setas e tochas, também pode ser pacífico ( placidus $^{147}$ ) e auspicioso, se aplacado:

A miseri; quos hic graviter deus urget, at ille

Felix, cui placidus leniter adflat ${ }^{148}$ Amor.

Sancte, veni dapibus festis, sed pone sagittas

Et procul ardentes hinc precor abde faces. ${ }^{149}$

Ah, infelizes daqueles a quem esse deus oprime com gravidade,

e feliz daquele a quem o pacífico Amor é propício.

Venerável, compareça em nossos sagrados festins, porém deixa de lado tuas flechas

E, suplico, afasta para longe de nós tuas ardentes tochas.

Ovídio também o caracteriza como um ser ambíguo, qualificando-o ora como tener $^{150}$, ora como ferus ${ }^{151}$ ou saeuus ${ }^{152}$. Em Am. 2.9.b, o poeta utiliza também outro

\footnotetext{
${ }^{144}$ Carved Intaglio with Eros fighting a youth. Roman, Imperial Period, 2nd century A.D.. Length x width: 14 x $11 \mathrm{~mm}$ (9/16 x 7/16 in.). Sard. Classification: Jewelry / Adornment. Eros with wings, bow and arrow, stands at right facing nude male without wings who presents himself in a boxing stance. Around the edge of the intaglios is a Greek Inscription: 'Hierokles, son of Jason". Museum of Fine Arts, Boston.

${ }^{145}$ Tib. 1.6.1-4.

${ }^{146}$ Pichon (1991:258): Sanctus: non raro a religioso sermone ad amatorium transfertur. Sic dicitur: sanctus Amor. Cf. Cat., Carm. 64.93; Prop. 2.24.41.

${ }_{147}$ Pichon (1991:234): Placidus: quoque Amor,cum non grauia minatur hominibus.

${ }^{148}$ Pichon (1991:79): Adflare: est quoque amantibus prodesse uenti modo.

${ }^{149}$ Tib., 2.1.80-4.

${ }^{150}$ Ov., Am. 2.18.4; 2.18.19; 3.1.69; 3.15.1

${ }^{151}$ Ov., Am. 3.1.20. Pichon (1991:147): Ferus saepe uocatur Amor, fera quae facit.

${ }^{152}$ Ov., Am. 1.6.34.
} 
modo de introduzir o tópos, transferindo as caraterísticas contrastantes de Amor para a amada, da qual o poeta não quer desvencilhar-se, por considerá-la um doce-mal:

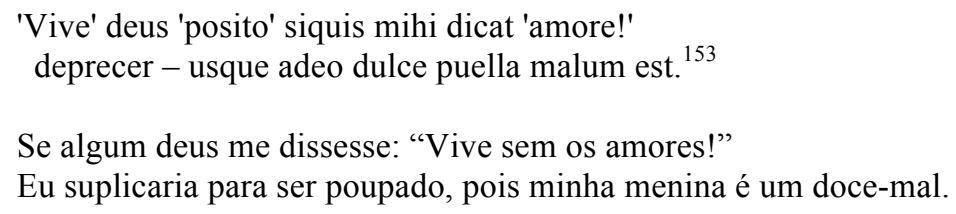

Desse modo, tudo o que envolve amor é essencialmente dual e conflitante, incluindo as personae dos envolvidos nos jogos de Cupido.

É de Safo a mais antiga menção ao tópos de Eros doce-amargo ( $\gamma \lambda v \kappa u ́ \pi ı \kappa o \varsigma)$ :

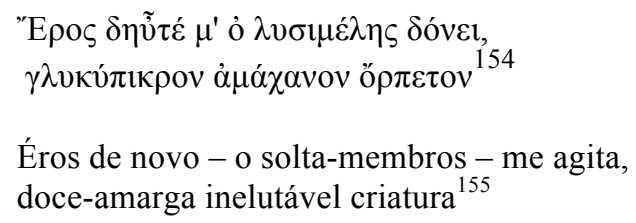

Anne Carson ${ }^{156}$ comenta sobre a percepção de Eros na perspectiva da persona poética no frag. 130 de Safo, ressaltando que o deus se desloca para o interior de sua vítima sem permitir defesa, e, portanto, não age como um aliado, mas força sua entrada de modo hostil. A amargura deve ter o gosto desta hostilidade, e traduz-se em ódio.

Como diz Giuliana Ragusa ${ }^{157}$, "gluku-pikros é uma mistura de sabores dada numa sequência provavelmente eloquente: ao doce segue-se o amargo". Nesse sentido, já comentamos que Eros utiliza seu poder de sedução para atrair humanos e deuses para a experiência erótica, proporcionando, em seguida, terríveis amarguras: a dor, as lágrimas e o sofrimento. Como diz Propércio: quod saepe Cupido huic malus esse solet, cui bonus ante fuit. ${ }^{158}$ (Cupido costuma causar males àqueles a quem antes beneficiou), ou seja, ele oferece primeiro o lado bom, para depois revelar a que veio, um mecanismo que garante que, mesmo com seu caráter extremamente violento, ele consiga acessar e subjugar a quem quer que seja, sem a princípio, ter que lançar mão de seu poder de fogo. Em suma, os elementos conflitantes de sua persona, reverberam na experiência erótica, que conjumina prazer e dor, brandura e violência, doçura e amargura.

\footnotetext{
${ }^{153}$ Ov., Am. 2.9b.25-26.

${ }^{154}$ Frag. 130 Voigt.

155 Tradução de G. Ragusa.

${ }^{156}$ Carson (2009:3).

${ }^{157}$ Ragusa (2009:355).

${ }^{158}$ Prop, 2.18a.21.
} 
Álcman, no frag. 58 Dav., mencionado anteriormente, caracteriza Eros como selvagem, um adjetivo que evidencia o caráter ameaçador dessa divindade, que tem o poder de desencadear a loucura, a inconsequência e a lascívia. Segundo Ragusa ${ }^{159}$, tal adjetivo, depois de Álcman, só "lhe será novamente conferido bem mais tarde, na poesia helenística", como se nota nesse epigrama de Meleagro, em que Eros é selvagem e doce-amargo:

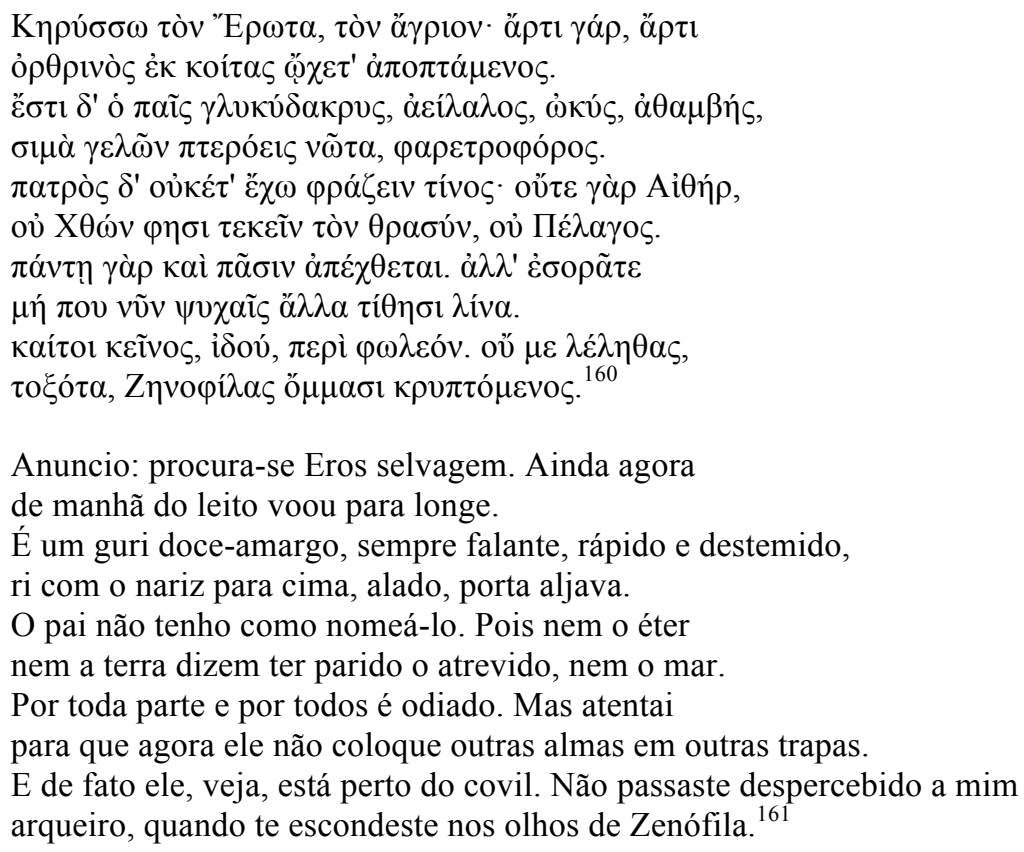

Em Odes 4.1, Horácio utiliza uma antonomásia em substituição ao nome de

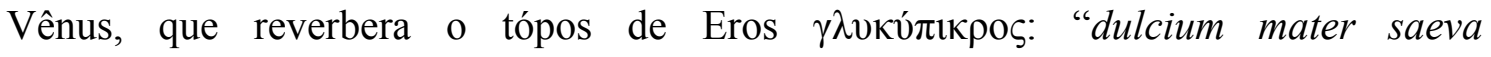
Cupidinum"162. A associação dessas qualidades contrastantes de mãe e filho nos dá a impressão de que Horácio os transforma em um todo orgânico, que os torna indissociáveis, como se estivéssemos falando de uma só criatura. Em Odes 1.19, Horácio aplica o tópos de maneira diversa, utilizando a mesma antonomásia, porém sem atribuir a doçura aos Cupidos, mas deslocando-a para a figura da resplandecente Glícera, cujo nome sugere essa característica. Nessa ode, a figuração de Vênus e dos Cupidos novamente se confunde, já que o adjetivo $\operatorname{saeuus(a)}$ recai sobre mãe ${ }^{163}$, embora saibamos que esta é uma das qualidades mais marcantes do filho na poesia latina ${ }^{164}$.

\footnotetext{
${ }^{159}$ Ragusa (2008:419-20).

${ }^{160}$ Meleagro, A. P. 5.177 .

161 Tradução de F. V. Amaral.

${ }^{162}$ Hor., Carm. 4.1.4-5.

${ }^{163}$ Comentam a aplicação do adjetivo saeuus a Vênus: Mayer (2012: 126).

${ }^{164}$ Saeuus Cupido, cf. Tib. 1.6.3; Ov., Am., 1.15; 1.6.34.
} 


\section{O riso cruel de Cupido}

Havíamos dito que nas Odes, Horácio constrói a imagem de Cupido associada à de Vênus, e com ênfase no seu caráter implacável, qualificando-o como feruidus ${ }^{165}$, ferus $^{166}$, lentus e importunus ${ }^{167}$, e, por vezes, atribuindo-lhe características mais suaves, como dulcis ${ }^{168}$. O tópos de Eros doce-amargo compreende o que Arkins ${ }^{169}$ chama de "cruel joke of Vênus", que é a situação tragicômica do amante incapaz de resistir aos apelos do amor. Em Odes 4.1, por exemplo, Horácio reluta em aceitar os desígnios da deusa, alegando que não estar mais condições de executar tais ordens, mas mesmo assim cai presa dos doces Cupidos, ainda que os efeitos se manifestem apenas em sonhos.

Cupido é um perverso escarnecedor. Cumplice de Vênus nos ardis, eles se deleitam com os tormentos que causam às suas vítimas, o que se nota em vários poemas ${ }^{170}$. Horácio aplica o epíteto ridens a Vênus, em poemas em que Cupido trabalha como seu principal assistente seus jogos cruéis, como nessa passagem das Odes, em que o arco frouxo indica que a missão de atingir Europa foi cumprida: "aderat quaerenti perfidum ridens Venus et remisso filius arcu."171 (Enquanto ela se lamentava, Vênus ficava ao seu lado com riso traiçoeiro, e seu filho com o arco afrouxado). Nisbet ${ }^{172}$ observa quão ambíguo é o riso de Vênus nessa passagem, em que ela diverte-se às custas de Europa e, por outro lado, está prestes a revelar o futuro majestoso que a espera.

Vimos em Odes 2.8, que Cupido ${ }^{173}$ ri ao lado da mãe ao despertar a paixão por Barine nos homens. O riso relaciona-se ao seu caráter pueril e lúdico, mas também lembra o Eros sarcástico e zombeteiro de epigramas helenísticos:

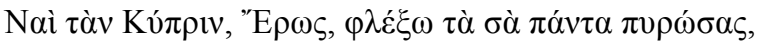

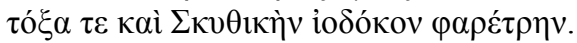

\footnotetext{
165 Hor., Carm. 1.30.6.

${ }^{166}$ Hor., Carm. 2.8.14.

${ }^{167}$ Hor., Carm. 4.13.6-9.

${ }^{168}$ Hor., Carm. 4.1.4-5.

${ }^{169}$ Arkins (1993) "The cruel joke of Venus. In: Rudd (ed.) Horace 2000. A celebration. Essays for the bimillenium. London: Gerald and Duckworth \& Co. Ltd..

${ }^{170}$ Cupido e Vênus rindo: Ov., Am., 1.6.11: risit, ut audirem, tenera cum matre Cupido et leviter 'fies tu quoque fortis' ait.

${ }^{171}$ Hor., Carm. 3.27.67.

172 Nisbet and Hubbard (2004:336).

${ }^{173}$ Ov., Am. 1.1.5, 13 e 25.
} 


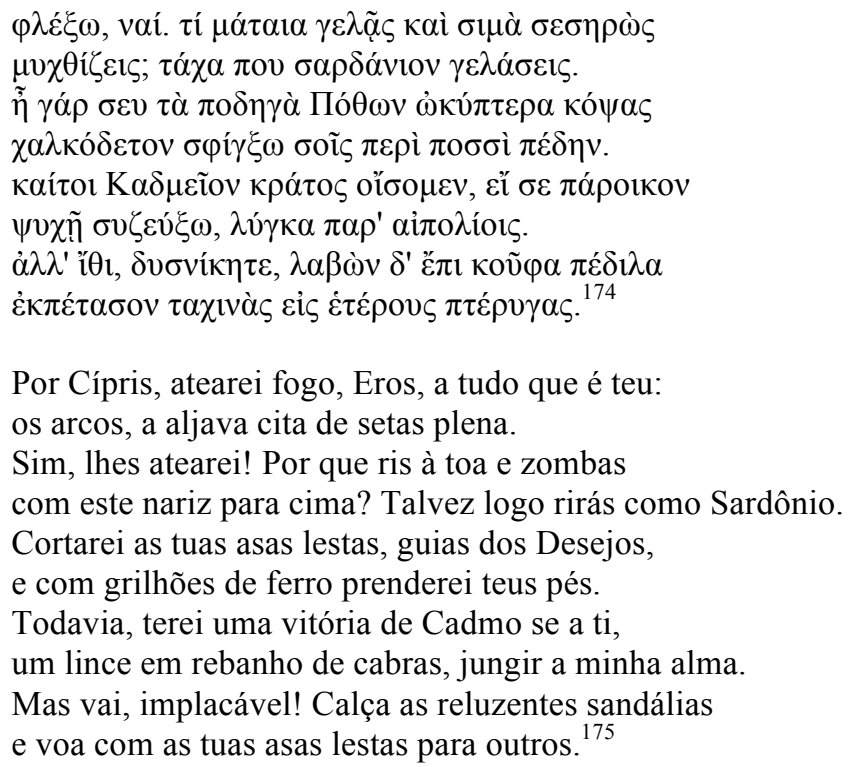

West ${ }^{176}$ ressalta o quanto é familiar, na poesia latina, a imagem de Cupido como braço direito de Vênus, e o divertimento que lhe proporciona desencadear o páthos, como na Eneida ${ }^{177}$, em que o deus imita contente os passos de Iulo, preparando-se para a traição que irá levar a rainha de Cartago à perdição. Esse caráter irreverente do deus o leva a cometer atos que muitas vezes podem surpreender até mesmo sua própria mãe. $\mathrm{O}$ tema de Amor Punido aparece em vasos nupciais da Apúlia ${ }^{178}$ desde o século IV a.C, e também em pinturas de Pompeia, como esta, abaixo. Afrodite, sentada sobre uma rocha, segura o arco e flechas subtraídos do pequeno, que, por sua vez, esconde a face com as mãos, como se estivesse chorando ou envergonhado, e é escoltado por uma figura feminina, que, segundo a autora é identificada como Peitho, a Persuasão, caracterizada como a personificação da comunicação pacífica e convincente, cativando sem constranger e vinculando eros ao logos. O outro Cupido, apoiado nos ombros da mãe e fazendo um gesto com a mão direita, pode ser Anteros, o antagonista de Eros:

\footnotetext{
${ }^{174}$ Meleagro, A. P. 5.179 .

175 Tradução de F. V. Amaral.

${ }^{176}$ West (1995:92).

${ }^{177}$ Vergil, $A$. 1.690 .

${ }^{178}$ Taranto National Archaeological Museum. Inv. 198314. Apulian red-figure nuptial lebes. 360 a.C.
} 


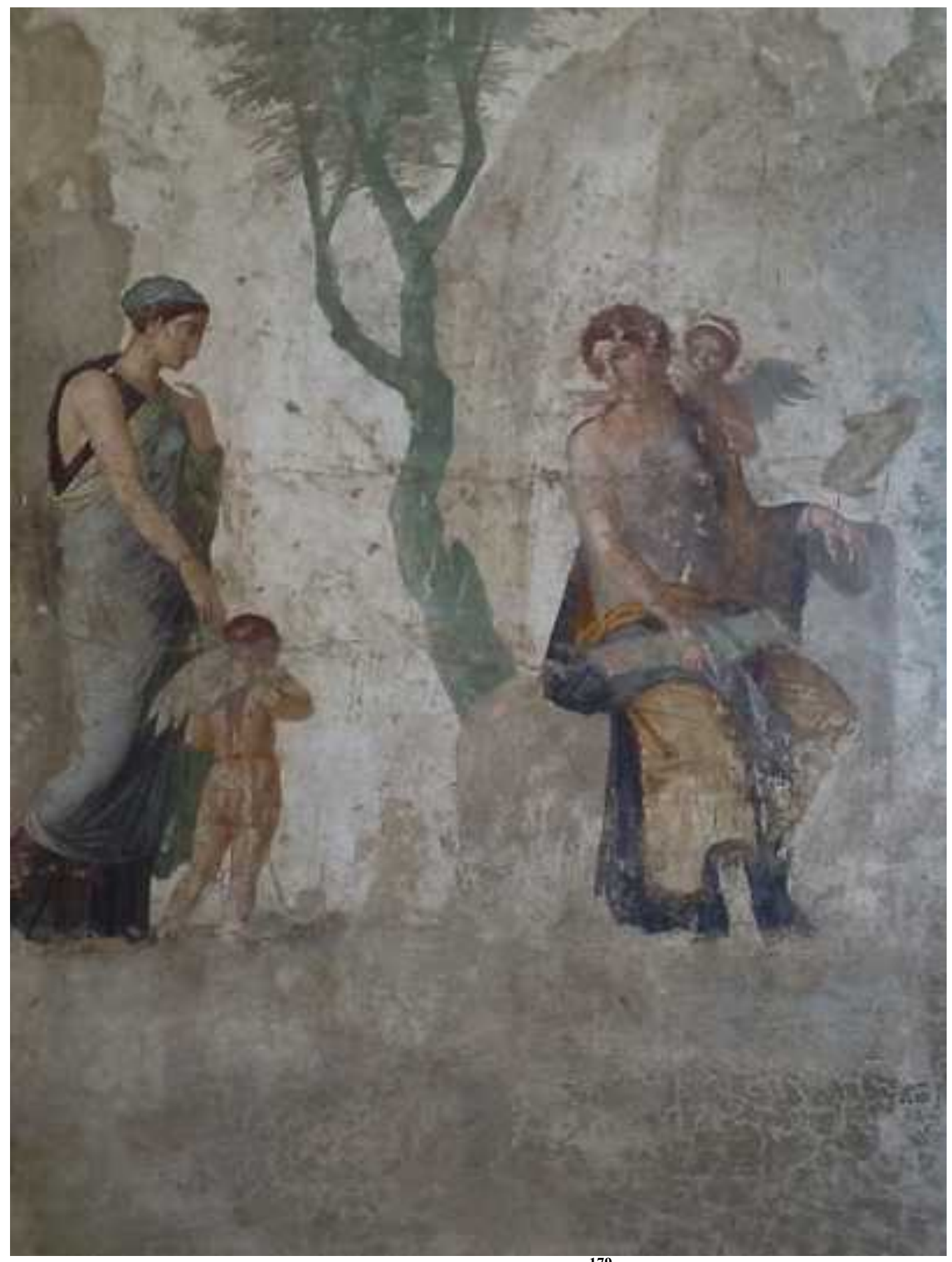

Figura 12. Amor Punido

${ }^{179}$ Museo Archeologico Nazionale di Napoli, Nápoles, Itália. Amore Punito. Inv. 9257. Pompeia. Casa dell'Amore Punito, VII 2, 23, tablino (f), parede Norte. Afresco. Altura: $154 \mathrm{~cm}$; largura: $116 \mathrm{~cm}$. Datação: 1-25 d.C.. 


\section{Número de Cupidos e Cupidos em número}

Além da variedade de nomes para o deus do amor, há também uma variação em número. $\mathrm{O}$ singular é empregado com mais frequência, porém o uso do plural ocorre com os três nomes, Amores, Cupidines e Pueri, uma variação que se repete tanto na poesia como na iconografia. Dependendo do número, podem variar também os papéis. Por exemplo, na tópica militia amoris, sozinho, Cupido pode figurar como comandante de um exército, ou como um "César" triunfante ${ }^{180}$; em grupos, os Pueri agem sob o comando de Vênus ${ }^{181}$, capturando as vítimas do amor. Na pintura parietal abaixo, três deles brincam diante de um altar, sobre o qual pousa uma pomba, ave de Vênus ${ }^{182}$. Já vimos alguns exemplos de pinturas em que Eros porta o cetro da deusa, símbolo de autoridade e poder; nesta, dois deles o disputam, uma atitude que sugere o iocus, ou diversão, que eles proporcionam como membros do séquito de Afrodite ${ }^{183}$ :

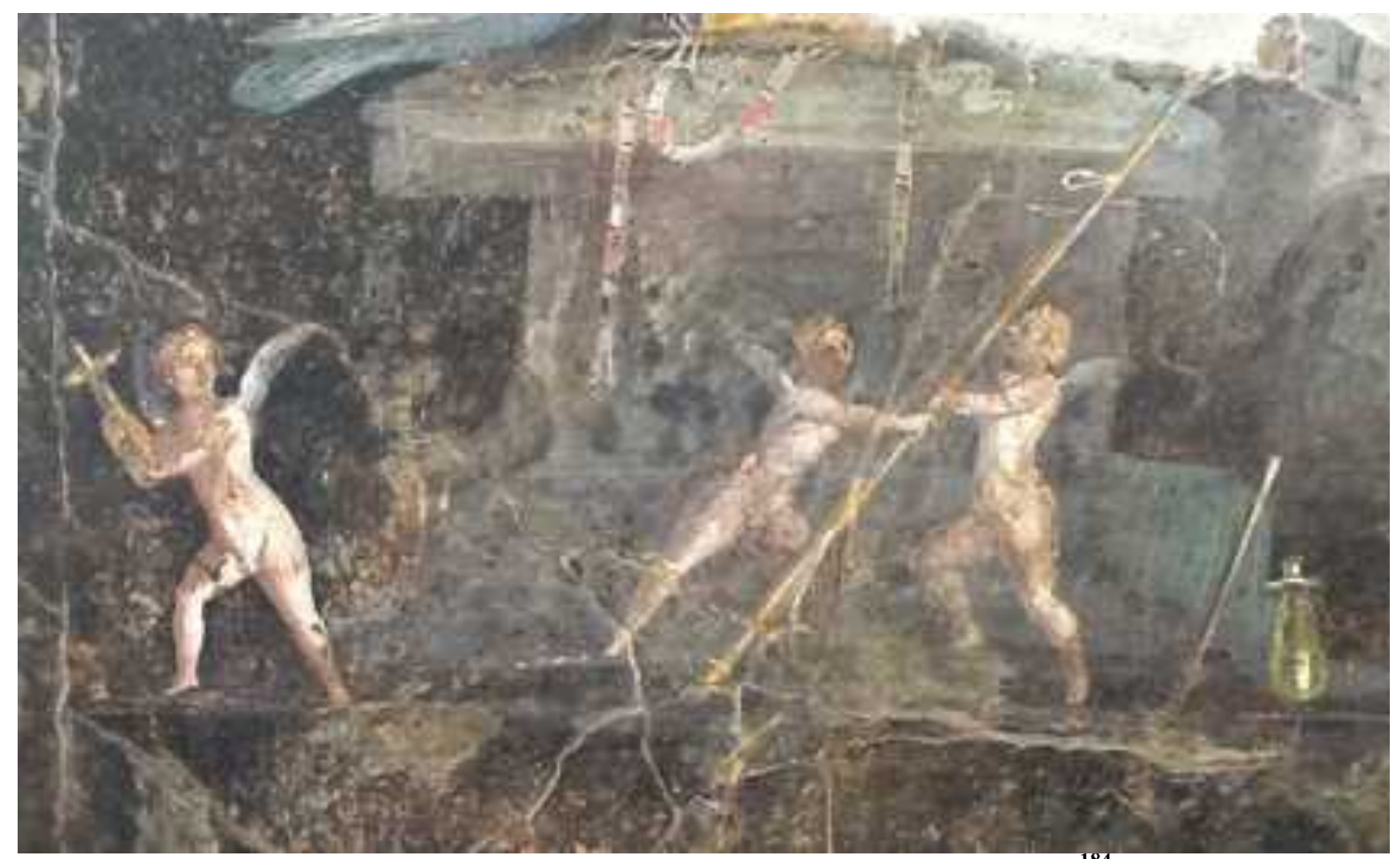

Figura 13. Cupidos brincando com os atributos de Vênus ${ }^{184}$

Rosenmeyer ${ }^{185}$, em seu artigo Eros-Erotes argumenta que os putti grecoromanos são descendentes diretos do Eros de Hesíodo. Em Homero, Eros não aparece

\footnotetext{
${ }^{180}$ Ov., Am. 1.9.

181 Prop. 2.29.a.

182 Sampaolo (2009:106).

${ }^{183}$ Figuras. 1 e 2.

${ }^{184}$ Museo Archeologico Nazionale di Napoli, Nápoles, Itália. Inv. 9194. Alt. Cm 81; largh; cm 92. Portici, villa presso la Reale Scuderia di Portici.
} 
como personificação, e, como sabemos, a menção mais antiga a ele encontra-se na Teogonia, em que, além de ser divindade primordial, faz dupla com Himeros como membro no séquito de Afrodite. Segundo esta autora, por volta do final do século VI a.C., um processo de pluralização de Eros, mais especificamente, a presença de uma multiplicidade de figuras pouco diferenciadas entre si, pode ser observada nas artes, especialmente em vasos áticos. Ao mesmo tempo, na poesia, principalmente a de Píndaro $^{186}$, o termo genérico erotes aparece como uma metáfora para as diversas experiências eróticas, paixões, deleites ou desejos. Além de Píndaro, na Grécia, as mais antigas ocorrências do plural erotes encontram-se em versos de Baquílides ${ }^{187} \mathrm{e}$ Simônides ${ }^{188}$, porém, o uso do singular predomina em outras fontes, como os dramas de Ésquilo ${ }^{189}$, Sófocles ${ }^{190}$ e Eurípedes ${ }^{191}$. Para a autora, Píndaro é responsável pela imagem pluralizada do deus que chega à poesia alexandrina. Por outro lado, no mundo helenístico, a infantilização atrelada à genealogia reforça o caráter individualizado do deus, e nesse momento, ambas as formas, pluralizada e singular, mantinham-se em vigor nas mais diversas artes.

Em Roma, a forma singular é mais comum, embora coexista com o plural, tanto na poesia como em outas artes. Da junção desses dois elementos, o deus como criança e a forma pluralizada, resulta a figura dos putti que proliferam, especialmente, em pinturas parietais de Pompeia como esta, da caça ao cervo, em que o da esquerda empunha uma lança e é acompanhado por um cão e o da direita está próximo a uma lebre:

\footnotetext{
${ }^{185}$ Rosenmeyer (1951:21).

${ }^{186}$ Píndaro. N. 3.30, 8.5, 11.48; frs. 107, 108, 113 Bowra.

${ }^{187}$ Baquílides, fr. 9.73 Snell.

${ }^{188}$ Simônides, fr. 42 Dihel; 126 Dihel. A autoria desses versos ainda é discutida.

${ }^{189}$ Ésquilo, As Suplicantes; Prometeu Acorrentado: 2 ocorrências no plural e 13 no singular.

${ }^{190}$ Sófocles, Antígone: 2 ocorrências no plural e 17 no singular.

${ }^{191}$ Eurípides, Hipólito; As Bacantes: 1 ocorrência no plural e 10 no singular.
} 


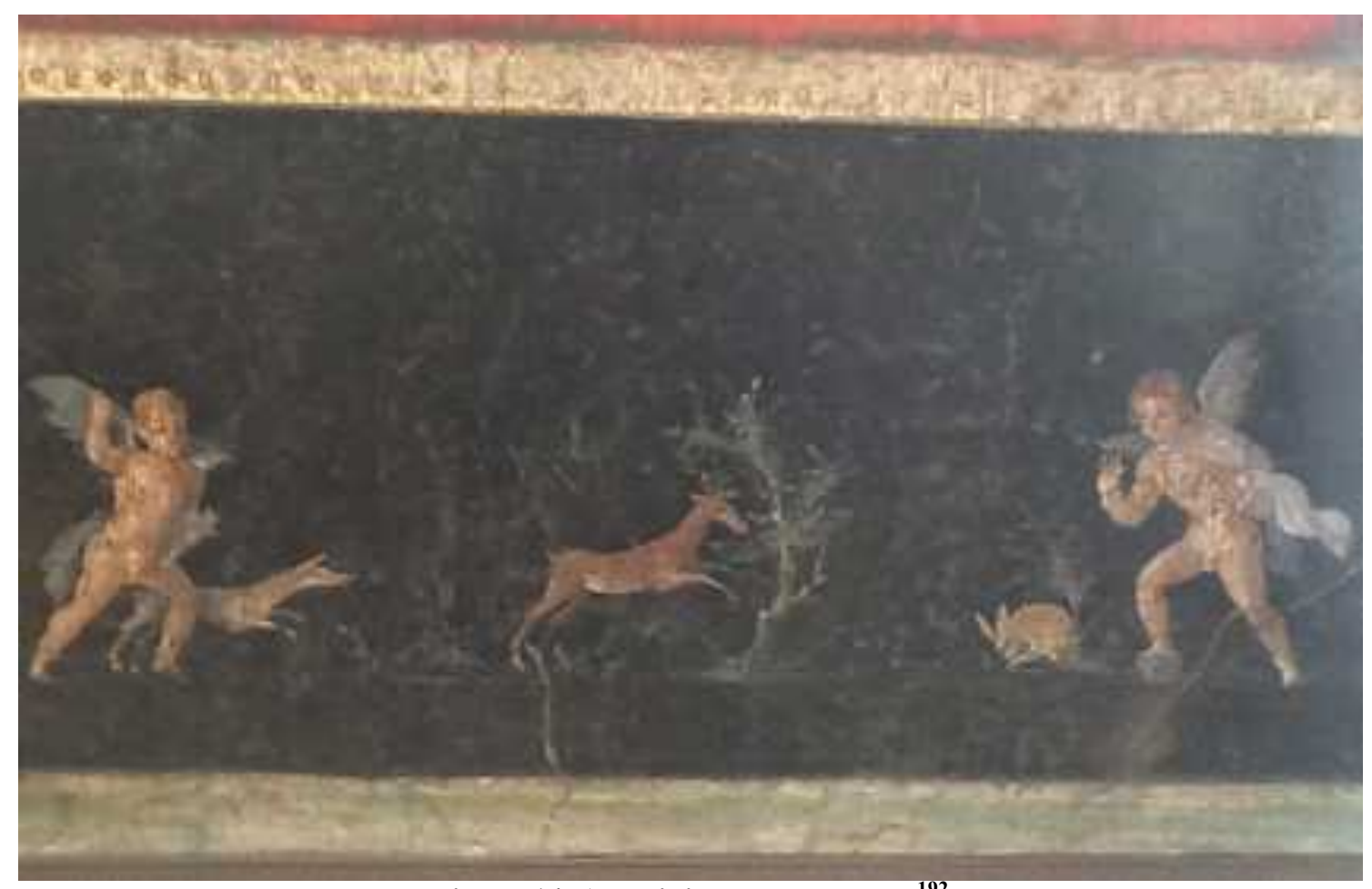

Figura 14. Amorini em cena de caça ${ }^{192}$

Este tema remete à iconografia de um mosaico de Alexandria ${ }^{193}$ do século III a.C. com três Erotes ${ }^{194}$ adultos e armados em semelhante cena, que por sua vez lembra um mosaico de Pela ${ }^{195}$, em que duas figuras heroicas, musculosas e de expressão feroz praticam o mesmo ato. Segundo Westgate ${ }^{196}$, essas posições corporais são comuns em cenas de caça, especialmente de cervo ou leão, ou de batalha, em que o animal é substituído por um guerreiro caído, figurações que remetem ao status aristocrático dessas personagens. Nesta pintura de fundo negro, no lugar dos guerreiros do mosaico de Pela ou dos Erotes adultos do mosaico de Alexandria, figuram Amorini. Os Putti, do mesmo modo que os guerreiros e Erotes dos mosaicos citados, são figuras genéricas que remetem a tipos, sem individualidade ou nomes específicos, cujo papel é mais relevante pela função que desempenham em grupo do que como figura isolada.

Na poesia, Horácio, por exemplo, utiliza duas vezes o plural em uma expressão que se repete nas odes 4.1 e 1.19, mater saeua Cupidinum. Na 1.19, ele associa Vênus, Licença e Baco, um trio de divindades que afeta o poeta, respectivamente, com desejo

\footnotetext{
${ }^{192}$ Museo Archeologico Nazionale di Napoli, Nápoles, Itália. Inv. 9229. Predella. Pompei, VII 6, 28; cubicolo 8. Alt. cm 43. Largh. cm 108; 24-45 d.C.

${ }^{193}$ Stag Hunt. Graeco Roman Museum. Shatby, Alexandria. Inv. 21643. 5.25m X 3.95m. Third century B.C..

${ }^{194}$ Um deles pouco visível em uma parte danificada da obra.

${ }^{195}$ Pella, House I.1. Room C. Mid to Late $4^{\text {th }}-$ early $3^{\text {rd }}$ B.C.

${ }^{196}$ Westgate (1999:23).
} 
sexual, lascívia e embriaguez, levando-o a ter uma recaída por antigos amores. Por outro lado, Quinn ${ }^{197}$ observa que a expressão Mater Cupidinum nesse poema, embora remeta à imagem de Afrodite com seu séquito, comum na arte, lembra também o sentido grego ${ }^{198}$ de mãe dos desejos, uma representação alegórica de um plural poético, que não tem por fim evidenciar um sentido pessoal. A interpretação de cupidines nas Odes de Horácio como substantivo comum, “desejos”, tampouco parece inadequada, uma vez que, a este ponto, entendemos que estas personificações podem dar forma humana a conceitos abstratos e, portanto, também têm por fim simbolizar uma multiplicidade de afetos, paixões ou amores que bem conhecem os apaixonados. Enfim, Vênus é, sem dúvida, uma genetrix de Cupidos, ou progenitora de Desejos, que são seus aliados nas guerras do amor, como podemos notar nos mais diversos exemplos anteriormente citados.

Catulo utiliza as formas singular ${ }^{199}$ e plural de Amor e Cupido. O plural repete-se nos poemas 3 e 13 com a expressão Veneres Cupidines. No 3, ele suplica a esses deuses para que venham lamentar a morte do animal de estimação de sua amada:

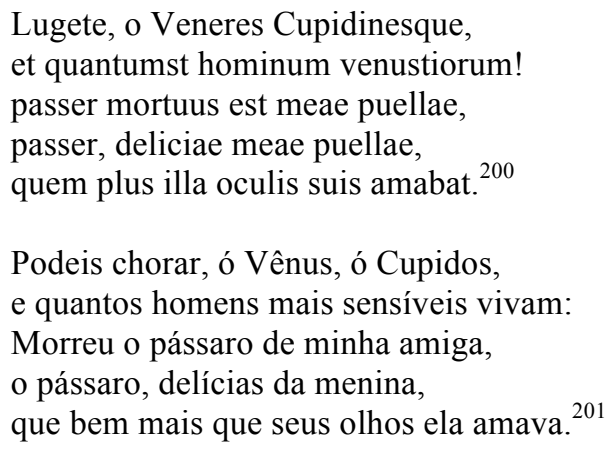

Quinn $^{202}$ analisa o uso dessa expressão por Catulo, sugerindo que a tradição de mais de uma Afrodite parece ter vindo do mundo helenístico, mas também pode ser uma alusão ao Simpósio ${ }^{203}$ de Platão, em que Pausânias defende a tese de que há duas Afrodites, cada qual com o seu Eros: uma delas é Pandêmia, mais jovem, que atende às causas populares; e a outra é uma divindade mais velha e respeitável, Urânia, que inspira um amor de natureza superior.

\footnotetext{
${ }^{197}$ Quinn (1980:162).

${ }^{198}$ Píndaro, fr. 133 Bowra.

${ }^{199}$ Cat., Carm. 45.8 e $17 ; 36.3$.

${ }^{200}$ Cat., Carm. 3.1-5.

${ }^{201}$ Tradução de J. A. Oliva Neto.

202 Quinn (2009:97).

${ }^{203}$ Pl., Sym. 180a-182a.
} 
Quinn observa que Catulo, nos versos iniciais do poema acima, joga com dois usos da palavra uenus, como substantivo comum e nome próprio da personificação. Segundo o autor, na comédia, uenustus geralmente se aplica à mulher ou a Vênus, porém, na poesia de Catulo, o adjetivo, além do charme e da beleza, também tornou-se sinônimo de urbanitas, e geralmente aplica-se ao homem, tal como aparece em 4 das 6 ocorrências da palavra em sua poesia. O sentido, portanto, no verso 2, seria de "todos os homens refinados, charmosos e educados"; mas, inevitavelmente, a presença da personificação no verso 1, elucida mais um sentido, que seria também de "todos os homens que são de Vênus".

No verso 2 da elegia 1.1, Propércio utiliza o termo cupidines, que pode ser interpretado como "desejos", mas também creio ser possível uma tradução como "Cupidos", com letra maiúscula, referindo-se às personificações. Estou utilizando a edição de Goold, que traz o ablativo cupidinibus em minúscula, não referindo-se, portanto, à personificação. Tal escolha, como já dissemos, parte do editor:

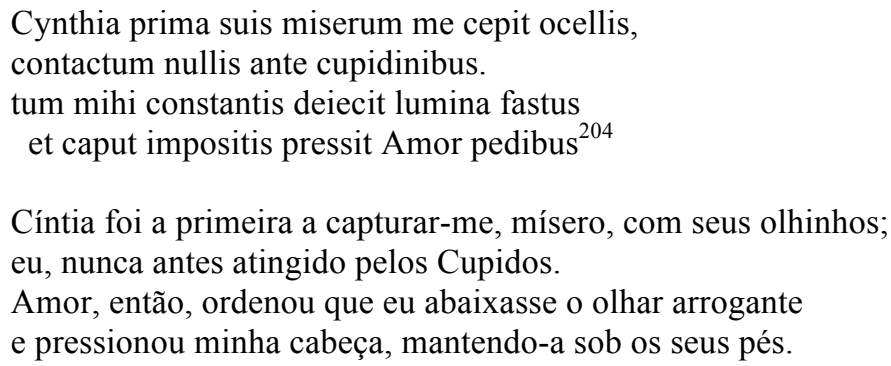

Heyworth $^{205}$ observa que Cupidines, no verso 2, combina-se bem com Amor, no verso 3, respectivamente no plural e no singular, como alusão a uma provável fonte desses versos, que é o epigrama 12.101 da $A$. $P$. de Meleagro, em que aparecem as formas Pothoi e Eros, respectivamente no plural e no singular, um uso que ocorre em diversos outros epigramas desse autor ${ }^{206}$. Nesse epigrama abaixo, particularmente, o poeta, nunca antes vítima dos Desejos, é pela primeira vez capturado pelo olhar de Misco, que pisoteia sua arrogância. No entanto, tal evento não o surpreende, que ressalta o alcance da tirania de Eros, até mesmo sobre Zeus:

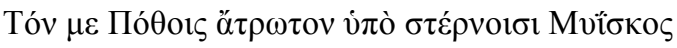

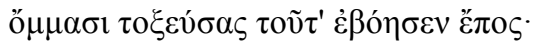

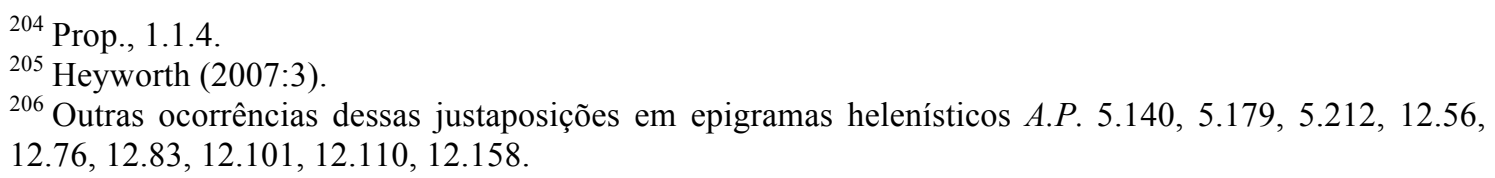




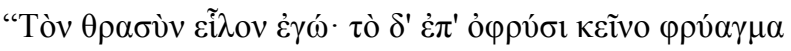

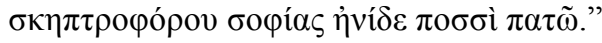

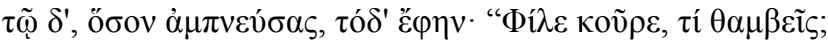

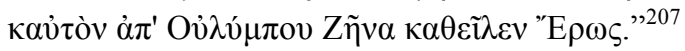

O meu peito invulnerável aos Desejos, Misco

com seus olhos flechou e essas palavras gritou:

"Eu capturei o atrevido. Vê como espezinho sobre aquela

sobrancelha insolente que carrega sabedoria régia".

Mas, tomando fôlego suficiente, isso eu disse: "Caro rapaz,

por que te espantas? Mesmo a Zeus Eros fez descer do Olimpo!",208
\end{abstract}

Tendo observado os diversos exemplos acima, concluímos distinção entre o uso comum e próprio dos nomes de Vênus, Cupido, Amor e Puer na poesia latina envolve uma delicada questão de interpretação e esbarra numa ambiguidade, muitas vezes insolúvel, em que a persona do deus confunde-se com os efeitos por ele causados.

No mundo romano, a tradição grega de Cupidos e Vênus diferentes aparece não só na poesia, como vimos nos exemplos acima, mas também em passagens como estas, abaixo, do De Natura Deorum de Cícero, que mencionam as diversas Vênus e Cupidos conhecidos dos romanos. Ele distingue quatro Vênus:

Venus prima Caelo et Die nata, cuius Eli delubrum vidimus, altera spuma procreata, ex qua et Mercurio Cupidinem secundum natum accepimus, tertia Iove nata et Diona, quae nupsit Volcano, sed ex ea et Marte natus Anteros dicitur, quarta Syria Cyproque concepta, quae Astarte vocatur, quam Adonidi nupsisse proditum est. ${ }^{209}$

A primeira Vênus é filha do Céu e do Dia, cujo templo vimos em Élida; a outra, nascida da espuma, gerou com Mercúrio o segundo Cupido, como sabemos; e a terceira, filha de Júpiter e Dione, casou-se com Vulcano, mas diz-se que Anteros é filho dela com Marte; a quarta, nascida na Síria e em Chipre, e que é chamada de Astarte, casou-se com Adonis, como consta nos textos.

e três genealogias de Cupidos, nascidos de três pais e mães diferentes, incluindo duas Vênus mencionadas acima:

Cupido primus Mercurio et Diana prima natus dicitur, secundus Mercurio et Venere secunda, tertius qui idem est Anteros Marte et Venere tertia. Atque haec quidem $<$ et alia> eius modi ex vetere Graeciae fama collecta sunt. ${ }^{210}$

Diz-se que o primeiro Cupido é o nascido de Mercúrio e Diana, o segundo, de Mercúrio e da segunda Vênus, e o terceiro, que é o mesmo que Anteros, de Marte e

\footnotetext{
${ }^{207}$ Meleagro, A. P. 12.101.

${ }^{208}$ Tradução de F. V. Amaral.

${ }^{209}$ Cic., N. D. 3.59.

${ }^{210}$ Cic., N.D. 3.60.
} 
da Terceira Vênus. Estas e outras lendas foram recolhidas das antigas tradições da Grécia.

Nas duas passagens, o filho da terceira Vênus e de Marte é o mesmo que o grego, fruto de um amor adúltero por Marte. Na poesia latina, normalmente o nome Anteros não é utilizado, mas a genealogia como filho de Marte e Vênus, sim, com uma diferença: Marte não é pai, mas padrasto (uitricus) de Cupido $^{211}$. Esse aspecto de sua genealogia merece atenção especial, e iremos abordá-lo mais detalhadamente quando discutirmos a tópica militia amoris.

\section{Iocus e Cupido: gemini Amores?}

Vimos exemplos em que Afrodite figura acompanhada por dois meninos, como na poesia arcaica de Hesíodo e também em pinturas, como a da Casa de Venus Marina em Pompeia, com o tema do nascimento da deusa. Na estátua abaixo, fabricada no século I a.C em Myrina ${ }^{212}$, o mesmo número de Cupidos acompanha Vênus, que tem os cabelos adornados com um diadema e segura uma ave com a mão esquerda; um dos Cupidos aconchega-se deitado em seu manto do lado direito, e o outro está em pé sob um pedestal à sua esquerda. As curvas são acentuadas tanto no corpo da deusa, descoberto acima da cintura, evidenciando o seu atributo de nutrix; como na veste que a circunda:

\footnotetext{
${ }^{211}$ Ov., Am. 2.9b.

${ }^{212}$ Myrina (Aeolis, Asia Menor, atual Turquia) e Tanagra (Norte da Grécia) foram grandes centros de produção de terracota no período helenístico.
} 


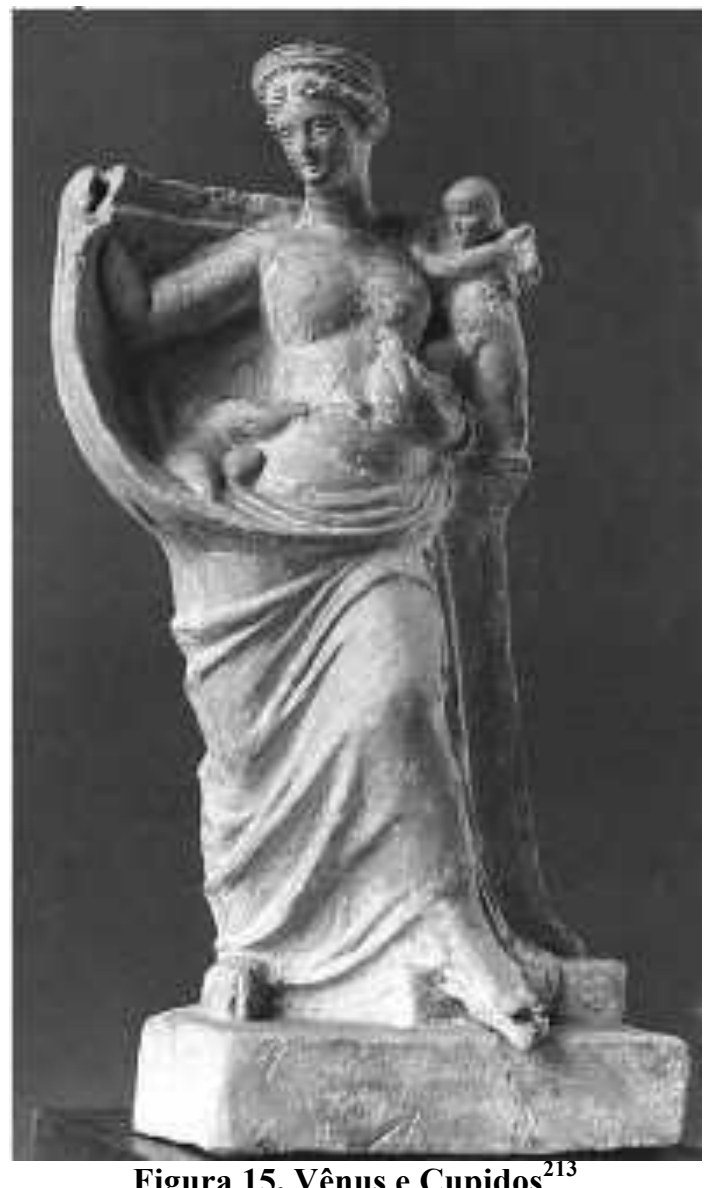

Figura 15. Vênus e Cupidos ${ }^{213}$

A circularidade nos contornos dessa escultura sugere movimento, assim como seguintes versos das Odes de Horácio, em que Iocus ${ }^{214}$ e Cupido gravitam ao redor de Vênus. Neste poema, que assemelha-se a um hino clético, o poeta invoca pela assistência e proteção de vários deuses, entre eles, Vênus com Iocus e Cupido, para resgatar Roma num período turbulento:

cui dabit partis scelus expiandi

Iuppiter? tandem venias precamur nube candentis umeros amictus augur Apollo;

sive tu mavis, Erycina ridens, quam Iocus circum volat et Cupido 215

\footnotetext{
${ }^{213}$ Museu do Louvre. Myrina. Aphrodite. C. 150-100 BC. H. 26.5 cm. Myr. 48. Aphrodite is one of the divinities the most frequently portrayed in terracotta figurines from Myrina. Her iconography takes a variety of forms: she can be a more or less faithful reflection of well-known statue types, can appear with Eros in genre scenes or can refer to more specific practices relating to the cults of the Aeolian city. Aphrodite and Erotes. This Aphrodite is one of a series of half-naked Aphrodites leaning against a pillar (see Myrina 671). The addition of small Erotes romping around in the himation she holds open behind her like a shell, and of the bird in her right hand, confer an anecdotal aspect on the group, similar to the kind of "genre subject" seen in Myr 47. French School of Athens excavations, 1883. Department of Greek, Etruscan, and Roman Antiquities.

${ }^{214}$ Existe a tradução Jogo para o nome Iocus, porém optei por manter o nome em Latim.

${ }^{215}$ Hor., Odes 1.2.29-34.
} 


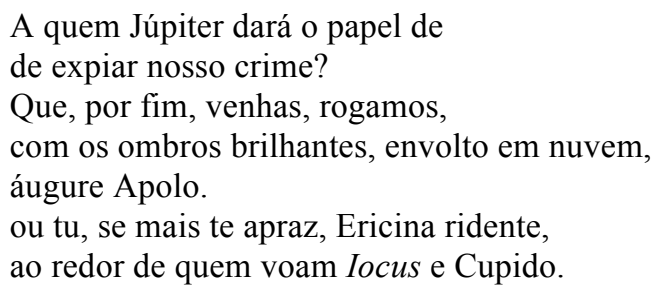

No verso 34, Iocus, voando em círculos em torno da deusa, reproduz uma ação comum dos Erotes. Catulo, por exemplo, refere-se a esse movimento circular numa passagem do carmen 68, em que Cupido movimenta-se em torno de Lésbia, que nesse poema, apesar de infiel, é caracterizada como uma candida diva ${ }^{216}$, quase uma Vênus; e que, portanto, como diz Quinn ${ }^{217}$, "apropriadamente possui um atendente divino": quam circumcursans hinc illinc saepe Cupido fulgebat crocina candidus in tunica. ${ }^{218}$ (amiúde ao seu redor rodopiando de cá para lá, o radiante Cupido resplandecia em sua túnica cor de açafrão.).

Porém, na ode 1.2, poderia Iocus ser considerado como um dos pueri do séquito de Vênus? Essa é a questão de Wlosok ${ }^{219}$, que especifica que Cupido é o nome mais solene do deus, enquanto Iocus não aparece como um nome para Eros em outras fontes, embora possa ser encontrado em comédias de Plauto ${ }^{220}$, ao lado outras personificações eróticas, tais como Amor, Vênus, Voluptuosidade e Ludus. Este último, assim como Iocus, também personifica o jogo ou divertimento.

A moeda abaixo, do final do século I a.C. é outro exemplo da figuração de Vênus acompanhada por dois Pueri, que aqui conduzem sua biga:

\footnotetext{
${ }^{216}$ Cat., Carm. 68.70.

${ }^{217}$ Quinn (2009:392).

${ }^{218}$ Cat., Carm. 68.133-134.

${ }^{219}$ Wlosok (1975: 170).

${ }^{220}$ Plautus, Bac. 114-188:

" $\{$ LYD. $\}$ Quid huc? quis istic habet?

115 \{PIST.\} Amor, Voluptas, Venus, Venustas, Gaudium, Iocus, Ludus, Sermo, Suavisaviatio.

\{LYD.\} Quid tibi commercist cum dis damnosissimis?"
} 

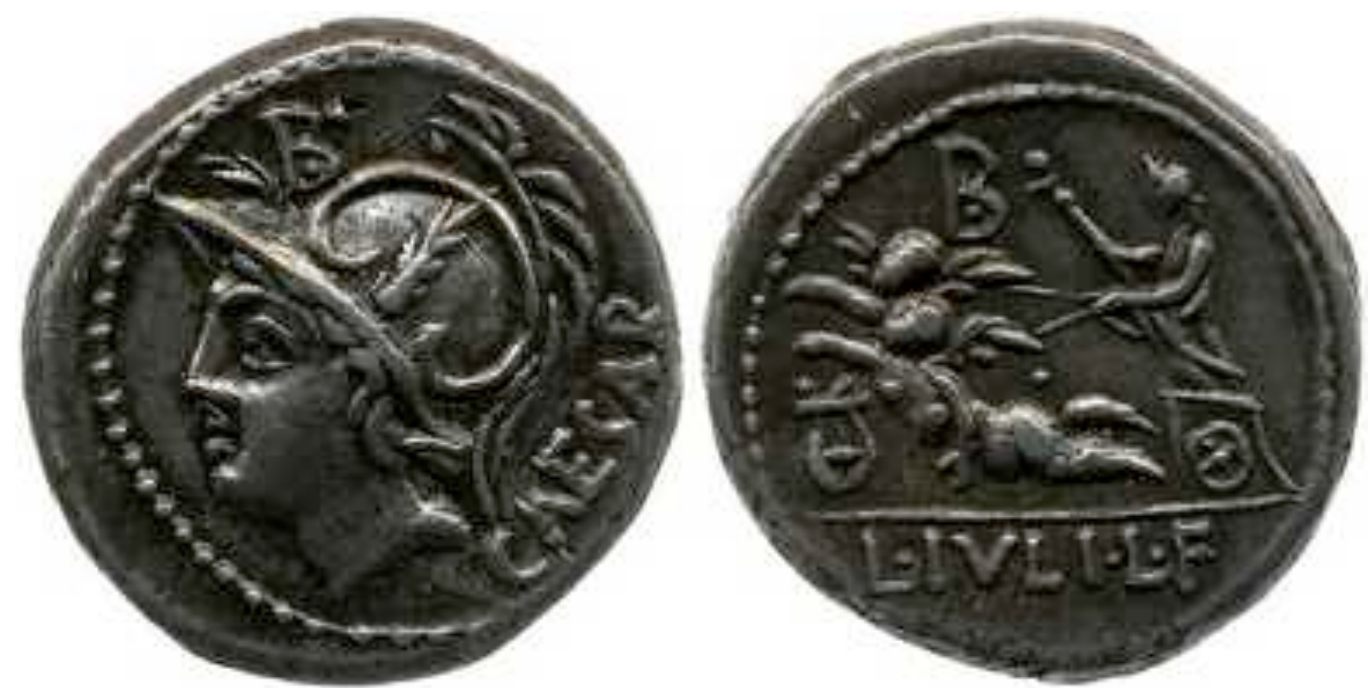

Figura 16. Vênus em biga com Cupidos ${ }^{221}$

Wlosok $^{222}$ questiona se Cupido e Iocus da ode 1.2 podem ser considerados representações análogas à moeda acima, ou então corresponder aos gemini Amores mencionados por Ovídio nos Fastos na invocação a Vênus: 'Alma, fave', dixi 'geminorum mater Amorum ${ }^{223}$ ("Nutriz mãe dos gêmeos Amores, favorece-me,", eu disse). Para Boyle ${ }^{224}$, quem Ovídio chama de "gêmeos Amores" ${ }^{225}$ nessa passagem provalvemente são Eros (Amor) e Anteros (Amor retribuído), as mesmas forças que aparecem em Amores 3.1 como deuses tutelares de sua poesia.

Considerando-se que a ode 1.2 introduz questões concernentes à política de Roma, a figura da Ericina ridente circundada por Iocus e Cupido, no poema de Horácio, à primeira vista parece referir-se a alguma imagem religiosa pertencente a algum templo dessa deusa em Roma, onde havia dois deles dedicados a Vênus Ericina, cujo culto foi trazido do Monte Érix na Sicília. Um deles localizava-se no Capitólio e o outro Extra Portam Colinam, fora dos muros da cidade, e cultivavam diferentes aspectos da deusa.

\footnotetext{
${ }^{221}$ The British Museum. Department: Coins \& Medals. Registration number: R.7949. Bibliographic reference RR1 1405, p.209 Ghey, Leins \& Crawford 2010 320.1.1 RRC 320/1. Object types: coin. Denomination: denarius. Materials: silver . Production place: Minted in Rome. Date: 103BC. Period/Culture: Roman Republican. Authority: Moneyer L Iulius Caesar. State: Roman Republic. Description: Silver coin. Helmeted head of Mars, left (helmet has long crest and plume on each side); behind, inscription; above, control-mark. Border of dots. Venus in biga of Cupids left, holding sceptre in right hand and reins in left hand; above, control-mark; below, lyre; in exergue, inscription. Border of dots. Inscriptions: Inscription Type: inscription. Inscription Position: reverse. Inscription Language: Latin. Inscription Content: L·IVLI $\cdot L \cdot F$. Inscription Type: control mark. Inscription Position: reverse. Inscription Content: B. Inscription Comment: dot in lower part of B. Inscription Type: control mark. Inscription Position: obverse. Inscription Content: B dot to right. Inscription Comment: dot in lower part of B. Inscription Type: inscription. Inscription Position: obverse. Inscription Language: Latin. Inscription Content: CAESAR. Inscription Comment: upwards.

${ }^{222}$ Wlosok (1975:170).

${ }^{223}$ Ov., Fast. 4.1.

${ }^{224}$ Boyle (2000:230).

${ }^{225}$ Ov., Am. 3.15.1; Ov., Ep. 16.203.
} 
O do Capitólio, Aeneadum Genetrix ${ }^{226}$, dedicado por Quinto Fábio Máximo depois da derrota de Trasimeno por volta de 217-215 a.C., era o santuário da ancestral divina dos romanos, patrona das guerras, que mais tarde desdobrou-se em Victrix e Genetrix, ganhando novos templos em Roma; enquanto o outro, mais afastado, era popular e dedicado aos assuntos do amor pessoal. Wlosok observa que, de um lado, Iocus e Cupido poderiam adequadamente figurar no templo popular próximo à Porta Colina, mas por outro lado, o tom do poema sugere que Horácio esteja invocando a Vênus ligada às glórias militares dos romanos. No entanto, não há confirmação de que o poeta esteja referindo-se a alguma estátua de culto em que Iocus figurasse; a probabilidade maior, segundo o Wlosok, é de que ele esteja evocando a figura divina de Vênus, sem necessariamente estar referindo-se a uma imagem específica. Enfim, Vênus com dois companheiros alados era, de fato, uma figuração corrente na arte romana, e nesse sentido restrito, encontramos vários exemplos de gemini Amores, sem poder garantir, no entanto, que algum deles seja uma representação de Iocus.

Se não há como garantir que Horácio esteja referindo-se a Iocus como um dos Erotes de Vênus, qual seria, então, o seu papel ao gravitar ao redor da deusa? Vejamos alguns usos de iocus como conceito abstrato que podem auxiliar na reflexão. De acordo com Nisbet ${ }^{227}$, iocus quer dizer comportamento aprazível ou desfrute (enjoyable behaviour), especialmente no amor. Adams ${ }^{228}$, por sua vez, indica algumas conotações eróticas das formas iocari e iocus, explicando que elas são encontradas em determinados contextos eróticos nos quais seria um pouco excessivo atribuir um sentido físico, como na passagem abaixo, das Epístolas de Horácio, em que iocus refere-se à atitude leve daqueles que estão amando: si, Mimnermus uti censet, sine amore iocisque nil est iucundum, vivas in amore iocisque ${ }^{229}$. (Se, como declara Mimnermo, sem amor e graça não há deleite, viva com amor e graça.) Por outro lado, segundo Adams, há passagens em que iocus parece ter o sentido de ato sexual, como nesses versos de Catulo: ibi illa multa tum iocosa fiebant, quae tu volebas nec puella nolebat ${ }^{230}$ (Lá, então, havia muitos deleites que tu desejavas, e que ela não recusava), nos quais, pela proximidade com uolo e nolo, iocosa pode referir-se a ato sexual. Considerando-se esses exemplos, concluímos que tanto o substantivo comum como a personificação de

\footnotetext{
${ }^{226}$ Vênus como ancestral dos romanos, cf: Lucr., De Rerum Natura 1.1.

${ }^{227}$ Nisbet (1970:31).

${ }^{228}$ Adams (1982:161).

${ }^{229}$ Hor., Epist. 1.6.65-66.

${ }^{230}$ Cat., Carm. 8.6-7.
} 
Iocus associam-se ao jogo e ao gracejo, especialmente em contextos eróticos em que normalmente figuram também os Cupidos.

O conceito de iocus é próximo ao de ludus: ambos aparecem personificados ${ }^{231} \mathrm{e}$ incluem-se no campo semântico do divertimento e do jogo, fundamentais na poesia erótica. Porém, ludus é ligeiramente mais próximo do sentido de ato sexual. De acordo com Adams ${ }^{232}$, em contextos eróticos, o substantivo comum ludus pode indicar as atividades de ambos os sexos no comportamento sexual visto como mutuamente agradável; tanto o substantivo como o verbo são frequentemente usados em referência aos prazeres da juventude. Como exemplo desse uso, em Odes 4.13, por exemplo, Horácio menciona o comportamento inapropriado de Lice, uma velha que bebe e entrega-se aos prazeres como se fosse uma jovem: "ludisque et bibis impudens" 233 (Desfrutas dos prazeres e bebes sem pudor).

Por outro lado, ludus no plural $\left(l u d i^{234}\right)$, pode também referir-se uma série de jogos ou festivais públicos, disputas e exibições que ocorriam no circus ou no teatro. Desse modo, a moeda acima, de Vênus com dois Cupidos conduzindo sua biga, pode representar esses jogos votivos, Ludi Romani, que comemoravam o retorno do exército vitorioso.

Em Odes 1.2, há muito da política romana do período pós-guerra civil em foco $^{235}$. Uma hipótese de Wlosok ${ }^{236}$ para a presença de Iocus nessa ode é sua consonância com o epíteto de Vênus, ridens ${ }^{237}$, que corresponde ao homérico

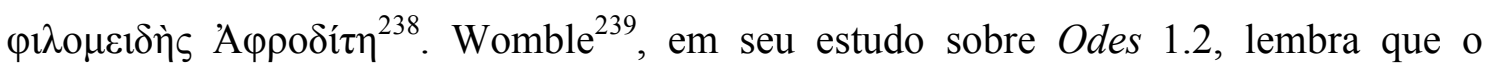
epíteto ridens evoca a relação da deusa com Eneias, a quem é creditada a fundação mítica de seu culto em Érix, no centro da Sicília. Mas, segundo o autor, um aspecto ainda mais importante é que o epíteto Ericina lembra a introdução do culto de Érix em Roma nos dias críticos logo após Canas, seguindo os auspícios da consulta aos Livros Sibilinos. Nesse momento, segundo o autor, Iocus e Cupido talvez pudessem parecer companhias frívolas para esta deusa. No entanto, para Womble, os Erotes que voam ao

\footnotetext{
${ }^{231}$ Ludus personificado, cf. Plaut., Bac. 114-188.

232 Adams (1982:162).

233 Hor., Carm., 4.13.4.

${ }^{234}$ Para um estudo sobre os vários jogos (ludi) que ocorriam em Roma, cf.: Bernstein (2011) “Complex Rituals: Games and Processions in Republican Rome". In: A Companion to Roman Religion. Edited by Jörg Rüpke.

235 Sobre o aspecto político dessa ode, cf. Nisbet (1970:16-40)

236 Wlosok (1975:170).

${ }^{237}$ Para comentários sobre o epíteto ridens cf. Nisbet and Hubbard (2011:31) Comm. on Hor. Odes I.

238 Hom., Il., 3.424.

${ }^{239}$ Womble (1970:12).
} 
redor de Vênus fornecem importante indicação iconográfica de Vênus Felix, a versão de Sulla da Vênus Ericina.

Sula introduziu o culto de Vênus Félix em Pompeia por volta de 80 a.C., durante a colonização romana, quando instalaram-se na cidade famílias de veteranos de guerra que haviam lutado sob o comando do ditador ${ }^{240}$, e a cidade passou a ser chamada de Colonia Cornelia Veneria Pompeianorum. O epíteto dessa Vênus deriva de Felicitas, divindade semelhante a Fortuna, associada à riqueza e à prosperidade, e reverenciada por Sula, que adicionou o agnomen Felix ao seu próprio nome, tornando-se Lucius Cornelius Sulla Felix. O Templo de Vênus foi construído num plano elevado do sudoeste da cidade ${ }^{241}$, alinhado com a parede norte da Basílica, visível de boa parte da cidade e também para os visitantes que entravam pelo Portão Marítimo. Nada restou dessa construção, pois foi extremamente danificada pelo terremoto de 62 d.C.. Moedas e pinturas pompeianas, podem, no entanto, resgatar aspectos de obras, como esculturas e pinturas, que poderiam ser objeto de culto nesse local. Como divindade tutelar de Pompeia, o culto de Vênus mescla-se com o de Fortuna, cujos atributos são o ramo de oliveira, o leme e a proa do navio. Na pintura abaixo, observamos os atributos da Vênus de Sula, de acordo com a interpretação de Swindler ${ }^{242}$ : sua cabeça é adornada por um diadema, ela veste uma longa túnica e um manto, segura um leme e um cetro, e posiciona-se sobre uma quadriga conduzida por elefantes. Três Erotes a acompanham: dois deles, um segurando ramos de palmeira e outro uma guirlanda, pairam no ar como se voassem ao seu redor; enquanto o terceiro, vestindo uma túnica e segurando um espelho, mantém-se em pé ao seu lado, no centro. Os personagens em pé nas extremidades da figura seriam, do lado esquerdo, Fortuna, e, do lado direito, provavelmente Abundância ou Gênio:

\footnotetext{
${ }^{240}$ Swindler (1923:305).

${ }^{241}$ Região VII, 6.

${ }^{242}$ Swindler (1923:304): o autor interpreta a pintura e menciona outros exemplares de Vênus Félix.
} 


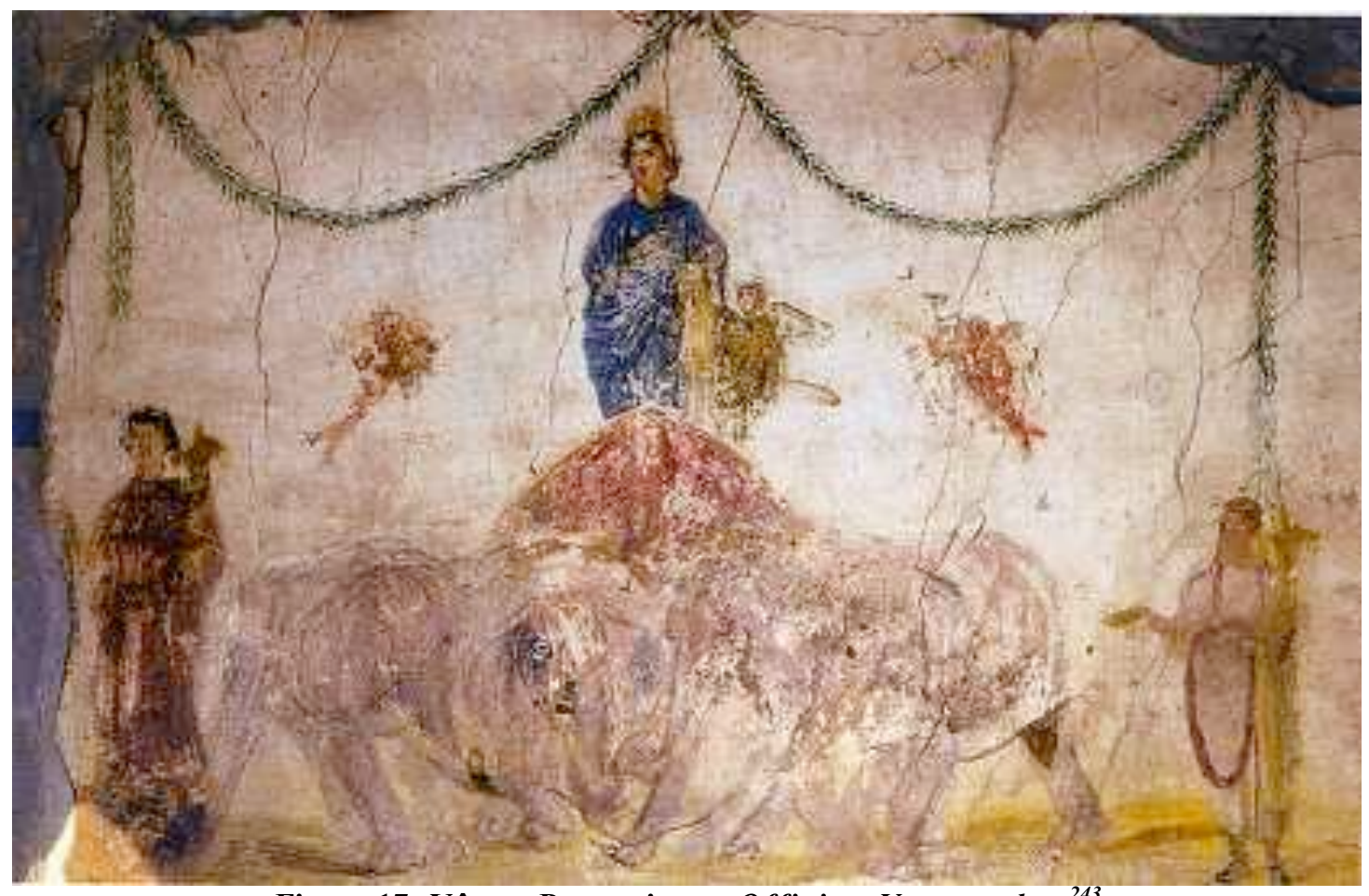

Figura 17. Vênus Pompeiana. Officina Verecundus ${ }^{243}$

Há uma outra pintura semelhante a essa, que pertenceu à fachada de uma loja na Rua da Abundância em Pompeia, em que figuram três Cupidos com Vênus, e no lugar da proa do navio, um pedestal. A composição de Vênus Félix que mais se repete em outras figuras, e que talvez possa reproduzir alguma imagem pertencente ao templo de Vênus em Pompeia, corresponde ao que podemos observar na parte central da pintura acima: a deusa (sobre um pedestal, e não proa) acompanhada por apenas um Cupido.

$\mathrm{Na}$ moeda abaixo, emitida por Sula em sua campanha contra Mitridates ${ }^{244}$, Cupido segura um ramo de palmeira, símbolo das vitórias militares, posicionando-se diante do busto de Vênus:

\footnotetext{
${ }^{243}$ Swindler (1923:303).

${ }^{244}$ Swindler (1923:305).
} 


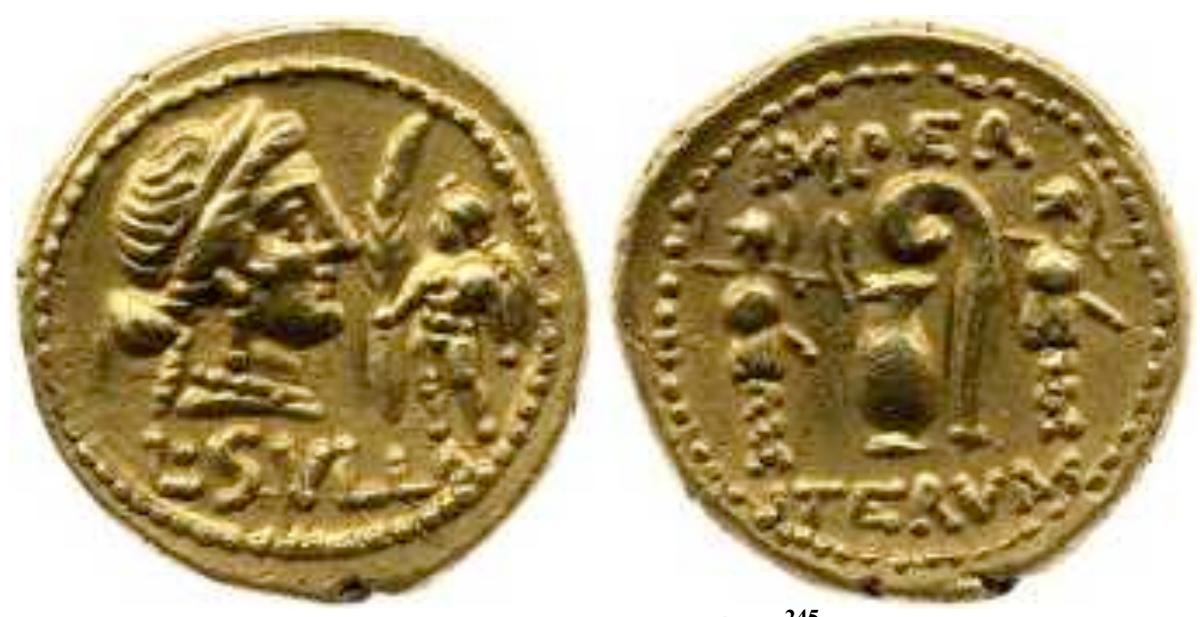

Figura 18. Cupido e Vênus ${ }^{245}$

Templos dedicados a Vênus como defensora das causas militares se multiplicaram em Roma no final da República. Pompeu, no primeiro triunvirato, em 55 a.C., atribuiu a Vênus o epíteto de Victrix, construindo em sua homenagem um templo no Campo de Marte; e César chamou-a Genetrix, construindo seu templo no Fórum em 46 a.C.. O tom marcial na invocação da ode 1.2 evoca a presença épica da VênusEricina-Félix-Victrix em meio ao tumulto da guerra civil.

Os exemplos acima evidenciam que, em contextos religiosos e cívicos em Roma, Cupido apresenta-se sempre como figura acessória, membro do séquito da deusa, e nunca, pelo que se sabe, objeto de um culto independente como havia na Grécia.

\footnotetext{
${ }^{245}$ The British Museum. Department: Coins \& Medals. Registration number: R.8359. Coins and Medals catalogue number: RR2p459.1. Bibliographic reference: RR2 1, p.459 PCR 142 Ghey, Leins \& Crawford 2010 359.1.1 RRC 359/1. Object types coin. Denomination aureus. Materials gold. Production place: Minted in Italy (Mint uncertain, moving with Sulla.) Europe, Italy. Date: 8483BC. Period/Culture: Roman Republican. Authority: Moneyer Lucius Cornelius Sulla. State: Roman Republic. Description Gold coin. (obverse). Head of Venus right, wearing diadem; on right, Cupid holding palm-branch; below, inscription. Border of dots. (reverse) Two trophies; between, jug and lituus; above, inscription; below, inscription. Border of dots. Inscriptions. Inscription Type: inscription Inscription Position: reverse Inscription Language: Latin Inscription Content: ITERVM Inscription Type: inscription Inscription Position: obverse Inscription Language: Latin Inscription Content: L-SVLLA Inscription Type: inscription Inscription Position: reverse Inscription Language: Latin Inscription Content: IMPER Dimensions Weight: 10.75 grammes. Die-axis: 1 o'clock
} 


\section{O papel de Cupido na conspiração épica de Vênus}

A presença de Cupido na Eneida como coadjuvante na conspiração de Vênus ${ }^{246}$ reverbera metáforas bélicas e políticas que evocam imagens como as que acabamos de ver dos Cupidos que acompanham a Vênus cívica, reverenciada nas vitórias militares dos romanos. Vênus articula um plano em que seu filho assume a figura de Ascânio por uma noite e parte para sua épica missão de derrotar a rainha cartaginesa, fazendo-a arder de paixão por Eneias e a iludir-se com a possibilidade de uma futura união. Como sabemos, este é um episódio com final trágico para Dido, e que, por outro lado, devolve o herói para o seu destino épico de fundar um novo lar para os troianos.

\section{A ação de Amor na Eneida}

No episódio que se passa a partir do verso 661 do Livro I, cujas repercussões se notam especialmente no Livro IV, Cupido desempenha uma ação determinante em um momento de reviravolta da narrativa virgiliana, que recai principalmente sobre Dido, provocando alterações em seu êthos, e transformando-a de heroína épica a amante trágico-elegíaca. O "quadro" poético do amor entre Dido e Eneias agrega elementos de outros gêneros, que, no entanto, submetem-se à visão de mundo da ação heroica, unificadora da obra ${ }^{247}$.

A ação de Amor na Eneida consiste, em linhas gerais, em acender em Dido a paixão por Eneias. Para isso, ele assume a figura de Ascânio por uma noite, afim de aproximar-se da rainha e contaminá-la com o seu veneno. É importante considerar que esta ação está subordinada aos desígnios de Vênus, que o envia ao mundo dos mortais com a finalidade de eliminar Dido do caminho do herói, e dessa forma, evitar que possíveis artimanhas de Juno impeçam Eneias de seguir rumo à Itália para fundar um novo lar para os troianos. Desde esse ponto, começa-se a notar a intenção de Virgílio em desviar de Eneias o "fado trágico-elegíaco", que recai quase que totalmente sobre Dido.

Vênus conspira para que a rainha cartaginesa seja tocada pela peste e passe a arder de paixão por Eneias. Nota-se a utilização de loci do amor como ferida e fogo no uso de termos como furens, ignis e incendo:

At Cytherea nouas artis, noua pectore uersat consilia, ut faciem mutatus et ora Cupido

\footnotetext{
${ }^{246}$ Verg., A. 1.683-691.

${ }^{247}$ Vasconcellos (2001:88).
} 
pro dulci Ascanio ueniat, donisque furentem

incendat reginam atque ossibus implicet ignem. ${ }^{248}$

A Citereia no entanto revolve na mente conselhos

e novos planos, no afã de Cupido trocar de aparência

com o doce Ascânio, no rosto e no gesto, por que se insinue

na alma incendiada de Dido e até aos ossos seu fogo alimente. ${ }^{249}$

Amor é peça fundamental para a efetivação do plano, pois nele reside a potência (mea magna potentia ${ }^{250}$ ) e a força (uis) de Vênus:

ergo his aligerum dictis adfatur Amorem:

'nate, meae uires, mea magna potentia, solus

nate patris summi qui tela Typhoëa temnis,

ad te confugio et supplex tua numina posco. ${ }^{251}$

Tresnoitada a pensar, por fim conjura

O alígero Cupido: "Ó filho, esteio

Único e meu poder, que as soberanas

Armas Tiféias menosprezas, filho,

És meu refúgio, teu favor imploro.", 252

Contra Dido, ela utilizará principalmente o fogo, uma das mais poderosas armas do filho:

quocirca capere ante dolis et cingere flamma

reginam meditor, ne quo se numine mutet,

sed magno Aeneae mecum teneatur amore. ${ }^{253}$

Quero vencê-la em seu próprio arraial e inflamar a Rainha

de ardente amor, sem que nume nenhum transmudá-la consiga

e a mim se prenda por meio do afeto que a Eneias eu voto. ${ }^{254}$

A deusa subtrairá o menino Iulo por uma noite, que será levado para descansar em sono profundo na Citera ou no bosque Idálio, enquanto Amor assume o seu lugar. Ela ensina ao filho as estratégias do ataque traiçoeiro à rainha, que se dará em meio a um banquete. Aconchegado no colo de Dido, por meio de abraços e beijos, ele deverá transmitir o venenoso fogo abrasador, que despertará um afeto intenso:

\footnotetext{
${ }^{248}$ Verg., A. 1.657-660.

249 Tradução de C. A. Nunes. Na tradução de Odorico Mendes: "Nova traça urde a Cípria, alvitres novos; que o Amor no meigo Iulo transformado, com os dons nossos ossos da rainha infiltre insano fogo."

${ }^{250}$ Ov., Met. 5.366: 'arma manusque meae, mea, nate, potentia'

${ }^{251}$ Verg., A. 1.663-666.

${ }^{252}$ Tradução de Odorico Mendes.

${ }^{253}$ Verg., A. 1.673-675.

${ }^{254}$ Tradução de C. A. Nunes.
} 
ut, cum te gremio accipiet laetissima Dido regalis inter mensas laticemque Lyaeum, cum dabit amplexus atque oscula dulcia figet, occultum inspires ignem fallasque ueneno. ${ }^{255}$

Pois, quando Dido alegríssima, contra o seu peito apertar-te durante o régio festim, o inebriante perfume do néctar, e te cobrir de dulcíssimos beijos e ternos amplexos, fogo invisível lhe inspires com teus enganosos venenos. 256

Essa ação acarreta consequências determinantes da trajetória de Dido, e, assim, é importante considerar de que modo o seu êthos se modifica. Eneias, que também faz parte do jogo estabelecido por Cupido, por sua vez, participa do episódio de maneira mais passiva e distante: ele é o objeto da paixão - o amado -, enquanto Dido assume o papel de protagonista - a amante por excelência - dando voz ao páthos amoroso.

\title{
Êthos: Amor assimila a figura de Ascânio
}

É comum, na poesia latina, a assimilação da figura de um mortal por um deus. $\mathrm{Na}$ Eneida, é dessa forma que Amor irá interagir com Dido, assimilando a forma de Ascânio, o filho de Enéias, para levar a cabo o plano de Vênus:

\author{
tu faciem illius noctem non amplius unam \\ falle dolo et notos pueri puer indue uultus ${ }^{257}$ \\ Por uma noite somente, não mais, a figura de Ascânio \\ para isso assume; menino como ele, seu todo assimila. ${ }^{258}$
}

Cupido e Ascânio têm uma característica em comum, ambos são crianças (pueri), porém o deus deverá assumir a face (facies) e a figura (vultus) de Iulo para assimilar o seu todo. Para completar, a mãe o instrui a despir-se de suas asas e a imitar os passos do menino, ordens que ele acata contente:

Paret Amor dictis carae genetricis, et alas Exuit, et gessu gaudens incendit Iuli. ${ }^{259}$

No mesmo ponto Cupido obedece aos conselhos maternos; das asas despe-se e os passos imita contente de Iulo. ${ }^{260}$

\footnotetext{
${ }^{255}$ Verg., A. 1.685-689.

${ }^{256}$ Tradução de C. A. Nunes.

${ }^{257}$ Verg., A. 1.683-684.

258 Tradução de C. A. Nunes.

${ }^{259}$ Verg., A. 1.689-690.

${ }^{260}$ Tradução de C. A. Nunes.
} 


\title{
Amor como ferida e fogo
}

Já falamos sobre a metáfora do amor como fogo que faz crescer o desejo nos jovens, nas Odes de Horácio. Na Eneida, Cupido irá utilizá-lo, não só para incitar o desejo, mas também para destruir a rainha de Cartago. Com fogo, ele preenche a alma vazia de Dido, riscando a imagem de Siqueu de sua memória e acendendo a chama do amor por Eneias em seu desiludido coração:

\author{
at memor ille \\ matris Acidaliae paulatim abolere Sychaeum \\ incipit et uiuo temptat praeuertere amore \\ iam pridem resides animos desuetaque corda. ${ }^{261}$ \\ Aos pouquinhos o aluno de Vênus \\ procura a imagem riscar de Siqueu, e vivaz labareda \\ numa alma fria acender, esquecida de tais sentimentos, \\ num coração desafeito a bater de concerto com outro. ${ }^{262}$
}

Nota-se que o fogo, como arma de destruição, está presente na conspiração de Vênus desde o início, e ao longo de toda trajetória de Dido, apresentando-se também no símile da corsa e no final do Livro IV, quando Dido, abandonada por Eneias, deseja para toda a raça odiada dos Dardânios ${ }^{263}$ uma vingança que se efetue com chama e ferida, da qual nem mesmo Ascânio deveria ser poupado ${ }^{264}$. Além disso, pelo fogo e pela chaga ${ }^{265}$, Dido se consumiu de paixão e encontrou a morte:
at trepida et coeptis immanibus effera Dido sanguineam uoluens aciem, maculisque trementis interfusa genas et pallida morte futura, interiora domus inrumpit limina et altos conscendit furibunda rogos ensemque recludit Dardanium, non hos quaesitum munus in usus. ${ }^{266}$
Trépida e em fera empresa encarniçada, Vibrando olhos sanguíneos e às trementes

\footnotetext{
${ }^{261}$ Verg., A. 1.719-722.

262 Tradução de C. A. Nunes.

${ }^{263}$ Ovídio (Ep., 7.75-78) atenua o discurso de Dido, eliminando alguns lugares-comuns do gênero épico de sua fala. Desse modo, o discurso concentra-se mais no conflito amoroso da personagem, suprimindo a dimensão histórica, como o ódio contra povos - os dardânios - e gerações futuras - na figura do pequeno Iulo. A ira de Dido é direcionada exclusivamente à figura do amante, ao qual ela a atribui toda a culpa pelo seu desespero: "haec minus ut cures, puero parcatur Iulo! te satis est titulum mortis habere meae. quid puer Ascanius, quid di meruere Penates? ignibus ereptos obruet unda deos?" (Embora pouco te importes com isso, que o menino Iulo seja poupado! É suficiente que tu sejas o culpado pela minha morte. Porque o menino Ascânio, porque os deuses Penates mereceriam isso? Salvos do fogo, serem destruídos pelas ondas?)

${ }^{264}$ Verg., A. 4.601-602.

${ }^{265}$ Para uma discussão sobre essas tópicas, cf. Vasconcellos (2001:235).

${ }^{266}$ Verg., A. 4.642-647.
} 
Faces de nódoas salpicada, o interno

Claustro penetra, pálida a rainha

Já a futura morte, e furibunda

Sobe à fogueira, o Tróico ferro despe,

Dom não obtido para tal crueza. ${ }^{267}$

$\mathrm{Na}$ última cena entre Dido e Eneias, no Hades, ele a vê ainda marcada pela ferida que a vitimou: inter quas Phoenissa recens a uulnere Dido errabat silua in magna $^{268}$ (No bando, fresca a chaga, errava a Tíria nos desvios do bosque ${ }^{269}$ ); e tenta, em vão, estabelecer diálogo com a infeliz rainha, mencionando a morte pela espada:

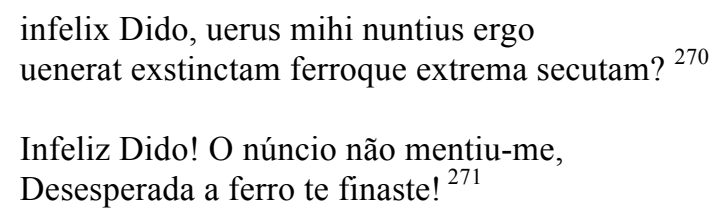

\section{Páthos: as afecções desencadeadas por Amor}

Cupido atua como veículo da atração sexual, como um elo de ligação, que na forma de Ascânio, representando o papel de filho de Eneias, simboliza essencialmente um produto do amor, que acaba tornando-se um incentivo ao amor para Dido, que sonha em formar família com Eneias e assumir o papel de mãe adotiva do menino. Rudd ${ }^{272}$ nota como seria tentador para uma rainha sem filhos como ela adotar Iulo, que poderia tornar-se herdeiro do legado cartaginês e evitar a extinção de sua estirpe. Ignorando os ardis de Vênus, ela se entrega ao poder de fogo de Cupido, que despertará o seu páthos amoroso.

No momento em que Cupido-Ascânio é visto pelos convivas no banquete, ele impressiona a todos, especialmente a rainha, o seu alvo. Envolto em um manto de folhas de acanto amarelo, ele causa admiração com sua forma e brilho divinos (flagrantis uultus); e a rainha, sem saber que se trata de um deus, o devora com os olhos, sendo imediatamente afetada pela peste. Segundo Feeney $^{273}$, esta é a cena mais familiar da

\footnotetext{
${ }^{267}$ Tradução de O. Mendes.

${ }^{268}$ Verg., A. 6.450-451.

${ }^{269}$ Tradução de O. Mendes

${ }^{270}$ Verg., A. 6.456-458.

271 Tradução de O. Mendes.

${ }^{272}$ Rudd (1990) “Dido’s culpa”. In: Harrison (ed.) Oxford Readings in Virgil. Oxford: Oxford University Press.

${ }^{273}$ Feeney (1990:181) "The taciturnity of Aeneas". In: Harrison (ed.) Oxford Readings in Virgil. Oxford: Oxford University Press.
} 
Eneida, no sentido de simular uma situação doméstica com a presença de pais e filhos em um momento de afeição; no entanto, esta é, ao mesmo tempo, uma das cenas mais sinistras, pois marca o momento em que Dido dá o primeiro passo para sua destruição:

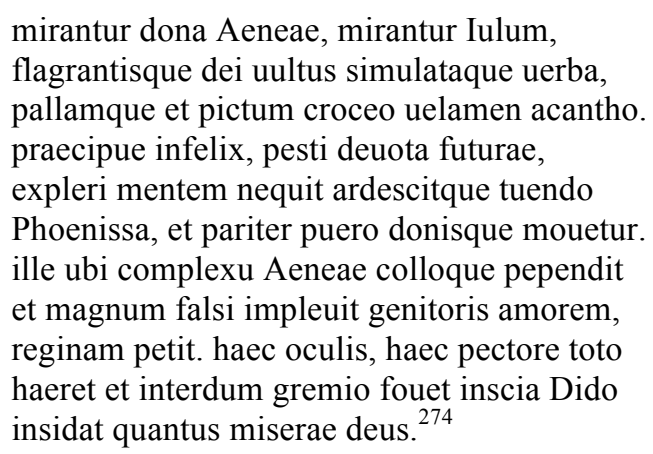

Pasmam dos raros presentes de Enéias, dos toques do belo rosto de Ascânio, seu brilho divino, as palavras fingidas, e o manto enfeitado de folhas de acanto amarelo. Principalmente a rainha infeliz, já tocada da peste que há de abrasá-la, não cansa de olhá-lo, a um só tempo abalada pela influição do menino e os presentes recebidos.

Este, depois de pender algum tempo do colo de Eneias, e de inundar de ternura o imo peito do pai presuntivo vai para Dido, que nele se embebe e o devora com os olhos, de quando em quando apertando-o no peito - coitada! - inconsciente da divindade que a abrasa." 275

O vocábulo pestis evidencia o amor como uma patologia cujos efeitos são graves, e podem até mesmo levar à morte, tal como encontramos na Eneida. Ela é desencadeada pelo veneno de Cupido, que penetra nas veias causando o ardor e o furor avassaladores. Muito antes que Dido perceba, ela é infetada por esse mal que a consome até levá-la à loucura e à morte, anunciado nessa passagem acima. A paixão como doença é um tópos amplamente utilizado pelos poetas latinos. Catulo diz: "Eripite hanc pestem perniciemque mihi" ${ }^{276}$ (Arrancai de mim esta peste e esta desgraça).

\section{As transformações no êthos da rainha}

O êthos de Dido sofrerá diversas alterações em decorrência da ação de Cupido: ao cair presa de um amor destrutivo, sua persona passa a apresentar aspectos líricos, iâmbicos e, principalmente, trágicos e elegíacos. Mas, antes desse episódio, nas palavras de Vênus em diálogo com Eneias, o êthos da rainha apresenta características distintas, que a colocam no mesmo plano dos mais nobres personagens épicos, tal como Eneias,

\footnotetext{
${ }^{274}$ Verg., A. 1.709-719.

275 Tradução de C. A. Nunes.

${ }^{276}$ Cat., Carm. 76.20.
} 
uma vez que ela é exilada, fundadora de uma cidade e líder de um povo ${ }^{277}$. A nova face de Dido começa a delinear-se a partir do momento em que ela passa a sofrer os efeitos do veneno de Amor, vivenciando em um estado de "embriaguez amorosa", que a deixa excitada e falante:

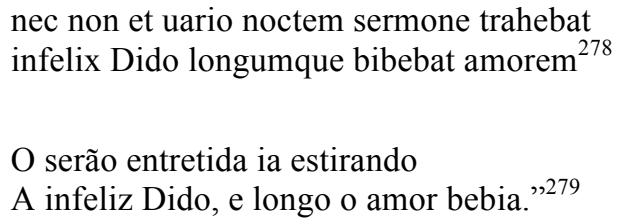

E, logo no início do livro IV, a amante ferida (saucia cura), começa a manifestar os sintomas da doença, desconectando-se do mundo exterior, e revolvendo dia e noite na mente a imagem do herói:

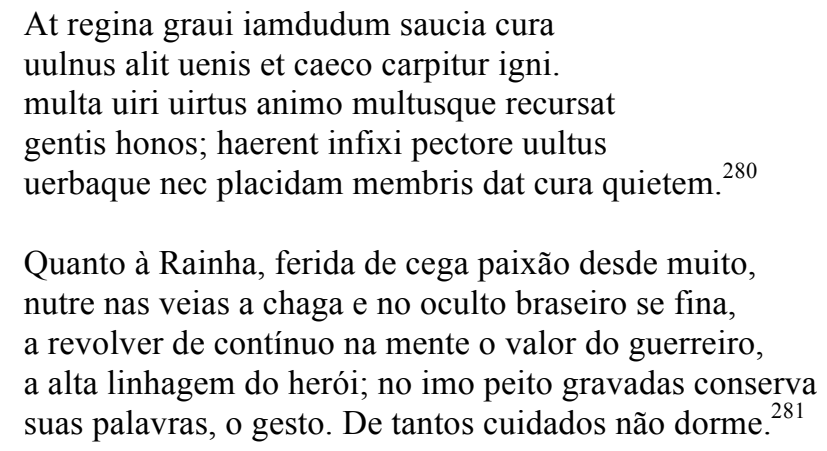

Presa dessa cega paixão, Dido passa a manifestar os signa amoris: inquieta e em estado de excitação permanente, ela é tomada por um furor que a aliena de seu papel social e a transforma em uma escrava do amor, entregue à insânia ${ }^{282}$. Assim, a rainha desvia-se de suas atribuições, como diz Vasconcellos ${ }^{283}$, "negligenciando a tarefa heroica que lhe incumbia - a construção de Cartago e o governo de seu povo", e passa a caminhar na direção inversa, mergulhando numa paixão sem futuro.

O texto caminha no sentido de dar ênfase à paixão do ponto de vista da personagem feminina. Nota-se que Eneias, dentro do jogo erótico, não apresenta êthos de amante elegíaco; ao contrário, é Dido quem assume essa posição: é ela quem é

\footnotetext{
${ }^{277}$ Verg., A. 1.364-370.

${ }^{278}$ Verg., A. 1.748-749.

279 Tradução de O. Mendes.

${ }^{280}$ Verg, A. 4.1-5.

${ }^{281}$ Tradução de C. A. Nunes.

${ }^{282}$ Vasconcellos (2001: 241).

${ }^{283}$ Vasconcellos (2001:255).
} 
misera, infelix, saucia cura, e nesse sentido, sua história assemelha-se à de outras heroínas abandonadas. O adjetivo infelix acompanha a personagem desde o Livro I, antecipando a infelicidade amorosa de Dido:

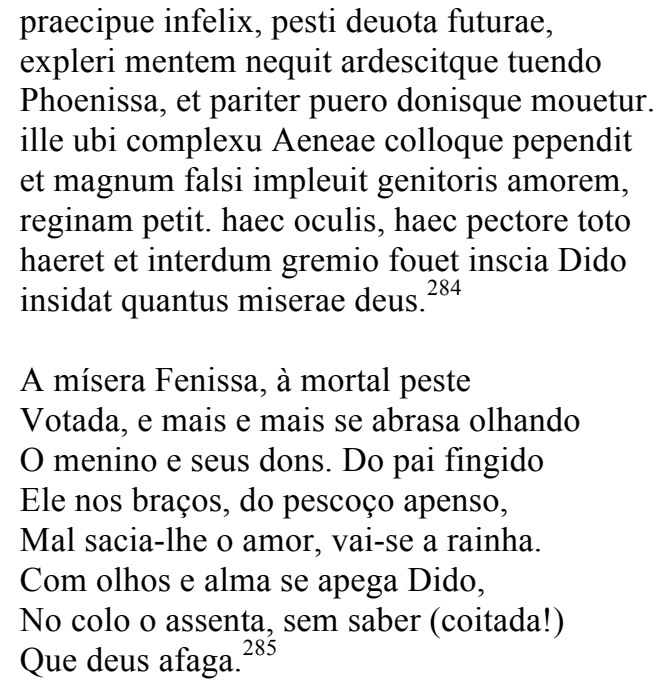

A amante misera lamenta-se pela paixão infeliz e a escravidão aos afetos incontroláveis, um tópos amplamente utilizado na poesia elegíaca augustana, em que o lamento é expresso em primeira pessoa pelo poeta-amator. Dido ressoa essa voz elegíaca, ao dizer: "quando aliud mihi iam miserae nihil ipsa reliqui"286 ("Misera! Pois perdi tudo, sem nada ter me reservado" ${ }^{, 287}$ ).

O caráter de Dido assemelha-se a outras amantes abandonadas e infelizes como a Medeia de Eurípides e de Apolônio, e a Ariadne de Catulo ${ }^{288}$. Ela assemelha-se à Ariadne do poema $64^{289}$ de Catulo, uma vez que ambas são amantes de heróis fundadores de cidades e consideram-se miserae por estarem afetadas pelo ardente furor da paixão. As queixas de Dido contra Enéias ${ }^{290}$ remetem às de Ariadne contra Teseu ${ }^{291}$ : ambas qualificam o amado como pérfido ${ }^{292}$, pois creem ter firmado contrato tácito, o

\footnotetext{
${ }^{284}$ Verg., A. 1.712-719.

285 Tradução de O. Mendes.

${ }^{286}$ Verg., A. 4.315.

${ }^{287}$ Tradução de de C. A. Nunes.

${ }^{288}$ Para comparações entre essas personagens, cf. Fulkerson (2005).

${ }^{289}$ Cat., Carm. 64.196-197.

${ }^{290}$ Verg. A. 4.305-366.

${ }^{291}$ Cat., Carm. 64.132-133.

292 Também nas Heróides (Ov., Ep. 7.57-60), um dos principais argumentos de Dido contra Eneias é a alegação de quebra da fides - o pacto de fidelidade -, uma falta grave para os romanos. Na Eneida, Eneias contra-argumenta, alegando nunca ter jurado fidelidade a Dido (Virg., A. 4.338); já, na Epístola VII, o argumento de Dido, unilateral, prevalece, uma vez que não há refutação do acusado. Ela sugere, ainda,
} 
qual foi quebrado; e ambas declaram que desejariam jamais ter conhecido o amante, lamentando-se da crueldade do abandono ${ }^{293}$.

A pintura cujo tema é o abandono de Ariadne, abaixo, pertenceu à Casa de Meleagro, onde havia uma outra pintura com o tema do abandono de Dido ${ }^{294}$, provavelmente uma justaposição intencional, pois sabemos da semelhança entre essas duas personagens na poesia. Vestindo uma clâmide e segurando um leque ${ }^{295}$ com a mão esquerda, Cupido imita a expressão lamentosa de Ariadne, enxugando as lágrimas com a mão direita, como um cúmplice do páthos da heroína. A figura alada atrás de Ariadne, segundo Sampaolo ${ }^{296}$, é Nêmesis, uma divindade associada a aspectos da justiça, da vitória e do destino, que aponta com a mão direita para o barco de Teseu, enquanto a esquerda repousa sobre ombro de Ariadne:

uma punição para Eneias: morrer afogado, uma vez que o mar, lugar onde nasceu a Citereia, mãe dos Amores, não é bom lugar para quem afronta o pacto de fidelidade, inocentemente supondo que esses deuses possam estar do seu lado: "nec violasse fidem temptantibus aequora prodest; perfidiae poenas exigit ille locus, praecipue cum laesus amor, quia mater Amorum nuda Cytheriacis edita fertur aquis." (Nem quem tenha violado o pacto de fidelidade deve lançar-se ao mar agitado; esse lugar cobra o preço aos infiéis, principalmente quando o amor foi ferido, porque a mãe dos Amores, dizem, emergiu nua das águas de Citera).

${ }^{293}$ Verg., A. 4.311 (crudelis) e 661 (crudelis ... Dardanus); Catulo, Carm. 64.136.

${ }^{294}$ Museo Archeologico Nazionale di Napoli, Nápoles, Itália. Inv. 8898. Didone abbandonata. Pompei, Casa di Meleagro, VI 9, 2.13, atrio (2), parete nord.

${ }^{295}$ Leque de folha de lótus. Sobre o leque como atributo de Vênus, cf. Beeson (1995:5).

${ }^{296}$ Sampaolo (2009:300). 


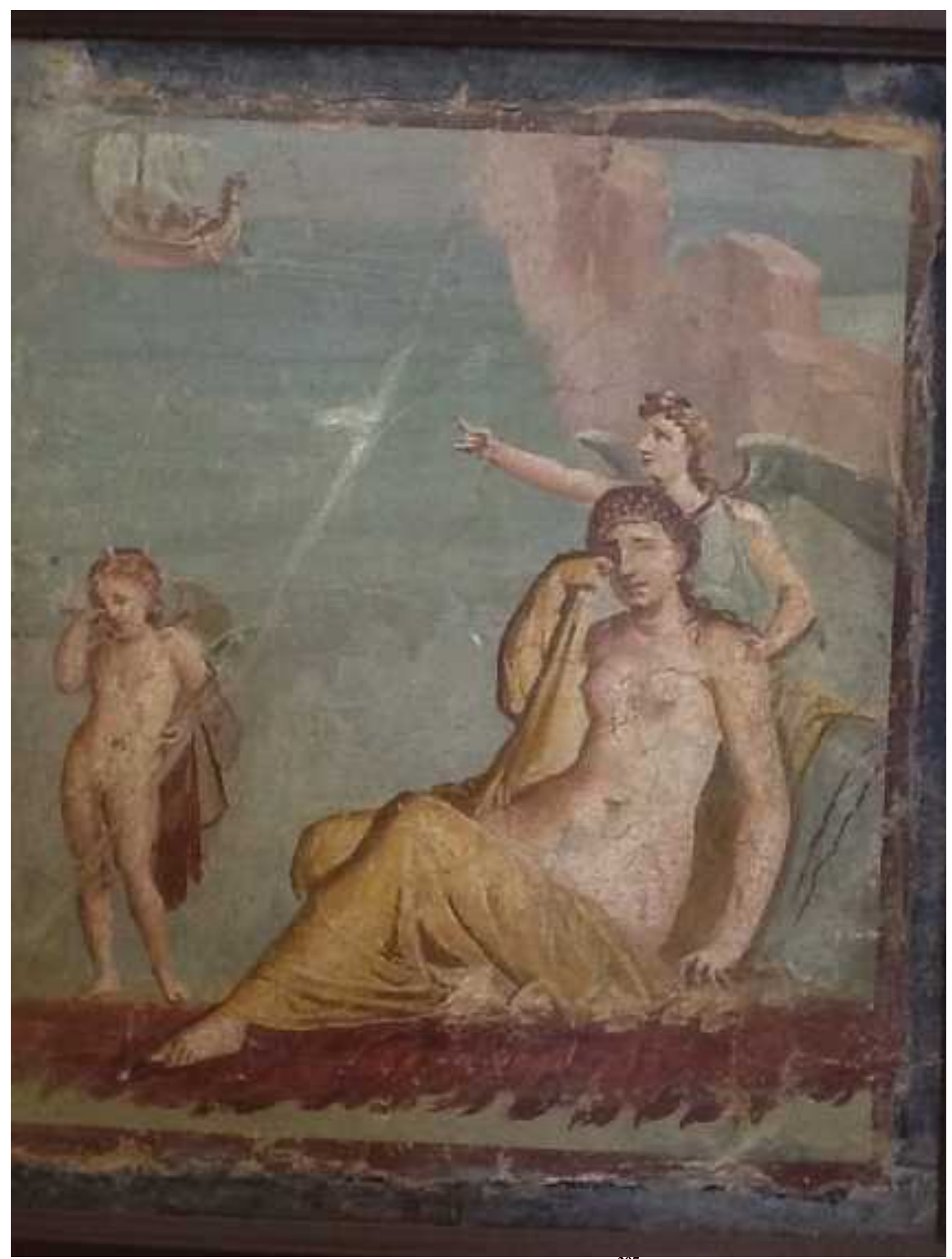

Figura 19. Ariadne abandonada ${ }^{29}$

Nesta cena, a atitude corporal de Cupido sugere que ele compadece-se de Ariadne. Na pintura do abandono de Dido ele não aparece, e se aparecesse,

\footnotetext{
${ }^{297}$ Museo Archeologico Nazionale di Napoli, Nápoles, Itália. Arianna Abbandonata. Inv. 9051. Pompei, Casa di Meleagro. VI 9, 2.13. Peristilo 916), parete ovest (31 gennaio 1830). Alt. Cm 47; largh. cm 42.
} 
provavelmente estaria rindo, se o pintor levasse em consideração sua relação com a rainha apresentada na Eneida. Ariadne pode ser comparada a Dido somente até o momento do abandono, porque o destino de cada uma é diverso: esta última caminhará para o suicídio, enquanto a primeira será resgatada por Baco.

Dido apresenta todos os sintomas da paixão, enquanto Eneias, em determinados momentos, pode apresentar certa vulnerabilidade, porém o caráter heroico da personagem se sobrepõe a esses elementos. O amor de Eneias é suplantado por uma causa maior: ele é o fundador de cidades e executor piedoso dos desígnios divinos. $\mathrm{O}$ amor que se interpõe no seu caminho chega a retardar sua viagem, pois ele se demora entre os carinhos da Fenícia por certo tempo, mas não o impede de seguir rumo ao seu destino final, que é a fundação de um novo lar para os troianos na Itália. Por outro lado, a rainha, ferida de paixão, tal como Medeia, lança maldições e nutre ódio pelo herói; um ódio a consome, e que acaba por destruí-la, dando por completo o plano de Vênus.

O símile da corça ferida, condensa em uma só imagem alguns dos principais elementos que compõe o êthos e o páthos de Dido: infeliz e ferida de amor (saucia cura), ela vaga, insana, pela cidade, como uma corsa atingida por uma flecha:

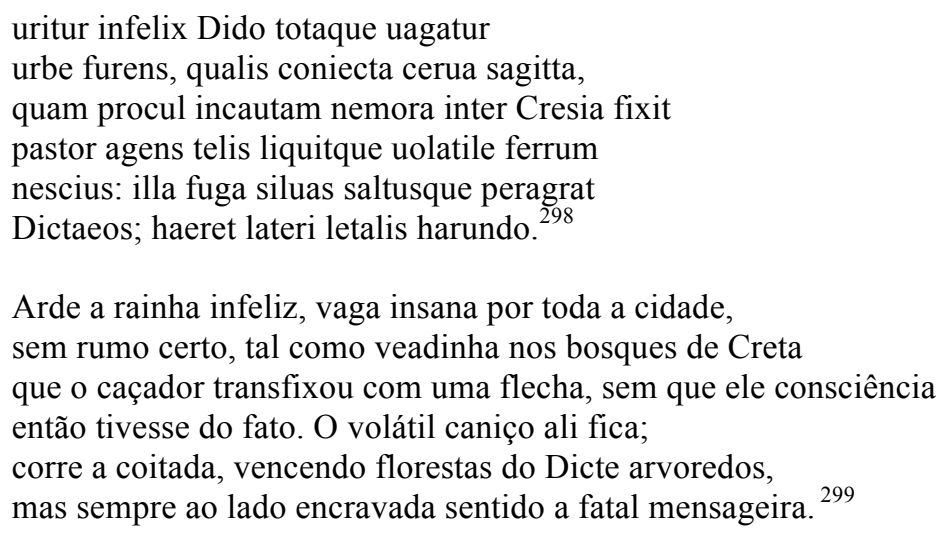

A referência à flecha que atinge e afixa-se no flanco do animal alude às armas de Cupido, o deus arqueiro. A imagem da seta nesse símile é reiterada pelo uso de termos como: sagitta, uolatile ferrum, letalis harundo.

Outro ponto interessante a respeito do símile da corsa é a relação que ele guarda com outro símile, de Dido como Diana ${ }^{300}$. Nota-se que, juntos, eles compõem uma

\footnotetext{
${ }^{298}$ Verg., A. 4.68-73.

299 Tradução de C. A. Nunes.
} 
inversão interessante: Dido, caracterizada como a deusa Diana caçadora, carrega setas (cum pharetra ex Auro) e, no símile da corsa, ela será comparada a uma corsa caçada e ferida de morte por uma flechada. Essa inversão temática ${ }^{301}$, como diz Vasconcellos ${ }^{302}$, salienta "a queda sofrida pela personagem, sua degradação de ser ativo a passivo, de caçadora a caça".

Em suma, Virgílio introduz Amor como personagem da épica no papel de aliado de Vênus em defesa da heroica missão do troiano Eneias. Nessa obra, suas funções de filho e de membro do séquito de Afrodite são evidenciadas, tal como temos observado em outros poemas e em outras artes. Embora esses deuses estejam aparentemente agindo no âmbito do amor pessoal, suas funções na Eneida são épicas: Cupido trabalha sob as ordens da mãe para redirecionar o irmão ${ }^{303}$ de volta ao seu destino heroico, sem o qual Roma jamais existiria.

\footnotetext{
${ }^{300}$ Verg., A. 4.136-139. Justaposto a esse símile, encontra-se símile de Eneias como Apolo (4.142-150). Esse duplo símile alude ao Hino a Diana e Apolo de Calímaco.

${ }^{301}$ Inversão temática por que Dido é comparada a Diana, a deusa caçadora que porta setas, cf. Verg., $A$. 1.500-501: illa pharetam fert umero.

${ }^{302}$ Vasconcellos (2001:104).

${ }^{303}$ Ovídio (Ep. 7.30-32) enfatiza o parentesco entre Eneias e Cupido nas palavras de Dido, ainda iludida, com esperanças ter suas preces atendidas pelos deuses do amor:

non tamen Aenean, quamvis male cogitat, odi, sed queror infidum questaque peius amo. parce, Venus, nurui, durumque amplectere fratrem, frater Amor, castris militet ille tuis!

(Embora Enéias pense mal de mim, não o odeio, apenas queixo-me da sua perfídia, e depois do lamento, o amo ainda mais. Poupa, ó Vênus, esta noiva, protege o teu filho cruel. Ó irmão, Amor, faz com que ele milite em teu exército!)
} 


\section{Delicia, Cupidos da vida real}

Como observamos na Eneida ${ }^{304}$, Cupido despe-se de suas asas e transforma-se no menino Ascânio, marcando presença em um banquete oferecido pela rainha aos troianos $^{305}$. Seu papel nesse contexto familiar e festivo, para Slater ${ }^{306}$, pode ser comparado ao de um delicium, dos quais há vários tipos que iremos considerar daqui em diante, observando especificamente como a imagem desse deus pode fundir-se com a dos humanos e vice-versa, num processo de assimilação. Observamos anteriormente esse processo, citando exemplos em que o deus assume a forma de um humano, como no episódio da Eneida em que ele assimila a figura de Ascânio; e exemplos de humanos assumindo a figura divina, como Propércio, na elegia 2.12 que assimila a puerilis imago de Amor.

O episódio do banquete na Eneida, como dissemos, envolve uma das cenas mais familiares dessa obra épica, em que Cupido-Ascânio encanta a todos com seu brilho divino em meio à celebração. Segundo Slater, os romanos apreciavam a presença de crianças em festas como essas para alegrar o ambiente, e referiam-se a elas utilizando termos como delicium, puer minutus, puer delicatus, deliciae, pupus, pupulus, alumnus, lusus, e outros nomes e codinomes, especialmente os que remetem a filhotes de pássaros. O autor indica que havia delicia de várias idades e funções; evidências epigráficas sugerem que suas idades podiam variar entre dez meses e vinte e seis anos. Enquanto os delicia bebês, como Ascânio, alegravam os banquetes simplesmente com sua presença, havia uma outra classe de meninos adolescentes que eram treinados para animar simpósios com sua loquacidade, desinibição e atrevimento. Segundo Slater, uma das evidências da ligação entre esses jovens com o amor e o simpósio é sugerida por alguns de seus nomes gravados em inscrições: Aphrodisius, Veneria, Apate, Erotion e outros. $\mathrm{O}$ autor ${ }^{307}$ acrescenta que muitos deles eram escravos, porém não necessariamente, e que era comum associá-los às figurações dos Cupidos. Algumas referências textuais elencam algumas de suas principais características: Varrão diz que pueri minuti eram vendidos em mercados de Cápua ${ }^{308}$; Estácio ${ }^{309}$ menciona delicia

\footnotetext{
${ }^{304}$ Verg., A. 1.683-ss..

${ }^{305}$ Verg., A. 1.630-775.

${ }^{306}$ Slater (1974:133-135).

${ }^{307}$ Slater (1974:133-4).

${ }^{308}$ Varr., Men. 3.1.

${ }^{309}$ Estac., S. 5.5.66.
} 
egípcios, notáveis por sua loquacidade; segundo Quintiliano ${ }^{310}$, a linguagem desses jovens nem sempre era correta; e Sêneca ${ }^{311}$ desaprova a prática de treiná-los para serem desinibidos e astuciosos com as palavras. Para Slater, nessas habilidades, talvez residisse o seu valor social, pois, além de sua aura de inocência e da divertida linguagem duvidosa que animava os simpósios, eles eram os únicos a quem era permitido ousar ser impudentes. Embora boa parte dos delicia mencionados fossem do sexo masculino, havia mulheres deliciae também, como a Ipsitila de Catulo: Amabo, mea dulcis Ipsitilla, meae deliciae, mei lepores ${ }^{312}$. (Por favor, minha doce Ipsistila, minha delícia, meu encanto).

A comparação desses jovens com os Cupidos das artes também é constante: Plutarco $^{313}$ diz que Cleópatra seduziu Marco Antônio em um passeio de barco pelo rio Cidno, vestida como Vênus e acompanhada de meninos com os atributos dos Amores posicionados ao seu lado, abanando-a com leques; Plutarco ressalta a semelhança tanto dela como dos pueri com as caracterizações encontradas nas pinturas. Nas Metamorfoses, Apuleio ${ }^{314}$ descreve o momento em que uma jovem vestida de Vênus entra em cena em um anfiteatro, em companhia de doces pueri adornados com todos os detalhes que os tornavam idênticos aos Cupidos:

\footnotetext{
Venus ecce cum magno fauore caueae in ipso meditullio scaenae, circumfuso populo laetissimorum paruulorum, dulce subridens constitit amoene: illos teretes et lacteos puellos diceres tu Cupidines ueros de caelo uel mari commodum inuolasse; nam et pinnulis et sagittulis et habitu cetero formae praeclare congruebant et uelut nuptialis epulas obiturae dominae coruscis praelucebant facibus. ${ }^{315}$

Olha! Vênus, com grande aplauso da plateia, graciosamente posiciona-se ao centro da cena, sorrindo docemente, enquanto um bando de suaves e alvos meninos a circunda, dirias que eram os próprios Cupidos, vindos do alto do céu ou do fundo do mar, com asinhas e flechinhas e todos os detalhes da veste, como se sua senhora estivesse a caminho do altar, aceso diante dela com brilhantes tochas.
}

Suetônio diz que um dos netos de Augusto, uma criança que morreu em tenra idade, foi retratado com os atributos do deus:

habuit in matrimonio Agrippinam, M. Agrippae et Iuliae filiam, et ex ea nouem liberos tulit: quorum duo infantes adhuc rapti, unus iam puerascens insigni festiuitate, cuius effigiem habitu Cupidinis in aede Capitolinae Veneris Liuia dedicauit, Augustus in cubiculo suo positam, quotiensque introiret, exosculabatur. ${ }^{316}$

\footnotetext{
${ }^{310}$ Quint., Inst. Or. 1.2.7.

${ }^{311}$ Sên., Ep. 2.11.3.

312 Cat., Carm. 32.1-2.

${ }^{313}$ Plut., Vit. Antonii 25-26.

${ }^{314}$ Apul., Met. 10.32.1-8.

315 Apul., Met. 10.32.

${ }^{316}$ Suet., Cal. 7.1.
} 
[Germânico] casou-se com Agripina, filha de Marcos Agripa e Júlia, e com ela teve nove filhos, dos quais morreram dois prematuros e um terceiro ainda menino, notável por sua alegria; cuja imagem, caracterizada com os atributos de Cupido, foi dedicada por Lívia no templo de Vênus Capitolina; Augusto colocou uma em seu quarto, que ele costumava beijar toda vez que ali entrava.

Segundo Slater ${ }^{317}$, essa transposição de motivos da arte para a vida e da vida para a arte, talvez fosse mais comum do que imaginamos. A pintura da Vendedora de Cupidos de Herculano, abaixo, segundo ele, pode ser uma reprodução do tema da venda de delicia para ricas matronas romanas. A cena se passa em um ambiente interno. Do lado direito, uma mulher sentada segura pelas asas um Cupido posicionado sobre uma gaiola, dentro da qual outro está aprisionado; e há ainda um terceiro que posiciona-se diante de duas mulheres, às quais é oferecida a "mercadoria". Uma delas, que está sentada, possivelmente é uma matrona, e a outra que está atrás, com a mão pousada sobre o seu ombro direito, provavelmente é uma ama:

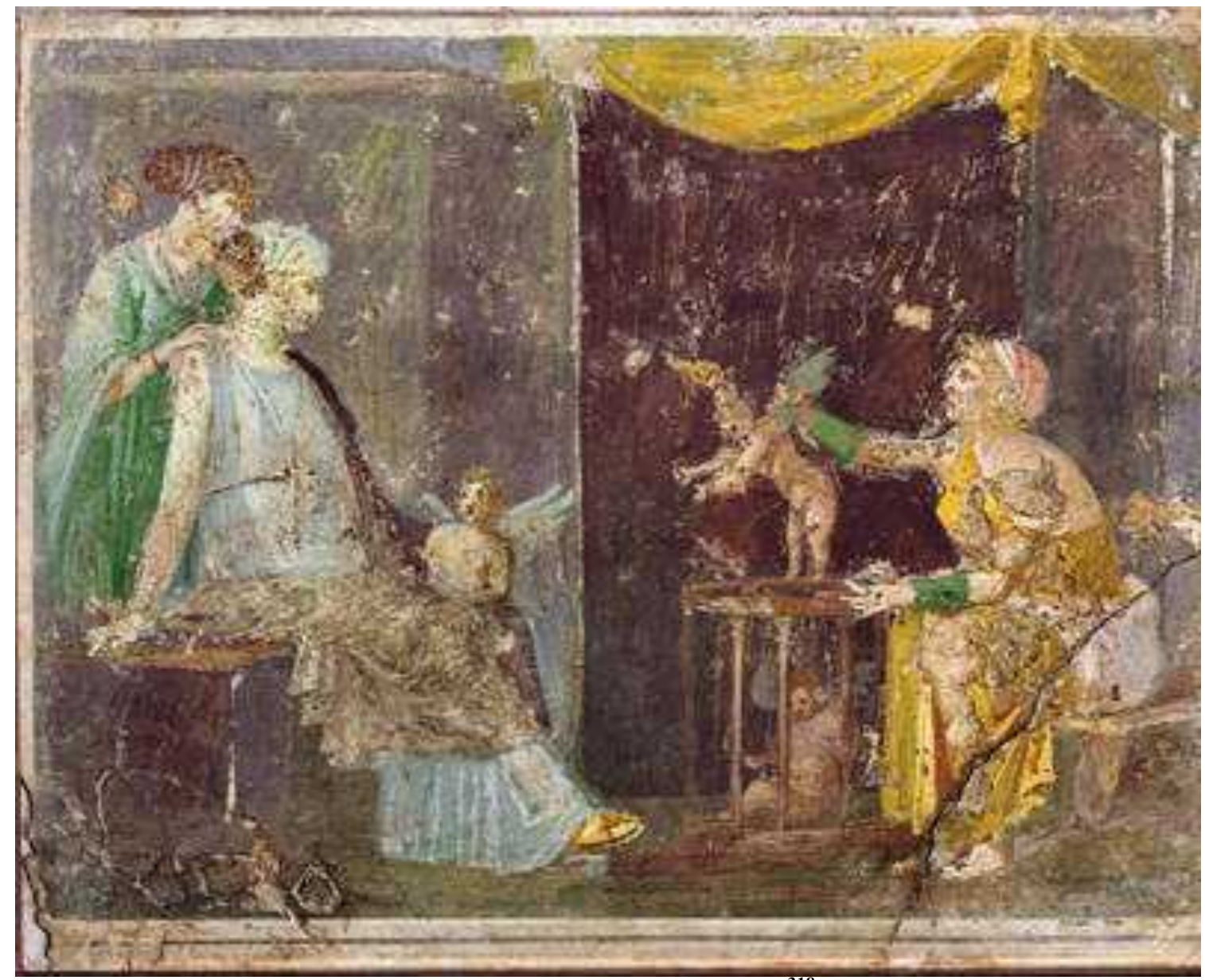

Figura 20. Vendedora de Amorini $^{31}$

\footnotetext{
${ }^{317}$ Slater (1974:135).

${ }^{318}$ Museo Archeologico Nazionale di Napoli, Nápoles, Itália. Venditrice di Amorini. Inv. 9180. Stabia, Villa di Arianna (W25). Alt. $29 \mathrm{~cm}$; largh, cm 35. 1-45 d.C..
} 
O núcleo à esquerda a que pertencem as duas mulheres, matrona e aman, e um dos Cupidos, lembra algumas figurações de Vênus, especialmente a da pintura de Vila Farnesina sobre a qual comentamos anteriormente. Segundo Sampaolo ${ }^{319}$, a pintura acima, descoberta em 1759 em Herculano, durante a expedição de Karl Weber, inicialmente foi interpretada pelos acadêmicos com base no mito de Eros do Simpósio de Platão como: "três Amorini dos quais um repousa no seio de Vênus, acompanhada da Persuasão; o outro deseja escapar da Indigência, ou da Parca; enquanto o terceiro é encarcerado". Somente mais tarde, diz a autora, a cena foi reinterpretada como o tema da vendedora de Amorini.

A venda de Cupidos é mencionada também no epigrama $A$. P. 5.178, já mencionado, de Meleagro, em que o poeta diz querer vender Eros por causa de sua crueldade, mas, ao ser seduzido pela sua loquacidade e olhar agudo, desiste da empresa.

O plural feminino deliciae possuia uma variedade de sentidos em Roma, sendo utilizado não apenas para referir-se aos pueri minuti, mas também a familiares queridos $^{320}$, animais de estimação ${ }^{321}$, deleites, prazeres, ato sexual ${ }^{322}$ e, também, como um eufemismo para relação extra-conjugal ${ }^{323}$. Na poesia, a ambiguidade do termo serve, por exemplo, à ironia dos versos de Catulo, em que a palavra encontra-se no aposto deliciae meae puella, utilizado nos carmina 2 e 3 para qualificar o animal de estimação da amada. O erotismo inerente a esses poemas, permite que observemos o passerdeliciae, não apenas como um animal, mas também como uma referência a um suposto amante ou escravo, que dispusesse dos favores dessa mulher, e que pudesse desfrutar de sua intimidade, recostando-se em seu peito e mordiscando seus dedos, como nota-se nos versos iniciais do carmen 2:

\footnotetext{
Passer, deliciae meae puellae, quicum ludere, quem in sinu tenere, cui primum digitum dare appetenti et acres solet incitare morsus cum desiderio meo nitenti carum nescioquid libet iocari ${ }^{324}$

Pássaro, delícias de minha amiga com quem brincar e ter no colo, a quem no ataque dar a ponta dos dedinhos e acres dentadas incitar costuma quando the apraz ao meu desejo ardente
}

\footnotetext{
${ }^{319}$ Sampaolo (2009:146).

${ }^{320}$ Cic., Att. 1.5.8: Tuliola, deliciae nostrae (pessoa querida).

${ }^{321}$ Cic., Div. 1.76 (animal).

${ }^{322}$ Cat., Carm. 45.24; 74.2.

${ }^{323}$ Cic., Cael. 44.

${ }^{324}$ Cat., Carm. 2.1-6.
} 
quanta laborabas Charybdi,

digne puer meliore flamma. ${ }^{332}$

Quereis que eu também beba parte do

severo Falerno? Que o irmão de Megila Opúncia

diga com que ferida,

com qual seta morre feliz.

Já não há vontade? Não beberei por outros termos.

Seja qual for a Vênus que te dome,

não é necessário corar por causa das paixões abrasadoras,

sempre pecas por casto amor.

$\mathrm{O}$ que quer que guardes contigo, vamos,

confia aos meus fiéis ouvidos. Ah, mísero,

em que grande Caribde te atormentavas,

menino digno de melhor chama!

Quinn $^{333}$ compara esses versos com a passagem da Eneida ${ }^{334}$ sobre a qual discutimos em que Cupido é o causador da ferida da qual padece a rainha cartaginesa. $\mathrm{Na}$ ode 1.27, em meio a um simpósio, Horácio desafia o irmão de Megila a revelar por qual seta foi ferido, um segredo que sugere que o rapaz esteja envolvido com um amor proibido, possivelmente uma relação adúltera com um mulher. Quinn chama atenção para o uso de Venus, no verso 20, como uma metonímia convencional para "amante", referindo-se à mulher, libertina ou matrona, com quem o rapaz está se relacionando. $\mathrm{O}$ oximoro ingenuo semper amore peccas sugere que ele seja um puer delicatus inexperiente no amor como o gracilis puer de Pirra ${ }^{335}$. Ele é atingido no peito por uma flechada que causa uma doce e mortal ferida, uma combinação de efeitos contrastantes que alude ao tópos de Eros doce-amargo, como vimos em exemplos anteriores. Nesse poema, a seta e a chama, que são armas do deus, servem como metáforas para a mulher: é ela quem fere e queima. Tais tópicas eróticas evocam a presença de Vênus e de Cupido personificados nas figuras do puer e de sua amante.

\section{Cupidos no retorno de Vênus}

Nos versos iniciais da ode 4.1, Vênus retorna com seu séquito de Cupidos para requisitar a volta do poeta ao campo de batalha. Horácio, porém, assumindo um êthos de homem maduro, suplica à deusa para que o poupe, argumentando estar endurecido pelo tempo e inadequado para tais incumbências:

Intermissa, Venus, diu

\footnotetext{
${ }^{332}$ Hor., Carm. 1.27.9-20.

${ }^{333}$ Quinn (1980:172).

${ }^{334}$ Verg., A. 4.1.2.

${ }^{335}$ Hor., Carm 1.5.
} 
rursus bella moves? parce precor, precor.

non sum qualis eram bonae

sub regno Cinarae. desine, dulcium

mater saeva Cupidinum,

circa lustra decem flectere mollibus

iam durum imperiis; abi,

quo blandae iuvenum te revocant preces. ${ }^{336}$

Depois de longa trégua, Vênus,

de novo promoves guerras? Poupe-me! Eu te imploro! Eu te imploro!

Não sou mais tal como era

sob o reino da boa Cínara. Mãe

cruel dos doces Cupidos,

cessa de mover alguém próximo aos cinquenta anos,

já duro, para os teus tenros impérios;

parte para onde as brandas preces dos jovens te convidam a retornar.

Tentando desviar-se do fado que a deusa quer imputar-lhe, ele procura apaziguála, apontando para outro alvo, mais adequado: Paulo Máximo, um próspero cidadão romano, jovem de muitas artes, que oferece simpósios com música, dança, perfumes e vinho ${ }^{337}$; alguém capaz de lutar dignamente as batalhas do amor e também prestar homenagens à altura da deusa, colocando sua estátua em um lugar privilegiado de sua propriedade:

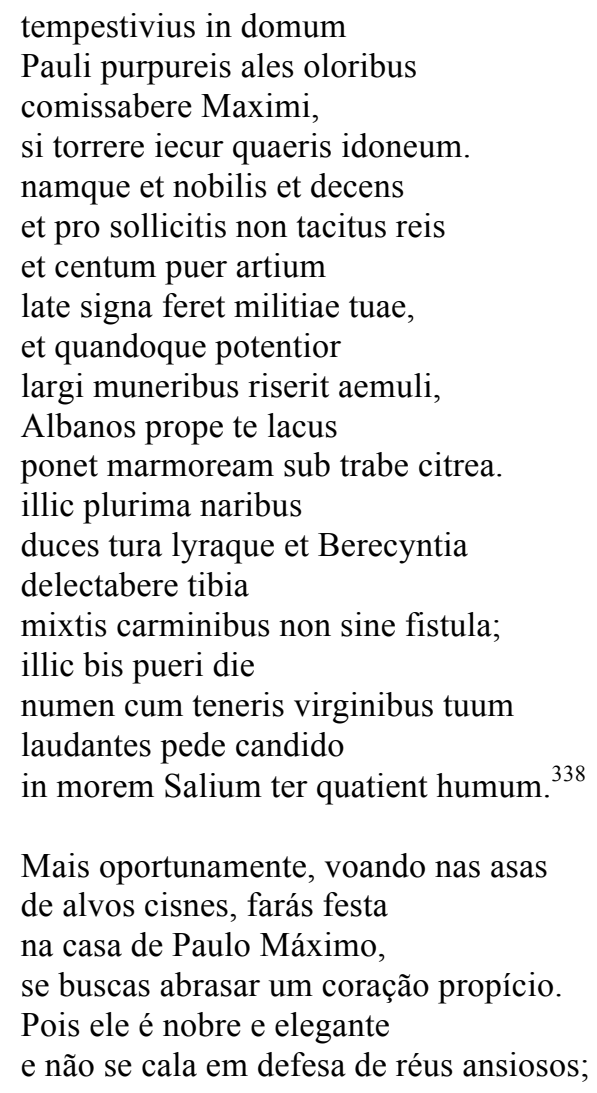

\footnotetext{
${ }^{336}$ Hor., Carm. 4.1.1-8.

${ }^{337}$ Para exemplo de Amor como deus do simpósio cf. Prop., 2.30b.

${ }^{338}$ Hor., Carm. 4.1.9-28.
} 
jovem de muitas artes,

ele conduzirá por largo espaço as insígnias de tua milícia,

e, quando ele tiver rido ao superar os dons do pródigo rival,

colocará, sob teto de limoeiro,

tua estátua de mármore junto ao lago Albano.

Ali inalarás muito incenso, e serás deleitada

pelas canções mistas à lira e

à Berecíntia tíbia, sem faltar a flauta de Pã.

Ali, duas vezes por dia, moços

com tenras virgens, louvando o teu nume,

baterão com cândido pé no chão

três vezes à maneira dos Sálios.

\title{
Horácio recusa o amor e o simpósio, temas líricos por excelência:
}

me nec femina nec puer

iam nec spes animi credula mutui

nec certare iuvat mero

nec vincire novis tempora floribus. ${ }^{339}$

Já não me agradam mais nem mulher, nem moço, nem esperança crédula de paixão correspondida, nem disputar com vinho,

nem coroar-me com flores frescas.

No entanto, surpreendentemente, nos oito versos finais, contrariando as expectativas, ele assume uma paixão secreta pelo jovem Ligurino:

\author{
sed cur heu, Ligurine, cur \\ manat rara meas lacrima per genas? \\ cur facunda parum decoro \\ inter verba cadit lingua silentio? \\ nocturnis ego somniis \\ iam captum teneo, iam volucrem sequor \\ te per gramina Martii \\ campi, te per aquas, dure, volubilis. ${ }^{340}$ \\ Mas, por que, ai!, Ligurino, por que \\ escorre rara lágrima pelas minhas faces? \\ Por que minha língua eloquente, \\ em meio às palavras, cai em indecoroso silêncio? \\ Em sonhos noturnos, \\ ora eu te possuo cativo, \\ ora te persigo enquanto voas, cruel, sobre a relva \\ do Campo de Marte, \\ ou através de águas volúveis.
}

Discutimos anteriormente como a caracterização dos pueri delicati pode ser associada à figuração dos Cupidos. Até que ponto, portanto, podemos dizer que Paulo

\footnotetext{
${ }^{339}$ Hor., Carm. 4.1.29-32.

${ }^{340}$ Hor., Carm. 4.1.33-40.
} 
Máximo e Ligurino, na ode 4.1, apresentam características análogas às do deus? Para Thomas $^{341}$, Paulo Máximo, chamado de puer apesar dos $30 \operatorname{anos}^{342}$, com suas mil artes e seu potencial para a guerra, nesse poema, compara-se a Amor, o eterno puer $^{343}$, também hábil nas $\operatorname{artes}^{344}$ e expoente da militia amoris ${ }^{345}$. A habilidade na guerra e a eterna juventude remtem também à caracterização de Eros nas palavras de Agatão no Simpósio ${ }^{346}$.

Ligurino, por sua vez, é um jovem alado, volúvel e tão duro quanto Amor ${ }^{347}$; ele é indiferente ao lamento do poeta, que o persegue e o captura, ainda que apenas em sonhos. Nesse sentido, Ligurino assume um papel semelhante ao de Ganimedes, o jovem príncipe troiano raptado por Zeus, que não resiste à sua beleza ${ }^{348}$ e o leva consigo para o Olimpo, onde ele passa a servir o néctar aos deuses. Na pintura abaixo, observase a cena do momento do rapto, em que Júpiter, em forma de águia, é guiado pelas mãos de Cupido até o seu alvo ${ }^{349}$ :

\footnotetext{
${ }^{341}$ Thomas (2011:93).

${ }^{342}$ Thomas (2011:91): Paulo Fábio Máximo nasceu por volta de 46 a.C.

${ }^{343}$ Prop. 2.12.1 puer amor; 13 puerilis imago.

${ }^{344}$ Cf. Prop. 1.1.17 in me tardus Amor non ullas cogitat artes; Virg., Aen. 1.657-9: At Cytherea nouas artis, noua pectore uersat consilia, ut faciem mutatus et ora Cupido pro dulci Ascanio ueniat; Ov., Pont. 1.4.41: Illum furtiuae iuuere Cupidinis artes.

${ }^{345}$ Prop. 2.8.29-40: inferior multo cum sim vel matre vel armis, mirum, si de me iure triumphat Amor?

${ }^{346}$ Platão, Sym. 196a-196-e.

${ }^{347}$ Prop., 1.3.14: Durus Amor.

${ }^{348}$ Hom., Il. 20.231-265.

${ }^{349}$ Sampaolo (2009:291).
} 


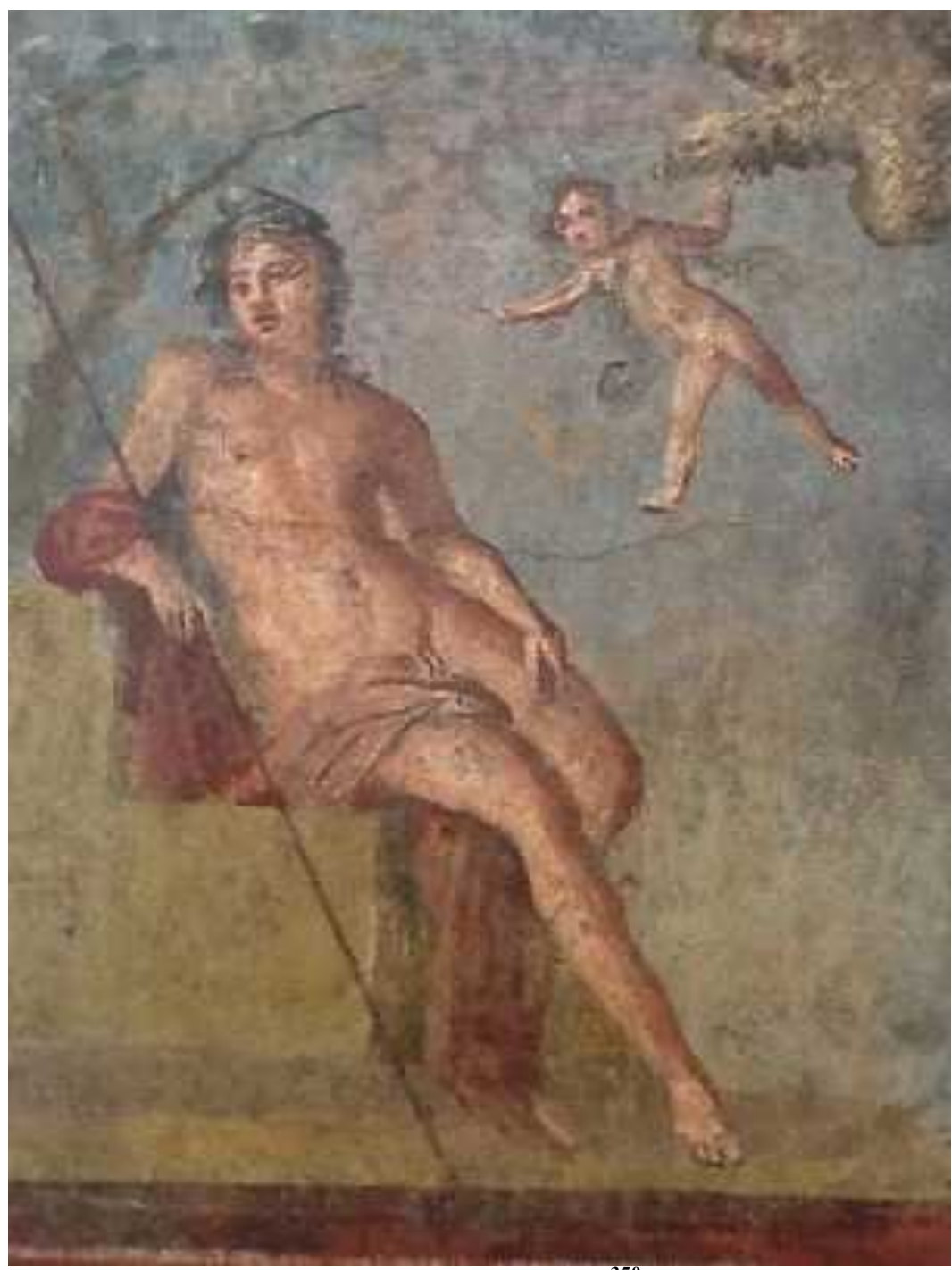

Figura 21. Ganimedes ${ }^{350}$

Essa ação nos lembra a soberania de Amor sobre todos os seres, ele é a força e a potência de Vênus ${ }^{351}$, e seu papel é mover o jogo e pôr em prática os ardis do amor. Na pintura abaixo, envoltos em um arco-íris, encontram-se Zeus e Eros, que aponta para baixo, indicando o mundo dos mortais. A presença águia, à esquerda, remete ao episódio de Ganimedes:

\footnotetext{
${ }^{350}$ Museo Archeologico Nazionale di Napoli, Nápoles, Itália. Inv. 9547. Ganimede. Pompei, Casa di Meleagro, VI 9, 2.13, cubicolo (12), parete est. Alt. cm 37; largh. cm 34. 69-79 d.C..

${ }^{351}$ Verg., A. 1.664: nate, meae uires, mea magna potentia.
} 


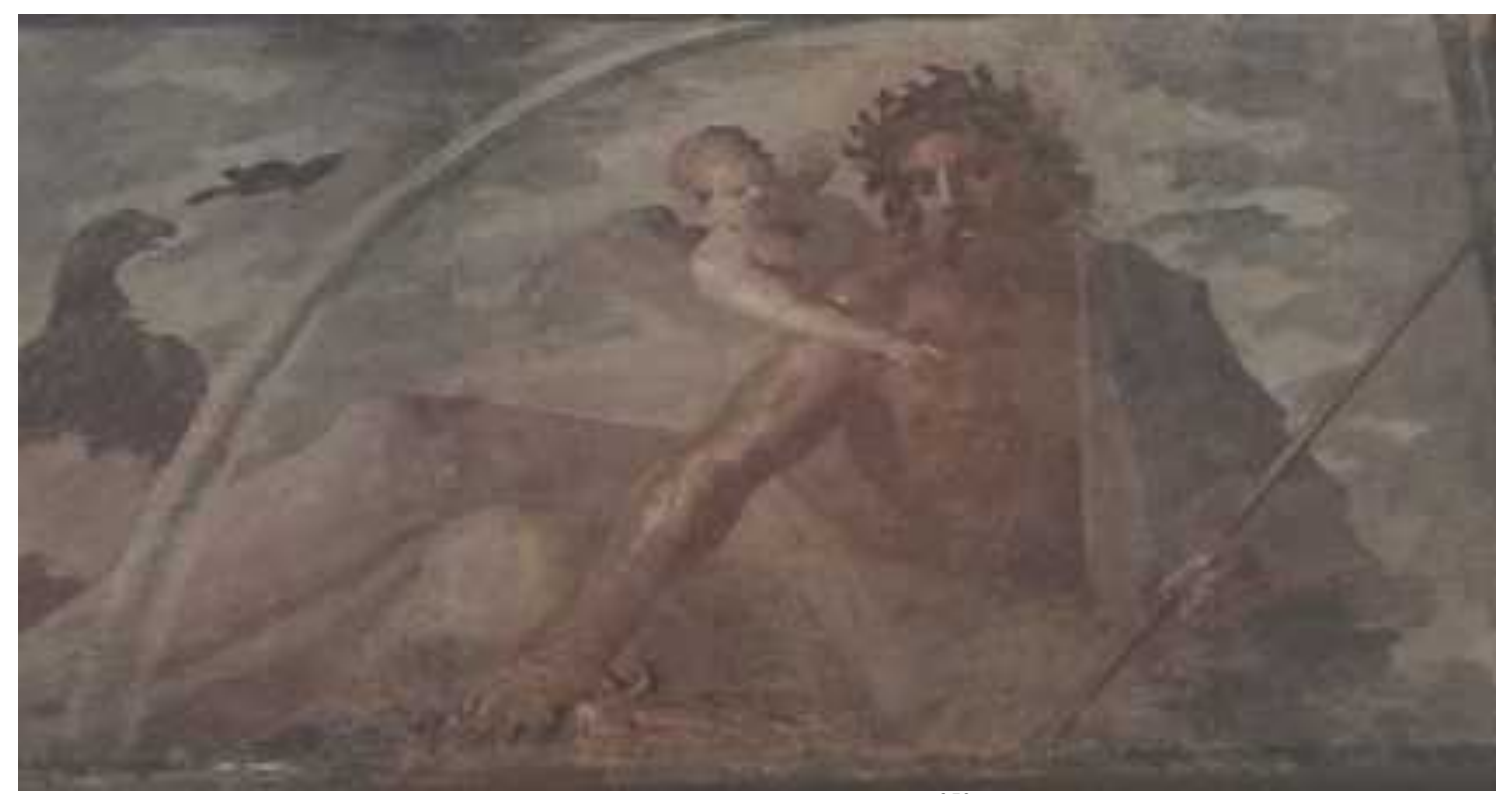

Figura 22. Eros e Amorino ${ }^{352}$

Zeus não resiste aos comandos de Eros e sequestra Ganimedes. Horácio, do mesmo modo, em sonhos, lança-se como uma ave de rapina sobre o jovem Ligurino. Com a mente consumida por ardente desejo, ele lamenta-se em vão por um amor não correspondido.

Thomas $^{353}$ observa que os oito versos finais da ode 4.1 possuem um sabor do epodo 11, além de elementos do iambo grego, da comédia e de epigramas eróticos helenísticos ${ }^{354}$. Segundo Calame ${ }^{355}$, em epigramas helenísticos, normalmente não há como separar a figura de Eros arqueiro do jovem que é objeto de desejo. Misco ${ }^{356}$, nos poemas de Meleagro, com seus olhos, lança setas que atingem o poeta no peito. Neste outro epigrama, abaixo, do mesmo autor, Eros traz sonhos que inflamam o poeta de desejo por um jovem alado, a quem ele persegue em sonhos, embora tente recusar enquanto acordado, tal qual Horácio a Ligurino:

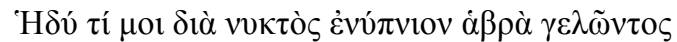

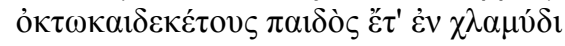

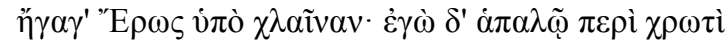

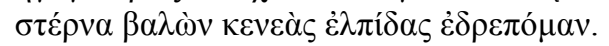

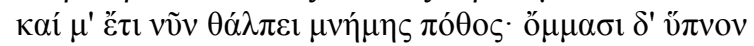

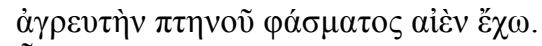

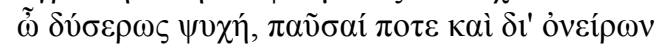

\footnotetext{
${ }^{352}$ Museo Archeologico Nazionale di Napoli, Nápoles, Itália. Inv. 9553. Zeus e Amorino. Ercolano. Alt. cm. 108; largh. Cm 105; 1-37 d.C.

353 Thomas (2011: 99).

${ }^{354}$ Meleagro, A.P. 12.75. 12.101.

${ }^{355}$ Calame (1999:58).

${ }^{356}$ Meleagro, A.P. 12.101.
} 


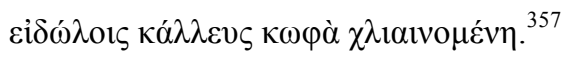

Esta noite, sob o manto, um doce sonho

Eros deu-me: um jovem de dezoito anos que ria graciosamente ainda em sua clâmide. E pressionando

o meu peito contra seu tenro corpo colhi esperanças vazias.

E ainda agora a memória do desejo me aquece. Tenho sempre nos olhos o sono que caça a alada visão.

Alma, amante infeliz, pára de excitar-te em vão nos sonhos por meio de fantasmas de beleza. ${ }^{358}$

Enfim, na ode 4.1, os pueri Paulo Máximo e Ligurino possuem características que nos levam a imaginá-los como desdobramentos dos doces Cupidos de Vênus. Sua presença, na forma de dois belos rapazes, atenua o endurecido poeta, movendo-o, de algum modo, de volta às batalhas de Vênus.

\section{Pueri Turba Minuta}

Na elegia 2.29a de Propércio, nos deparamos com outro exemplo de assimilação em que o deus, ou melhor, um grupo deles se encarrega de tarefas que os aproximam dos mortais. Uma turba minuta de irmãos nus, alados e armados, cerca e captura o poeta nas ruas da cidade à noite, levando-o de volta à casa de uma mulher:

Hesterna, mea lux, cum potus nocte uagarer, nec me seruorum duceret ulla manus, obuia nescio quot pueri mihi turba minuta uenerat (hos uetuit me numerare timor); quorum alii faculas, alii retinere sagittas, pars etiam uisa est uincla parare mihi. sed nudi fuerant. quorum lasciuior unus, 'Arripite hunc,' inquit, 'iam bene nostis eum hic erat, hunc mulier nobis irata locauit.' dixit, et in collo iam mihi nodus erat.

hic alter iubet in medium propellere, at alter, 'Intereat, qui nos non putat esse deos! haec te non meritum totas exspectat in horas: at tu nescio quas quaeris, inepte, fores. quae cum Sidoniae nocturna ligamina mitrae soluerit atque oculos mouerit illa grauis, afflabunt tibi non Arabum de gramine odores, sed quos ipse suis fecit Amor manibus. parcite iam, fratres, iam certos spondet amores; et iam ad mandatam uenimus ecce domum.' atque ita me iniecto dixerunt rursus amictu: 'I nunc et noctes disce manere domi. ${ }^{359}$

\footnotetext{
${ }^{357}$ Meleagro, A.P. 12.125.

${ }^{358}$ Tradução de F. V. Amaral.

${ }^{359}$ Prop. 2.29a.
} 
À noite passada, luz minha, quando ébrio vagava

E coorte alguma de servos acompanhava

Turma diminuta - não sei de quantos meninos

Veio ao meu encontro - o temor impede de numerá-los -

Uns deles, pequenas tochas; outros levavam dardos

Uma parte pareceu preparar-me armadilha.

E estavam nus. Um deles era mais lascivo

E disse: "Agarrai-o, já bem o conheceis."

"Era ele, é ele que a irada mulher nos entregou"

Disse e no meu pescoço um nó já havia

Outro manda que me empurrem para o meio,

Mas outro:"Morra quem não nos crê deuses!"

Ela te espera, imerecedor, por horas:

$\mathrm{E}$ tu, inepto, não sei quais outras procuras.

Quando ela tiver soltado os laços noturnos da mitra sidônia

E tiver entreaberto olhos pensos de sono

Odores te chegaram não de ervas arábicas,

Mas os que os o próprio Amor fez com suas mãos.

"Poupai já, irmãos, já promete tudo de amor."

"Eis já chegamos à casa mandada."

E restituído meu manto, disseram:

"Vai agora e aprende a ficar em casa às noites" $" 360$.

Propércio endereça o poema a alguém chamado pelo apelido carinhoso de mea $l u x^{361}$, e relata a cena, começando por dizer que estava a vagar à noite embriagado (cum potus nocte), quando subitamente tem o seu caminho interceptado por um bando de pueri. Propércio introduz essas personificações, identificando-as por seus caracteres físicos e anímicos e uma série de ações. Ele podem ser vistos como uma alegoria para os diversos desejos e paixões que aprisionam. Segundo Quintiliano ${ }^{362}$, a alegoria se constitui por uma sucessão de metáforas: "alegoria facit continua metaphora." (a metáfora continuada compõe uma alegoria); sobre a qual Lausberg ${ }^{363}$ explica que:

\begin{abstract}
A alegoria é para o pensamento o que a metáfora é para a palavra: a alegoria guarda, pois, com o pensamento uma relação de comparação. A relação da alegoria com a metáfora é quantitativa; a alegoria é uma frase inteira (às vezes mais).
\end{abstract}

Propércio descreve a cena, adotando um procedimento que atribui ao seu discurso uma qualidade que Quintiliano denominou de euidentia, a vividez, que pode ser obtida, entre outros meios, pelo detalhadamento de pessoa ou objeto ${ }^{364}$. Tal qualidade contribui para o que o discurso fustigue os afetos e estimule os ouvintes a produzir uma imagem mental denominada phantasia:

\footnotetext{
${ }^{360}$ Tradução de P. Martins.

${ }^{361}$ Provavelmente Cíntia, tomando-se por base referências encontradas na elegia seguinte, Prop., 2.29.b.

${ }^{362}$ Quint., Inst. Or. 9.2.46.

${ }^{363}$ Lausberg (2003:283-4).

${ }^{364}$ Cf. Lausberg (2003:228).
} 
Quas $\varphi \alpha v \tau \alpha \sigma i ́ \alpha \varsigma$ Graeci uocant (nos sane uisiones appellemus), per quas imagines rerum absentium ita repraesentantur animo ut eas cernere oculis ac praesentes habere uideamur, has quisquis bene ceperit is erit in adfectibus potentissimus. ${ }^{365}$

Aquilo que os gregos chamam de phantasíai, nós certamente chamamos de visões, pelas quais as imagens das coisas ausentes são de tal modo representadas na alma, que parecemos vê-las com os olhos e tê-las presentes. Quem quer que as conceba bem, será o mais poderoso nos afetos." 366

Propércio especifica detalhes sobre os personagens: os pueri minuti são caracterizados como um bando de jovens irmãos, nus e armados com tochas, flechas e grilhões. Eles estão a serviço de uma mulher e capturam Propércio, que está bêbado nas ruas da cidade, e o levam de volta para a casa de sua domina, que é bela com suas vestes finas e perfumes feitos por Amor. Tais caracteres e relações remetem à figuração de Vênus e dos Cupidos. De acordo com Slater ${ }^{367}$, é razoável imaginar esses jovens como escravos a serviço de uma mulher de quem o poeta é um visitante frequente, a ponto de sua presença ser exigida durante a noite. $\mathrm{O}$ autor ressalta que, do mesmo modo que as matronas possuíam delicia à sua disposição, provavelmente as mulheres do demi-monde também quisessem imitar esse costume; assim, não seria difícil imaginar que houvessem escravos a serviço de mulheres como Cíntia ou Délia ${ }^{368}$.

Após a descrição detalhada dos Pueri, a partir do verso 8, Propércio passa a atribuir-lhes falas. O processo de caracterizar pessoas, reais ou imaginárias, em diálogos ou monólogos é chamado sermocinatio. Lausberg ${ }^{369}$ ensina que:

\begin{abstract}
a sermocinatio guarda certa relação com a evidência, sem ser uma parte necessária da figura da evidência. A sermocinatio consiste em fingir, para caracterizar pessoas naturais (históricas ou inventadas), ditos, diálogos, monólogos ou reflexões não verbalizadas das pessoas correspondentes... A sermocinatio é inventada pela força da fantasia do autor. A forma que adota normalmente na linguagem é o discurso direto.
\end{abstract}

As falas dos Pueri são imperativas: um deles, o mais lascivo e que comanda as ações dos demais, ordena que amarrem o poeta: 'Arripite hunc,' inquit, 'iam bene nostis eum hic erat, hunc mulier nobis irata locauit.' Outro proclama: "Intereat, qui nos non putat esse deos!' Esta fala é interessante, pois parece sugerir que há dúvida quanto ao caráter divino dos meninos.

\footnotetext{
${ }^{365}$ Quint., Inst. Or. 6.2.29-30.

366 Tradução de M. Rodolpho (2010:89).

${ }^{367}$ Slater (1974:136).

${ }^{368}$ Tib., 1.5.26. consuescet amantis garrulus in dominae ludere verna sinu.

${ }^{369}$ Lausberg (2003:235-236).
} 
Na elegia de Propércio, os Pueri impõem ao poeta determinado comportamento, advertindo para que ele aprenda a permanecer em casa e não saia mais em busca de outras mulheres. Segundo Conte ${ }^{370}$, as ligações amorosas nos poemas de Propércio, embora envolvam relações com cortesãs ou mulheres livres, tendem a ser figuradas como relações conjugais "ligadas pela fides, asseguradas pela pudicitia, e com ressalvas ao luxo e sofisticação urbana". ${ }^{371}$

Cairns sugere que a elegia 2.29a de Propércio possui elementos de fantasia, mas por outro lado evidencia aspectos da realidade, considerando-se as ações dos Cupidos. Para ele, o cenário urbano reforça a ideia de que os pueri estivessem exercendo um papel análogo ao da vida real, o de fugitiuarii, pessoas que saem à caça de fugitivos. Nesse caso, o próprio poeta estaria fazendo o papel de fugitiuus, que, uma vez capturado, deve submeter-se novamente ao seruitium amoris à sua domina.

Um dos Pueri elabora um retrato epidítico da puella, evidenciando seu poder de sedução, cujo apelo reside nas vestes, no olhar e nos perfumes fabricados por Amor. Como podemos notar, a fabricação de perfumes é uma das muitas habilidades do deus evidenciadas na poesia. Catulo também atribui essa arte aos Cupidos e Vênus nesses versos:

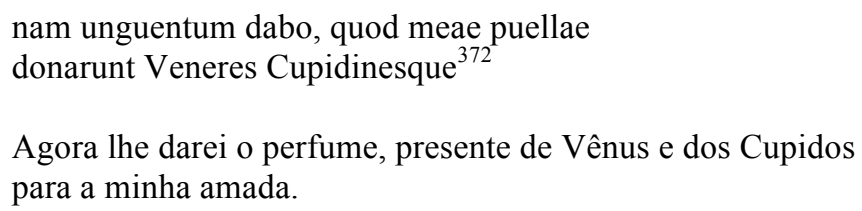

Como sabemos, eram comuns ao imaginário romano as representações de bandos de Amorini praticando os mais diversos ofícios. A forma pluralizada do deus dá maior destaque à ação que une o grupo do que ao caráter individual de cada personagem, como podemos observar não só na poesia, mas também em pinturas parietais de Pompeia e gemas em que figuram Amorini exercendo ofícios e jogos, entre outras atividades humanas das mais diversas naturezas.

Na pintura abaixo, um grupo de Cupidos produz perfumes: dois deles misturam o líquido em um recipiente, atrás dos quais há armários com frascos. À direita, outro Cupido segura um alabastro, enquanto Psiquê, sentada, testa o produto, inalando o aroma que emana de sua pele:

\footnotetext{
${ }^{370}$ Conte (1999: 323).

${ }^{371}$ Cairns (1971:455).

${ }^{372}$ Cat., Carm. 13.11-12.
} 


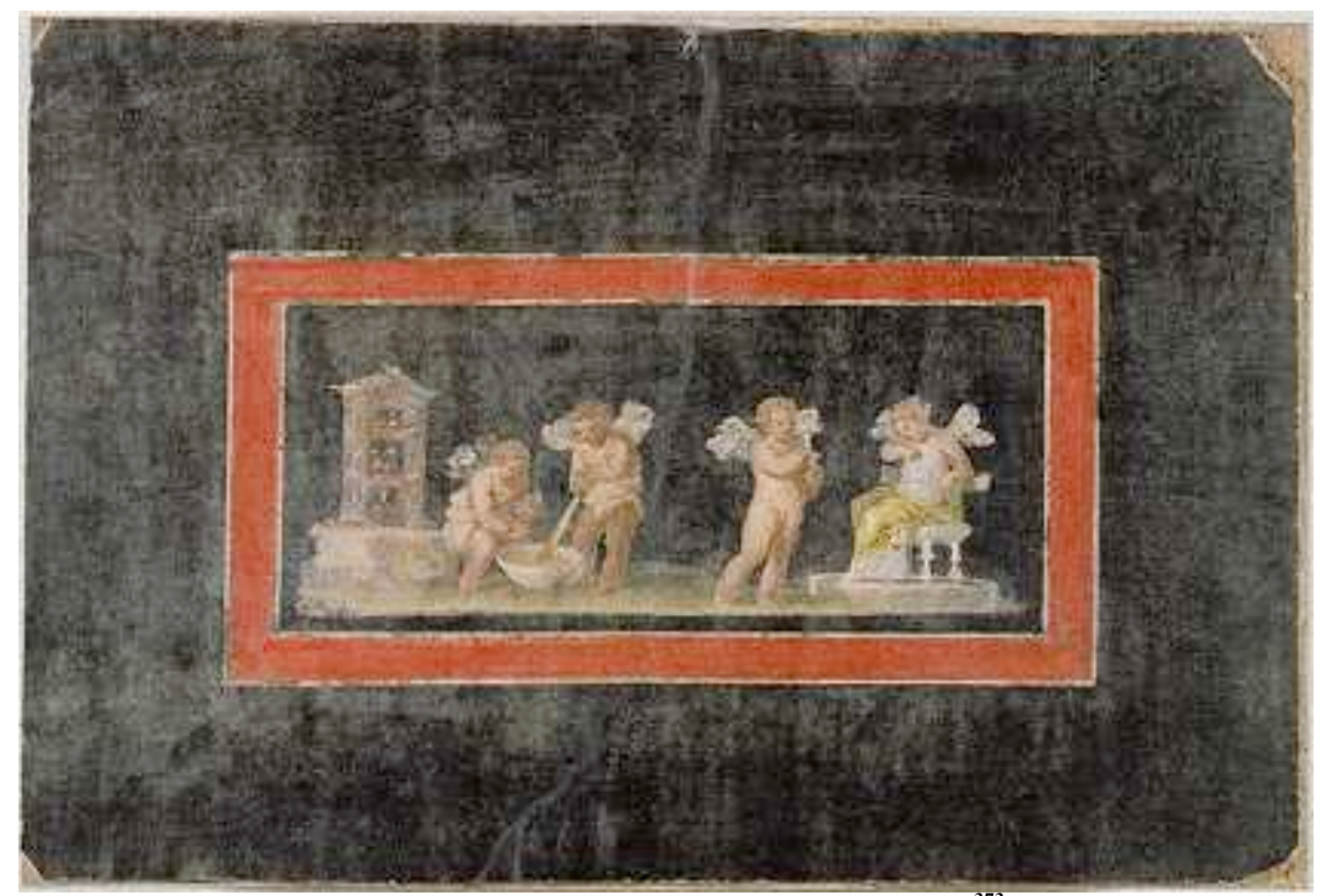

Figura 23. Cupidos e Psiquê fabricando perfumes ${ }^{373}$

Em pinturas de Pompeia, Cupidos aparecem com frequência desempenhando esses ofícios ao lado de Psiquês, porém nos poemas, ele as realiza ao lado de Vênus, como vimos nos poemas acima. Na poesia latina, Psiquê aparece mais tardiamente, nas Metamorfoses de Apuleio, como esposa do deus, uma mortal caracterizada por tamanha beleza a ponto de causar inveja em Vênus.

Propércio, na elegia 2.29, evidencia a intimidade dos pequenos Erotes com as armas, como tochas, correntes e flechas. No camafeu abaixo, eles aparecem forjandoas $^{374}$ :

\footnotetext{
${ }^{373}$ The Getty Museum. Wall Fragment with Cupids and Psyche Making Perfume. 72.AG.81. Roman, A.D. 50 - 75. Plaster and pigment . 14 15/16 x $221 / 16$ in..

${ }^{374}$ Hor., Carm., 2.8.13-16: ridet hoc, inquam, Venus ipsa, riden simplices Nymphae ferus et Cupido semper ardentis acuens sagitas cote cruenta.
} 


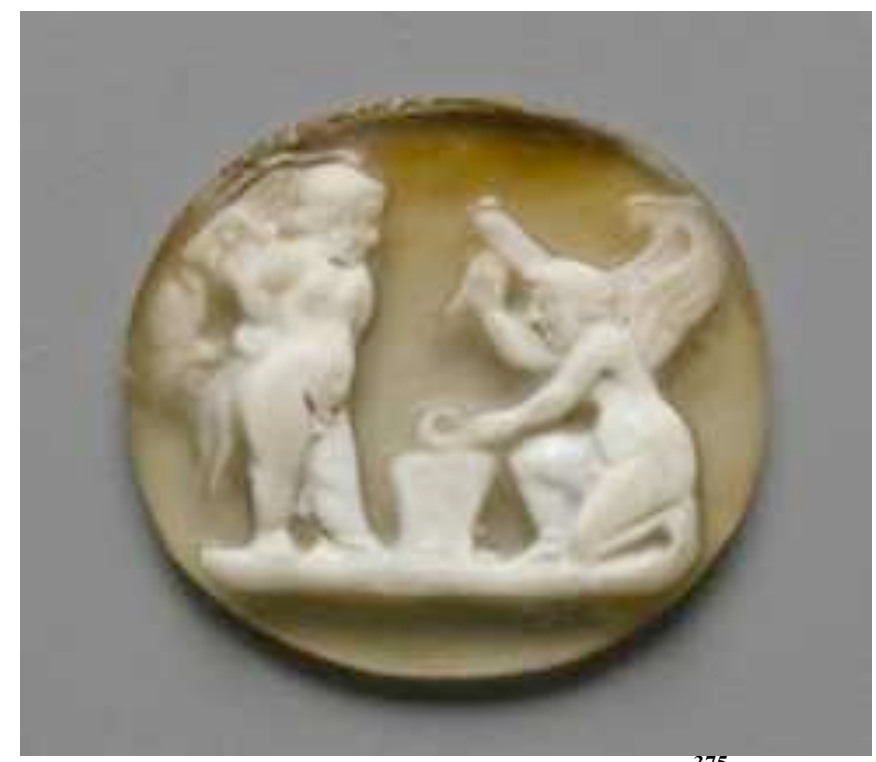

Figura 24. Erotes fabricando armas ${ }^{37}$

Os Amorini são frequentemente figurados em oficinas de metais; esse motivo aparece também em pinturas parietais, como essa, abaixo, que faz parte do friso em fundo negro que estende-se pelas quatro paredes de uma sala na Casa dos Vetti, em Pompeia, e apresenta todos os diversos estágios dessa $\operatorname{arte}^{376}$ :

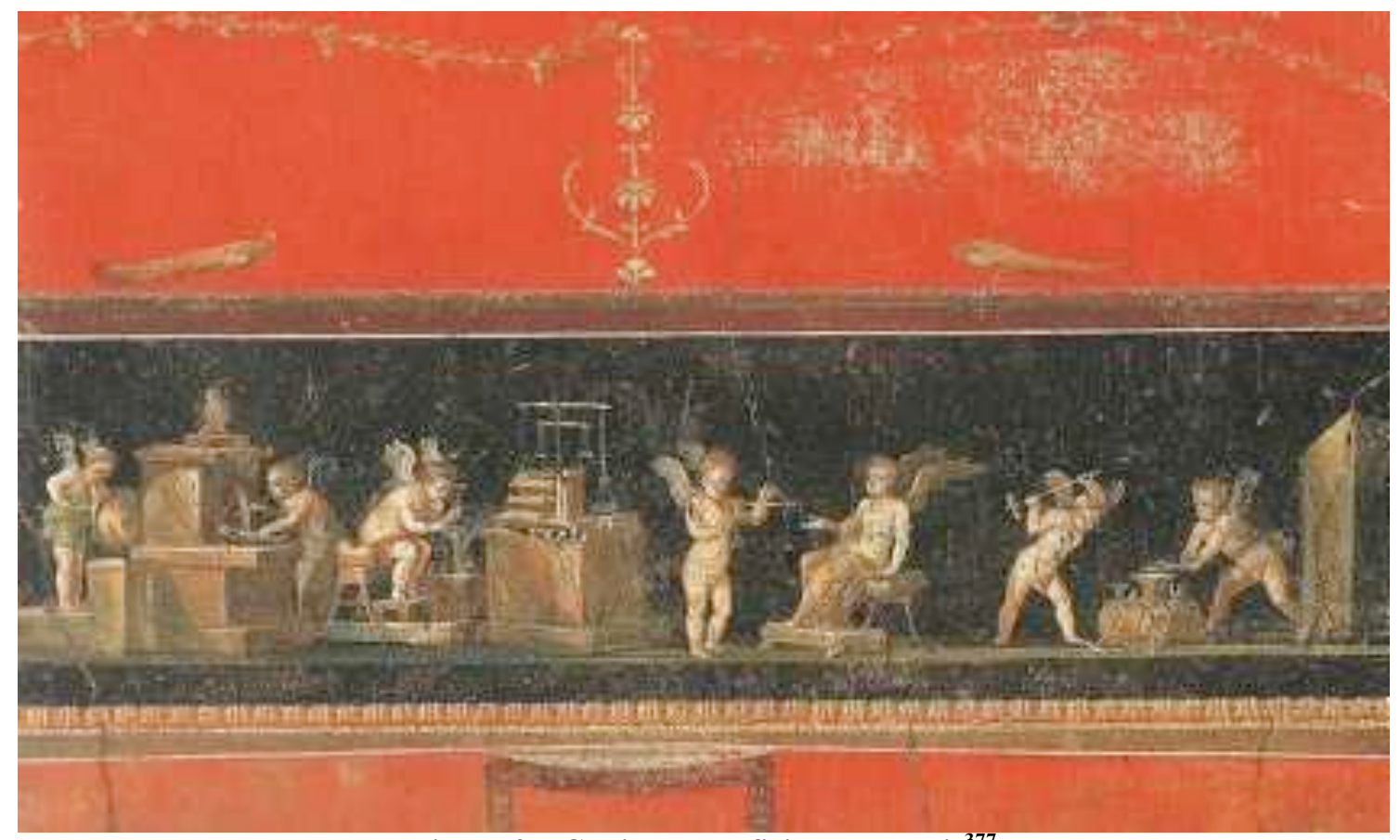

Figura 25. Cupidos em oficina de metais ${ }^{377}$

\footnotetext{
${ }^{375}$ Cameo of two erotes making arms. Roman, Imperial Period, 1st to 3rd century A.D. Length: $1.7 \mathrm{~cm}$ (11/16 in.). Sardonyx, cameo. Classification: Jewelry / Adornment. Object is currently not on view. Two erotes as armourers. Museum of Fine Arts, Boston. Francis Bartlett Donation of 1912, 1927. Accession number: 27.751 .

${ }^{376}$ Ling (2009:78). Sobre essa pintura cf. também Clarke (1991:208-35).

${ }^{377}$ Pompeii, VI 15, I. House of the Vettii. Oecus q. Date: soon after 62 d.C. Cupids engaged in metalworking.
} 
Os Pueri, hábeis em muitas artes, são figurados ao longo desse friso da Casa dos Vettii parodiando atitudes e gestos humanos ao desempenhar, além deste, diversos ofícios, como a fabricação de perfumes, guirlandas, tecelagem, vinicultura; além de atividades lúdicas, como a corrida de bigas; e religiosas, como o thiasos dionisíaco.

Concluímos que em sua forma pluralizada, tal como vimos na elegia de Propércio e nas obras acima, os Pueri podem assumir papéis que os aproximam dos humanos. Na elegia 2.29.a de Propércio, eles aparecem como fugitiuarii, incumbidos da missão de resgatar o fugitivo amante para sua domina, além de produzir perfumes; e, nos frisos da Casa dos Vetti e de diversas outras pinturas pompeianas, como dissemos, há uma variedade quase infindável de exemplos que poderiam ser citados de atividades humananos desempenhadas pelos Cupidos.

\section{Cupido e o princípio da atração}

Embora Cupido figure normalmente como vetor das paixões, como temos visto em vários exemplos, ele não é invulnerável a elas, como objeto da paixão ou apaixonado. Com poder sobre os domínios do ar, ele é uma figura altamente volátil, porém desloca-se com mais facilidade para dentro do que para fora de suas vítimas. Como diz Propércio na elegia 2.12, quando ele atinge o peito parece perder suas asas, pois não voa mais para lugar algum; como força veemente instalada no interior de sua vítima, ele exerce o poder de atração, movendo os passos dos amantes em direção ao objeto desejado. Ele é um condutor da atração sexual, e porta o laço ou uinculum que une ou amarra os amantes. Nesse sentido, suas armas são tanto as correntes (catena) que simbolizam o seruitium amoris, como o laço (uinculum ${ }^{378}$ ), que pode ser usado tanto para subjugar como para unir os amantes em matrimônio, como nessa elegia de Tibulo:

\footnotetext{
Vota cadunt: utinam strepitantibus advolet alis Flavaque coniugio vincula portet Amor,

Vincula, quae maneant semper, dum tarda senectus Inducat rugas inficiatque comas.

Huc venias, Natalis, avis prolemque ministres,

Ludat ut ante tuos turba novella pedes. ${ }^{379}$

Votos acontecem: queira que o Amor voe com asas

Retumbantes e carregue os flavos vínculos da união,
}

\footnotetext{
${ }^{378}$ Vinculum na tópica seruitium amoris, cf. Tib., 2.4.

${ }^{379}$ Tib., 2.2.17-22.
} 
Vínculos que sempre permanecerão, até que a tarda velhice

Tiver trazido as rugas e tiver encanecido os cabelos.

Aqui virás, Natal, ministrarás as aves e a prole

Para que diante dos teus pés a jovem turba brinque. ${ }^{380}$

Segundo Cairns ${ }^{381}$, a elegia 2.2 de Tibulo é um genethliakon, gênero específico de poemas dedicados à celebração de aniversários, neste caso, o de Cornuto, um amigo do poeta, a quem ele faz votos que Amor favoreça com uma união duradoura.

Nas Metamorfoses de Ovídio, Amor figura ao lado de Himeneu carregando as tochas na procissão matrimonial no casamento de Perseu e Andrômeda:

protinus Andromedan et tanti praemia facti indotata rapit; taedas Hymenaeus Amorque praecutiunt; largis satiantur odoribus ignes, sertaque dependent tectis et ubique lyraeque tibiaque et cantus, animi felicia laeti argumenta, sonant; reseratis aurea valvis atria tota patent, pulchroque instructa paratu Cepheni proceres ineunt convivia regis. ${ }^{382}$

No mesmo instante, o herói clama unicamente Andrômeda, sem dote, para si como prêmio por seu grande feito. Amor e Hímen agitam as tochas matrimoniais; o fogo é alimentado com ricos perfumes, guirlandas pendem do teto, e por todo canto ressoam a lira, a flauta e o canto, felizes indícios de ânimo alegre. Abertos os portões, todos os áureos átrios revelam-se com um belo banquete do qual participam os nobres da corte de Cefeu.

Dois Cupidos aparecem em uma pintura que inclui um conjunto de vinte e nove figuras em tamanho real distribuídas ao longo das quatro paredes em fundo vermelho do oecus 5 da Vila dos Mistérios em Pompeia; segundo Ling ${ }^{383}$, uma figuração helenizante, que apresenta um aspecto característico da arte romana: a mistura de figuras míticas, alegóricas e humanas. Os personagens interagem por meio de suas posições corporais e olhares, porém há controvérsia entre os pesquisadores quanto ao significado de suas relações. Ling e Papallardo propõem uma leitura dessa sequência como as diversas fases de um ritual dionisíaco, com a iniciação de uma jovem aos mistérios do matrimônio. $\mathrm{O}$ núcleo central apresenta Dioniso, que desfalece lânguido nos braços de Ariadne ${ }^{384}$, ao redor dos quais encontram-se membros de seu séquito, como Sileno, sátiros e bacantes, e outros personagens míticos, alegóricos e humanos que compõem a cena. As figuras abaixo formam um dos núcleos dessa pintura: uma noiva sentada, veste uma túnica cobrindo parte de seu corpo; seus braços estão adornados com pulseiras e as mãos

\footnotetext{
${ }^{380}$ Tradução de P. Martins

${ }^{381}$ Cairns (2010:113).

382 Ov., Met. 4.757-764.

${ }^{383}$ Ling (2009:102-104).

${ }^{384}$ Papalardo (2009:50) propõe além de Ariadne, alternativamente Vênus, protetora da cidade. A pintura está danificada na parte superior, dificultando a interpretação. Segundo Ling, a intepretação como Ariadne reforça a ideia que trata-se de uma iniciação nos mistérios do casamento.
} 
tocam os cabelos, que estão sendo penteados por uma ama para o casamento $^{385}$. Posicionado em pé sobre um pedestal em que estão essas duas mulheres, Cupido segura um espelho, objeto ligado à figuração de Vênus:

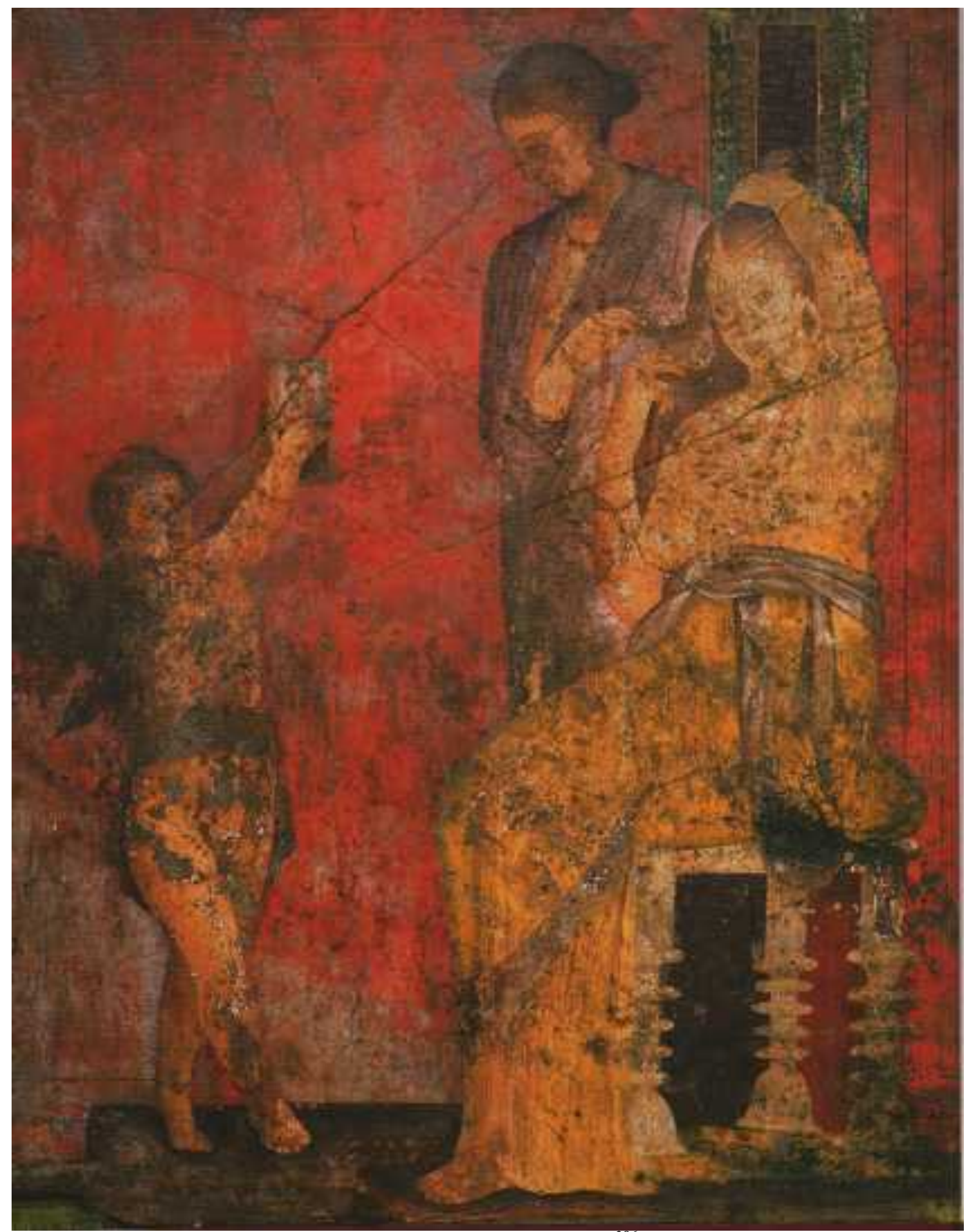

Figura 26. Cupido com noiva ${ }^{386}$

\footnotetext{
${ }^{385}$ Segundo Ling (2009:103), o penteado é característico de noiva; outros interpretam a figura como uma sacerdotisa dos mistérios dionisíacos.

${ }^{386}$ Pompeia, Vila dos Mistérios, estrada para Porta Ercolano. Construção: século II a.C; pinturas: 50-60 a.C.; oecus 5. Talvez este seja um raro exemplar de megalografia, pintura de grandes proporções, ou,
} 
Na parede ao lado, outro Cupido posiciona-se em pé sobre um pedestal, com a perna direita cruzada à frente da esquerda, segurando o arco com a mão esquerda e apoiando o queixo com a direita; a face está levemente inclinada para cima e os olhos atentos:

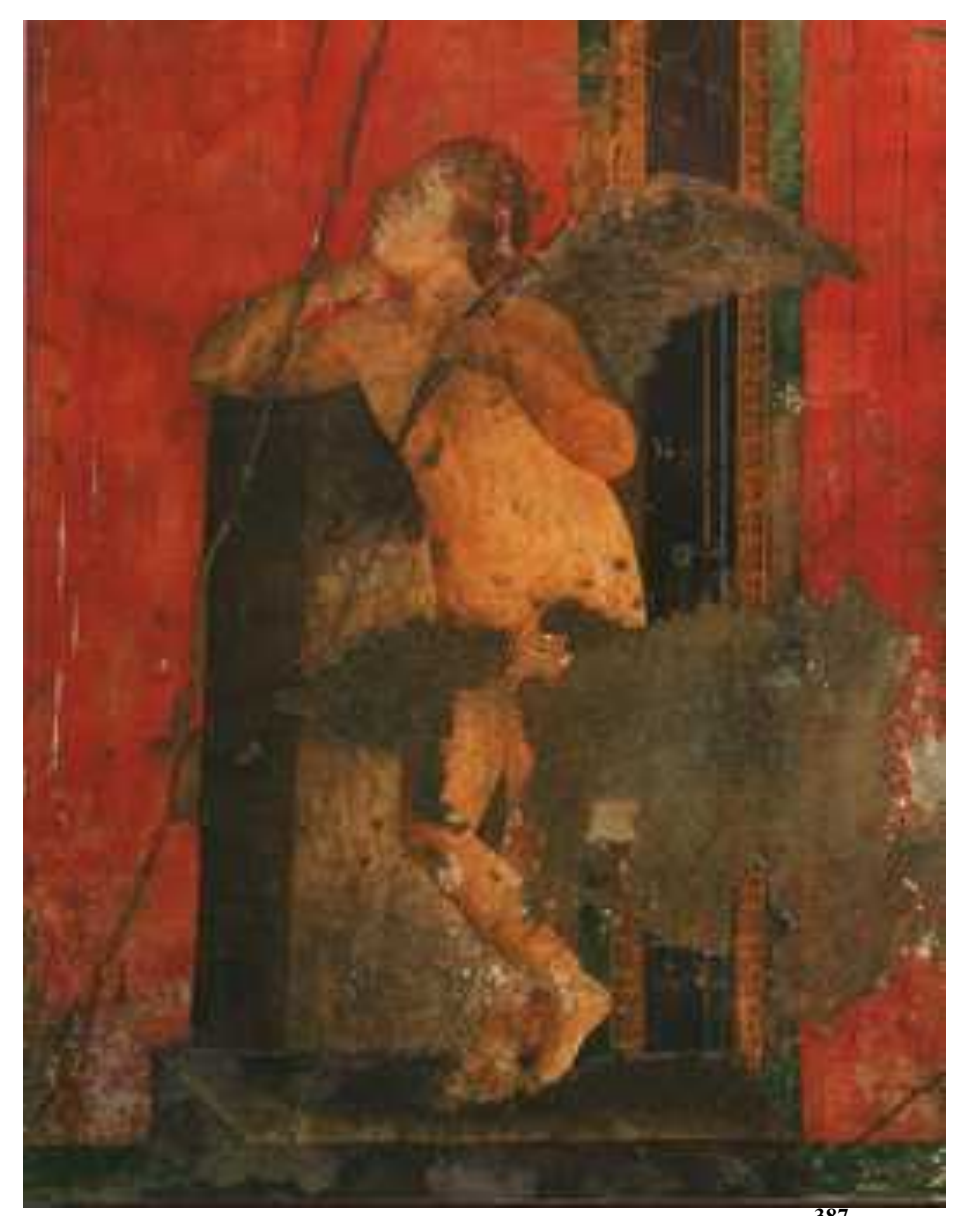

Figura 27. Cupido com arco sobre um pedestal ${ }^{38}$

Segundo Guerreri ${ }^{388}$ o casamento para as mulheres no mundo grego consistia em um rito de passagem, após o qual ela passaria a cumprir a função da reprodução e da administração do oikos. Por meio desse rito, sua relação amorosa se transformaria em relação social. Eros aparece nesse contexto com a função de presidir as relações pessoais na idade adulta. Para essa autora, na arte grega do final do século VI a.C. até a metade do século V a.C., havia maior interesse pela figuração de relações homossexuais entre homens, em especial do amor efébico; o interesse em retratar a vida heterossexual

segundo Vitrúvio megalografia (signorum megalografia, De Arch., 7.5.2), pintura que tira seus modelos de estátuas.

${ }^{387}$ Pompeia, Vila dos Mistérios, estrada para Porta Ercolano. Oecus 5. 50-60 a.C..

${ }^{388}$ Guerreri (2007:32). 
fortaleceu-se a partir da metade do século V a.C., quando a presença de Eros tornou-se mais comum no universo feminino, significando não apenas paixão e desejo erótico, mas certa glorificação do aspecto feminino e do casamento. Em suma, para a autora, nesse período, Eros começou a tomar parte da vida no gineceu, em cenas de jogos, música, e em preparação para o casamento. No mundo romano, a figuração de Eros em cenas de casamento pode ser observada na poesia e em outras artes, como podemos notar pelos exemplos mencionados acima.

Embora Amor possa agir como veículo da atração, ou como um elo de ligação entre os amantes, ele pode ser observado sob outro ponto de vista: como um personagem dos jogos amorosos. Em Odes 4.13, cuja matéria erótica possui paralelos com a 4.1, o amor é associado ao tempo em uma espécie de inversão do carpe diem, com o tema da perda dos dons de Vênus ${ }^{389}$. Putnam ${ }^{390}$ compara Amor ao tempo, observando que ambos podem voar, são emblemas da rapidez e podem aprisionar. $\mathrm{O}$ tempo alado arrasta os amantes para longe de Vênus e dos Cupidos. Em Odes 4.13, Lice é uma velha que, relutante em aceitar a passagem do tempo, participa de festas, bebe e desfruta dos prazeres como se fosse uma moça:

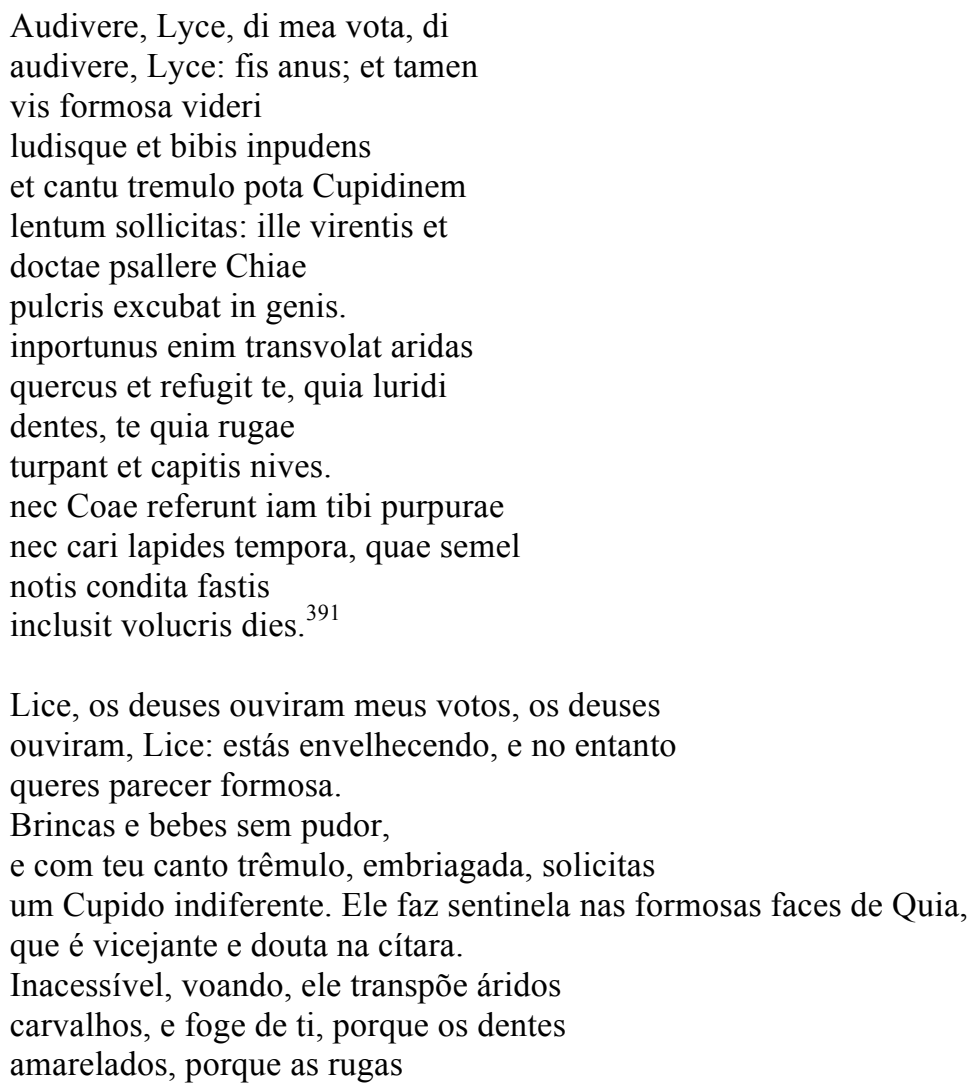

\footnotetext{
${ }^{389}$ Dettmer (1983:496).

${ }^{390}$ Putnam (1986:224).

${ }^{391}$ Hor., Carm. 4.13.1-19.
} 
e as neves da fronte te enfeiam.

Nem as vestes purpúreas de Cós,

nem valiosas pedras preciosas te restituem

os dias que uma vez o tempo alado encerrou

no registro dos conhecidos fastos.

Ela tenta atrair Cupido de maneira insistente (sollicitare), porém sua aparência decrépita e comportamento violento causam-lhe repulsa. Nos defrontamos aqui com a costumeira situação ambígua, em que não há como distinguir entre o objeto de desejo e o Amor personificado. Quinn ${ }^{392}$ interpreta "Cupido" como uma metáfora para a clientela masculina de Lice:

\begin{abstract}
by her song-and-dance act Lyce seeks to arouse sexual desires of her male audience; the modern editor has to print Cupidinem with a capital since the clause following refers to Cupid, thus spoiling the ambiguity. Horace plays with the fancy that Cupid is present in the party scene, reacting to Lyce's act as the men react - it is Chia who holds his attention, for Lyce he has no more than a passing glance.
\end{abstract}

A metáfora de Cupido para referir-se a homem desejado, leva-nos a observar o deus como objeto de desejo e não como o costumeiro agente externo que diverte-se no papel de causador da paixão; ele mesmo está inserido no jogo do amor como "caça", tal como Ligurino é presa de Horácio na ode 4.1.

Chia, outra mulher mencionada no poema, é a antítese de Lice: enquanto esta última repele, a primeira atrai Cupido. Principalmente aparência e vigor são quesitos fundamentais nesse mecanismo de atração e repulsa: por um lado, ele não interessa-se por Lice, porque ela perdeu todo o seu vigor e beleza, e de outro lado, é atraído pelo frescor da juventude que reside nas maçãs do rosto de Chia ${ }^{393}$; ela é jovem, bela e douta na cítara, como Lice um dia foi. Cupido não responde (lentus) ao apelo de Lice e incomoda-se (importunus) com sua aparência plena de rugas, dentes amarelados e cabelos brancos, e foge, atravessando florestas de carvalho, voando em direção oposta, em busca de Chia.

Considerando-se a atitude de Cupido com relação a Chia, ele desempenha o papel de guardião ou custos, que se nota pelo uso do verbo excubare $e^{394}$, que pertence ao jargão militar, e que merece uma discussão à parte, sendo um lugar-comum da tópica seruitium amoris e militia amoris. Quinn ${ }^{395}$ chama atenção para a atitude corporal do

\footnotetext{
${ }^{392}$ Quinn (1980:322).

${ }^{393}$ Virentis pulchrae genae. Maçãs do rosto como assento da beleza feminina, onde Eros fixa residência, cf. Thomas (2011:239).

${ }_{394}$ A ação de Eros montando guarda pode ser observada em Sophocles, Antigone 784.

${ }^{395}$ Quinn (2002:322).
} 
deus nesse poema, em que ele mantém seus olhos fixos na bela face de Chia, tal como o vigia em guerra que monta guarda à noite e mantém-se alerta enquanto os outros dormem; ele observa Chia do mesmo modo que Propércio observa Cíntia, ou Argos, Io $^{396}$. Por hora, basta lembrarmos que o ato de montar guarda, vigiar ou olhar atentamente, aplicado ao contexto erótico nesse poema, indica que Cupido não só provoca atração como também é atraído pela beleza, forma e vigor, em suma, pelos atributos de Vênus.

Desse modo, a fim de atrair Cupido, uma mulher deve ter venus, algo que Chia, possui, e que Lice, por sua vez, perdeu. Tudo o que restou para esta última é o escárnio dos moços, que rirão ao observá-la desfazer-se em cinzas como uma tocha consumida, como diz Horácio em uma enfática interrogatio:

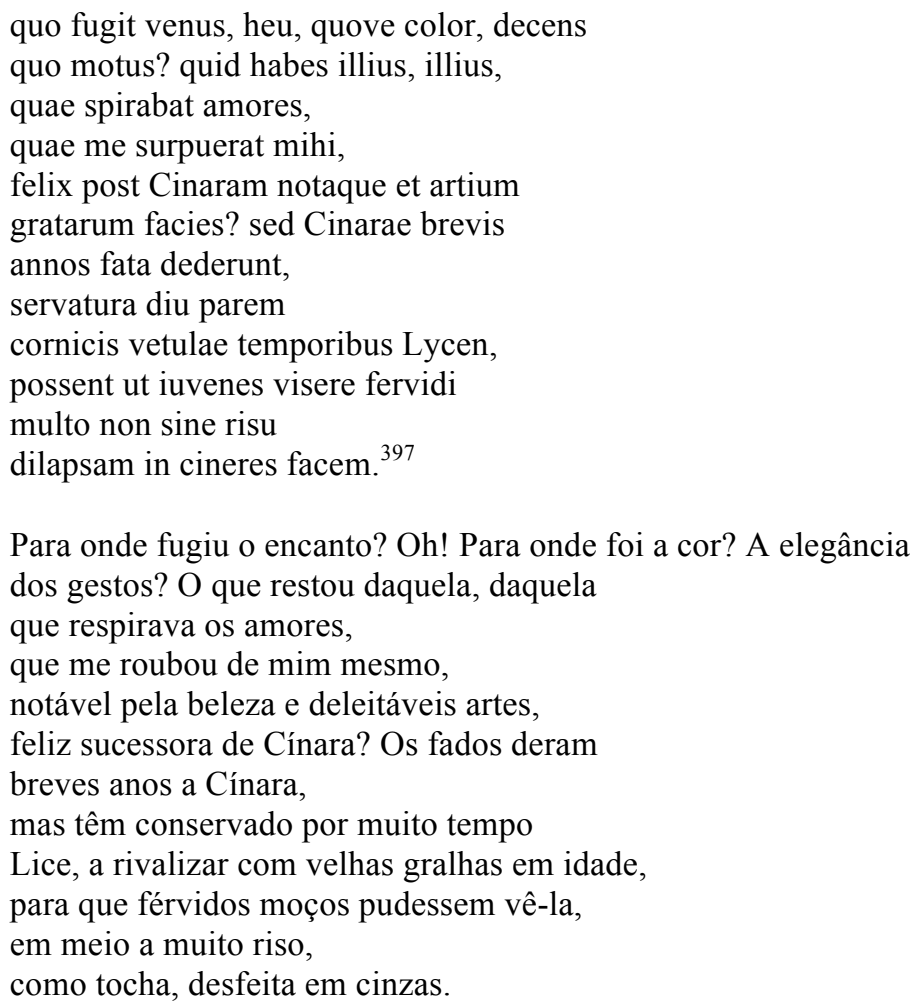

O tema da pintura abaixo, de acordo com o catálogo do Museu Britânico, é: Mulher tentada por Cupido. Ela está sentada em uma poltrona, com parte do corpo coberta por uma túnica translúcida e um manto sobre as pernas; nos seus cabelos há sinais de um adorno (rede) dourado; ela segura delicadamente um véu ou manto com a mão esquerda, enquanto o braço direito acomoda-se na poltrona. Cupido inclina-se ao lado dela, segurando um leque com a mão direita, e a palma de sua mão esquerda está voltada para cima. Os olhares de ambos estão atentos um para o outro:

\footnotetext{
${ }^{396}$ Propércio (1.3.19-20) observando Cíntia com olhar fixo como Argos vigiando Io.

${ }^{397}$ Hor., Carm. 4.13.17-28.
} 


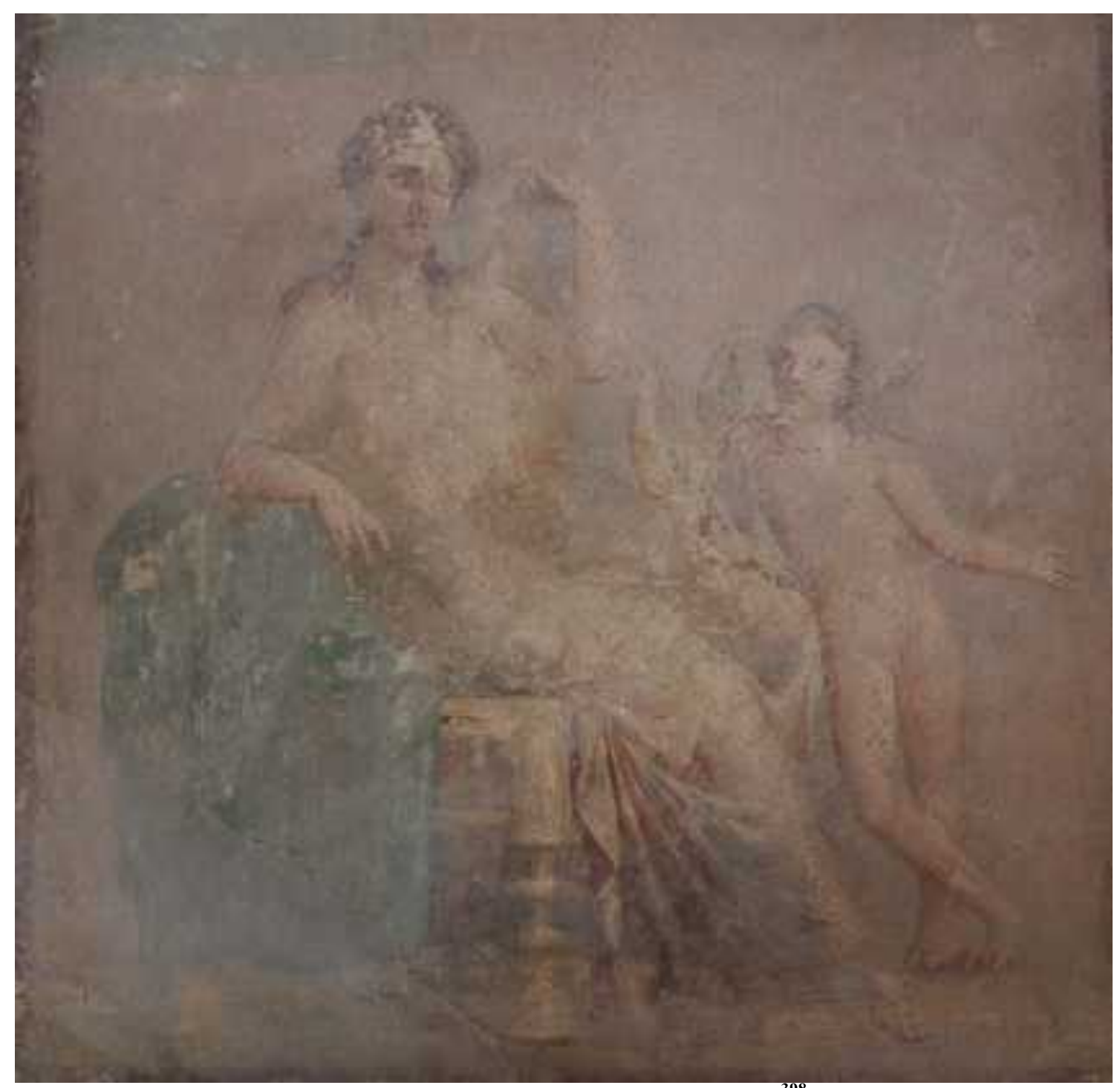

Figura 28. Cupido seduzindo uma mulher ${ }^{398}$

Essa mulher possui alguns dos atributos e atitudes de Vênus ${ }^{399}$, que já observamos em outras figuras. Cupido aparece como flabellifer, segurando o leque (flabellum) de folha de lótus ${ }^{400}$, que, segundo Beeson ${ }^{401}$, pode ser encontrado nas mais diversas artes como um dos atributos de Afrodite desde a Grécia Arcaica. Segundo o autor, embora o leque seja um atributo dessa deusa, nem todas as mulheres figuradas

\footnotetext{
${ }^{398}$ The British Museum. Ref. number: 1857,0415.3. Cupid tempting a woman. Wall-painting. Materials: plaster (?). Techniques: painted. Place: Excavated/Findspot Casa di Meleagro (Pompeii). Period/Culture: Roman: Description: Wall painting: woman seated to left in a gilt armchair, with a transparent white chiton over her upper body and a red mantle over her legs; to the right stands Cupid, resting his elbow on her right knee and holding a leaf-shaped fan; grey background, dark red border. Dimensions: Height: 48.5 centimetres. Width: 46.5 centimetres. For Cupid with the attitude see also: Artemis and Calisto. Pompeii. Casa de L. Cornelius Diadumenus. Inv. 111441.

${ }^{399}$ Cf.: Ares and Aphrodite. Pompeii, Casa di Meleagro. VI 9.2.13, tablinum 8, south wall. Inv. 9256. Idem, cubiculum 12, east wall. Casa delle Nozze di Ercole, Pompeii, VII 9, 47. Inv. 9248.

${ }^{400}$ Cupido com leque também na pintura Ariadne abandonada, Casa de Meleagro. Museu de Nápoles; inv. 9051.

${ }^{401}$ Beeson (1995:4).
} 
com ele são Vênus; ele aparece em pinturas de Pompeia nas mãos de Cupido acompanhado ou não de Vênus, e também nas mãos de Galateia, Ônfale, e de outras mulheres nobres, como símbolo de autoridade, luxo e dolce far niente. Se não podemos afirmar que a mulher tentada por Cupido da Casa de Meleagro é Vênus, ao menos os seus atributos e a sua atitude indicam que ela possui venus, isto é a beleza e a forma que atraem Cupido.

\section{Amor e Psiquê}

Já observamos alguns exemplos da presença de Eros em cenas de casamento na poesia e em outras artes em Roma. O seu envolvimento amoroso e casamento com Psiquê pode ser observado nas artes, porém raras são as menções a esse tema na poesia latina, sendo a principal referência encontrada nas Metamorfoses ${ }^{402}$ de Apuleio, da segunda metade do século II d.C.. Segundo Relihan ${ }^{403}$, nas Metamorfoses, Cupido cresce, transformando-se no jovem oportunista que viola as ordens de sua mãe e dorme com Psiquê em vez de sacrificá-la ao monstro, e que, ao mesmo tempo, pune sua amada por desobecer à sua proibição de conhecer sua verdadeira identidade; até que, por fim, depois de muito sofrimento, torna-se o esposo que abertamente proclama o seu amor. A trama ecoa elementos do Simpósio e do Fedro de Platão, do De Rerum Natura de Lucrécio e da poesia latina, especialmente na caracterização de Cupido, Vênus e Psiquê.

Kenney ${ }^{404}$ observa que a beleza é um ingrediente fundamental nessa relação amorosa para ambas as partes: Cupido apaixona-se por Psiquê encantado com sua extrema beleza, que causa a inveja e a ira de Vênus; e Psiquê, por sua vez, não se apaixonou por Cupido até que pudesse vê-lo: o que antes não passava de mero desejo transforma-se em um desejo insaciável de perseguir Amor para sempre:

\footnotetext{
Quae dum insatiabili animo Psyche, satis et curiosa, rimatur atque pertrectat et mariti sui miratur arma, depromit unam de pharetra sagittam et punctu pollicis extremam aciem periclitabunda trementis etiam nunc articuli nisu fortiore pupugit altius, ut per summam cutem rorauerint paruulae sanguinis rosei guttae. Sic ignara Psyche sponte in Amoris incidit amorem. Tunc magis magisque cupidine fraglans Cupidinis prona in eum efflictim inhians patulis ac petulantibus sauiis festinanter ingestis de somni mensura metuebat. ${ }^{405}$

Psiquê, sem poder conter-se, com sua inata curiosidade, examina, toca e maravilha-
}

\footnotetext{
${ }^{402}$ Apul., Met. 4.28-6.24.

${ }^{403}$ Relihan (2007:Introd.xxiii)

${ }^{404}$ Kenney (1990:171).

${ }^{405}$ Apul., Met. 5.23.10.
} 
se com as armas do marido. Ela tirou uma das setas da aljava, e testou a ponta contra o dedo, mas como suas mãos ainda tremessem, ela pressionou com tanta força que a ponta entrou, e gotas vermelhas de sangue escorreram na superfície de sua pele. Então, sem saber, Psiquê, por seu próprio ato, caiu de amores por Amor. Assim, mais e mais ardendo de desejo por Cupido, ela inclinou-se sobre ele, fitando-o ofegante; e cobriu-o de beijos apaixonados e impetuosos, temendo despertá-lo do sono.

Ao ser descoberta, ela é rejeitada por Amor, e depois de uma sucessão de amarguras e sofrimentos, Júpiter concede que o casal reate, promovendo um banquete no Olimpo para celebrar a união, da qual nasce uma filha chamada Voluptuosidade, o prazer personificado:

Sic rite Psyche conuenit in manum Cupidinis et nascitur illis maturo partu filia, quam Voluptatem nominamus'. ${ }^{406}$

Por esses ritos Psiquê casou-se com Cupido e no momento oportuno dessa união nasceu uma filha, que chamamos de Voluptuosidade.

Antes do texto de Apuleio ser publicado, pelo menos desde o final da República em Roma, o tema de Eros e Psiquê proliferava nas artes, em pinturas de Pompeia, das quais observamos alguns exemplos anteriormente, e também em gemas como esta abaixo, nesta cena de um ritual, possivelmente um casamento. O primeiro Cupido, à esquerda, carrega uma espécie de bandeja, possivelmente com oferendas; o segundo, com a cabeça coberta, tem um laço amarrado ao pescoço e segura uma ave; e é conduzido por um terceiro, que carrega uma tocha e caminha em direção a uma banqueta que está sendo descoberta pelo quarto Cupido; que, por sua vez, faz um gesto como se indicasse que o assento deve ser ocupado. Psiquê, ao lado do Cupido vendado, encontra-se com a cabeça coberta por um véu e veste uma túnica comprida:

${ }^{406}$ Apul., Met. 6.25.1. 


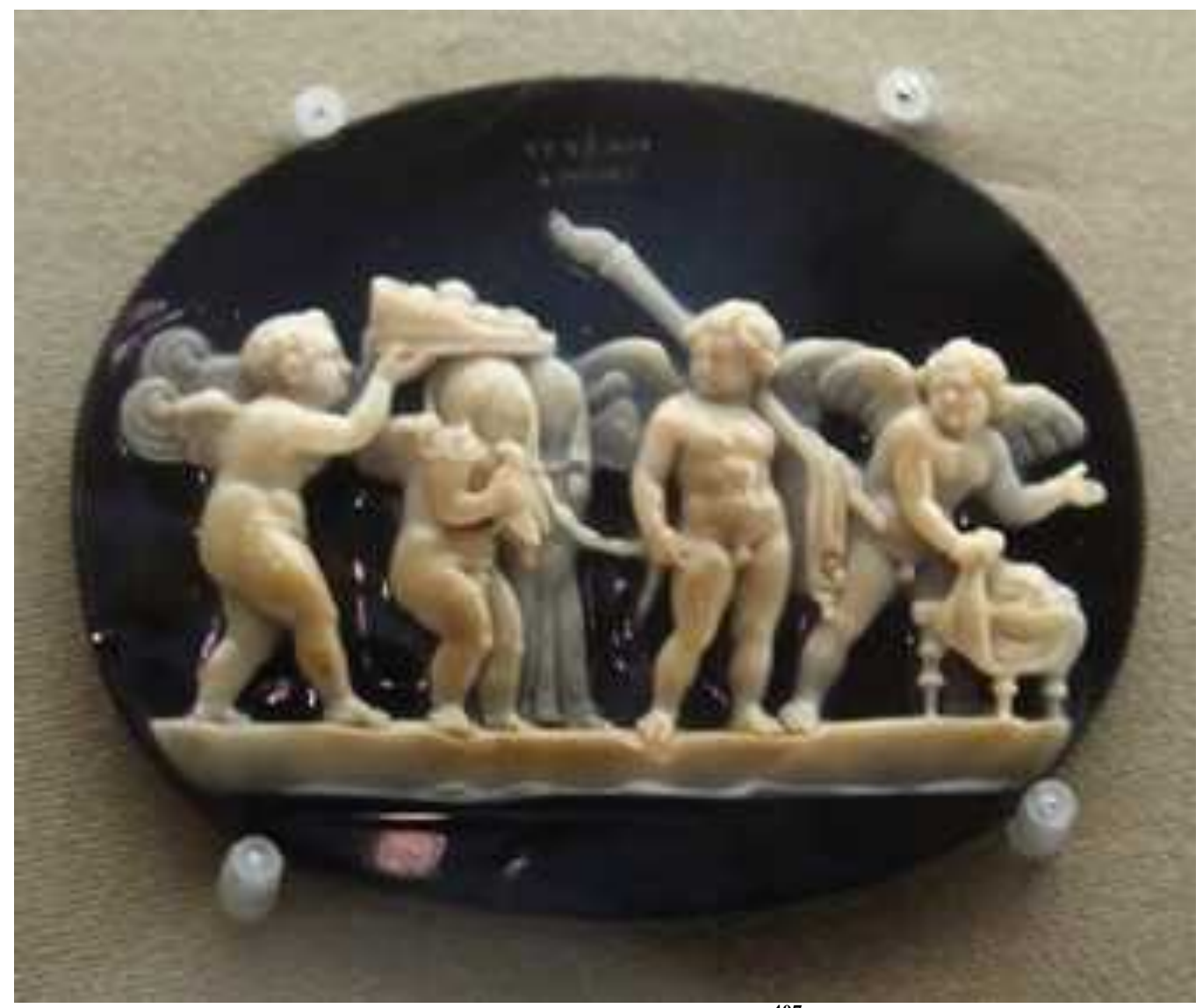

Figura 29. Amorini e Psiquêt

Em suma, Cupido pode ser percebido como objeto de paixão ou apaixonar-se, envolvendo-se nos jogos amorosos. Sua relação especificamente com Psiquê é mais comum nas artes do que na poesia latina.

${ }^{407}$ MFA, Boston. Accession number: 99.101. Cameo with the wedding of Cupid and Psyche, or an initiation rite. Roman, Late Republican or Early Imperial Period, mid 1st-late 1st century B.C. Signed by Tryphon. Dimensions: Overall: 3.7 x 4.5 x 0.6 cm (1 7/16 x $13 / 4$ x 1/4 in.). Medium or technique: Onyx. Classification: Jewelry / Adornment. Catalogue Raisonné. Highlights: Classical Art, p. 091. 


\section{Militia Amoris}

A militia amoris, a paradoxal guerra de Vênus e Cupido, aparece na poesia latina inicialmente como um locus, que gradativamente assume maiores proporções. A mais antiga referência ao poder bélico desses deuses na poesia latina é de Plauto, que diz ter sido atingido no peito pela seta de Cupido: Saucius factus sum in Veneris proelio: sagittá Cupido cor meum transfixit. ${ }^{408}$ (Fui ferido no combate de Vênus: Cupido transpassou meu coração com sua flecha). Terêncio ${ }^{409}$, por sua vez, fala dos paradoxos do amor: in amore haec omnia insunt vitia: iniuriae, suspiciones, inimicitiae, indutiae, bellum, pax rursum (todos esses vícios são inerentes ao amor: injustiças, desconfianças, inimizades, tréguas, guerra, paz de novo). Catulo introduz o tema das batalhas com a amada $^{410}$; e Horácio, por sua vez, como vimos em Odes 4.1, tenta recusar o chamado para retornar às batalhas de Vênus, mas acaba caindo presa dos Amores. Os elegíacos Propércio, Ovídio e Tibulo ampliaram este locus, transformando-o em uma tópica fundamental da elegia augustana ${ }^{411}$. Segundo Veyne ${ }^{412}$, na elegia erótica romana, "a apologia do prazer e da milícia do amor é um divertido paradoxo", que pode ser observado nos primeiros versos de Amores 1.9:

\footnotetext{
Militat omnis amans, et habet sua castra Cupido; Attice, crede mihi, militat omnis amans. quae bello est habilis, Veneri quoque convenit aetas. turpe senex miles, turpe senilis amor. quos petiere duces animos in milite forti, hos petit in socio bella puella viro. ${ }^{413}$

Todo amante milita, e Cupido possui seu quartel; Ático, crê em mim, todo amante milita. A idade própria para guerra também compete a Vênus. A militância é torpe para um velho, é torpe o amor senil. O ânimo que o comandante requer do valente soldado, é o mesmo que a bela dama pede ao seu parceiro.
}

Booth $^{414}$ observa que todos os aspectos da vida do amante são comparados com a do soldado, uma ocupação para os jovens e fortes, e não para os preguiçosos e velhos; ambas envolvem a guarda e o ataque em um campo de batalha ou diante de portas fechadas.

\footnotetext{
${ }^{408}$ P1., Per. 25.

${ }^{409}$ Ter., Eu. 59-61.

${ }^{410}$ Cat., Carm. 11-14.

${ }^{411}$ Sobre militia amoris, cf. Mckeown (1995:302), Thomas (1964), Kennedy (1993).

${ }^{412}$ Veyne (1985:232).

${ }^{413}$ Ov., Am. 1.9.1-6.

${ }^{414}$ Booth (2009:69). In: Knox (ed.) A Companion to Ovid. Malden: Wiley Blackwell.
} 
A temática militar no discurso elegíaco augustano se dá por meio da negação dos temas épicos e do serviço militar, em favor da poesia e do ócio. A recusatio da guerra introduz nos poemas uma linguagem de contradições em que prevalecem paradoxos, ambiguidades e ironias. Gale ${ }^{415}$, referindo-se ao público da elegia de Propércio, lembra que:

\begin{abstract}
a maior parte da audiência é caracterizada como hostil (ou, pelo menos, não estaria automaticamente de acordo) aos ideais que o poeta ${ }^{416}$ proclama. Isso contribui para que se entenda como uso da ironia, uma vez que nos distanciamos do emissor do discurso e somos alertados de que ele, ao invés de "senes duri", no final, se torna alvo de sua própria zombaria.
\end{abstract}

Dos antecedentes gregos, os poetas latinos utilizaram na militia amoris a ambivalente figura do Eros arqueiro que Eurípedes apresenta em Hipólito ${ }^{417}$. No hino das mulheres de Trezena, o deus destila pothos pelo olhar e penetra na alma (psykhê), despertando o prazer pela doçura; e por outro lado, ele é o tirano cuja ação é caracterizada como um ataque que ele empreende como membro do séquito de Afrodite. Para Calame ${ }^{418}$, a paradoxal imagem de Eros apresentada pelo coro o caracteriza como um "soldado do prazer".

A contrastante imagem do Eros arqueiro foi utilizada pelos poetas alexandrinos, especialmente Possidipo, Meleagro e Asclepíades, que enfatizam o poder das incandescentes flechas lançadas pelo penetrante olhar do provocativo menino, que transpassa suas vítimas acertando o coração, como vimos em vários exemplos mencionados anteriormente ${ }^{419}$. Este epigrama, abaixo, de Meleagro, evidencia as turbulências nos domínios de Afrodite, a violência dos ataques, as amarguras e o olhar como principal arma de sedução:

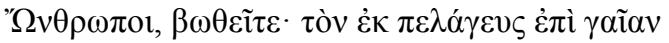

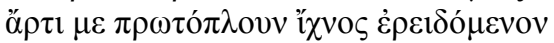

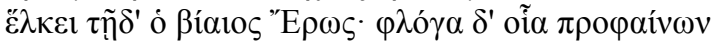

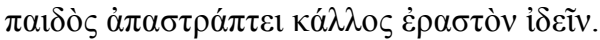

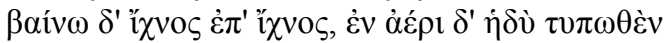
$\varepsilon \tilde{i} \delta \circ \zeta \dot{\alpha} \varphi \alpha \rho \pi \alpha \dot{\zeta} \omega v \chi \varepsilon \dot{\imath} \lambda \varepsilon \sigma \mathrm{v} v \dot{\eta} \delta \grave{v} \varphi \imath \lambda \tilde{\omega}$.

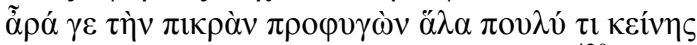

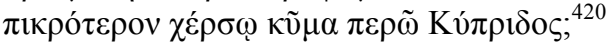

Homens, socorro! Recém desembarcado do mar

\footnotetext{
${ }^{415}$ Gale (1997:83).

${ }^{416}$ Nessa passagem a autora está se referindo a Propércio, mas a sugestão, a meu ver, vale para Tibulo e Ovídio também.

417 Ésquilo, Hipólito 525-ss..

418 Calame (1999:6).

${ }^{419}$ Meleagro, A. P. 5.177 e 178

${ }^{420}$ Meleagro, A. P. 12.84 .
} 
ainda a pouco em terra pisei, depois de navegar

e Eros violento arrastou-me aqui: como se iluminasse com uma chama

o garoto resplendeu para que eu visse sua adorável beleza.

Sigo-o passo a passo e tento tomar a doce forma desenhada

no ar, beijando-a docemente com meus lábios.

Será que escapei do mar acerbo para em terra firme cruzar com

uma onda de Cípris bem mais amarga? $?^{421}$

A tópica militia amoris é indissociável da seruitium amoris; essa relação de interdependência é observável pela lógica militar: todo aquele que comanda ou que serve a um exército, tem por finalidade subjugar o adversário, alcançar a vitória, proceder ao triunfo, e por fim, excecer a supremacia, escravizando o cativo.

\section{Marte, Vênus e Cupido: uma família de deuses do amor e da guerra em}

\section{Roma}

Em Roma é evidente a relação entre Vênus, Marte e Cupido como uma família. A união entre os deuses do amor e da guerra soa paradoxal ao unir dois opostos que seriam irreconciliáveis ${ }^{422}$, porém é tão paradoxal quanto o caráter do filho, e encaixa-se perfeitamente no contexto da tópica militia amoris. Mencionamos anteriormente as genealogias $^{423}$ de Cupido no De Natura Deorum de Cícero, entre as quais há uma que diz que Anteros é fruto de um amor adúltero entre Marte e a terceira Vênus, esposa de Hefesto $^{424}$. Há pinturas que também sugerem o parentesco entre esses deuses; uma delas é o afresco abaixo, em que figuram Ares e Afrodite posicionados ao centro, na presença de uma ama ajoelhada à esquerda, e de Cupido que, voando à direita, tem o olhar voltado para o centro da figura. A deusa, sentada em um trono, com um diadema adornando os cabelos e vestindo uma túnica longa que deixa um dos seios à mostra, recebe os afagos de Ares, que tem a cabeça adornada por um elmo e na mão direita uma lança, posicionado atrás do trono:

\footnotetext{
${ }^{421}$ Tradução de F. V. Amaral.

422 Lausberg (2004:230).

${ }^{423}$ Spencer (1932:130-131) fornece um levantamento completo das possíveis linhagem do Cupido. Nock $(1924: 153)$ também discute em detalhes as genealogias do deus.

${ }^{424}$ Cic., N. D. 3.59 .
} 


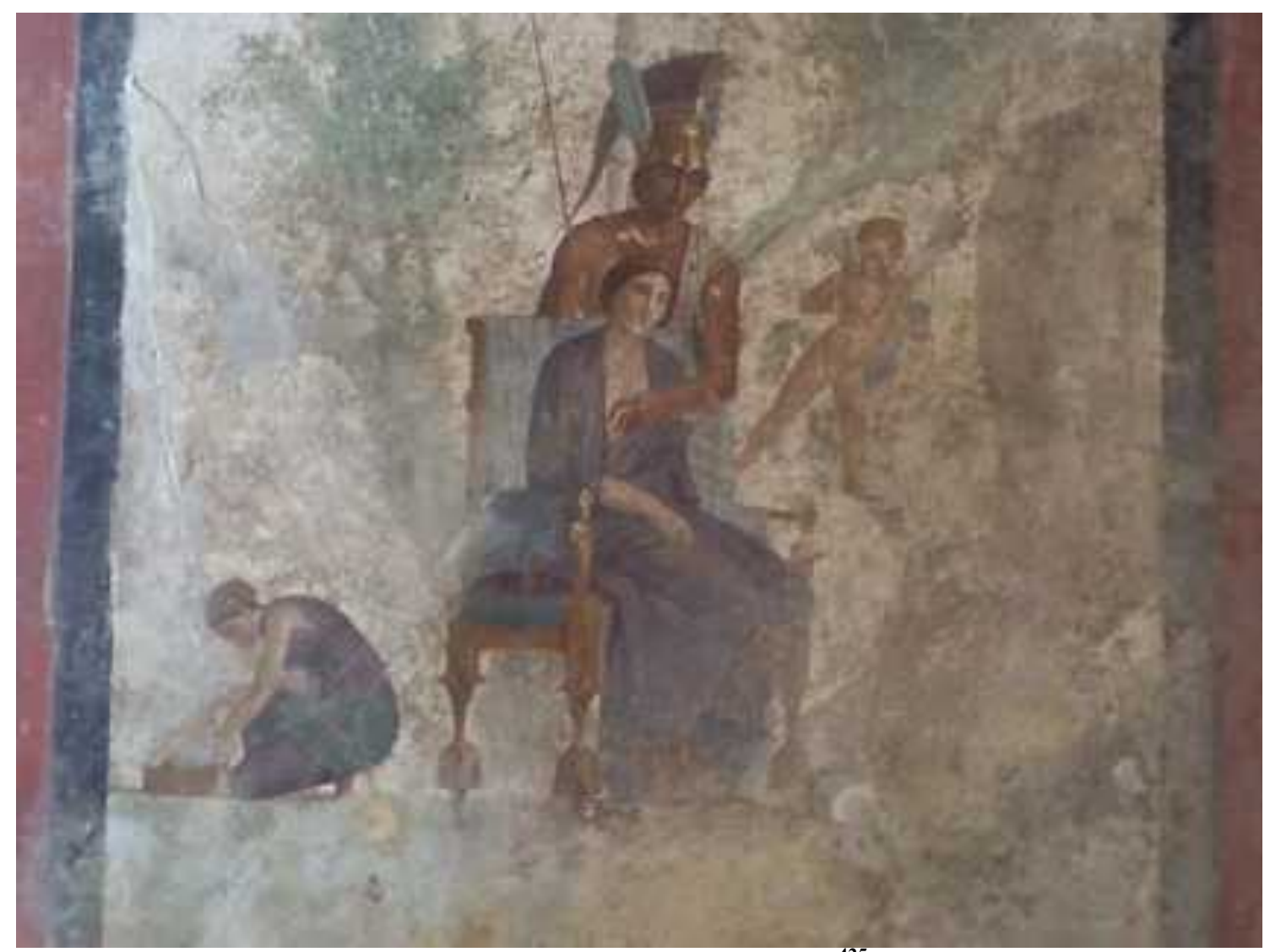

Figura 30. Marte, Vênus e Cupido

Há várias pinturas de Pompeia que apresentam essa mesma iconografia que sugere o tema do casamento, uma delas a do tablinum da Casa de Marco Lucrécio Fontro, que vimos anteriormente. Para Sampaolo ${ }^{426}$, a atitude graciosa e a moderação dessas figuras é própria da cultura propagada durante o período augustano, em contraposição à figuração mais sensual do período neroniano ${ }^{427}$, exemplo da qual observaremos mais adiante.

Os poetas elegíacos são os que mais enfatizam o parentesco entre Cupido e Marte. Ovídio, em Amores 2.9b, emprega dois termos que reforçam essa associação: priuigne, enteado, para Cupido, e uitricus, padrasto, para Marte ${ }^{428}$ :

Quod dubius Mars est, per te, privigne Cupido, est; et movet exemplo vitricus arma tuo. tu levis es multoque tuis ventosior alis, gaudiaque ambigua dasque negasque fide. si tamen exaudis, pulchra cum matre, Cupido,

\footnotetext{
${ }^{425}$ Museo Archeologico Nazionale di Napoli, Nápoles, Itália. Inv. 9249. Ares e Afrodite. Pompei, Casa dell'Amore Punito. VII 2, 23 tablino (f), parete sud. Alt. cm. 154; largh. cm 117; 1-25 d.C..

${ }^{426}$ Sampaolo (2009:256).

${ }^{427}$ Ares e Afrodite: Museo Archeologico Nazionale di Napoli, Napoli, Itália. Inv. 9248; e Inv. 9256.

${ }^{428}$ Marte como padrasto (uitricus) de Cupido, cf. Ov., Rem. Am. 1.27.
} 
indeserta meo pectore regna gere!

accedant regno, nimium vaga turba, puellae!

ambobus populis sic venerandus eris. ${ }^{429}$

É por tua causa, enteado Cupido, que Marte é dúbio,

Pois o padrasto move as armas segundo o teu exemplo.

Tu és ainda mais rápido que o vento com tuas leves asas

Tu concedes e negas alegrias com lealdade ambígua.

Se ouvires as minhas súplicas, Cupido, com tua bela mãe,

vem, estabelece o teu reino em meu peito para nunca mais sair.

Que a turba errante de meninas junte-se ao teu reino!

Assim, serás venerado por todo o povo.

Enquanto no texto de Cícero Anteros é caracterizado com filho de Vênus e Marte, os poetas latinos preservaram a dúvida sobre sua paternidade, mencionando sempre um padrasto, normalmente Marte, e possivelmente Vulcano; ambos amores de Afrodite na poesia latina. Ovídio, por exemplo, em Amores $1.2^{430}$, menciona o padrasto sem dizer seu nome, deixando para o leitor decidir entre Vulcano, hábil nas artes, ou Marte, associado ao triunfo, como aquele que presenteou Cupido com a carruagem utilizada em sua procissão triunfal. A incógnita sobre a paternidade de Cupido também é comum epigramas, como este de Meleagro, em que Eros possui traços de Hefesto e de Ares:

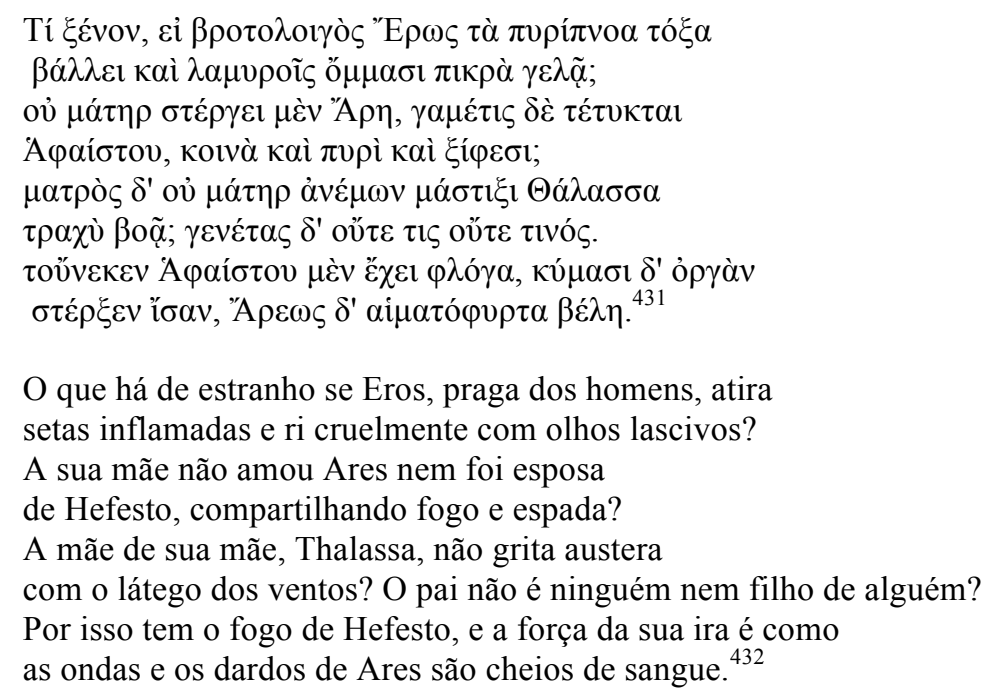

Augusto dedicou, em 2 a.C., no Fórum, o templo de Marte Ultor, em honra ao deus por sua vitória sobre os assassinos de Júlio César, um lugar que tornou-se o centro das atividades ligadas à paz e à guerra em Roma. Ovídio menciona, nos Tristia, a

\footnotetext{
${ }^{429}$ Ov., Am. 2.9b.47-54.

${ }^{430}$ Ov., Am. 1.2.24: currum vitricus ipse dabit.

${ }^{431}$ Meleagro, A. P. 5.180.

${ }^{432}$ Tradução de F. V. Amaral.
} 
presença de Vênus no Templo de Marte Ultor: venerit in magni templum, tua munera, Martis, stat Venus Vltori iuncta, vir ante fores ${ }^{433}$. (Se ela entrar no templo do poderoso Marte, teu presente Vênus está junto ao Vingador, e um homem diante das portas). Segundo Miller ${ }^{434}$ nesse templo havia uma estátua de Vênus, como divindade tutelar da gens Iulia, ao lado de Marte, em uma representação alegórica da aliança do poder de guerra do clan. A palavra iuncta, que pode ser usada em referência ao casamento, também tem clara conotação sexual ${ }^{435}$, ligando a figura de Marte a Vênus, enquanto uma estátua de Vulcano (vir ante fores), marido da deusa, ficaria do lado de fora, reduzido à figura do exclusus amator, comum na poesia erótica latina. Henderson ${ }^{436}$ indica que provavelmente "tua munera", teu presente, são as estátuas de Vênus Genetrix e Marte de Arcesilau. A deusa possivelmente estava vestida com indumentária masculina, e Cupido posicionado entre as duas estátuas. Munus, segundo Adams ${ }^{437}$, em sentido erótico, pode significar "os serviços sexuais prestados ao parceiro" ${ }^{438}$, uma ambiguidade interessante nessa passagem que menciona um amor adúltero.

A passagem abaixo da Odisseia refere-se ao amor adúltero entre esses dois deuses:

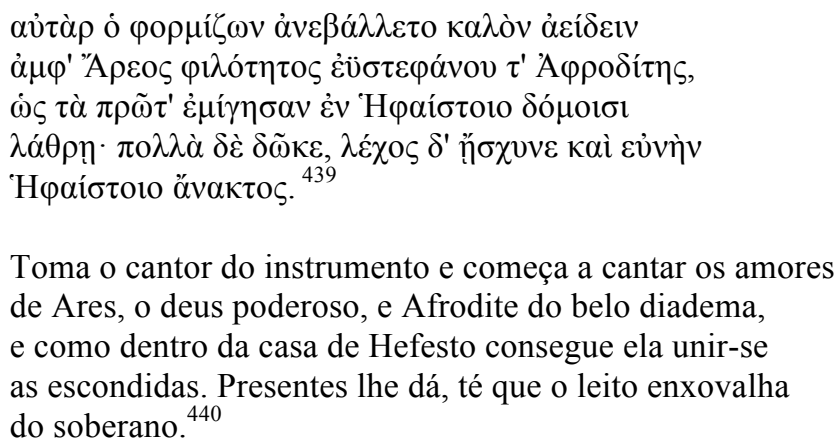

O relevo de Cartago, abaixo, provavelmente reproduz imagens que pertenceram ao templo de Marte Ultor ${ }^{441}$, com a presença de Marte ao centro, Vênus Genetrix com Cupido, que brinca com um gládio sob a sua veste, e possivelmente o Divo Júlio, à direita:

\footnotetext{
${ }^{433}$ Ov., Tr. 2.295-296.

${ }^{434}$ Miller (2002:295).

${ }^{435}$ Adams (2002:179).

${ }^{436}$ Henderson (1996:76).

${ }^{437}$ Adams (2002:164).

${ }^{438}$ Hor., Carm. 2.5.2, Cat., Carm. 61.227, Plaut., Asin. 812.

${ }^{439}$ Hom., Odisseia 8.266-270.

${ }^{440}$ Tradução de C. A. Nunes.

${ }^{441}$ Beard (1996:333), Zanker (1998:195).
} 


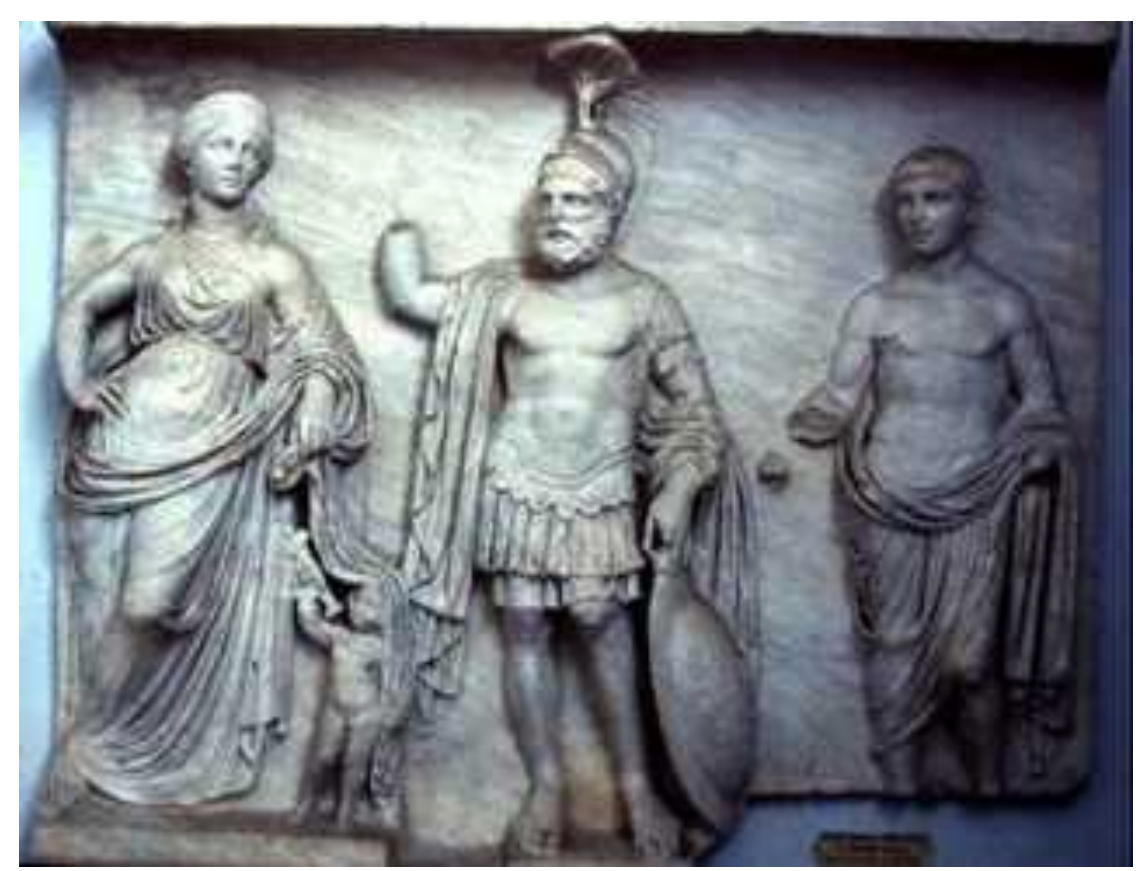

Figura 31. Marte, Vênus, Cupido e Divo Júlio ${ }^{42}$

Esse relevo reproduz na província aquilo que figura em destaque na capital, representado uma ideia amplamente divulgada por todo o território romano: a gens Iulia e o povo romano como descendentes de uma família de deuses que paradoxalmente simbolizam o amor e a guerra. Cupido, no papel de enteado de Marte, filho de Vênus e irmão de Eneias, seria o modelo perfeito para todos os romanos, que deveriam lutar como ele e sua família para defender os interesses militares da pátria.

Marte e Cupido, além do parentesco, têm em comum a crueldade e a habilidade no manejo das armas. Normalmente as armas de Marte são o gládio, a lança e o escudo, que aparecem nas mãos de Cupido em diversos relevos e pinturas; mas o contrário também ocorre, especialmente na poesia, em que Marte empunha as armas do enteado, como observamos nos versos: Quod dubius Mars est, per te, privigne Cupido, est; et movet exemplo vitricus arma tuo. Sabemos que o manejo dúbio das armas sugere metáfora sexual, e nesse sentido, Marte as move, não somente para fazer a guerra, mas também para fazer amor.

A pintura abaixo figura o tema do amor de Ares e Afrodite, que, segundo Sampaolo $^{443}$, possui mais de trinta versões em Pompeia, entre elas uma mencionada

\footnotetext{
${ }^{442}$ Museu Arqueológico, Algeria. Beard (1996:333): Left to right: Venus, Mars; probably divus Iulius, as strongly implied by the star on his forehead, rather than an Augustan Prince. Mars must be Mars Ultor, the cult-image from his own temple in the Forum Augustus. According to Kleiner, this relief imitates a group of statues which were inside the temple of Mars Ultor.

${ }^{443}$ Sampaolo (2009:354).
} 
anteriormente ${ }^{444}$ datada do período augustano. De acordo com esta autora, esse exemplar abaixo, do período neroniano, apresenta características helenísticas na distribuição em formato triangular das figuras e no equilíbrio entre os personagens. Essa pintura apresenta maior sensualidade do que aquela da Casa do Cupido Punido que vimos anteriormente, evidenciando com mais ênfase o tema do amor erótico do que especificamente o do casamento: Vênus reclina-se sobre o corpo do companheiro, adornada com joias por todo o corpo; ela prende delicadamente com os dedos a ponta da veste, e com a mão esquerda segura a longa lança de Marte, que por sua vez levanta o manto da deusa, revelando sua nudez. Dois Cupidos brincam com as armas e indumentária de Marte: no alto, em pé, um deles porta o gládio, enquanto o segundo, em posição inferior, veste o elmo:

\footnotetext{
${ }^{444}$ Museo Archeologico Nazionale di Napoli, Nápoles, Itália. Inv. 9249. Ares e Afrodite. Pompei, Casa
} dell'Amore Punito. 


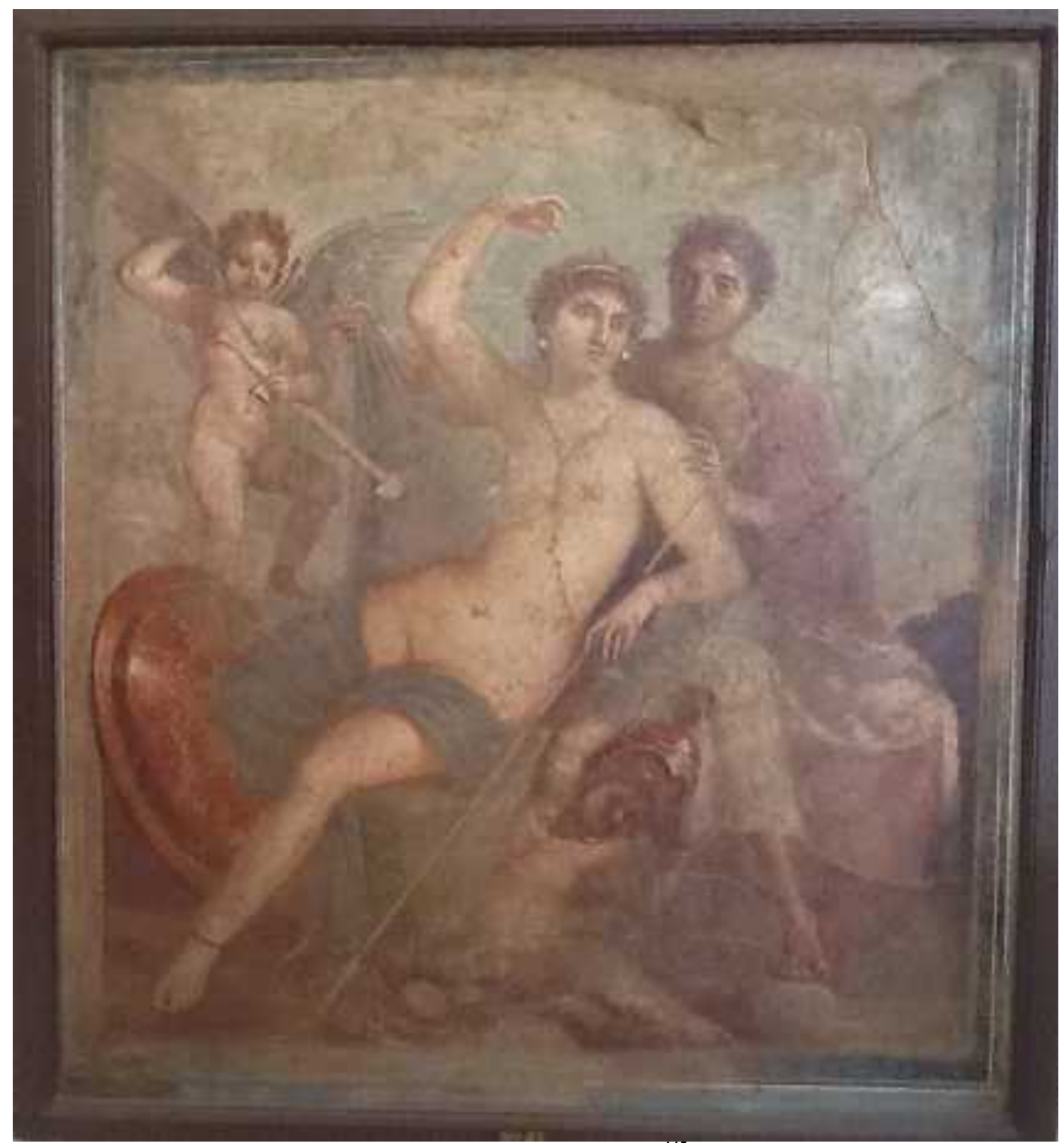

Figura 32. Ares e Afrodite ${ }^{445}$

Os dois Cupidos na presença desses deuses podem representar forças antagonistas como Eros e Anteros, divindades honradas em ginásios devido à sua associação ao combate, ou confronto entre opositores. Pausâniass ${ }^{446}$ menciona dois altares na Grécia dedicados a Anteros: um deles num ginásio em Élis, junto com Eros; e outro em Atenas, exclusivamente dedicado a Anteros como vingador do amor desprezado, que é mencionado na anedota de Meles e Timágoras, que envolve a paixão, o desprezo, o remorso e o suicídio.

\footnotetext{
${ }^{445}$ Museo Archeologico Nazionale di Napoli, Napoli, Itália. Inv. 9248. Ares e Afrodite. Pompeii, Casa di Marte e Venere o delle Nozze di Ercole. VII 9, 47. Alt: 99 cm.; Larg: 90 cm; $45-79$ d.C..

${ }^{446}$ Paus., 1.30 .
} 
Nessa dupla face do deus também reside o poder divino de criar efeitos contrastantes em sua esfera de atividade; no que concerne ao amor, enquanto Eros tem o poder de desencadeá-lo, seu irmão Anteros pode vingá-lo, ou até mesmo, numa concepção platônica, retribui-lo ${ }^{447}$. Embora o nome Anteros não seja usado na poesia latina, em diversas passagens há alusão aos seus poderes, como na Eneida ${ }^{448}$, em que Dido, depois de ter sido desprezada por Eneias, apela em vão aos poderes divinos para vingar-se desse amor malfadado. Em outras artes é mais difícil distinguir a figura de Anteros, porém já observamos duas obras em que ele pode figurar: a pintura do "Amor Punido" 449 e de "Ariadne Abandonada" $"$.

\section{O paradoxo da paz e da guerra}

Em Roma, a justificativa para a guerra era a tão almejada Pax Romana, o principal mote da política de Augusto. O cenário de servidão e combate, rendições e triunfos, tão familiar aos romanos, é encontrado em grande parte dos poemas, em que Amor frequentemente é figurado comportando-se como o comandante ou membro de um exército e levando suas vítimas a padecerem como cativos de guerra. Guerra e paz são temas indissociáveis não só na política, mas também na poesia augustana, como nesses versos em que Propércio, embora exalte a paz, permanece no âmbito da guerra, ao realizar duro combate com sua amada: Pacis Amor deus est, pacem veneramur amantes:
sat mihi cum domina proelia dura mea. ${ }^{451}$

Amor é o deus da paz; nós, amantes, veneramos a paz:

a mim me bastam os árduos combates com a minha amada.

Nos versos abaixo, de Tibulo, Amor incita uma guerra de natureza lúdica entre os jovens, em que aqueles que perecerem devem ser coroados com guirlandas de murta, a planta de Vênus, parodiando as honrarias dos heróis de guerra:

Ac iuuenum series teneris inmixta puellis

Ludit, et adsidue proelia miscet Amor.

Illic est, cuicumque rapax mors uenit amanti, Et gerit insigni myrtea serta coma. ${ }^{452}$

\footnotetext{
${ }^{447}$ Plat., Fedro 254-255.

${ }^{448}$ Virg. A. 4.520.

${ }^{449}$ Museo Archeologico Nazionale di Napoli, Nápoles, Itália. Amore Punito. Inv. 9257. Pompeia.

${ }^{450}$ Museo Archeologico Nazionale di Napoli, Nápoles, Itália. Arianna Abbandonata. Inv. 9051.

${ }^{451}$ Prop., 3.5.1-2.

452 Tib., $1.3 .63-66$
} 
e uma fila de rapazes, misturada a frágeis moças,

brinca e Amor agita seus embates constantemente.

Lá está todo aquele a quem a Morte ávida atingiu enquanto

amava, e traz na cabeleira distinta coroas de mirto. ${ }^{453}$

Na elegia 1.10, uma recusatio, Tibulo estabelece uma oposição entre pax e bellum: ele lamenta-se dos horrores da guerra e exalta a Paz e a família, com uma invocação aos Lares ${ }^{454}$ para salvá-lo; ele recusa o auxílio de Marte e o furor da guerra dizendo: alius sit fortis in armis. A política augustana incentivava o retorno ao campo, pois muitos nobres haviam perdido seus bens depois da guerra civil. Tibulo, utilizando exempla como argumento de autoridade, introduz a personificação da $\operatorname{Pax}$, em um cenário bucólico, desempenhando atividades da vida rural que equivalem à paz, como colocar os bois no arado, plantar e produzir o vinho. Conte ${ }^{455}$ observa que o tema da paz é fundamental na obra de Tibulo:

Sua oposição ao militarismo e seu repúdio à guerra e seus horrores, o que corresponde a um clamor à paz difundido na cultura da época, após a longa tragédia da guerra civil, encontra ressonância em seu anseio por um mundo ideal, povoado por pessoas humildes e aquecido pelo amor de uma mulher fiel, diametralmente oposto àquele. Por trás das características do idílio bucólico, do qual a influência de Virgílio é notável, o mundo rural de Tibulo revela seu caráter itálico, com sua abundância de valores pertinentes à vida no campo celebrados pela ideologia arcaizante do principado.

Apesar da recusa, Tibulo exalta as guerras no âmbito de Vênus:

Sed Veneris tum bella calent, scissosque capillos

Femina perfractas conqueriturque fores.

Flet teneras subtusa genas, sed victor et ipse

Flet sibi dementes tam valuisse manus.

At lascivus Amor rixae mala verba ministrat, Inter et iratum lentus utrumque sedet.

A, lapis est ferrumque, suam quicumque puellam

Verberat: e caelo deripit ille deos. ${ }^{456}$

Ardem então as guerras de Vênus, e uma mulher se queixa

de seus cabelos arrancados e de suas portas arrombadas;

chora suas tenras faces levemente feridas: mas seu vencedor

também chora por as mãos enlouquecidas terem sido tão pesadas;

mas o lascivo Amor instiga com palavras duras à briga,

e senta-se impassível entre os dois irados.

Ah! É um bloco de pedra, uma barra de ferro, todo aquele que

fere sua amada: ele arranca do céu os deuses. ${ }^{457}$

\footnotetext{
${ }^{453}$ Tradução de J. B. Toledo Prado

454 Tib., 1.10.15-45.

${ }^{455}$ Conte (1999:328).

${ }^{456}$ Tib., 1.10.53-61.

${ }^{457}$ Tradução de J. B. Toledo Prado.
} 
Para Tibulo, as guerras de Vênus associam-se à paz: ele sugere que as mãos cruéis, que pegam em armas, devem afastar-se da deusa. No entanto, Vênus lidera uma guerra que não é tão pacífica: o lascivo Amor posiciona-se entre os amantes e os instiga à discórdia e à troca de insultos, atitude que marca o seu caráter impassível, tranquilo e indiferente, que contrasta-se com a ira e as rixas que ele desencadeia.

Em oposição ao cenário de guerra, Tibulo encerra a elegia 1.10 com uma invocação à $\operatorname{Pax}$ com sua branca túnica transbordando de frutos, uma referência que lembra elementos da figuração do relevo da Ara Pacis:

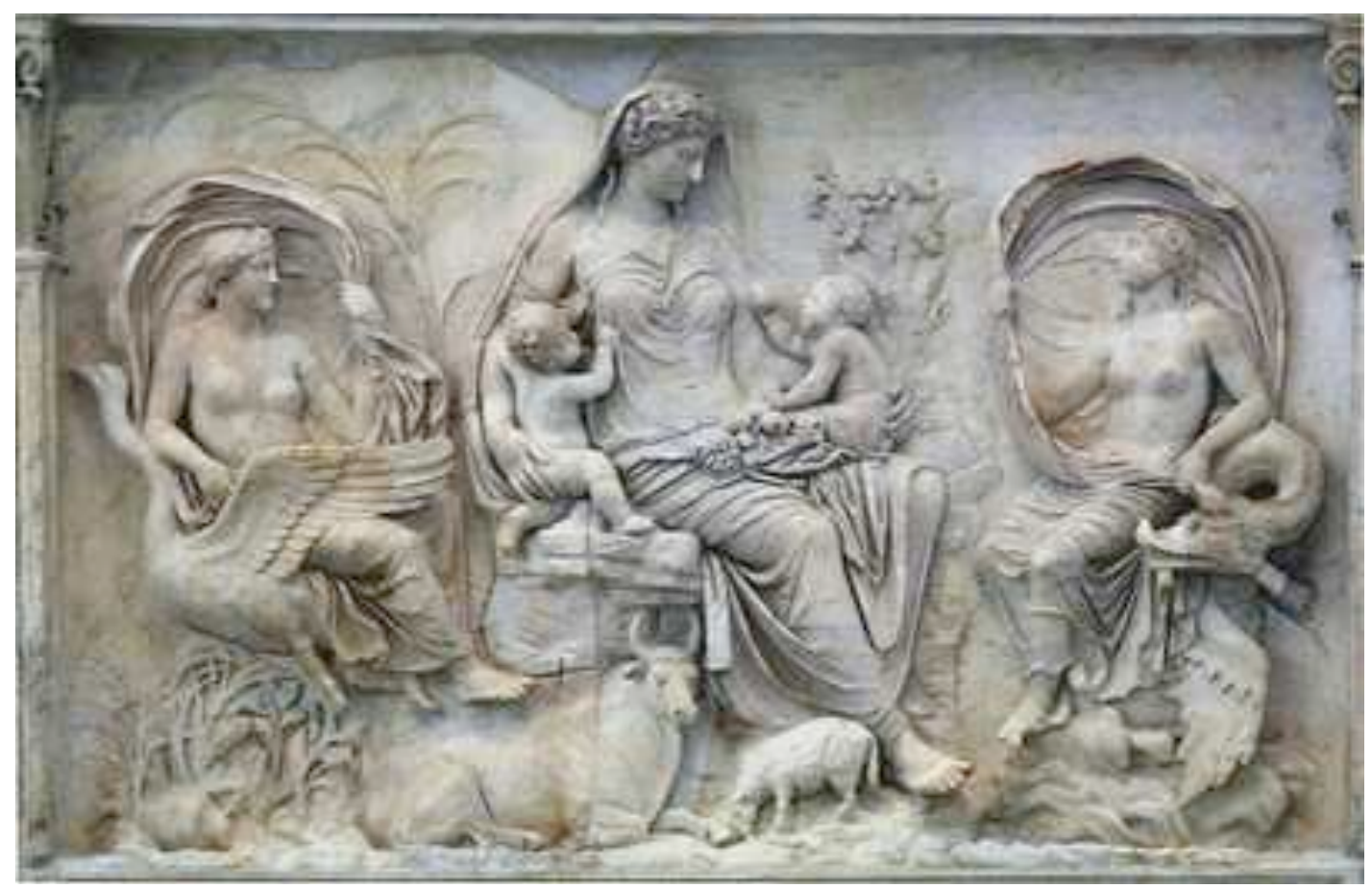

Figura 33. Ara Pacis, Roma

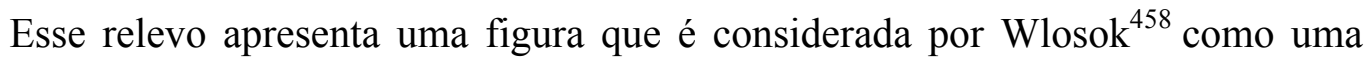
Vênus Genetrix, deusa de seios fartos que indicam seu papel de mãe e nutriz dos meninos. A categorização dessa deusa como Vênus não é consensual. Segundo Kleiner ${ }^{459}$, essa imagem sintetiza diversos elementos de deusas tais como Tellus, Italiae, Vênus, Ília com Rômulo e Remo ou Pax, uma sobreposição de imagens corrente no período augustano. As personificações das brisas sobre a terra e o mar, a profusão de frutos, animais e flores simbolizam fertilidade, crescimento e a prosperidade.

\footnotetext{
${ }^{458}$ Wlosok (1975:171).

${ }^{459}$ Kleiner (1992:96).
} 


\section{Um soldado ferido em seu próprio acampamento}

Em Amores 2.9a, Ovídio tem como interlocutor Amor, ao qual ele lança uma acusação considerada grave pelos romanos, a quebra da fides. Há uma estrutura retórica com argumentos do gênero judiciário nesse poema, que se inicia em discurso exabrupto, como o de Cícero nas Catilinárias ${ }^{460}$, com uma sequência de perguntas que versam sobre a conduta desonrosa de seu adversário ${ }^{461}$, que neste caso é Cupido. Segundo Lausberg ${ }^{462}$, a pergunta retórica, ou interrogatio, com sua veemência, fustiga os afetos. Não se espera uma resposta a esta pergunta, pois ela já é, por si só, uma formulação próxima da exclamatio, que atribui vivacidade à argumentação. $\mathrm{O}$ discurso é de vitupério ao deus: “desidiose Puer!”. O poeta procura argumentos a seu favor ${ }^{463}$ ressaltando sua posição de vítima, já que, como fiel seguidor do estandarte de Amor, sem nunca ter desertado, foi ferido em seu próprio acampamento pelas setas e tocha do menino:

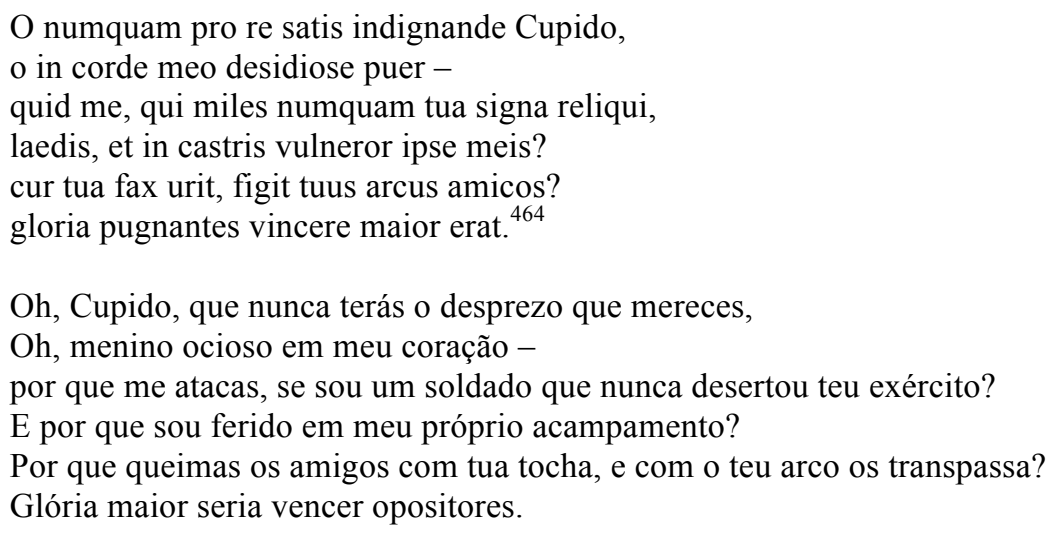

A guerra, o acampamento ${ }^{465}$, o inimigo, a rendição e o peso das armas de Cupido: todo esse vocabulário é adaptado para servir ao contexto ambíguo e paradoxal da militia amoris. A afixação ou a penetração de uma seta, reforçada pela referência ao $\operatorname{arco}^{466}$, sugere a metáfora fálica. A conotação sexual das armas, como discutimos anteriormente, reforça o caráter lúdico que a presença desse deus agrega aos poemas:

nos tua sentimus, populus tibi deditus, arma;

\footnotetext{
${ }^{460}$ Cic., Catil., Oratio Prima.

${ }^{461} \mathrm{Ab}$ adversariorum, cf. Rethorica Ad Herennium, 1.8.13-18.

${ }^{462}$ Lausberg (1967:259).

${ }^{463} \mathrm{Ab}$ nostra personam beneuolentiam, cf. Rethorica Ad Herennium, 1.8.13-18.

${ }^{464}$ Ov., Am. 2.9a.1-7.

465 Pichon (1991:101): “Castra: Amoris fingunt poetae, ubi amantes stipendia faciant”. Tib. 2.3, 34; Ov., Am., $1.2 .32 ; 1.9 .1$ e 44.

${ }^{466}$ Bem (2007:36).
} 
pigra reluctanti cessat in hoste manus.

quid iuvat in nudis hamata retundere tela

ossibus? ossa mihi nuda relinquit amor.

tot sine amore viri, tot sunt sine amore puellae! -

hinc tibi cum magna laude triumphus eat.

Roma, nisi inmensum vires promosset in orbem,

stramineis esset nunc quoque tecta casis. ${ }^{467}$

Nós, povo rendido a ti, sentimos tuas armas;

Sobre o inimigo relutante, tua mão repousa ociosa.

Qual o mérito em abater ossos nus com tuas setas aduncas?

Pois o amor deixou meus ossos à mostra.

Há tantos homens sem um amor, e, sem amores, tantas moças!

Que parta daqui o teu triunfo com grande louvor.

Se Roma não tivesse estendido o seu poder sobre todo o mundo, agora ainda estaria repleta de choupanas.

Apesar do lamento pela injustiça de Cupido, Ovídio exalta e justifica as guerras e vitórias dos romanos, argumentando que elas levam ao merecido descanso como compensação por todo o serviço desempenhado. Do mesmo modo, ele clama para si esses benefícios após os combates com a sua amada:

me quoque, qui totiens merui sub amore puellae, defunctum placide vivere tempus erat.

Eu também, que tantas vezes servi ao amor a uma mulher, tendo cumprido minhas funções, já era tempo de viver placidamente.

\section{A procissão triunfal}

Ovídio inicia Amores 1.2 em tom de lamento, evidenciando o páthos amoroso e os signa amoris causados pela ação do cruel Amor, como o desconforto na cama, inquietação, insônia e ossos revolvidos e doloridos, lembrando o tópos de Eros soltamembros:

Esse quid hoc dicam, quod tam mihi dura videntur strata, neque in lecto pallia nostra sedent, et vacuus somno noctem, quam longa, peregi, lassaque versati corporis ossa dolent? nam, puto, sentirem, siquo temptarer amore. an subit et tecta callidus arte nocet? sic erit; haeserunt tenues in corde sagittae, et possessa ferus pectora versat Amor. Cedimus, an subitum luctando accendimus ignem? cedamus! leve fit, quod bene fertur, onus. ${ }^{468}$

Que diria ser isto: a cama me parecer

Tão dura, e, no leito, não permanecer nossas mantas, $\mathrm{E}$, insone, atravessar a noite, tão longa, E os fatigados ossos do revolvido corpo doem?

\footnotetext{
${ }^{467}$ Ov., Am. 2.9a.11-18.
}

${ }^{468}$ Ov., Am. 1.2.1-11. 
Pois creio que saberia, se fosse provado por algum amor.

Ou ele, engenhoso, se insinua e lesa com um artifício oculto?

Assim será; fixaram-se em meu coração as tênues flechas,

E o feroz Amor revolve o possuído peito.

Cedemos ou lutando avivamos o súbito fogo?

Cedamos! O peso bem conduzido se torna leve. ${ }^{469}$

A caracterização do deus como ferus está ligada ao seu caráter dominador e ao mesmo tempo indomável, com ênfase na sua ação de atirar setas e ferir profundamente, provocando o páthos. Novamente, a construção da persona do deus coincide com a de Eros em epigramas helenísticos, como este:

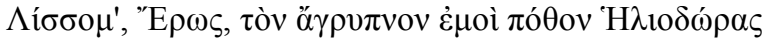

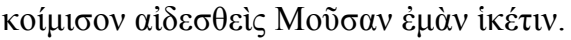

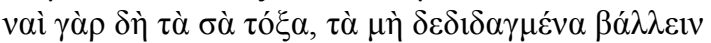

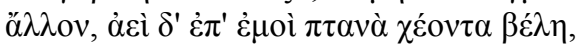

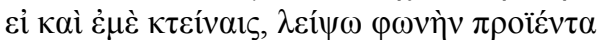

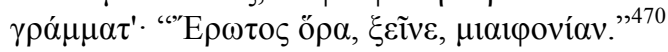 \\ Suplico-te, Eros, adormece o meu desperto desejo por Heliodora \\ em respeito à minha musa suplicante. \\ Sim, juro pelos teus arcos, que não sabem atingir \\ outro e sempre apontam contra mim setas aladas, \\ ainda que me mates, deixarei as letras \\ falantes: "Veja, estranho, a crueldade de Eros."471
}

Em Amores 1.2, após ter sido transpassado por Cupido, Ovídio prefere render-se ao seruitium amoris, argumentando que a resistência torna o fardo ainda mais pesado:

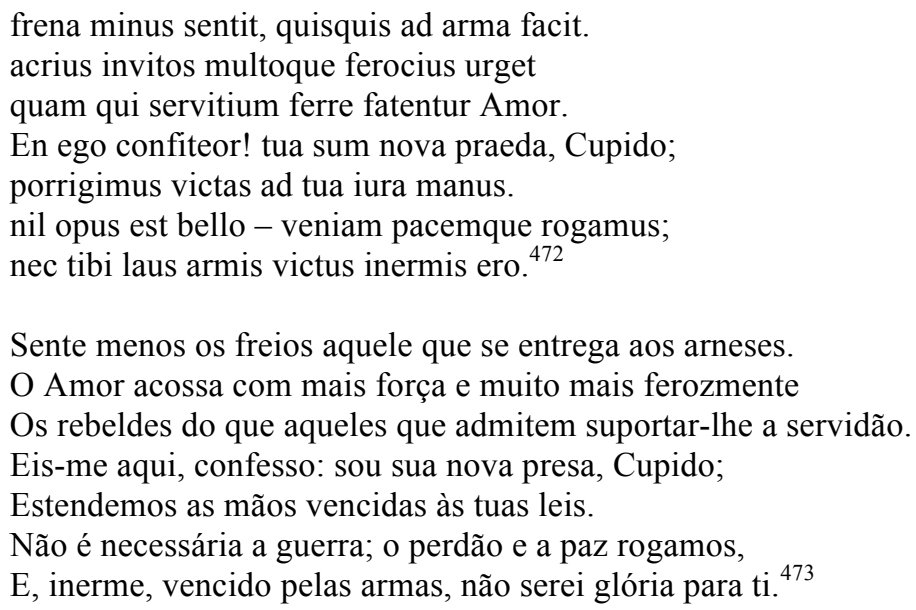

O verbo urgere e os advérbios comparativos acrius e ferocius, definem modo de ação do deus, que urge e domina com veemência e ferocidade, como quem lida com um

\footnotetext{
${ }^{469}$ Tradução de L. A. Bem.

${ }^{470}$ Meleagro, A.P. 5. 215.

471 Tradução F. V. Amaral.

${ }^{472}$ Ov., Am. 1.2.16-22.

${ }^{473}$ Tradução de L. A. Bem.
} 
animal selvagem, tal como bois e cavalos mantidos sob o jugo. Adams ${ }^{474}$ observa, que em Roma, eram comuns metáforas sexuais envolvendo animais como cavalos ${ }^{475}$, sugerindo o ato sexual.

No poema, predominam metáforas que partem do âmbito militar: Amor é capaz de ocultar-se e atacar sorrateiramente as suas vítimas; caracterização que se aplicaria ao êthos de um soldado em guerra. O cenário e o caráter do deus evidenciam uma batalha na qual o poeta encontra-se em plena desvantagem. Ao declarar-se uma nova presa ${ }^{476}$, ele assume a posição de vencido.

Na elegia 1.1 de Propércio, observamos as estratégias e a linguagem corporal de Amor na conquista: o poeta é capturado pelo olhar de Cíntia, e Amor o obriga a abaixar o olhar arrogante, pressionando sua cabeça com os pés ${ }^{477}$, uma atitude violenta comum no embate militar. Álcman ${ }^{478}$ explora esse tópos, com a diferença de que Eros é quem diretamente captura pelo olhar, enquanto no poema de Propércio Amor excerce a captura por intermédio de Cíntia ${ }^{479}$. Se o olhar é fundamental como arma do conquistador, ele também poder ser "espólio de guerra", uma vez que o conquistado perde autonomia sobre seu próprio olhar ${ }^{480}$, que fica entregue aos comandos do deus. Essa mesma violência e tirania na atitude de Eros encontra-se nesse epigrama de Meleagro:

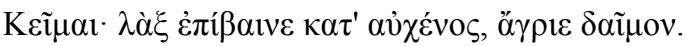

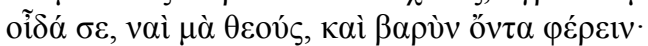

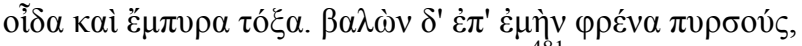

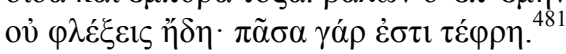

Estou deitado. Coloca o pé no meu pescoço, selvagem divindade. Bem sei que tu, pelos deuses, és fardo pesado. Sei também das setas flamejantes. Mas incendiando o meu coração não me queimarás, pois tudo já está em cinzas. ${ }^{482}$

\footnotetext{
${ }^{474}$ Adams (2002:166).

475 Ov. Rem. 429.

${ }^{476}$ Pichon (1991:238): Praeda: aut quicumque Amori subiectus est. colla premit? Ragusa.

479 Lyne (1974:263).

${ }^{480}$ Mesmo tópos em Prop., 2.30.10; e Ov., Am. 1.2.20.

${ }^{481}$ Meleagro, A.P. 12.48 .

482 Tradução de F. V. Amaral.
}

${ }^{477}$ Prop., 1.1.4: et caput impositis pressit Amor pedibus. Ov., Rem. 530: Et tua saevus Amor sub pede

478 Álcman, frag. 286 Dav.: Eros de novo, sob suas escuras pálpebras, com olhos me fitando derretidamente, com encantos de toda sorte às inextricáveis redes de Cípris me atira. Tradução de G. 
Em Amores 1.2, é dada ênfase à linguagem corporal do cativo, com as mãos estendidas, submisso e entregue às novas leis do conquistador. A moeda abaixo, datada de aproximadamente 49-45 a.C., apresenta dois cativos sob uma estátua ou personificação de um Troféu militar, que estão em posição corporal de submissão, com o tronco inclinado para frente e olhar voltado para o chão; um deles está com as mãos amarradas para trás e o outro apoia com a mão a cabeça inclinada para baixo:
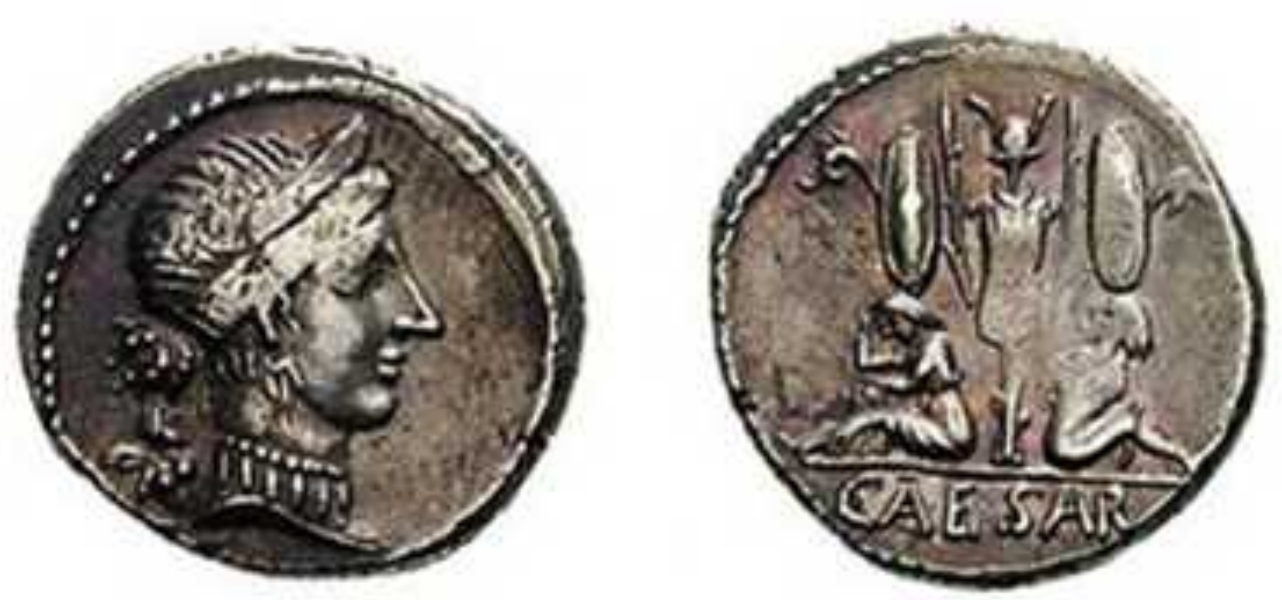

Figura 34. Vênus, Cupido e cativos ${ }^{483}$

A figuração dessa moeda, com presença de Vênus Victrix e Cupido no anverso e dos cativos no reverso, lembra as duas faces da guerra, com os romanos vencedores sob o comando da deusa e seu exército, e os cativos perdedores submetidos ao domínio dos conquistadores $^{484}$. Na elegia de Ovídio, apresentam-se também essas duas faces, e o cenário de servidão e guerra é substituído pela procissão triunfal de Cupido, uma paródia do triunfo romano, com os seus elementos típicos adaptados para o universo amoroso, com toda a pompa do cortejo e o clamor do público:

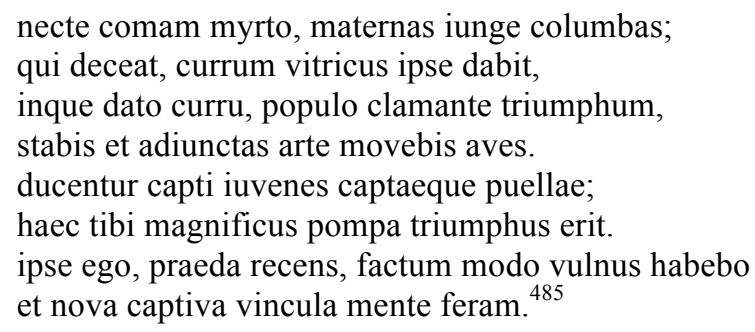

\footnotetext{
${ }^{483}$ Australian Center for Ancient Numismatic Studies, Macquarie University. Roman Coin. 49-45 a.C.. Obverse: Head of Venus right, wearing diadem; behind, Cupid. Border of dots. Reverse: Trophy with oval shield and carnyx in each hand; on left, seated female captive resting head in right had; on right, bearded captive seated with hands tied behind back; in exergue, CAESAR. Border of dots.

${ }^{484}$ Martins (2011:29).

${ }^{485}$ Ov., Am. 1.2.23-30.
} 
Coroa-te com murta, ajunta as pombas maternas;

O carro que te convém teu próprio padrasto dará,

E no carro dado, enquanto o povo aclama o triunfo, estarás em pé

E com maestria guiarás as aves emparelhadas.

Jovens cativos e meninas cativas serão conduzidos.

Este cortejo será teu magnífico triunfo.

Eu mesmo, presa nova, terei a ferida aberta recentemente

E com a mente renovada levarei cativos grilhões.

Os cativos que seguem a procissão são jovens, aludindo à audiência da poesia erótica, e também deuses, como Boa Mente e Pudor. As personificações como Erro e Furor, integrantes da milícia de Cupido, fazem parte do séquito de vitoriosos que acompanha o cortejo:

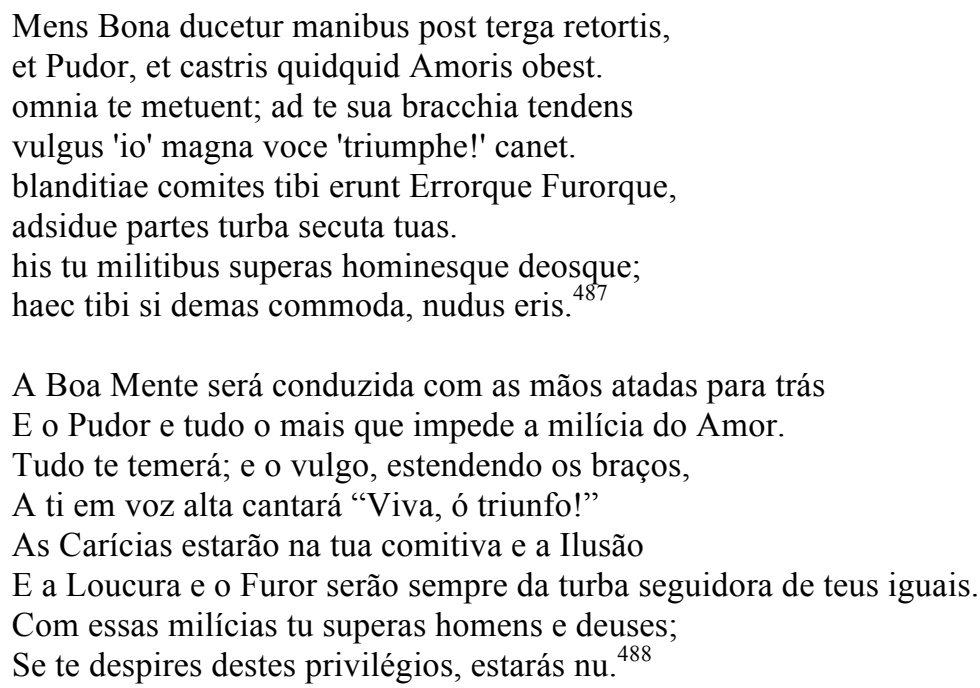

Nesse camafeu romano do século I d.C., dois Amorini erguem uma estátua de Troféu, composta de um elmo e armadura construídos sobre um suporte, aos pés da qual posiciona-se um escudo, figuração que lembra o motivo do triunfo:

\footnotetext{
${ }^{486}$ Tradução de L. A. Bem.

${ }^{487}$ Ov., Am. 1.2.31-38.

${ }^{488}$ Tradução de L. A. Bem.
} 


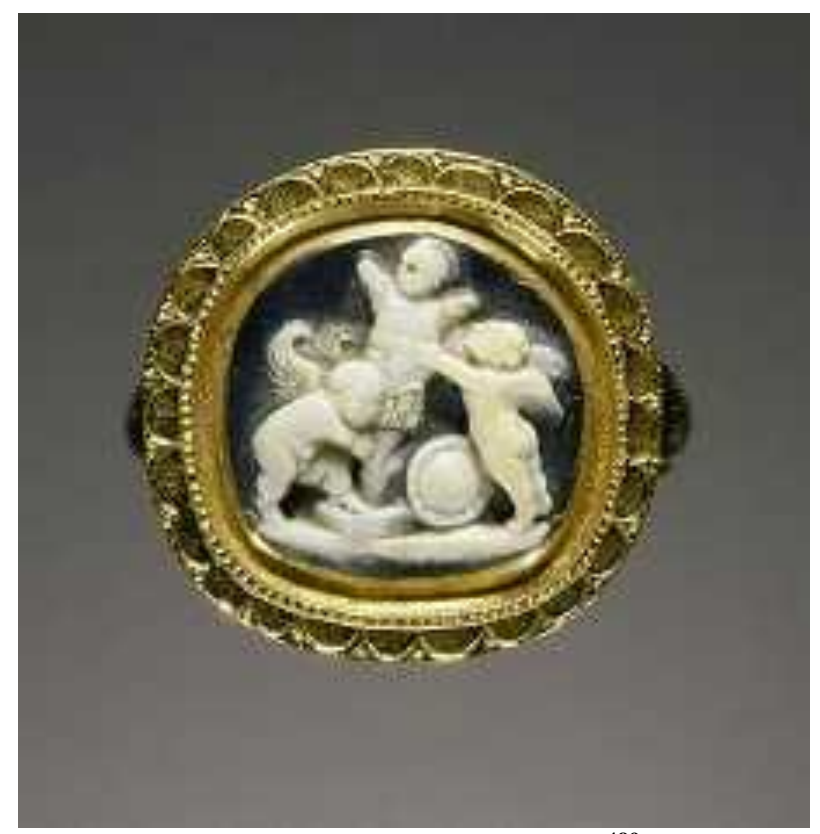

Figure 35. Armas e Cupidos ${ }^{489}$

$\mathrm{Na}$ elegia triunfal de Ovídio, em chave de epidítica, Cupido aparece recebendo as mais altas honrarias. Do alto do Olimpo, a mãe esparge rosas em sua face triunfante. Áureo ${ }^{490}$, adornado com gemas nos cabelos e nas asas, ele desfila em sua carruagem de ouro. Ele é coroado com a murta, a planta símbolo de Vênus, em vez dos tradicionais louros da vitória, e assume posição central no cortejo como um César:

Laeta triumphanti de summo mater Olympo plaudet et adpositas sparget in ora rosas. tu pinnas gemma, gemma variante capillos ibis in auratis aureus ipse rotis. ${ }^{491}$

A mãe, feliz, do cimo do Olimpo ao triunfante Aplaudirá e espargirá ao teu rosto as rosas já consagradas.

$\mathrm{Tu}$, enfeitado nas asas com gemas, com gemas nos cabelos enfeitado, Tu mesmo, áureo, sobre áureas rodas irás. ${ }^{492}$

A luminosidade dourada do deus e de sua carruagem, o brilho das gemas nas asas e nos cabelos produzem o efeito vivificante que Quintiliano chama de enargia:

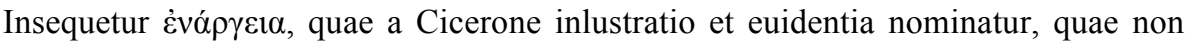
tam dicere uidetur quam ostendere, et adfectus non aliter quam si rebus ipsis intersimus sequentur. An non ex his uisionibus. ${ }^{493}$

\footnotetext{
${ }^{489}$ The Getty Museum, Malibu. Roman gem, 1-100 A.D.; Modern ring. Onyx and gold; cameo mounted in a modern ring. The gold ring into which this cameo is set is modern.

${ }^{490}$ Pichon (1991:92): Aureus dicitur Amor ... quibus in exemplis nihil est aureus nisi uox summae admirationis. Ov., Am. 2.18.36.

${ }^{491}$ Ov., Am. 1.2.39-42.

492 Tradução de Lucy Ana de Bem.

${ }^{493}$ Quint., Inst. Or., 6.2.32.
} 
Segue-se a enargia, que é chamada por Cícero de illustratio ou evidência, que parece não tanto dizer, mas mostrar; e, não de outro modo, os afetos se seguirão, como se estivéssemos presentes nos próprios acontecimentos. ${ }^{494}$

Desse modo, Ovídio pões diante de nossos olhos a imagem reluzente de Cupido, como se estivéssemos presentes à cena do triunfo.

O triundo de Amor é comparado ao de Baco em um símile que evidencia a imagem do deus em sua carruagem na procissão triunfal; substituindo-se, no entanto, os tigres de Baco pelas pombas de Vênus:
tunc quoque non paucos, si te bene novimus, ures;
tunc quoque praeteriens vulnera multa dabis.
non possunt, licet ipse velis, cessare sagittae;
fervida vicino flamma vapore nocet.
talis erat domita Bacchus Gangetide terra;
tu gravis alitibus, tigribus ille fuit. ${ }^{495}$
Então também não a poucos abrasarás, se bem te conhecemos, Então também, avante, causarás muitas chagas;
As setas não podem cessar, ainda que tu mesmo o queiras;
A férvida chama prejudica aos próximos com o seu vapor.
Tal era Baco, dominada a terra Gangétide:
Tu, imponente com aves; ele, com tigres. ${ }^{496}$

Imagens de Cupidos conduzindo bigas são comuns na pintura, nessa abaixo, como no poema, ela é conduzida por aves:

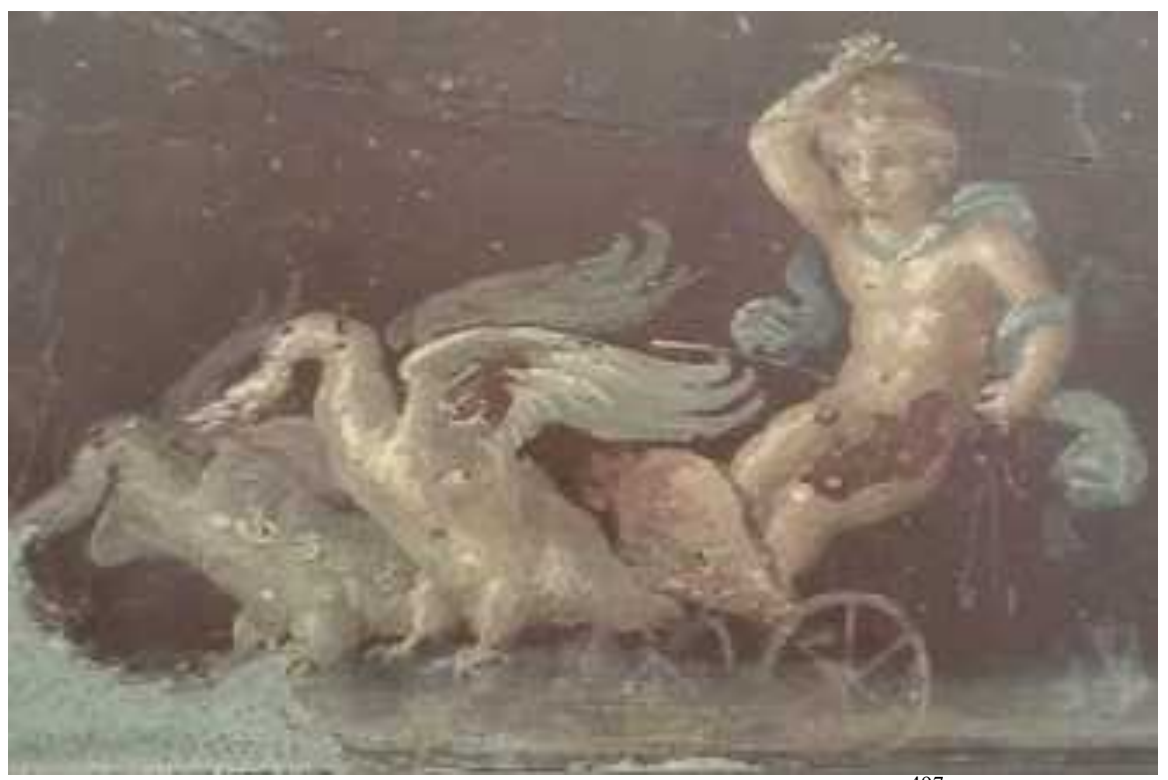

Figura 36. Erote em biga conduzida por cisnes ${ }^{497}$

\footnotetext{
${ }^{494}$ Tradução de M. Rodolpho.

${ }^{495}$ Ov., Am. 1.2.43-48.

${ }^{496}$ Tradução de L. A. Bem.
} 
Ovídio sugere que Cupido, como filho de Vênus, apresenta um parentesco com César, via gens Iulia, e o discurso em seu louvor reverbera por toda sua linhagem ${ }^{498}$. O poeta clama pela misericórdia do deus, cujas setas não cessam de atingí-lo, causando a ferida $^{499}$ que arde em chamas. César, por sua vez, é mencionado como o protetor dos vencidos, traço que revela a sua superioridade, diametralmente oposta à do impiedoso Amor, configurando uma inversão hierárquica entre homens e deuses. Ovídio sugere ao deus que comporte-se como César, que estende a mão aos cativos:

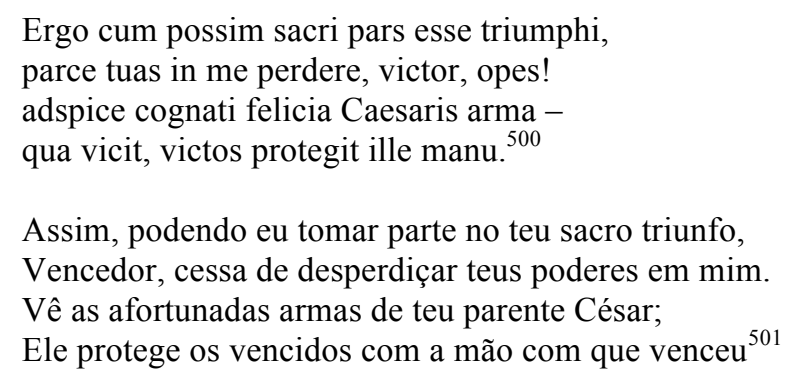

Tal discurso soa como se tal parentesco fosse um privilégio para Cupido, que é um deus.

Na escultura abaixo, conhecida como Augusto da Prima Porta, o deus montado em um golfinho aos pés de Augusto lembra o parentesco divino e as vitórias militares dos Césares. Para Kleiner ${ }^{502}$, a presença de Cupido montado em um golfinho nessa estátua é uma alusão à Batalha de Ácio. Já discutimos a figuração de Cupido com golfinhos anteriormente, e segundo o levantamento que fiz, ela pode ser encontrada ao menos desde o século III a.C. na Grécia ${ }^{503}$. Porém, não excluo a possibilidade levantada por Kleiner, pois novas metáforas tendem a acumular-se sobre uma mesma figuração, incluindo-se nesta, possivelmente, não só a referência à batalha naval, mas à ascendência divina da gens Iulia:

\footnotetext{
${ }^{497}$ Museo Archeologico Nazionale di Napoli, Napoli, Itália. Inv. 9173. Amorino su carro. Pompei. Alt. cm. 26; largh. cm. 42. 62-79 d.C..

${ }^{498}$ Martins (2010:29); Bem (2007:112).

${ }^{499}$ Pichon (1991:302): "Vulnera: multo saepius uulnera sunt Amoris ictu. Prop., 2.22.7; 2.25.46; 3.11.6; 4.4.30.

${ }^{500}$ Ov., Am. 1.2.49-52.

501 Tradução de L. A. Bem.

${ }^{502}$ Kleiner (1992:114).

${ }^{503}$ Cf., MFA Boston, espelho de bronze com Éros montado em um golfinho. Acc. Number: 98.671a.
} 


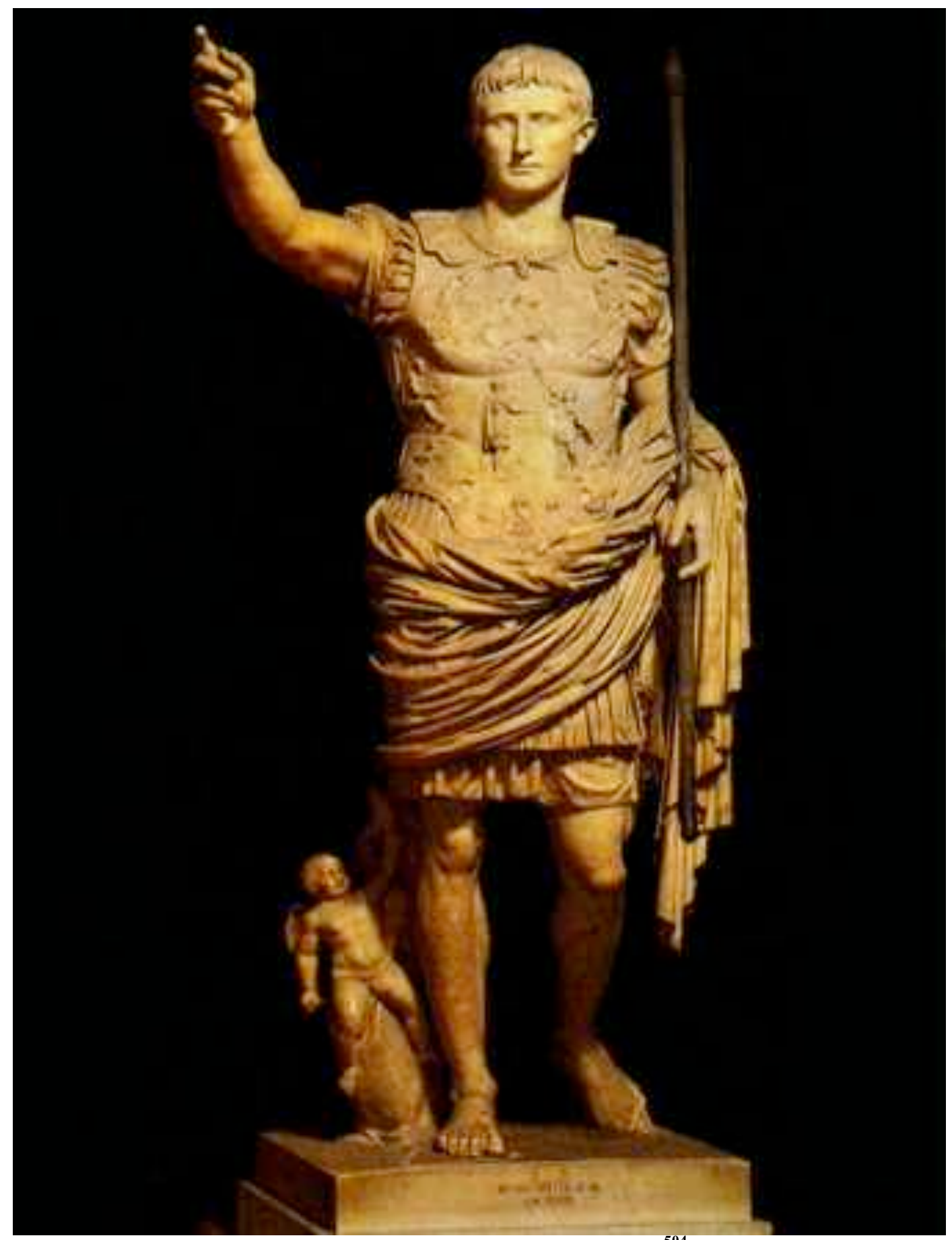

Figura 37. Augusto de Prima Porta 504

\footnotetext{
${ }^{504}$ Museu do Vaticano. The Augustus of Prima Porta, believed to have been commissioned in 15 A.D. by Augustus' adopted son Tiberius, is a majestic example of Imperial Roman statuary. It is currently under restoration, generously financed by the patrons of the Florida chapter. It was discovered at Prima Porta nine miles outside of Rome in the villa belonging to Augustus' wife Livia. Although it may be a copy of a bronze original, dated 20 B.C., Tiberius made a significant addition to his marble copy: on the chest plate, he added scenes depicting the Roman victory over the Parthians. These scenes were used by Tiberius as a form of propaganda so that the viewer would recall the important role his father played in securing the Roman empire.
} 


\section{Seruitium Amoris}

Depois do triunfo dos vencedores segue-se a escravidão do cativo; assim, a militia amoris é indissociável da tópica seruitium amoris. Copley ${ }^{505}$ observa que a escravidão amorosa é uma ideia constante na mente dos elegistas, e que, com eles, o seruitium amoris torna-se praticamente um sinônimo de amor. Como vimos em exemplos anteriores, Cupido assume personae que assemelham-se a personagens do âmbito militar: ele é caracterizado como guardião ${ }^{506}$, ou general de um exército com seu próprio acampamento ${ }^{507}$ e estandarte ${ }^{508}$. Seu comportamento é autoritário e rígido em conformidade com as atividades que desempenha. Nas elegias augustanas há uma vasto repertório que remete à dominação e à servidão. As ações atribuídas ao deus revelam o caráter impositivo e dominador: cogere ${ }^{509}$, regnare ${ }^{510}$, iubere ${ }^{511}$,

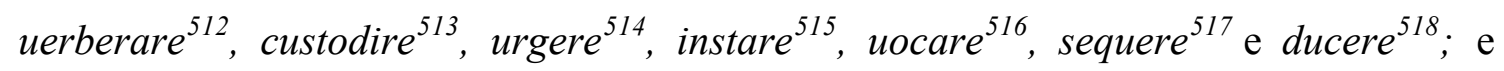
algumas de suas características anímicas confirmam sua tirania e ferocidade: ferus $^{519}$, saeuus $^{520}$, durus $^{521}$, aduersus ${ }^{522}$, iniquus ${ }^{523}$, acer ${ }^{524}$, ambitiosus ${ }^{525}$, potens ${ }^{526}$ e turpis $^{527}$.

Adams $^{528}$ lembra que palavras do campo semântico que envolve a ideia de "serviço ou cumprimento de obrigações", como seruio e officium, são frequentemente usadas como metáfora para diferentes formas de atividade sexual: Platão, no

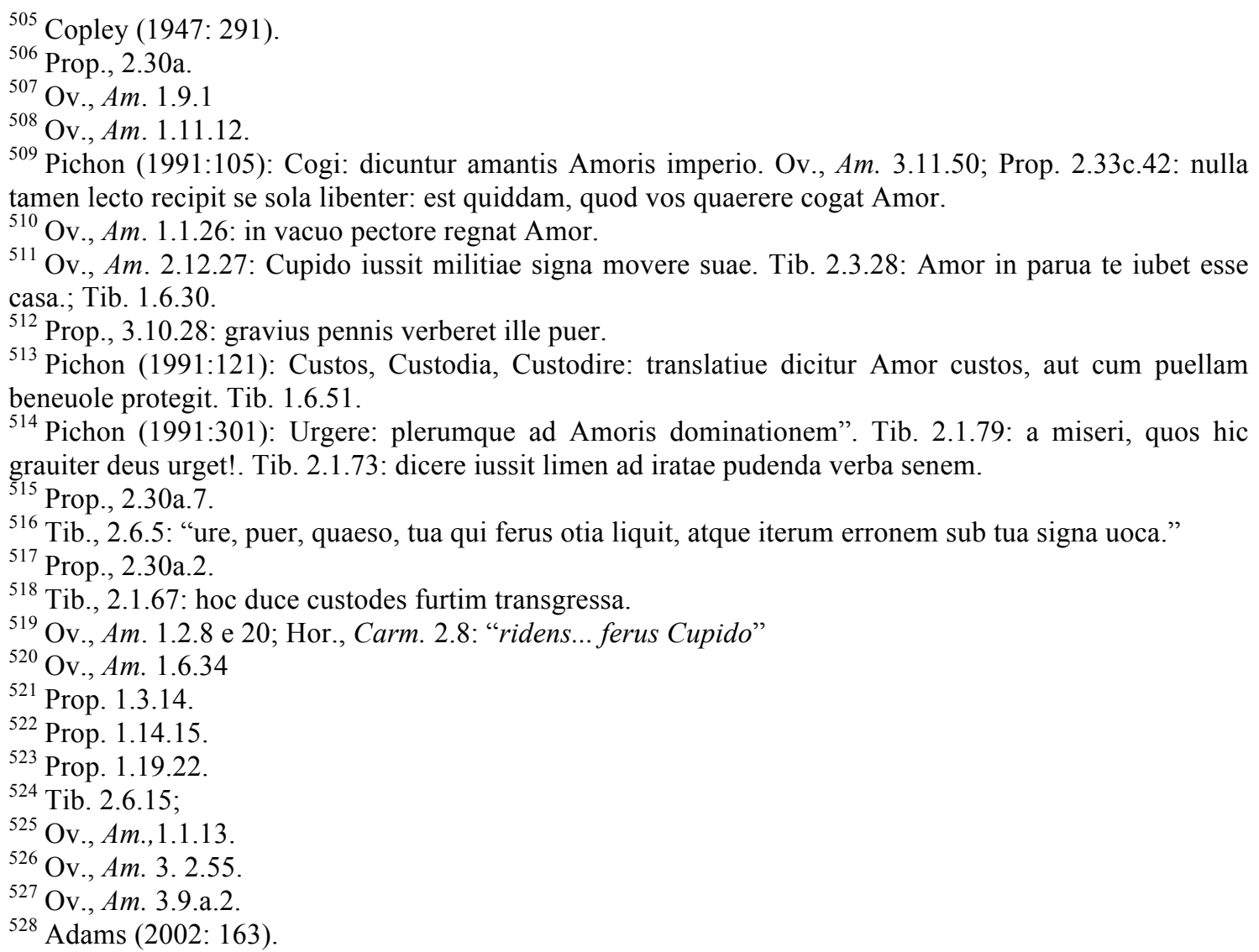


Simpósio ${ }^{529}$, por exemplo, refere-se ao serviço prestado pelo jovem em relações homossexuais; em Roma, o verbo seruio pode referir-se à patientia homossexual ${ }^{530}$, e o termo officium, ao sexo passivo oferecido por homens ou mulheres ${ }^{531}$. Em elegias romanas, ironicamente, em geral a mulher é dominante, e, ao homem, cabe servi-la.

Copley ${ }^{532}$ observa que nos exempla míticos que aparecem em elegias augustanas, até mesmo os deuses fazem o papel de escravos de Amor. Tibulo, na elegia 2.3, compara a sua situação de subserviência com o mito de Apolo e Admeto, um dos principais exempla associados ao seruitium amoris. Ao ser vencido por Amor, Apolo é humilhado, passando a desempenhar tarefas típicas de camponeses, que não condizem com sua elevação. Esses argumentos sugerem que o amante deve submeter-se ao seruitium amoris por vontade própria, comprazendo-se com sua posição de submissão.

\section{Amor como custos}

$\mathrm{Na}$ concisa elegia 2.30a, de apenas 12 versos, Propércio dá várias indicações dos mecanismos de dominação de Amor no papel de custos:

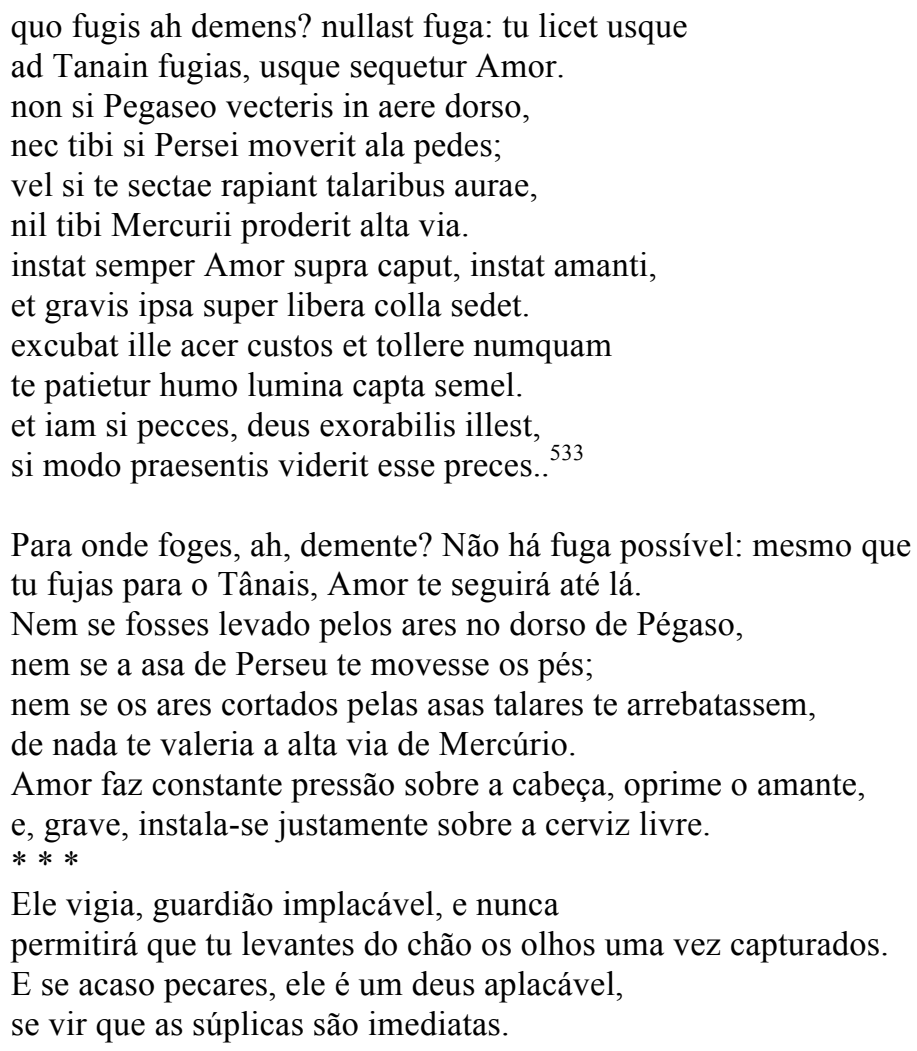

\footnotetext{
${ }^{529}$ Platão, Symp. 184d.

${ }^{530}$ Cic., Cat. 2.8; Phil. 2.86.

${ }^{531}$ Ov., Am. 3

${ }^{532}$ Copley (1947:288-289).

${ }^{533}$ Prop., 2.30a.
} 
Mencionamos anteriormente a figura do custos, o guardião, cuja ação principal é indicada pelo verbo excubare, que significa montar guarda, vigiar. Este termo pertence ao repertório militar e pode ser encontrado em frases como esta do De Bello Gallico: duae semper legiones pro castris excubabant ${ }^{534}$ (duas legiões sempre montavam guarda diante do acampamento).

É grande o debate sobre quem seria o interlocutor de Propércio nessa elegia que tem como temas a tentava frustrada de recusa do amor e o seruitium amoris, evidenciando a impossibilidade de fuga e a humilhação. Segundo Cairns ${ }^{535}$, ela pode ser endereçada a Cíntia, a quem o poeta tenta persuadir a não abandoná-lo; por outro lado, tendo a achar mais plausível a sugestão de Fedeli, que diz que tal destinatário pode ser um amigo, pois na elegia romana é o homem normalmente vítima da perseguição de Amor, e não a mulher, a quem cabe o papel de algoz.

O poema inicia-se em discurso direto com a interrogatio: Quo fugis a demens?. A palavra demens refere-se ao estado de insânia, loucura e alienação, típico dos que estão sob a ação de Cupido. Amor é um guardião zeloso, do qual é inútil fugir, pois ele sempre alcançará o amante para onde quer que vá. Propércio lança mão de exempla míticos, a fim de amplificar essa ideia: nem mesmo os atributos dos seres mais velozes, que podem voar, como o cavalo Pégaso, Perseu e Mercúrio, ajudariam na fuga.

A partir do verso 7, estabelece-se um cenário no qual figuram os amantes e Amor, pairando sobre suas cabeças: instat semper Amor supra caput, instat amanti. O verbo instare ${ }^{536}$ evidencia a posição de domínio do deus; e o verso: et grauis ipse super libera colla sedet, reforça as referências espaciais, especialmente o posicionamento sobre o pescoço do amante. Na figuração do vaso abaixo, Cupido igualmente posicionase acima dos amantes, iconizando a relação sexual:

\footnotetext{
${ }^{534}$ Caes. B. G. 7.24 .

${ }^{535}$ Cairns (1971:205).

${ }^{536}$ Pichon (1991:173): Instare: dicitur Amor iis quos imperio suo subiectos habet.
} 


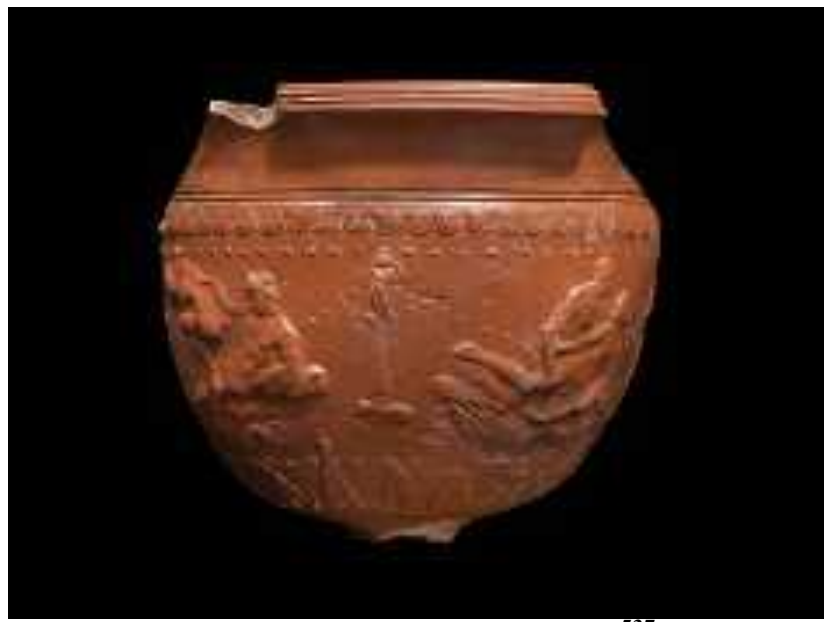

Figura 38. Cerâmica Arretina ${ }^{537}$

Tibulo utiliza a figuração de Amor como custos ao mencionar a punição imputada àqueles que tentam atentar contra sua protegida:

Parcite, quam custodit Amor, uiolare puellam,

Ne pigeat magno post didicisse malo.

Adtigerit, labentur opes, ut uolnere nostro

Sanguis, ut hic uentis diripiturque cinis. ${ }^{538}$

Deixai de atentar contra a donzela que Amor protege, para que depois não vos arrependais de ter aprendido com um grande mal: se a tocardes, vossos bens escaparão pelos dedos, como o sangue de nossas feridas, como estas cinzas se dissipam aos ventos. ${ }^{539}$

Uma das mais antigas referências à caracterização de Eros como o vigia que aprisiona encontra-se em versos de Í́bico ${ }^{540}$, em que, segundo Ragusa ${ }^{541}$, Bóreas é plasmado na figura de Eros, trazendo a tempestade que aprisiona os sentidos. Posteriormente Meleagro também utilizou essa metáfora:

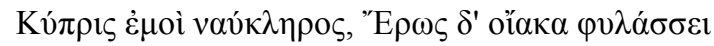

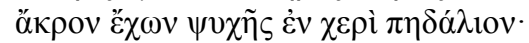

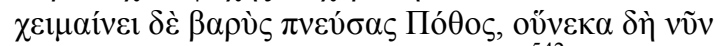

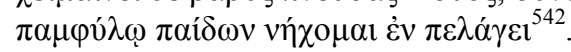

Cípris é minha capitã, e Eros vigia o timão, tendo na mão a empunhadura de meu ânimo;

\footnotetext{
${ }^{537}$ MFA, Boston. Accession number: 13.109. Fragmentary bowl with Cupid on a column between couples making love. Roman, Augustan period, late 1st century B.C. Place of Manufacture: Arretium (modern Arezzo), Tuscany, Italy. Height x diameter: 14 x $10.6 \mathrm{~cm}$ (5 1/2 x 4 3/16 in.). Ceramic, Arretine ware. Classification: Vessels. Catalogue: Arretine Pottery (MFA), no. 053. Two coitus groups. Between them, Eros on a pillar. Thirteen fragments joined together. Foot missing.

${ }^{538}$ Tib., 1.6.51-54.

539 Tradução de J. B. Toledo Prado.

540 Íbico, fr. 286 Dav. 9-13. “... mas, para mim, a paixão não repousa em nenhuma estação. $+\mathrm{E}+$, com raios marcando o caminho, o trácio Bóreas, voando veloz da casa de Cípris com crestantes loucuras, sombrio, descarado, com mão firme, desde o fundo, +vigia+ meus sensos... Tradução de Giuliana Ragusa (2010:395).

541 Sobre a figuração de Éros como vigia ou carcereiro na poesia grega, cf. Ragusa (2010:412-415).

${ }^{542}$ Meleagro, A.P. 12.157.
} 
e o pesado Potos, Desejo, soprando, traz a tempestade, porque agora nado no pélago fervilhante de meninos. ${ }^{543}$

\title{
Sob o jugo de Amor
}

Os principais instrumentos utilizados por Cupido para o escravizar suas vítimas são o laço ${ }^{544}$ e as correntes $^{545}$. Nesta elegia de Tibulo, Amor aprisiona o poeta submetendo-o à escravidão por uma mulher:

\author{
Sic mihi servitium video dominamque paratam: \\ Iam mihi, libertas illa paterna, vale, \\ Servitium sed triste datur, teneorque catenis, \\ Et numquam misero vincla remittit Amor, \\ Et seu quid merui seu quid peccavimus, urit. \\ Uror, io, remove, saeva puella, faces. \\ $\mathrm{O}$ ego ne possim tales sentire dolores, \\ Quam mallem in gelidis montibus esse lapis, \\ Stare vel insanis cautes obnoxia ventis, \\ Naufraga quam vasti tunderet unda maris! $!^{546}$ \\ Sim, vejo que me foram preparadas a escravidão e uma senhora: \\ já para mim, antiga liberdade de meus pais, adeus; \\ mas uma dura escravidão é decretada, sou mantido em correntes, \\ e Amor nunca afrouxa os grilhões a este infeliz, \\ e, ou porque mereci ou porque errei, ele me queima; \\ estou ardendo, ah! Retira, cruel donzela, os archotes. \\ Ah, se eu pudesse não sentir tais dores, \\ como preferiria nos enregelados montes ser pedra, \\ ou firme rocha exposta aos furiosos ventos, \\ que a tempestuosa onda do mar vítreo açoitasse! $!^{547}$
}

Tibulo estabelece um cenário para essa servidão amorosa, em que não consegue libertar-se da dominação do deus. A tocha ${ }^{548}$, outra arma de Cupido, nessa elegia aparece nas mãos da puella, uma transposição de atributos do deus que, como já foi discutido anteriormente, é comum na poesia latina. O verbo urere, queimar, aparece na voz ativa e na passiva: urit (5) e uror (6), especificando o agente e o receptor da ação de queimar, e assim dando ênfase à invertida relação de algoz versus vítima: a puella

\footnotetext{
543 Tradução de Giuliana Ragusa (2010:413).

${ }^{544}$ Ov., Am. 1.2.30 e Prop., 2.15.25-6.

${ }^{545}$ Pichon (1991:102): Catena: modo in deteriorem partem accipitur, et durum amantium seruitium significat.

546 Tib., 2.4.1-10

547 Tradução de J. B. Toledo Prado.

${ }^{548}$ Pichon (1991:144): Fax: Alias hoc uerbo significatur ignis amoris a puella concitatus, etiamsi deus Amor non nominetur. Prop. 1.13.26; 2.3.14; 2.8.8.
} 
contra o amante elegíaco. O poeta responsabiliza Vênus por sua participação no que ele chama de crime $^{549}$ :

Sed Venus ante alios est violanda mihi.

Illa malum facinus suadet dominamque rapacem

Dat mihi: sacrilegas sentiat illa manus. ${ }^{550}$

é Vênus, porém, antes de todos, quem devo profanar: ela me induz a um crime odioso e uma amante rapace me dá; ela que sinta minhas mãos sacrílegas. ${ }^{551}$

Os versos abaixo aludem ao topos de Eros doce-amargo na persona da amada, cuja beleza se contrasta com outros males que ela provoca, como choro e brigas:

\author{
Heu quicumque dedit formam caelestis avarae, \\ Quale bonum multis adtulit ille malis! \\ Hinc fletus rixaeque sonant, haec denique causa \\ Fecit ut infamis hic deus esset Amor. ${ }^{552}$ \\ Ah! Seja qual for o deus que concedeu a beleza à avara, \\ que bem ele trouxe junto com tantos males! \\ Desde então, soam o choro e as brigas, esta é por fim a razão \\ que fez com que Amor pareça hoje um deus desacreditado. ${ }^{553}$
}

Em suma, Amor exerce sua tirania com toda violência de um soldado em guerra. Para exercer sua dominação, ele conta com sua protegida, que assimila alguns de seu principais atributos, como a beleza, o poder sedutor do olhar, entre outros que já mencionamos.

\title{
Omnia uincit Amor
}

Como vimos anteriormente, o amor é uma força (uis), um poder que a tudo supera. Em sua forma personificada, ele domina com extrema veemência e violência, dilacerando suas vítimas; ele é um guerreiro ou sentinela, sempre em guarda, de quem é impossível escapar. Os versos de Virgílio nas Bucólicas sintetizam essa ideia: omnia uincit Amor: et nos cedamus Amori. ${ }^{554}$ (Amor a tudo supera: e nós, cedamos a Amor!). Sabemos que essa força, apesar de opressora, também direciona os passos do amante para o seu objeto de desejo, desde que em conformidade com a vontade do deus. Esse aspecto pode ser observado em Amores 1.6, em que a principal tópica é a do

\footnotetext{
${ }^{549}$ Crimen amoris, cf. Prop. $2.30 \mathrm{~b}$.

${ }^{550}$ Tib., 2.4.24-27.

551 Tradução de J. B. Toledo Prado.

552 Tib., 2.4.35-38.

${ }^{553}$ Tradução de J. B. Toledo Prado.

${ }^{554}$ Virg., Ecl. 10.69.
} 
paraklausithyron. Amor assume a persona do custos que conduz o poeta até as portas da amada. O poeta, na persona do exclusus amator, suplica ao porteiro (ianitor) para que abra as portas da casa, a fim de que ele possa consumar o amor. Ele é barrado, e tenta persuadi-lo a abrir, elencando argumentos entre os quais alega ter emagrecido por causa do amor, condição que o tornou apto para atravessar pelo vão da porta:

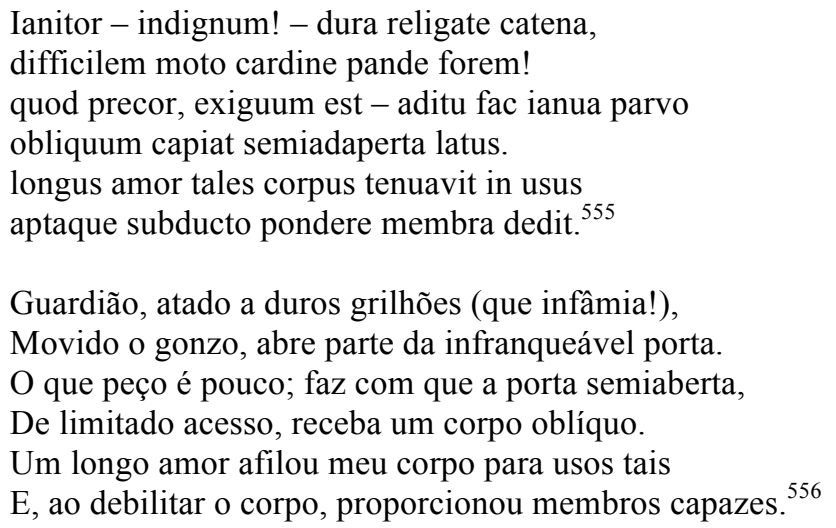

A porta (ianua, foris) que o amator implora para atravessar pode também ser interpretada como uma metáfora sexual. Segundo Adams ${ }^{557}$, a porta normalmente é metáfora para o orifício pelo qual entra o órgão sexual ${ }^{558}$, seja no corpo feminino ou $\operatorname{masculino}^{559}$.

Tibulo, nesta elegia, favorecido por Amor, tem o caminho aberto para atravessar as portas e assim experimentar os prazeres de Vênus:

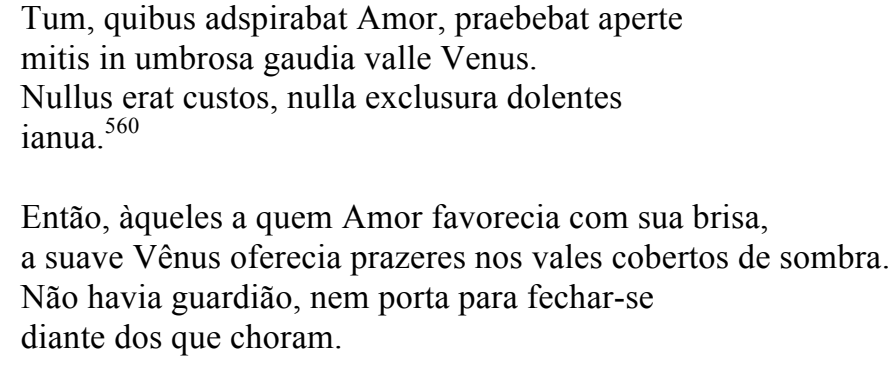

Em Amores 1.6, o poeta dirige ao deus um discurso de louvor que soa como um hino em exaltação aos seus dons e atributos, ressaltando principalmente a coragem, ao dizer que foi ele quem o ensinou a caminhar furtivamente e o livrou do medo. No

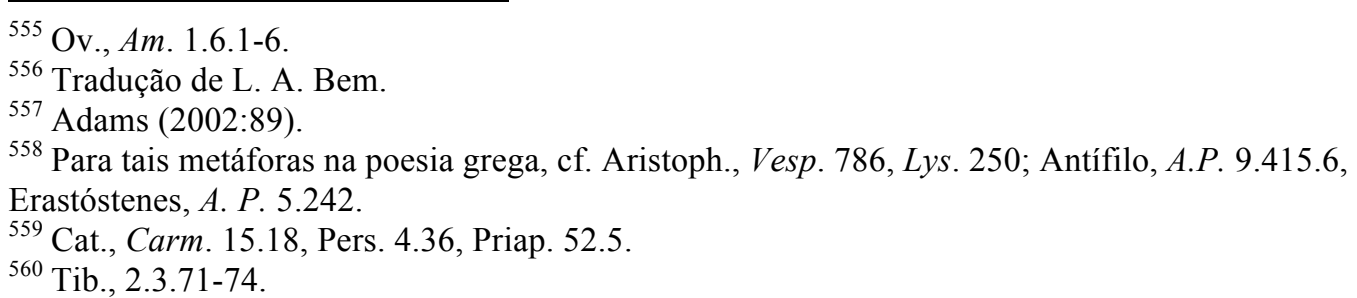


entanto, o poeta diz temer mais que tudo o próprio deus que o beneficia, cujo poder equipara-se ao de Júpiter, com o atributo do raio, que simboliza a supremacia e o poder de aniquilação:

\author{
At quondam noctem simulacraque vana timebam; \\ mirabar, tenebris quisquis iturus erat. \\ risit, ut audirem, tenera cum matre Cupido \\ et leviter 'fies tu quoque fortis' ait. \\ nec mora, venit amor - non umbras nocte volantis, \\ non timeo strictas in mea fata manus. \\ te nimium lentum timeo, tibi blandior uni; \\ tu, me quo possis perdere, fulmen habes. ${ }^{561}$ \\ Ele, em meio às sentinelas de guardas silenciosos \\ Ensina ir, ele dirige os meus pés livres. \\ Mas outrora eu temia a noite e vãos espectros; \\ Admirava qualquer um que fosse andar pelas sombras. \\ Cupido riu, para que eu ouvisse, com sua terna mãe, \\ E brandamente disse "tu também te tornarás valente". \\ Sem demora veio o Amor; nem sombras volantes na noite, \\ Nem mãos voltadas contra meus fados temo; \\ Temo-te, demasiado insensível, lisonjeio só a ti; \\ Tu tens o raio com o qual podes fulminar-me. ${ }^{562}$
}

A imagem de Cupido com um raio não é comum na poesia latina, e parece sugerir uma transposição ou assimilação dos atributos de Júpiter. Há uma passagem de História Natural em que Plínio menciona a existência de uma estátua de Cupido com este atributo, uma obra que se inclui entre as várias que ele lista como de autoria desconhecida:

similiter in curia Octaviae quaeritur de Cupidine fulmen tenente; id demum adfirmatur, Alcibiaden esse, principem forma in ea aetate. ${ }^{563}$

Igualmente, há controvérsia sobre um Cupido segurando um raio na cúria de Otávia; o que precisamente se afirma é que possuía a aparência Alcebíades, o mais belo daquela época.

Depois de exaltar o poder do deus que o acompanha e a coragem por ele concedida, o poeta passa a ironizar sua própria condição, utilizando metáforas militares adaptadas ao universo do simpósio, em que ele afirma não possuir milícia armada, mas apenas a companhia de Amor e uma coroa desajeitada sobre os cabelos úmidos:

Non ego militibus venio comitatus et armis; solus eram, si non saevus adesset Amor.

hunc ego, si cupiam, nusquam dimittere possum;

\footnotetext{
${ }^{561}$ Ov., Am. 1.6.9-16.

${ }^{562}$ Tradução de L. A. Bem.

${ }^{563}$ Pl., Nat. 36.29.1.
} 
ante vel a membris dividar ipse meis.

ergo Amor et modicum circa mea tempora vinum mecum est et madidis lapsa corona comis.

arma quis haec timeat? quis non eat obvius illis ${ }^{564}$

Eu não venho acompanhado de uma milícia armada;

Estaria só, se o sevo Amor não me acompanhasse;

Eu, ainda que o desejasse, não posso mandá-lo a parte alguma;

Antes disso eu mesmo estaria apartado de meus membros,

Assim o Amor e um delgado vime ao redor de minhas têmporas

E uma coroa caída de meus cabelos úmidos comigo estão. ${ }^{565}$

$\mathrm{O}$ cruel $^{566}$ Amor subjuga seu corpo e mente, posicionando-se junto a ele de maneira tenaz e irresistível. Ele age sobre sua cabeça, e, com a ajuda de outras personificações como Líber e Noite, quita sua capacidade de raciocínio e entendimento:

\begin{abstract}
Aut ego iam ferroque ignique paratior ipse, quem face sustineo, tecta superba petam. nox et Amor vinumque nihil moderabile suadent; illa pudore vacat, Liber Amorque metu. omnia consumpsi, nec te precibusque minisque movimus, o foribus durior ipse tuis. ${ }^{567}$

As horas da noite se vão; arranca o ferrolho à porta, Ou eu mesmo, já mais preparado, com o ferro e o fogo Que na tocha sustenho, atacarei o soberbo teto.

A Noite e o Amor e o vinho a nada de sensato me exortam; Ela está livre de pudores, Líbero e Amor, de medos. Esgotaram-se todos os recursos, nem por súplicas e ameaças Te comovemos, tu, mais duro que tuas portas. ${ }^{568}$
\end{abstract}

O mosaico romano abaixo, datado do século I a.C., apresenta um leão cercado de vários Cupidos com os quais interage. A cena conta também com a presença de Baco, com seu tirso, posicionado sobre um pedestal:

\footnotetext{
${ }^{564}$ Ov., Am. 1.6.33-39.

565 Tradução de L. A. Bem.

${ }^{566}$ Pichon (1991:257): Saeuus dicitur Amor quia in homines crudeliter regnum exercet. Tib. 1.6.3, 1.2.88, Prop. 1.1.6, Hor., Carm. 2.8.14, e Apul., Met. 4.32-ss..

${ }^{567}$ Ov., Am. 1.6.57-62.

${ }^{568}$ Tradução de L. A. Bem.
} 


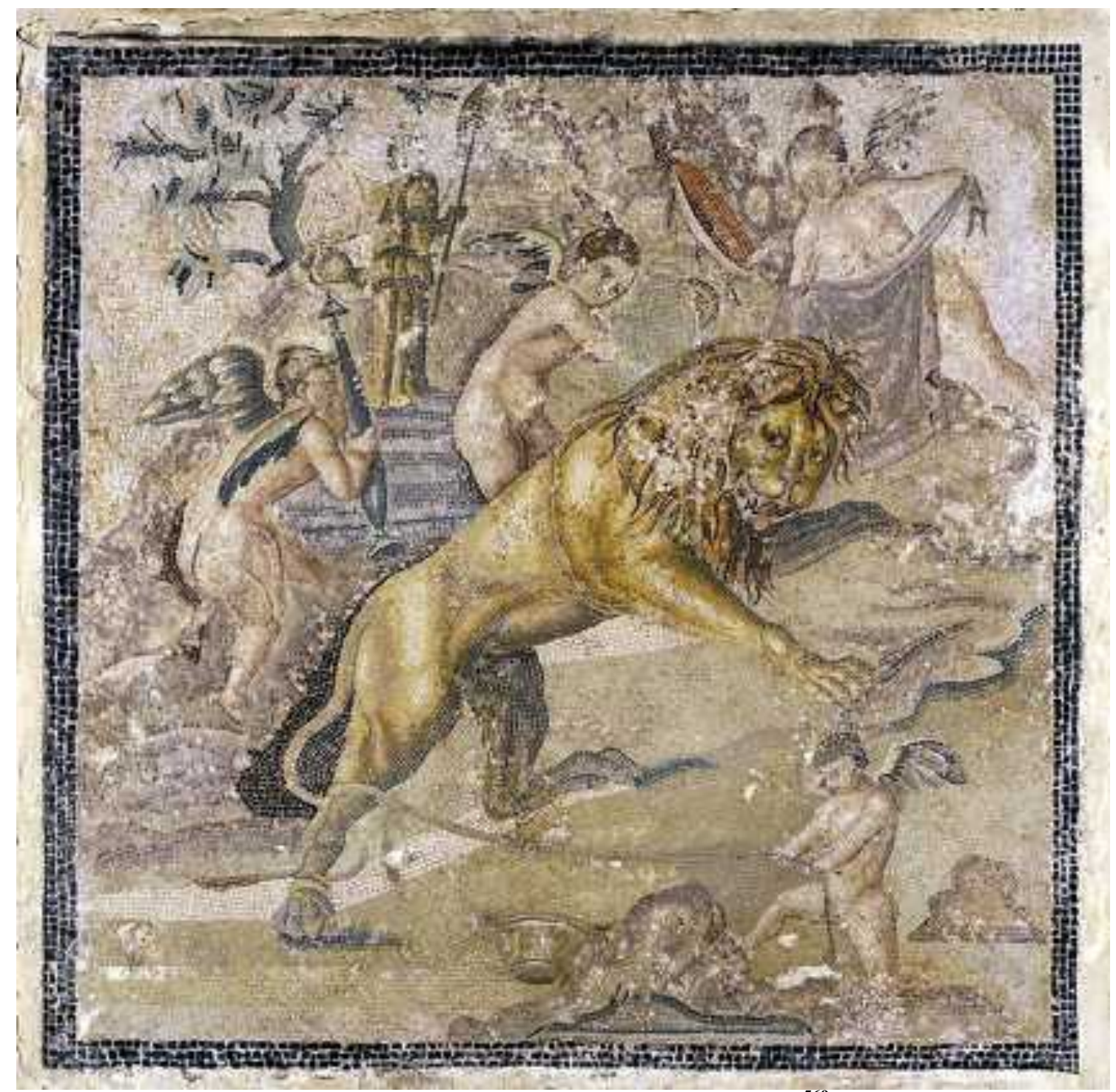

Figura 39. Turba de Cupidos em caça ao Leão ${ }^{569}$

Em Roma esse motivo tornou-se comum, com diversas variantes. Havia outro mosaico como esse no triclinum na Casa do Centauro ${ }^{570}$, em Pompeia, em que figuram Cupidos dominando um leão em posição semelhante, com a presença de Dioniso e Mênades.

O leão é tradicionalmente empregado na composição de símiles e metáforas que aludem à força e à coragem. Lausberg ${ }^{571}$ ensina que:

\footnotetext{
${ }^{569}$ The British Museum. mosaic pavement. Registration number: 1856,1213.5. Object type: pavement. Culture/period: Roman. Date: 70BC-10BC. Findspot: Naples. Material: stone. Technique: mosaic. Dimensions: Length: 37.7 centimetres. Height: 37.2 centimetres. Thickness: 6 centimetres (max.). The panel is an emblema, a decorative element designed to be the central point of an otherwise plain floor or wall. Department: Greek \& Roman Antiquities.

${ }^{570}$ Museo Archeologico Nazionale di Napoli, Napoli, Itália. Inv. 10019. Leone e Amorino tra Dioniso i Manade. Casa del Centauro (VI, 9, 3). Triclinio.

${ }^{571}$ Lausberg (2004:238).
} 
O símile, que é empregado como locus comprobativo e como ornatus consiste em uma qualidade que seja comum a várias (pelo menos duas) coisas. A qualidade que é comum a coisas semelhantes, chama-se tertium comparationis (por exemplo, a fortaleza e a rapidez do leão e de Ulisses).

Podemos também vê-lo como exemplo de metáfora e de símile na retórica de Aristóteles. Paulo Martins ${ }^{572}$ recorda a lição de Aristóteles acerca do símile e da metáfora:

Ensina Aristóteles em 1406b, ou melhor, no III livro, IV capítulo, portanto um significado diferenciado, lá o termo é indicado como tropo para indicar o símile e a metáfora e não mais a representação material. Propõe: ***... "o eikón também é metáfora". Ainda nos induz a entender que não só a metáfora é um eikón, como também explica que o símile o é. Ambos difeririam por um pequeno detalhe. Exemplifica: "lançou-se como um leão" 573 - é um eikón - símile. Enquanto: "lançou-se leão" é um eikón - metáfora. Os eikones, assim, são símiles e metáforas, que trocam os valores contidos nos termos a partir de uma relação de semelhança.

O leão associa-se miticamente a Baco e a Hércules, dois deuses que, por sua vez, associam-se a Cupido, como podemos observar em diversos exemplos nas artes em Roma.

A relação entre Hércules e Eros é mais explicitada nas artes do que na poesia. Nesse camafeu romano do séc. I a.C., Eros subjuga Hércules com o laço, atando suas mãos, do mesmo modo que os Erotes atam o leão na cena de caça do mosaico acima. Nesse sentido, ele supera Hércules (a força, a coragem, o leão), mantendo-o sob o seu jugo:

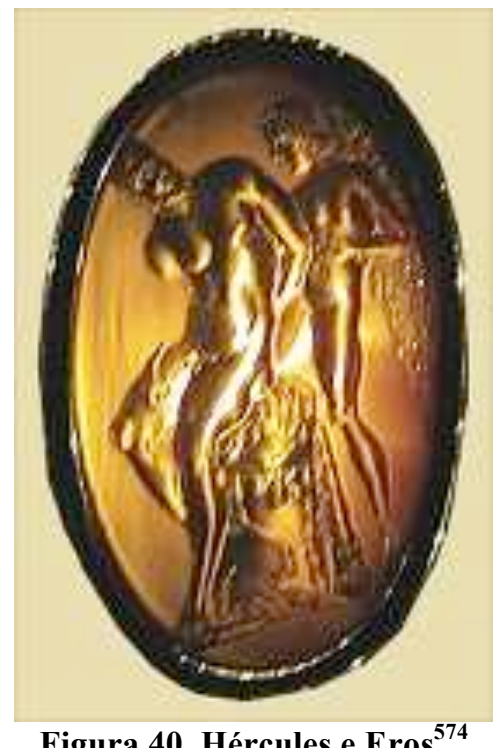

\footnotetext{
${ }^{572}$ Martins (2006:92): Tropos na Eneida e uma imagem metafórica. O artigo propõe uma discussão a respeito do símile e da metáfora em diferentes meios miméticos.

${ }^{573}$ Homero, Il., 20.164.

${ }^{574}$ Kunsthistorisches Museum, Viena. Heracles; Eros. Roman, first century BCE. Hercules sits on a mound with his lionskin and club while Cupid binds his hands behind his back, an allegory for the conquest of strength by erotic passion. Credits: Barbara McManus, 2006. Keywords: jewelry; mythology;
} 
O tema de Hércules e Ônfale, encontrado nas Heróides ${ }^{575}$ de Ovídio, é um exemplo de seruitium amoris, e evidencia a humilhante escravidão amorosa do herói diante da rainha da Lídia. Nos versos de Ovídio, a história é narrada sob a perspectiva de Dejanira, e notam-se apenas os efeitos da ação do deus, principalmente o jugo a que Hércules é submetido ${ }^{576}$; porém, em outras artes, a presença do deus é explicitada. Na pintura ${ }^{577}$ abaixo, Hércules jaz deitado com roupas femininas diante de Ônfale e é dominado por um grupo de Erotes. A embriaguez, evidenciada pelo uso da guirlanda e por sua posição corporal lânguida, pressupõe que ele sofre também a ação de Dioniso $^{578}$. Um grupo de Amorini une forças para alçar a clava do herói, símbolo de seu poder, e posicioná-la no alto sobre uma estrutura quadrangular. Ônfale, atendida por duas amas, observa a cena do alto; ela segura o leque de folha de lótus, símbolo de autoridade e beleza, semelhante ao que vimos em outras pinturas nas mãos de Cupido. Um Puer posiciona-se sobre a cabeça de Hércules, indicando o domínio sobre a razão:

\footnotetext{
${ }^{575}$ Ov., Ep. 9: amor de Hércules e Ônfale sob a perspectiva de Dejanira.

${ }^{576}$ Colar feminino como "jugo", cf. Ov., Ep. 9.57-58: vidit in Herculeo suspensa monilia collo illo, cui caelum sarcina parva fuit.

577 Sobre esta pintura, cf. Sampaolo (2009:258).

${ }^{578}$ Segundo Sampaolo (2009:258) em algumas variantes desse quadro figuram Dioniso e seu tiaso.
} 


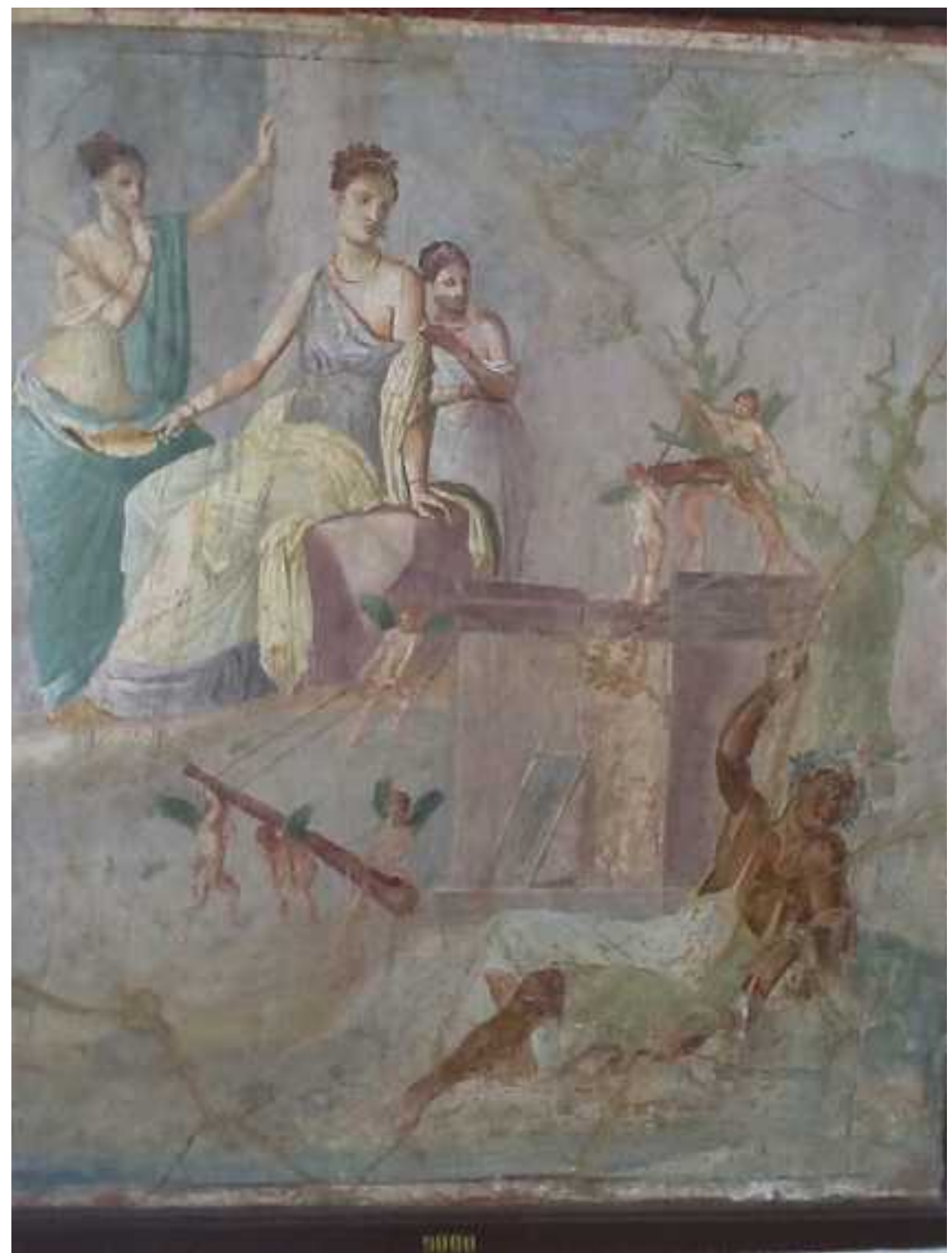

Figure 41. Hércules e Onfale ${ }^{5 / 9}$

$\mathrm{Na}$ estatueta abaixo, Eros veste a indumentária de Hércules, numa sobreposição de atributos. A pele de leão, amarrada na frente, cobre sua cabeça e pende de seus

\footnotetext{
${ }^{579}$ Museo Archeologico Nazionale di Napoli, Napoli, Itália. Inv. 9000. Eracle ed Onfale. Pompei. Casa del Principe di Montenegro, VII, Insula Occidnetalis, 10 tricínio (6?). Alt. cm. 95. Largh. cm. 81; 25-35 d.C..
} 
ombros sobre toda parte traseira do corpo; bandanas adornam sua coxa arredondada; as asas bem abertas e a posição corporal sugerem movimento:

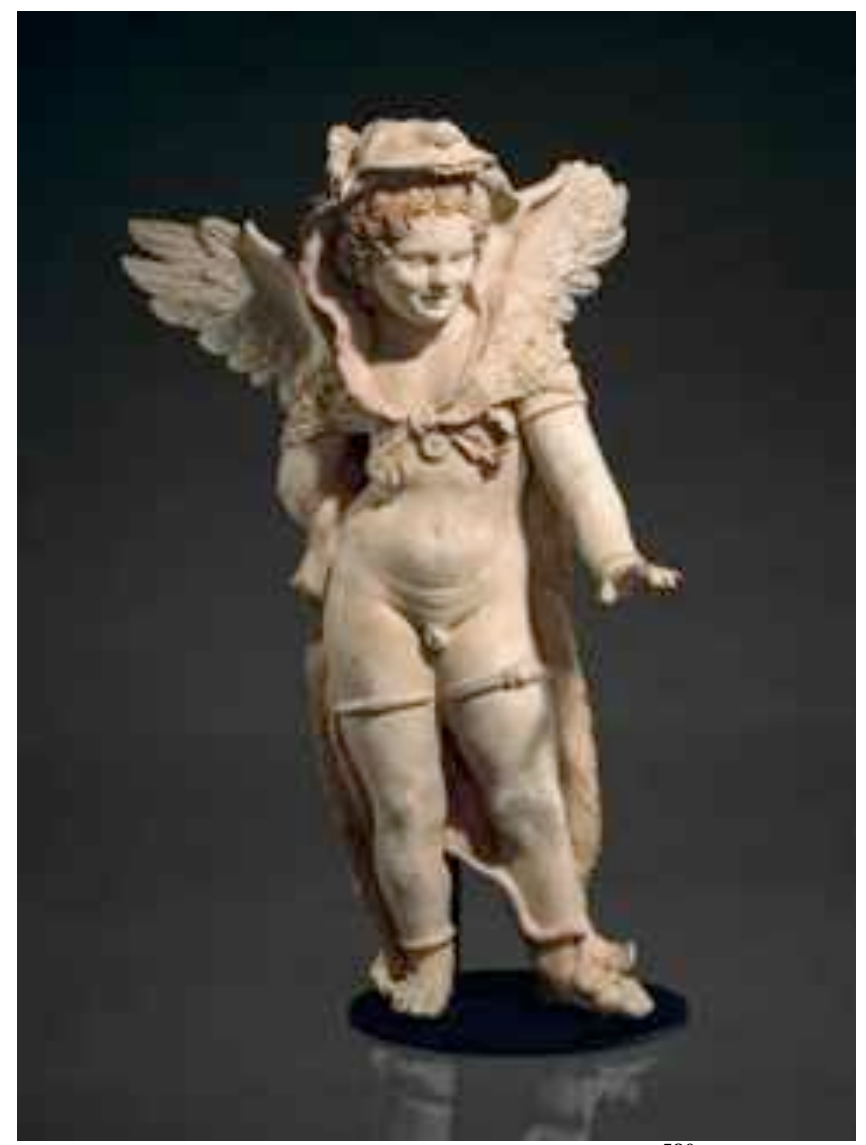

Figura 42. Eros com pele de leão ${ }^{580}$

\footnotetext{
${ }^{580}$ MFA, Boston. Statuette of Eros wearing the lionskin of Herakles. Greek, East Greek, Hellenistic Period, 1st century B.C. Height: $40 \mathrm{~cm}$ (15 3/4 in.). Terracotta. Classification: Sculpture. Catalogue: Burr, Terracottas from Myrina (MFA), no. 017; Highlights: Classical Art (MFA), p. 090. Museum of Fine Arts, Boston. Statuette of a winged Eros, masquerading as Herakles. There are traces of red on chest, stomach and pupils of eyes; pink on left leg; reddish-brown on hair; yellow and red outside the lion's skin, red on inside of lion skin; yellow with super-imposed gilding on both wings, circlet and left thigh ornament; yellow in bracelet of upper left arm; pink on both wings. Fingers, apart from right thumb, are missing and the left wing is mended. Yellow-red clay.
} 


\section{Nox, Amor et uinum}

A sobreposição de atributos é comum na arte romana, como vimos em alguns exemplos acima, e parece ocorrer também no mosaico abaixo, de motivos dionisíacos, que pertenceu à Casa do Fauno em Pompeia, ocupando, segundo Dunbabin ${ }^{581}$, o piso central do que provavelmente foi uma sala de jantar (triclinium) na casa. De acordo com essa autora, mosaicos refinados como esse eram uma raridade, e são ícones do gosto e do luxo helenístico que caracterizava a aristocracia romana a partir da metade do século II a.C., especialmente em seus ambientes privados. De acordo com a autora, esse mosaico é mais tardio do que a casa, sendo datado de cerca de 100 a.C., e provavelmente foi feito por artesãos gregos. Nele figura um menino alado, montado em um animal que sobrepõe características de felinos, com uma juba de leão e pele de tigre. A criança sobrepõe características de duas divindades: Cupido, como um menino alado e nu; e Dioniso, com a guirlanda, o felino e o cálice. Motivos simposiásticos contornam a figura, como máscaras de teatro, guirlandas e um tirso:

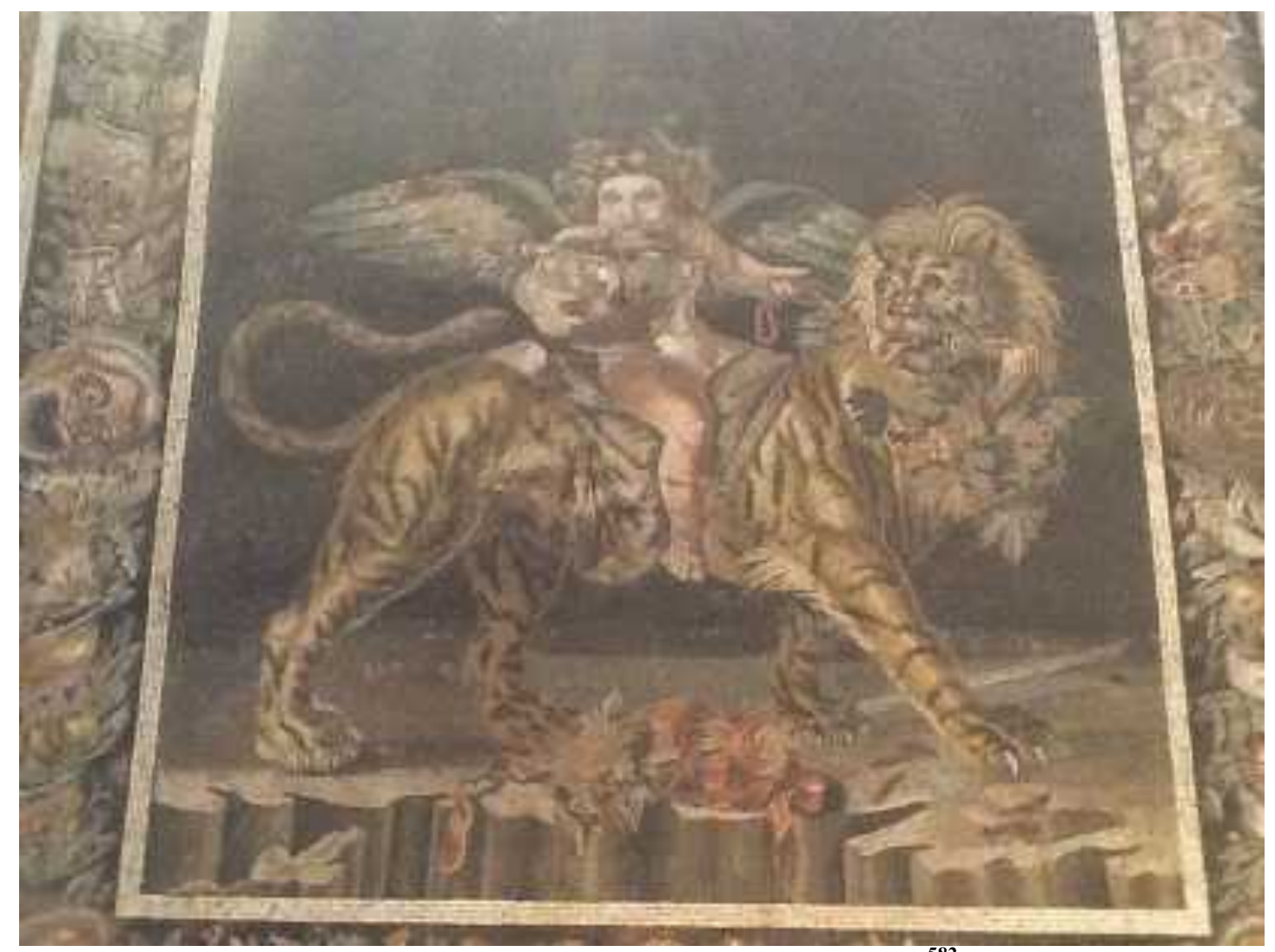

Figura 43. Menino alado montado em um tigre

\footnotetext{
${ }^{581}$ Dunbabin (2011: 43).

${ }^{582}$ Museo Archeologico Nazionale, Napoli, Itália. Inv. 9991. Dioniso fanciulo su tigre. Mosaico. Casa del Fauno (VI 12, 2), Pompei. 100 a.C.. $1.63 \mathrm{~m} \mathrm{X} 1.63 \mathrm{~m}$..
} 
Esse mosaico, como dissemos, é de tipo helenístico, e pode ser comparado a outras obras, como o mosaico de Dioniso montado em um tigre da Casa das Máscaras ${ }^{583}$ em Delos; e, especialmente, ao mosaico da Casa de Dioniso ${ }^{584}$, também em Delos, em que um adulto do sexo masculinho, alado, usando uma guirlanda e portando um tirso, está montado em um tigre; para Dubabin, tal figura assemelha-se a Dioniso, mas a presença das asas sugere que seja um daimon dionisíaco, e não o deus.

O mosaico do menino alado da Casa do Fauno, de acordo com a classificação do Museu de Nápoles, onde a obra se encontra, é um Dioniso criança conduzindo o seu tigre. Figuração semelhante a essa é encontrada em outros objetos de arte romanos, como jóias ${ }^{585}$ que pertencem ao acervo do Museu Britânico; porém a dúvida permanence por parte dos pesquisadores quanto à interpretação do motivo, sendo categorizadas como "Eros ou Dioniso". Em minha opinião, a enigmática figura alada do Casa do Fauno pode ser, tanto quanto a estatueta de Eros com a indumentária de Hércules, uma sobreposição de figurações, nesse caso de Cupido e Baco, duas divindades com forte presença no imaginário romano, e que figuram juntas especialmente em cenas simposiásticas.

Segundo Guerreri ${ }^{586}$, as figurações de Eros e Dioniso aparecem associadas com maior frequência a partir do século V a.C. na Grécia. Eros com Dioniso e seu séquito figuram, em diversas artes, principalmente em cenas que sugerem o estado de êxtase provocado pelo vinho, pela música e pelo canto, um cenário favorável às alegrias do amor.

Tendo comentado anteriormente algumas das principais tópicas de Amor no papel de agente desencadeador das paixões que afetam os personagens envolvidos em

\footnotetext{
${ }^{583}$ Dionysus. House of the Masks, Delos. House; in the theater quarter to the southeast of the theater. Date: ca. 120 BC - 80 BC. Region: Cyclades. Period: Hellenistic. Mosaic pavements in 4 rooms depicting scenes related either to Dionysos or to drama. May have served as a hostel for visiting troops of performers.

${ }_{584}$ Dionysus (?) House of Dionysus, Delos. Last quarter of $2^{\text {nd }}$ cent. B.C. 1.57 m X 1.29 m. C. $130-88$. B.C.

${ }^{585}$ Cf.: 1) The British Museum. Registration number: 1923,0401.472. Gem of glass paste imitating lapis lazuli, engraved with Eros riding on a lion, holding a goad in his right hand. 1stC-3rdC.; 2) The British Museum. Registration number: 1923,0401.474. Gem of glass paste imitating sard, engraved with Eros or Dionysos with his right hand raised, seated sideways a lion or panther, which gallops to the right with its face turned to the front. 1stC-3rdC.

${ }^{586}$ Guerreri (2007:36)
} 
seus jogos eróticos, observaremos agora, especificamente, como essas relações se estabelecem no ambiente do simpósio, lugar presidido por Amor e Baco.

Arkins $^{587}$ resume as várias abordagens da matéria erótica em diversos discursos em Roma, observando que, nesse aspecto, a poesia latina do final da República dividiuse em duas vertentes principais: a de Catulo e a de Lucrécio. Catulo evidenciou a ideia da ligação com uma única mulher, que ele eternamente ama e odeia, louva e vitupera; os elegíacos augustanos por sua vez, também investiram na constância amorosa, e, com as tópicas militia e seruitium amoris, atribuíram ao homem o páthos amoroso normalmente reservado à mulher. Lucrécio, por outro lado, com base na doutrina de Epicuro, considerava o amor como algo perturbador da ataraxia, necessária ao filósofo, defendendo o sexo descomprometido; nesse sentido, Virgílio e especialmente Horácio tendem a apresentar em seus poemas relações que envolvem mais de uma mulher e também homens, e o sexo torna-se algo mais volúvel e fácil ${ }^{588}$. Nas Sátiras ${ }^{589}$, nas palavras de Damasipo, Horácio é acusado de ter mille puellarum, puerorum mille furores (mil paixões por mil moços e moças).

Boa parte dos amores na poesia latina têm como cenário o simpósio. Compararemos especificamente a presença de Amor e o tratamento dado à matéria erótica em poemas simposiásticos, contrastando aspectos do epodo 11 de Horácio com passagens de algumas elegias augustanas, observando as afecções dos amantes e tópicas como o paraklausithyron, seruitium amoris e remedia amoris.

\section{Uma epifania dionisíaca}

Propércio inicia a elegia 1.3 com uma cena epifânica em que os humanos comparam-se aos deuses e aos heróis: Cíntia assume traços de Ariadne, ele os de Baco, e os pueri, com suas tochas, podem representar os Cupidos:

\footnotetext{
Qualis Thesea iacuit cedente carina languida desertis Cnosia litoribus; qualis et accubuit primo Cepheia somno libera iam duris cotibus Andromede; nec minus assiduis Edonis fessa choreis qualis in herboso concidit Apidano: talis visa mihi mollem spirare quietem Cynthia consertis nixa caput manibus, ebria cum multo traherem vestigia Baccho,
}

\footnotetext{
${ }^{587}$ Arkins (1993:106).

${ }^{588}$ Hor., S. 1.2199: Venus facilis.

${ }^{589}$ Hor., S. 2.3.325.
} 
et quaterent sera nocte facem pueri. ${ }^{590}$

Como Ariadne tombou exaurida na praia deserta quando a nau de Teseu partiu; como Andrômeda, filha de Cefeu, deitou-se recostada, no primeiro sono, já livre dos duros recifes; e não menos cansada por danças frequentes, como uma Bacante caída no ervoso Apidano assim, me pareceu respirar sua suave quietude, Cíntia, com a cabeça apoiada em mãos inseguras, quando, com muito vinho, eu arrastava passos ébrios e escravos agitavam as tochas ao cair da noite ${ }^{591}$

O tema explorado nos versos acima de Propércio era comum também em outras artes, como a pintura. No quadro abaixo ${ }^{592}$, a heroína Ariadne posiciona-se em primeiro plano, com um manto cobrindo parte seu corpo, ao reclinar-se adormecida nos braços de Hipnos. Eros, em pé, ao lado, levanta o manto de Ariadne com uma das mãos e com a outra faz um gesto indicando-a para Dioniso; que está em segundo plano, ao centro, com coroa de hera, manto, sandálias e tirso; e ao seu redor posicionam-se os membros do séquito: Sileno, mênades e sátiros:

\footnotetext{
${ }^{590}$ Prop., 1.3.1-10.

591 Tradução de P. Martins.

${ }^{592}$ Segundo Sampaolo (2009:340).
} 


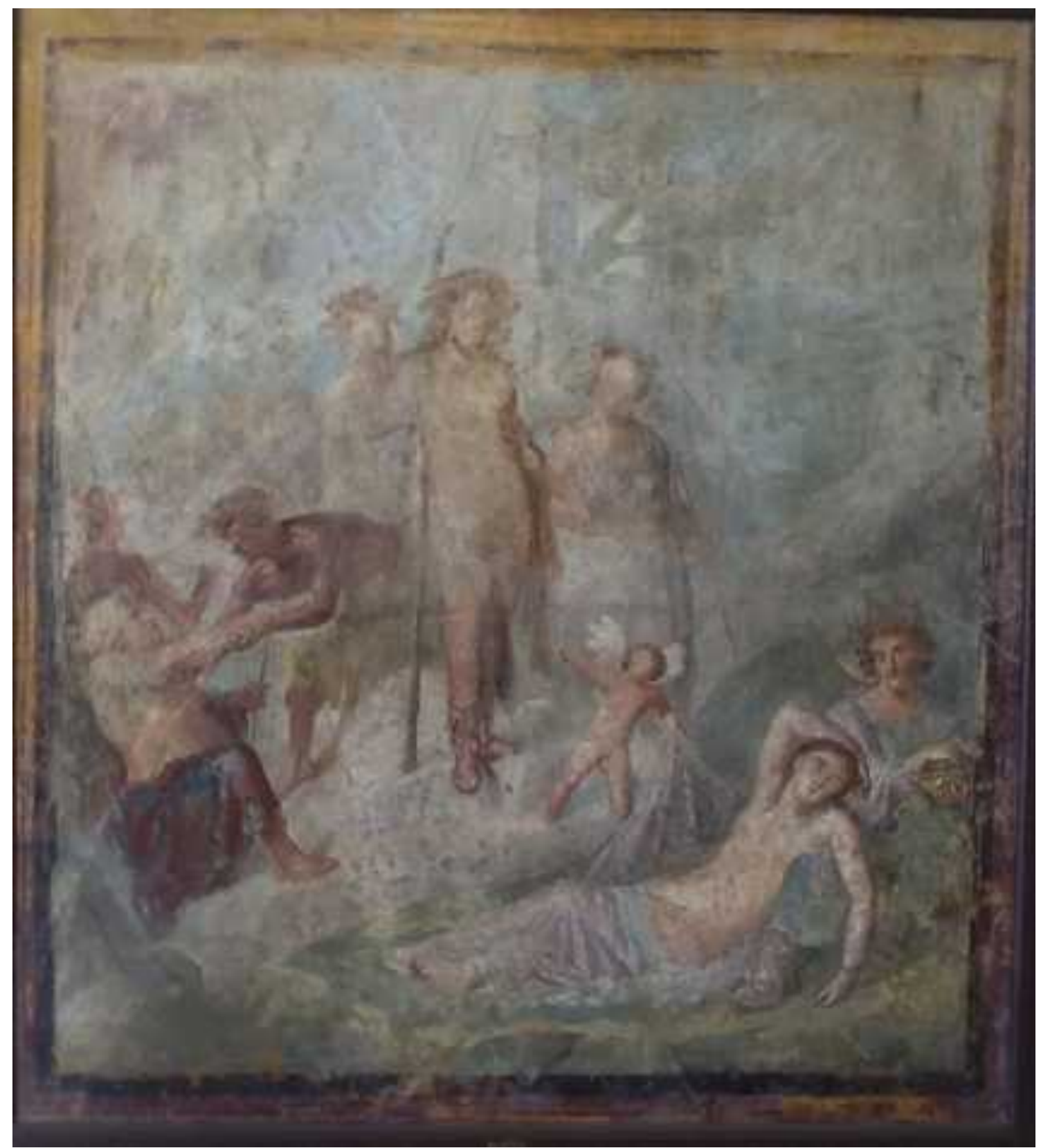

Figura 44. Epifania de Dioniso ${ }^{593}$

Depois da cena dionisíaca, Propércio transfere-se para um ambiente que inclui Cíntia adormecida em seu leito, e ele com sua guirlanda e embriaguez, resquícios da recente presença em um simpósio. Na presença de Libere Amor ${ }^{594}$, que têm em comum a dureza ${ }^{595}$ e poder de despertar o ardor, ele observa a amada com olhos fixos. Esses deuses desencadeiam excitação física e mental, acendendo a chama que move o poeta

\footnotetext{
${ }^{593}$ Museo Archeologico Nazionale di Napoli, Nápoles, Itália. Inv. 9278. Pompeia, Casa dei Capitelli Colorati, VII 4, 51-31, oecus 24. Alt. $118 \mathrm{~cm}$; larg.: $106 \mathrm{com}$. 45-79 d.C.. Proveniente dal registro mediano dela parete ovest ed incorniciato da un bordo ad astragali in parte lasciato in situ.

${ }_{594}$ Amor e Líber: Tibulo 3.6; Ov., Ars 1.232.

${ }^{595}$ Pichon (1991:136): durus Amor, durum Fatum, cum in homines grauiter incumbunt: Prop. 1.6.36.
} 
em direção à Cíntia. Ele ameaça "apresentar sua arma", porém não ousa perturbar o sono tranquilo da amada, evitando despertá-la, como se fosse um sátiro prestes a surpreender uma bacante, porém temeroso de sua fúria ${ }^{596}$ :

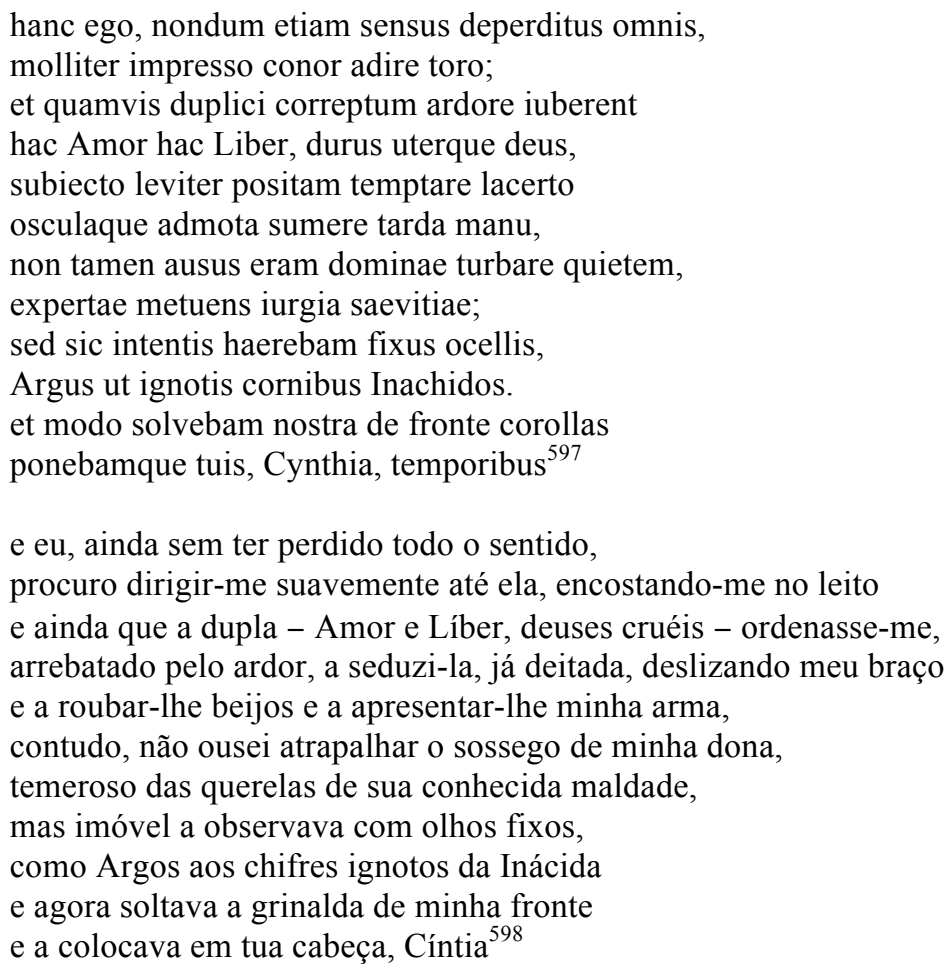

A bebida, em geral, aparece na poesia como algo que proporciona um estado propício ao amor, não somente entre os latinos, mas também entre os gregos, como observa Calame ${ }^{599}$ :

Na poesia arcaica o poder do amor é percebido primeiramente pela doçura que invade os sentidos com uma sensação de relaxamento. Essa sensação não é apenas transmitida por esse sabor, mas às vezes, certamente, por um líquido como a água ou o vinho. No entanto, é um doce prazer que também pode ser proporcionado pelo sono e, sobretudo, pela música em todas as suas formas: a voz, a canção e a melodia da flauta, o som da lira, em suma, a Musa.

A perda dos sentidos, o ardor, o sono, na elegia 1.3 de Propércio, são efeitos proporcionados por Amor e Líber.

Invertendo os papéis, Propércio tira a guirlanda de sua fronte e a coloca na testa de Cíntia, introduzindo-a ao universo de Baco; e no último verso, Propércio entrega-se

\footnotetext{
${ }^{596}$ Miller (2002:171).

${ }^{597}$ Prop., 1.3.11-22.

${ }^{598}$ Tradução de P. Martins.

${ }^{599}$ Calame (1999:14).
} 
ao sono reparador ${ }^{600}$, Sopor, tal como Ariadne abandonada, um final que sugere também a exaustão sexual.

\section{O simpósio elegíaco}

$\mathrm{Na}$ elegia 2.30b, Propércio estabelece o simpósio como o lugar de sua poesia erótica. Com essa introdução endereçada a Cíntia, que lembra Catulo 5, o lamento elegíaco dá lugar à celebração com a amada no simpósio, lugar próprio para o amor, onde soa a douta tíbia:

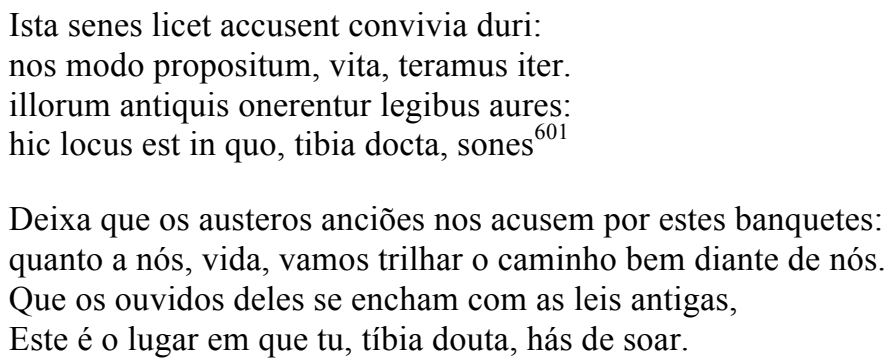

Ele proclama fidelidade a essa mulher, protestando contra uma possível censura:

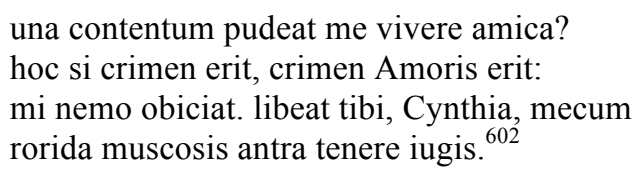

Devo envergonhar-me de viver contente com uma amiga?

Se isto for crime, é um crime de Amor:

que ninguém me censure. Que te agrade, Cíntia, ficar

comigo em uma gruta orvalhada nos montes cobertos de musgo.

O vocabulário e os argumentos presentes nesse poema aproximam-se do discurso judiciário $^{603}$, como se o poeta estivesse defendendo-se da acusação por um crime que ele alega não ter cometido. Palavras como lex e crimen são adaptadas para o âmbito dos gêneros poéticos, sendo antiquae leges ${ }^{604}$ uma referência às "leis" da poesia elevada ${ }^{605}$ e crimen amoris à prática da poesia erótica. Considerando-se que essa amica é uma metáfora para a elegia, o poeta estaria violando as antiquae leges dos anciãos, ao

\footnotetext{
${ }^{600}$ Prop., 1.3.45-46.

${ }^{601}$ Prop., 2.30b.13-16.

${ }^{602}$ Prop., 2.30b.23-26.

${ }^{603}$ Para discussões sobre a linguagem jurídica na argumentação, cf. Gunther (2006:212); Martins (2009:73).

${ }^{604}$ Prop., 2.30b. 15.

${ }^{605}$ Cairns (1971:210).
} 
dar preferência aos temas eróticos destinados a seduzi-la ${ }^{606}$. Ele defende-se da acusação alegando que o ambiente do simpósio, presidido por Amor, não impede esse modo de vida; assim sendo, pelas leis do conuiuium, ninguém tem direito de opor-se às suas escolhas. A coação do alado Amor é outro argumento do poeta para justificar sua conduta supostamente "criminosa" 607 :

$$
\begin{aligned}
& \text { quod si nemo exstat qui vicerit Alitis arma, } \\
& \text { communis culpae cur reus unus agor? }{ }^{608} \\
& \text { Pois se não existe ninguém que tenha vencido as armas do Alado, } \\
& \text { por que somente sou acusado como único réu de uma culpa comum? }
\end{aligned}
$$

O crimen amoris tem também o respaldo de Baco: ao final do poema, Cíntia é figurada em meio ao coro das Virgens ${ }^{609}$ conduzido por ele. A menção a esse deus em associação à figura de Cynthia como $\operatorname{docta}^{610}$ puella dá ênfase ao caráter engenhoso e erudito da poesia de Propércio e atribui autoridade ao poeta, que, ao final do poema, irá adornar a fronte com a hera ${ }^{611}$, antecipando o triunfo da sua poesia na transição para o Livro III.

Em suma, Amor e Baco agem em conjunto nesse poema: o primeiro determinando as leis, e o segundo estabelecendo o cenário dionisíaco da poesia erótica de Propércio em que Cíntia, como Musa, é figura central.

$\mathrm{Na}$ pintura abaixo, Amor figura nos braços de uma Mênade ${ }^{612}$, indicando a intimidade desse deus com os personagens do universo dionisíaco. Ele segura uma flor com a mão direita, e a Mênade tem a testa adornada por uma guirlanda e veste uma túnica que deixa o braço e parte do tronco à mostra:

\footnotetext{
${ }^{606}$ Pichon (1991:158): Furtivus Amor: seu de amantibus adeo sese inuicem amare consuetis ut quase coniuges esse uideantur. Outras ocorrências, cf.: Tib. 1.5.75; 1.8, 35, 57; 2.6.5; 4.3.21; Prop. 4.8.34; Ov., Am. 1.4 .18 e $64 ; 2.5 .6 ; 2.8 .3,8 ; 2.19 .39$.

${ }^{607}$ Crimen amoris em epigramas, cf. A. P. 5.100.

${ }^{608}$ Prop. 2.30b.31-32.

${ }^{609}$ Prop. 2.30b.38.

${ }^{610}$ Sobre a importância do adjetivo docta, cf. Lyne (1974:246).

${ }^{611}$ Prop. 230b.39: sacer corymbus.

612 Sampaolo (2009:265).
} 


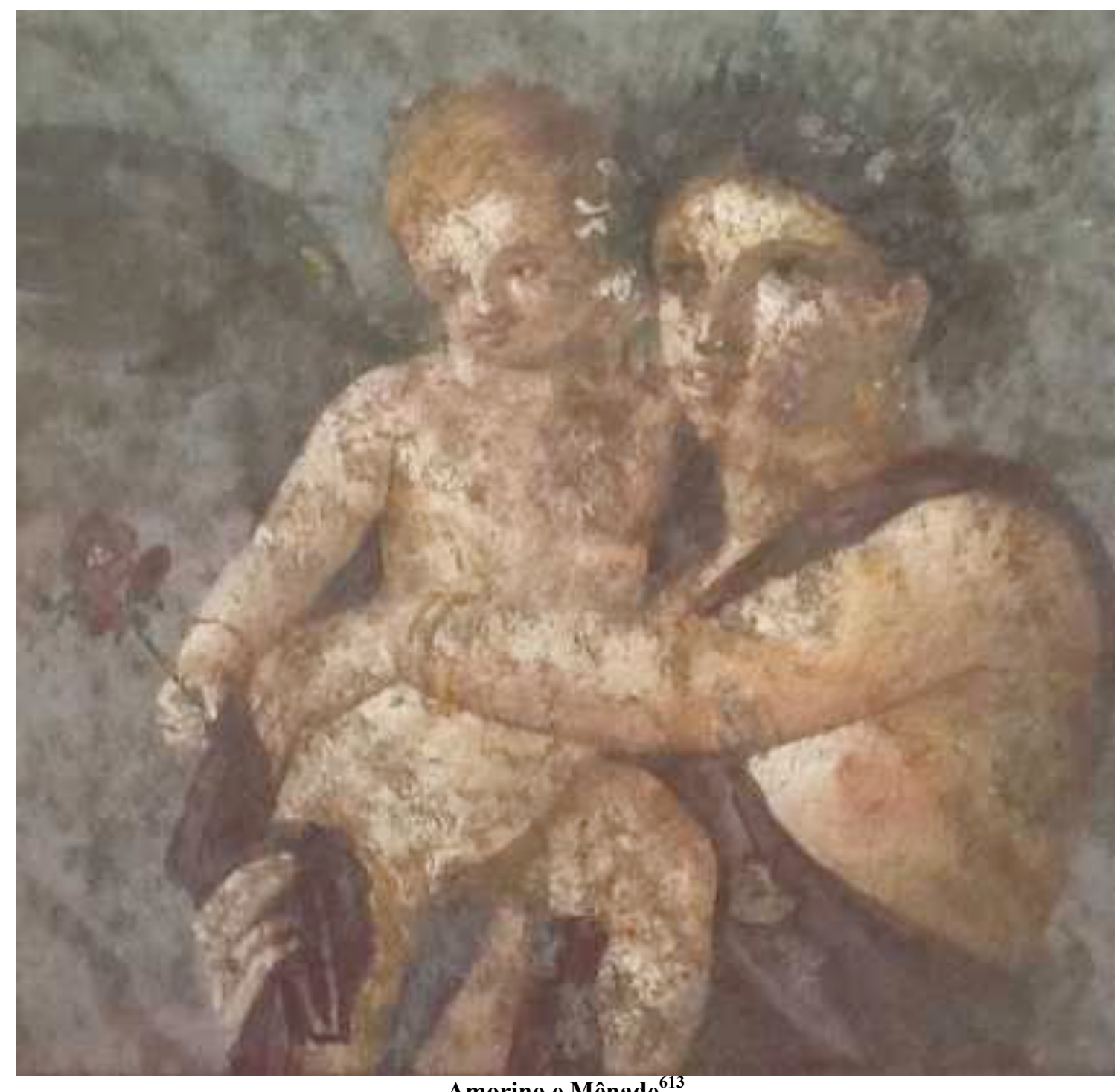

Amorino e Mênade ${ }^{613}$

Cíntia participa do universo dionisíaco da música e do vinho, e, tal como Ariadne $^{614}$, é iniciada nos mistérios de Dioniso, misturando-se ao seu séquito. O tema figurado no painel abaixo é o da iniciação de Ariadne. A heroína, vestindo uma túnica longa, está sentada em um banco ao centro da figura; e com a mão direita segura um cântaro. Uma mênade oferece a bebida armazenada em um oinochoe. Uma pequena cabra saltitante posiciona-se aos seus pés. Um Sileno barbado, adornado por guirlanda e clâmide esvoaçante, segura um skyphos. Aos pés do Sileno, uma serpente emerge de dentro de uma cesta. Cupido equilibra-se em pé sobre os galhos de uma videira, planta símbolo de Baco, da qual pende uma siringe, uma bolsa com uvas e um bastão nodoso. Ele estende um véu que liga os ramos da videira a um pé de louro, planta de Apolo:

\footnotetext{
${ }^{613}$ Museo Archeologico Nazionale di Napoli, Nápoles, Itália. Inv. 110591. Menade e Amorino. Pompei, Casa di L. Cecilius Iucundus. V 1, 26, tablino (i), parete nord. Alt. cm. 45; largh. cm. 45; 35-45 d.C.

${ }^{614}$ Prop., 2.3.18.
} 


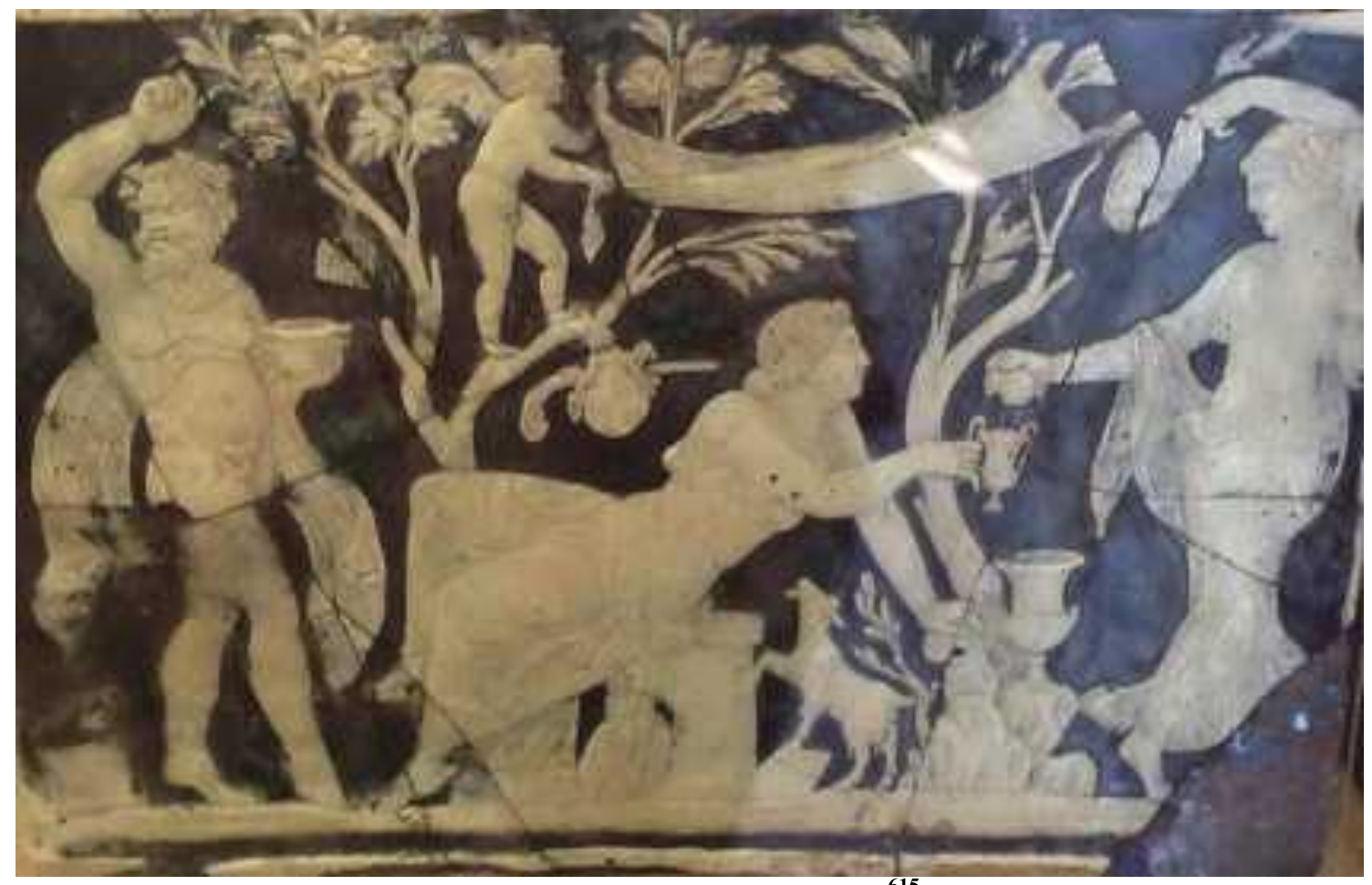

Figura 45. Iniciação de Ariadne (15 $^{215}$

\section{O simpósio iâmbico}

Horácio endereça o epodo 11 a Pétio, um amigo a quem ele confidencia detalhes sobre os amores e a poesia, dizendo, nos primeiros versos, ter sido golpeado gravemente por Amor, algo que afeta sua produção poética, tal como ele irá detalhar ao longo do poema:

Petti, nihil me sicut antea iuvat scribere versiculos amore percussum gravi, amore, qui me praeter omnis expetit mollibus in pueris aut in puellis urere. ${ }^{616}$

\footnotetext{
${ }^{615}$ Museo Archeologico Nazionale di Napoli, Nápoles, Itália. Pannello con iniziazione di Arianna (153651) Il pannello, rinvenuto come materiale sporadico insieme ad un altro conservato nel Museo Archeologico Nazionale di Napoli uguale per tema e dimensioni (inv. 153652), realizzato con una tecnica che lo qualifica come manufatto di pregio, doveva costituire ornamento per una decorazione di una parete $\mathrm{o}$, più verosimilmente, di un mobile in legno, al posto delle più comuni tarsie in avorio. Pannelli come questo in vetro cammeo sono estremamente rari, se non unici, probabilmente opera delle stesse botteghe in grado di produrre capolavori come il celebre "Vaso blu" (inv. 13521) del Museo Archeologico Nazionale di Napoli o il cd. "Vaso Portland" del British Museum. Venivano prodotti saldando insieme due lastre ottenute colando vetro fuso in matrici, dopo averle sovrapposte e introdotte nel forno. Successivamente si procedeva all'incisione della lastra superiore. Interessante notare, infine, che all'atto del ritrovamento presentava già tracce di usura e di restauro antico.
}

${ }^{616}$ Hor., Ep. 11.1-4. 
Pétio, em nada me agrada escrever versinhos como antes, tendo sido golpeado gravemente por Amor,

Amor, que mais que a todos me solicita

para arder em chamas por delicados moços ou moças.

A maioria das edições não grafa amor com maiúscula nos versos 2 e 3 , e nem os comentadores parecem ter certeza de que Horácio esteja referindo-se ao Amor personificado. Mankin ${ }^{617}$ sugere que "amor", nesses versos, seja como o "pothos" de Arquíloco $^{618}$, no liame entre a personificação e a afecção. Horácio dá maior ênfase aos efeitos do amor do que à figuração do deus em si, porém sabemos quanto é maleável o limite que distingue a personificação da afecção na poesia latina. Alguns elementos reforçam a ideia de que Horácio esteja referindo-se à personificação, como a utilização do verbo expeto, que, segundo Mankin, é usado mais para pessoas ou deuses do que para sentimentos ou coisas; um termo que pode significar desejar vivamente, suspirar por, apetecer, cobiçar, dirigir súplicas ou solicitar, o que lembra o chamado ao retorno às batalhas de Vênus de Odes 4.1, porém em um tom mais iâmbico. O verbo percutio, que significa golpear, bater com força, lembra a ação do Eros solta-membros, de Arquíloco $^{619}$, ou a do Eros ferreiro que golpeia com um martelo, de Anacreonte ${ }^{620}$. O verso 2 do epodo 11 lembra também um verso das Geórgicas de Virgílio ${ }^{621}$, ingenti percussus amore, em que talvez o termo amor também fique no limite entre a afecção e a personificação.

No epodo 11, o poeta, inconstante no amor, envolve-se com personagens que também são volúveis, promíscuos e indiscriminados nas relações. Ele relata ao amigo experiências eróticas do passado e do presente, além de fazer projeções para o futuro. Ináquia o pretere por um diues amator. Segundo Watson ${ }^{622}$, pela origem grega, este nome pode sugerir o tipo da prostituta; ou, como diz Mankin ${ }^{623}$, aludir ao epíteto de Io, filha de Ínaco, que possuía feições bovinas. Licisco, um puer delicatus, é o amor do presente. Seu nome quer dizer lobinho ${ }^{624}$ em grego, e pode ser uma referência a animais comum em iambos, e por outro lado, segundo Mankin, pode também aludir à prostituição.

\footnotetext{
${ }^{617}$ Mankin (1995:192-205).

${ }^{618}$ Arch., frag. 196. Eros solta-membros também em Safo, frag. 130 V.; e Hesíodo, Teog. 121.

${ }^{619}$ Arch., frag. 196.

${ }^{620}$ Anacr., frag. 413.

${ }^{621}$ Verg., Georg. 2.476.

${ }^{622}$ Watson (2003: 366).

${ }^{623}$ Mankin (1995:196).

${ }^{624}$ Mankin (1995:204).
} 
O éthos do poeta como amante de Ináquia mistura caracteres elegíacos, iâmbicos e cômicos. O aspecto elegíaco é evidenciado no lamento e nas lágrimas, e também em em algumas facetas poeta amator: a persona do pauper amator, que se gaba de ter unicamente seu ingenium como aliado na conquista amorosa, e a do exclusus amator, que perde a amada para o amante rico:

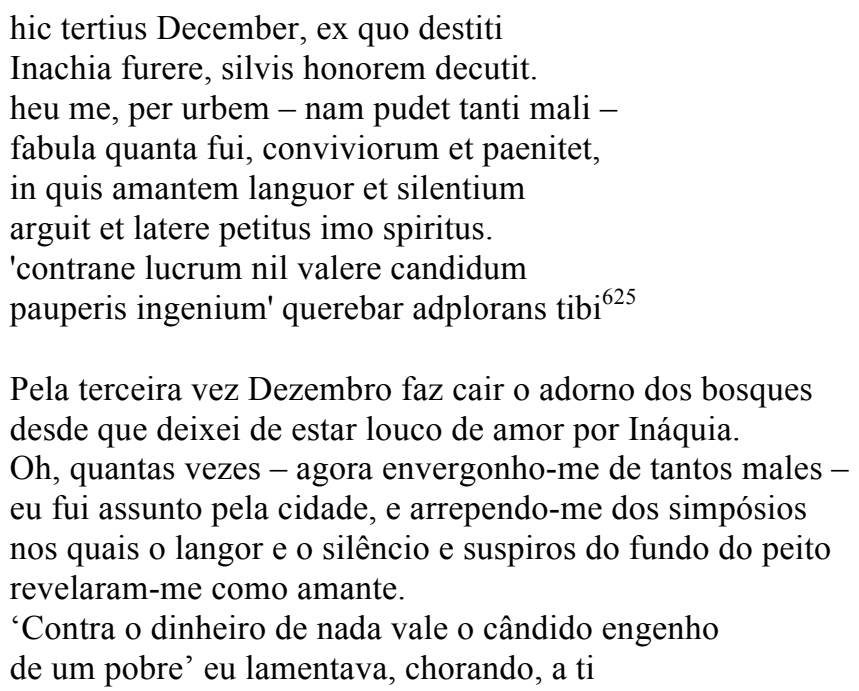

Uma face mais iâmbica e cômica do amator aflora nesses versos:

simul calentis inverecundus deus

fervidiore mero arcana promorat loco. ${ }^{626}$

enquanto eu me aquecia com o mais ardente vinho puro, e o impudente deus me fazia revelar segredos bem guardados.

Baco aparece como inverecundus deus, que desencadeia um comportamento mais expansivo no poeta, que, por sua vez, descontrola-se com as palavras e expressa impotência e raiva por ter sido abandonado:

'quodsi meis inaestuet praecordiis

libera bilis, ut haec ingrata ventis dividat

fomenta volnus nil malum levantia,

desinet inparibus certare summotus pudor.'627

Mas, se a bile fervesse livre em minhas entranhas, de modo a me fazer espalhar aos ventos esses ingratos lenitivos que nada aliviam a maligna ferida,

eliminada a causa da vergonha, eu cessaria de disputar com desiguais.

Horácio utiliza a tópica simposiástica do paraklausithyron, comum em epigramas, elegias, iambos e comédias, em que o amator humilha-se diante das portas.

\footnotetext{
${ }^{625}$ Hor., Epodos 11.5-12.

${ }^{626}$ Hor., Epod. 11.13-14

${ }^{627}$ Hor., Epod. 11.15-18.
} 
Depois de ter abertamente desafogado as mágoas, ele é mandado para casa, mas retorna à porta de Ináquia, e, ao tentar atravessá-la, quebra o flanco e o lombo:

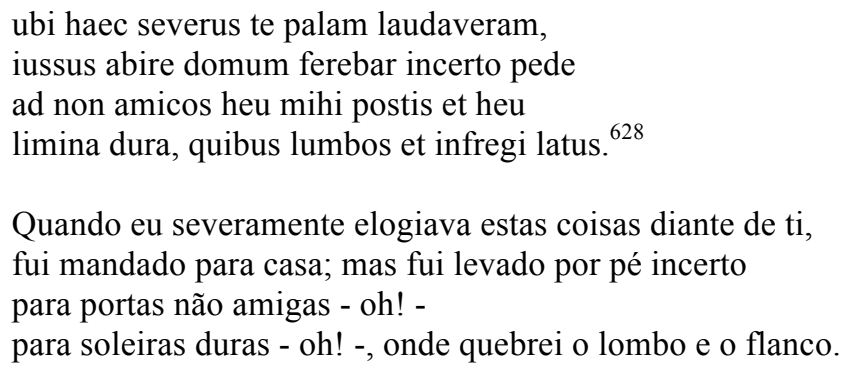

Horácio, nessa passagem, apela ao ridículo e à linguagem baixa e fisiológica do iambo, com expressões como "quebrar o lombo e o flanco".

Depois dessa incursão no passado, o poeta retoma o presente revelando seu ardor por Licisco, um puer delicatus. Seu furor parece não ter abrandado, mas apenas se direcionado para outro alvo, pois, se antes ele estava apaixonado por Ináquia, agora se prende a Licisco. Por outro lado, ele revela-se inconstante, pois mostra-se seguro de que pode esquecer Licisco imediatamente, subsitituindo-o por outro amor:

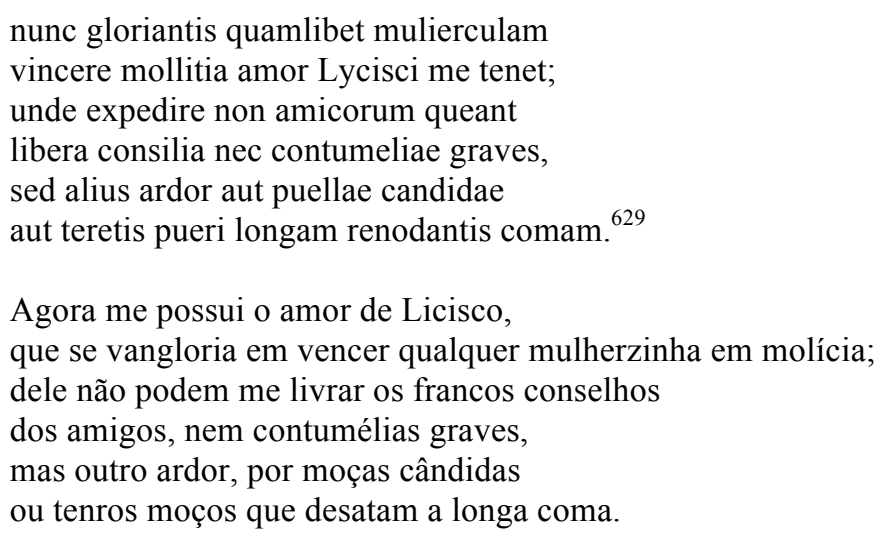

\section{Ligações amorosas em epodos e elegias}

Como pudemos observar, embora o epodo 11 de Horácio preserve elementos essenciais do iambo, ele não é dos poemas mais invectivos, mesclando elementos de outros gêneros. Newman ${ }^{630}$ questiona se esse poema pode ser considerado grave ou suave, optando por dizer que talvez os dois. Diz ele ${ }^{631}$ que, como parte do legado da poesia simposiástica de Arquíloco, a elegia foi realmente filha da iambiké ideia, e desse

\footnotetext{
${ }^{628}$ Hor., Epod. 11.19-22.

${ }^{629}$ Hor., Epod. 11.23-28.

${ }^{630}$ Newman (1997:128).

${ }^{631}$ Newman (1997: 179).
} 
ramo comum, tanto os Epodos de Horácio como as elegias augustanas preservam a presença de Eros e o ambiente do simpósio.

Como amante de Ináquia, Horácio é tomado de furor, uma afecção do passado, que o levava a escrever versinhos que ele já não quer mais, cobiçando novos amores por pueri e puella. Embora ele declare-se apaixonado por um só, ele demonstra abertura para viver outras paixões. Nesse sentido, a face do amator no epodo $11^{632}$ contrasta-se com a do amator elegíaco. Amor fere Propércio, o humilha e o submete ao seruitium amoris, tornando-o presa de uma única mulher, Cíntia, do qual ele não consegue desvencilhar-se, e à qual é obrigado a manter-se fiel. Mesmo sendo preterido, ele insiste, e não desvia os olhos daquela que é para sempre sua única musa e heroína:

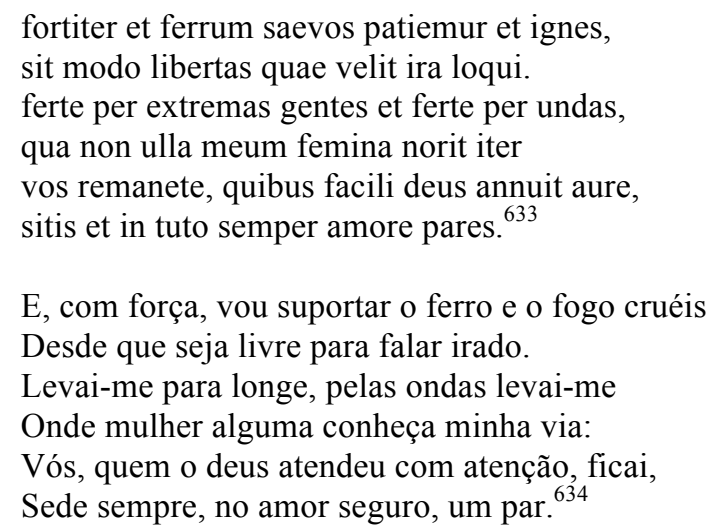

Ele recusa-se a traí-la, apesar da insistência do amigo Basso, poeta iâmbico:

Quid mihi tam multas laudando, Basse, puellas mutatum domina cogis abire mea? ${ }^{635}$

Por que, Basso, elogiando tantas outras moças, insistes para que eu abandone e substitua a minha amada?

Como diz Newman ${ }^{636}$, o seruitium amoris é uma condição humilhante que "não deve ser tomada como algo sério. Ela pressupõe uma circunstância específica, aquela que não é somente da elegia, mas do iambo, da sátira e da comédia: o simpósio."

Enquanto o amor elegíaco é singular, o iâmbico é plural quanto aos objetos da paixão. O poeta elegíaco, mesmo sem ser correspondido, uma vez que normalmente é preterido por um diues amator, conforma-se e compraz-se com a condição de

\footnotetext{
${ }^{632}$ Hor., Epod. 11.1-4 e 23-28.

633 Prop., 1.1, 27-32.

${ }^{634}$ Tradução de P. Martins.

${ }^{635}$ Prop. 1.4.1-2.

${ }^{636}$ Newman (1997:205).
} 
inaequalitas do cruel jogo de Amor. Ele tem convicção na fides a uma só amada, e sugere aos amigos que sigam o seu exemplo, sendo sempre constantes no amor:
vos remanete, quibus facili deus annuit aure, sitis et in tuto semper amore pares.
nam me nostra Venus noctes exercet amaras, et nullo vacuus tempore defit Amor.
hoc, moneo, vitate malum: sua quemque moretur cura, neque assueto mutet amore torum. quod si quis monitis tardas adverterit aures, heu referet quanto verba dolore mea! ${ }^{637}$
Vós, quem o deus atendeu com atenção, ficai, Sede sempre, no amor seguro, um par. Nossa Vênus trama contra mim amaras noites, O Amor ocioso não me falta nunca.
Meu mal, advirto, evitai: a cada um que a sua amada Aflija, e habituado ao amor, não o mude, Se, porém, derem ouvidos moucos aos meus conselhos $\mathrm{Ah}$ ! Com quanta dor hão de lembrar meus versos! $!^{638}$

Horácio, no epodo 11, faz o contrário, dizendo conseguir facilmente desvencilhar-se do seriutium amoris, e seu remédio são os vários amores que podem vir a ser.

\section{Os remedia amoris em epodos e elegias}

Observamos anteriormente várias passagens em que o amor é considerado como uma doença, um mal transmitido por Cupido, que em alguns casos pode ser fatal, como ocorre com Dido na Eneida. Especialmente os poetas elegíacos padecem desses males, porém uma de uma "infecção" mais amena que não chega a ser fatal, mas que parecer não ter cura. Eles referem-se aos remedia amoris considerando a maioria deles ineficaz. Propércio, num poema endereçado a Galo, propõe que um ombro amigo pode ser um paliativo para o seu mal, que ele garante não haver cura:

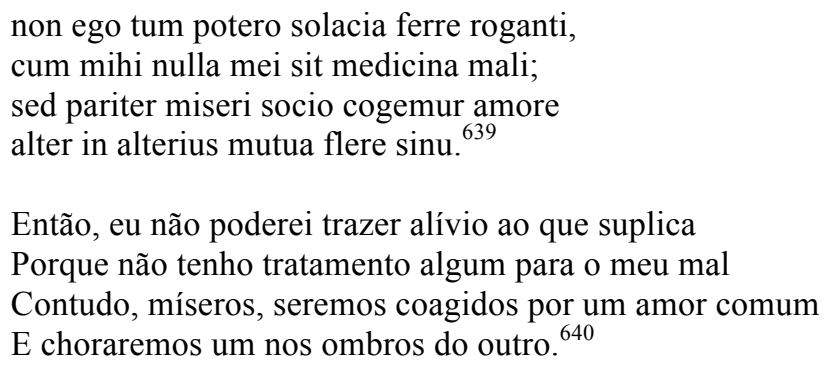

\footnotetext{
${ }^{637}$ Prop., 1.1.31-38.

${ }^{638}$ Tradução de P. Martins.

${ }^{639}$ Prop., 1.5.27-30.

${ }^{640}$ Tradução de P. Martins.
} 
No epodo 11, Horácio apresenta a tópica do amor como doença propondo modos de combatê-la. Aprisionado pelo amor por Licisco, ele fala de certos remédios que não lhe servem, os quais descarta, cada qual aludindo a tópicas comuns em outros gêneros poéticos. O primeiro é o conselho dos amigos, que é lugar-comum da elegia, e depois os graves insultos, verso que remete à elocução iâmbica. Por fim, Horácio apresenta um remédio que considera eficaz para curar o amor: um substituto, que pode ser moça ou moço. A relação com Licisco é desprovida de preocupação em resguardar a paritas e a fides. Horácio propõe a inconstância no caráter do amante, que sempre tem em vista um outro parceiro ou parceira. Essa passagem também é significativa na questão da recusa dos gêneros poéticos, pois é como se ele estivesse preterindo os universos elegíaco e iâmbico pelos temas líricos que futuramente iria desenvolver nas Odes. 


\section{Amor como deus tutelar da poesia erótica}

A interferência de uma divindade determinando ao poeta os rumos de sua produção não é novidade na poesia, como nota-se desde Homero, em que a Musa é invocada para cantar ou recontar a poesia épica. A partir do período helenístico, deuses como Dioniso $^{641}$, e especialmente Apolo, começam a figurar como divindades tutelares da poesia. Nesse sentido, uma passagem importante encontra-se nos Áitia de Calímaco $^{642}$, em que o poeta, respondendo às críticas dos Telquines, que o acusam por não ter escrito um poema longo sobre os reis, justifica sua escolha atribuindo a responsabilidade a um deus. Ele relata uma cena em que Apolo aparece e aconselha para que ele mantenha sua Musa leve e que conduza o seu carro para lugares inexplorados:

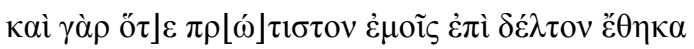

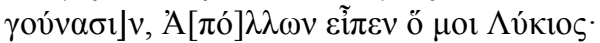

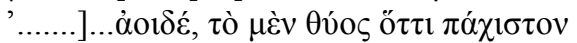

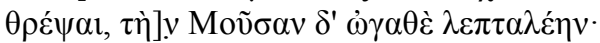

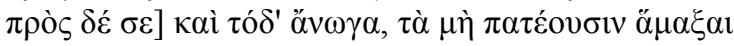

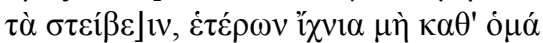

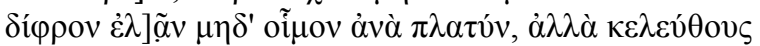

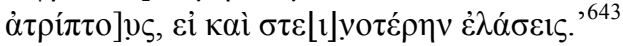

\footnotetext{
Na verdade, quando eu, em primeiro lugar, coloquei uma tábua sobre os meus joelhos, Apolo Lício me disse:

“.........] ó poeta, alimenta a vítima, tornando-a o mais gorda possível,

e a tua Musa delicada. Ainda te ordeno o seguinte: pisa por onde os carros não passam,

não conduzas o carro nem por caminhos comuns a outros, nem por um caminho largo, mas por caminhos não pisoteados, embora tu venhas a conduzi-lo por um caminho mais curto. ${ }^{644}$
}

Na poesia latina, é comum a intervenção dos deuses em poemas de recusa ${ }^{645}$, com a ideia de substituição de um gênero por outro. Nas Éclogas ${ }^{646}$ de Virgílio, Títiro diz que iria cantar proelia e reges, mas, por intervenção de Apolo, prefere a Musa Rústica. Especialmente em elegias eróticas augustanas, Cupido assume o papel normalmente atribuído a Apolo como deus que interfere nos rumos poesia. Ele torna-se ícone e veiculador de preceptivas como matéria, métrica e elocução. Além da

\footnotetext{
${ }^{641}$ Call., Ep. 7 e 8; Iamb. 1, fr. 191.7.ss.

${ }^{642}$ Call., Aet. 1-28.

${ }^{643}$ Call., Aet. 21-29.

${ }^{644}$ Tradução de G. B. Onelley.

${ }^{645}$ Prop. 1.7, 1.9, 2.1, 2.30a e b, 2.34, 3.1, 3.2 e 3.3; Ov., Am. 1.1, 2.1, 2.18 e 3.1.

${ }^{646}$ Virg., Ecl. 6.3-8
} 
mencionada passagem dos Áitia de Calímaco, outra fonte provável para essa tópica são os epigramas eróticos helenísticos ${ }^{647}$, dos quais já fornecemos vários exemplos, como aquele em que Meleagro ${ }^{648}$ diz que, apesar de ter sido incessantemente ferido, deixará letras falantes versando sobre a crueldade de Eros. O artifício da recusatio ${ }^{649}$ aparece em poemas latinos em que o poeta justifica a preferência por um gênero em detrimento de outro, normalmente mais elevado, por exemplo, elegia ou bucólica versus épica ou tragédia. O poeta justifica tanto a recusa como a preferência por determinada poesia, por exemplo: ele recusa alegando não poder escrever sobre determinados temas em obediência a desígnios divinos ou por falta de talento; e justifica as escolhas, alegando, entre as diversas razões, estar apaixonado e não conseguir pensar em outro objeto. A recusatio pode tomar a forma de uma cena dramática ou de uma breve narrativa sobre os motivos que levaram o poeta a fazer suas escolhas. Os poetas latinos, em boa parte dos poemas desse tipo, têm um interlocutor, normalmente um amigo de seu círculo, que é convidado a modificar o seu modo de escrever poesia.

\section{Cupido e seu opus nouum}

Na proposição da elegia 1.1, Ovídio diz que estava pronto para cantar os feitos das guerras violentas com o ritmo e o metro adequados, porém Cupido interpõe-se em seu caminho, mudando os rumos de sua poesia:

\footnotetext{
Arma gravi numero violentaque bella parabam edere, materia conveniente modis. par erat inferior versus - risisse Cupido dicitur atque unum surripuisse pedem.

'Quis tibi, saeve puer, dedit hoc in carmina iuris? Pieridum vates, non tua turba sumus. ${ }^{650}$

Preparava-me para armas e violentas guerras em ritmo grave cantar, sendo a matéria conveniente ao metro. $\mathrm{O}$ segundo verso era igual ao primeiro. Cupido riu conta-se - e roubou um pé.

"Cruel menino, quem te deu em poesia este direito?

Eu, poeta inspirado pelas Piérides, não sou da tua turma! ${ }^{651}$
}

O menino ri e rouba um pé métrico, tornando-se o agente desencadeador de um rompimento com os padrões da épica, que dá origem a um novo gênero poético, opus

\footnotetext{
${ }^{647}$ A.P. 5. 140, 179, 212; 12.56, 76, 101, 110 e 158.

${ }^{648}$ Meleagro, A.P. 5. 215.

${ }^{649}$ Para uma discussão sobre a recusatio, cf. Volk (2010:40-41).

${ }^{650}$ Ov., Am. 1.1.1-6.

${ }^{651}$ Tradução de J. A. Oliva Neto.
} 
nouum. Estabelece-se aí, certo parentesco, ou proximidade, entre os dois gêneros, como se a elegia fosse uma derivação da épica. Alusões também à matéria e à elocução elegíaca estão implícitos nesse poema em associação a Cupido: ao alterar a métrica, o deus transforma o modus do discurso, ou seja, o ritmo e a cadência, tornando-o mais leve, uma característica que define a elegia como o gênero apto para cantar o amor. Ovídio utiliza o discurso epidítico em vitupério e em louvor ao deus. Inicialmente, em uma inversão hierárquica, ele o vitupera como se fosse a própria Vênus punindo as travessuras do filho desobediente:

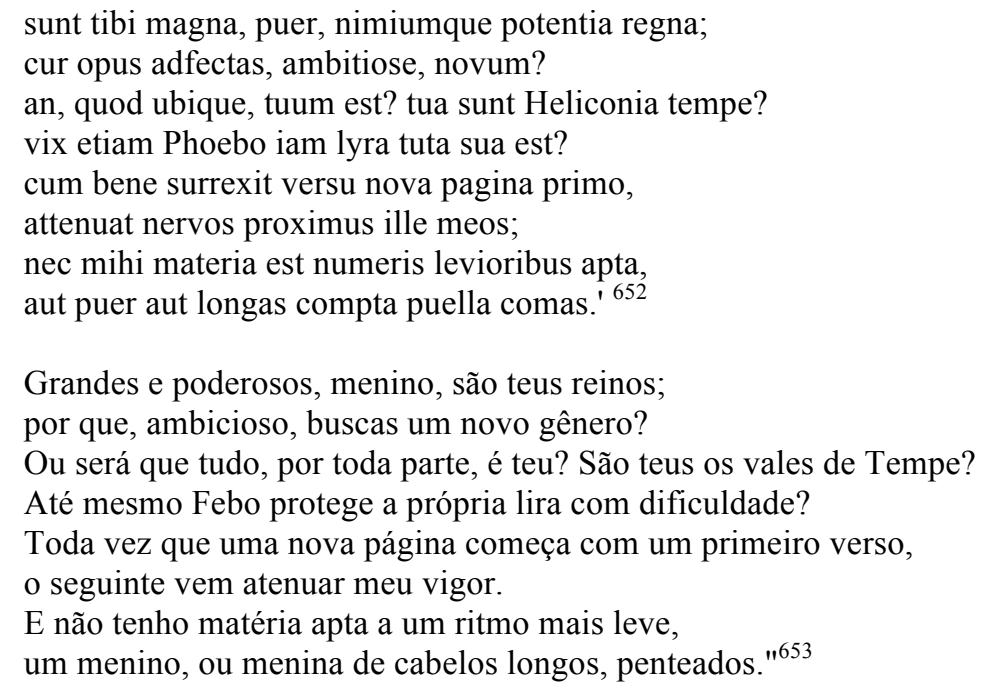

Ovídio refere-se à elegia como opus nouum. A palavra opus dá margem a diversas interpretações: ela pode referir-se à tópica de gênero, ou seja, à nova obra poética; ela também quer dizer obra militar, aludindo à tópica militia amoris; e, até mesmo, segundo Adams ${ }^{654}$, pode referir-se ao órgão sexual masculino, ideia reforçada pela proximidade com os verbos surgo e attenuo, que sugerem o processo de excitação e relaxamento no início e fim da relação sexual. Essa oscilação, ao mesmo tempo, remete à métrica do novo gênero, com a ideia de elevação do primeiro verso, o hexametro, e a atenuação do segundo, o pentâmetro. Para Ovídio, este é um modus perfeito para cantar sobre meninos ou meninas.

Após vituperar Cupido por sua traquinagem, o poeta exalta sua potência e supremacia, e evidencia os efeitos acarretados por essa força em sua persona, especialmente o comportamento vergonhoso que vira assunto na cidade:

saepe aliquis digito vatem designat euntem, atque ait "hic, hic est, quem ferus urit Amor!"

\footnotetext{
${ }^{652}$ Ov., Am. 1.1.14-20.

${ }^{653}$ Tradução de J. A. Oliva Neto.

${ }^{654}$ Opus e surgo, cf. Adams (2002:157 e 57)
} 
fabula, nec sentis, tota iactaris in urbe, dum tua praeterito facta pudore refers. tempus erat, thyrso pulsum graviore moveri; cessatum satis est - incipe maius opus! $!^{655}$

Amiúde alguém com o dedo aponta o poeta que passa, e diz: 'esse, esse aí é aquele a quem Amor feroz queima.' Já és, e não o sabes, anedota em toda a cidade, uma vez que, largado o pudor, contas teus feitos.

Era tempo de seres movido, impelido pelo tirso mais grave;

Basta de inércia! Dá início a um gênero mais alto. ${ }^{656}$

As ações do deus desencadeiam transformações que dão origem ao gênero que tem como uma de suas características principais a adoção de um único metro, o dístico elegíaco, também chamado de elegos ${ }^{657}$ pelos gregos antigos, que constitui-se de um hexâmetro datílico alternado com um hexâmetro duplamente catalético:

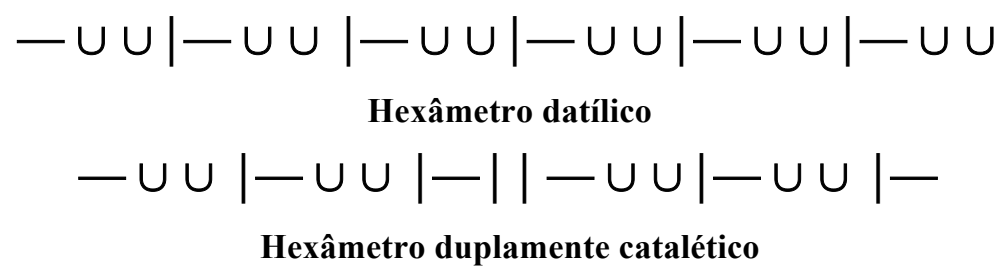

Ovídio evidencia o caráter cruel de Cupido, que atira suas setas, levando-o à perdição e, ao mesmo tempo, tornando-o apto a cantar esse novo gênero. O poeta expressa o lamento pelo páthos amoroso, e autointitula-se misero ${ }^{658}$, uma qualidade frequentemente atribuída à mulher vítima da paixão na poesia, como Dido, Fedra, ou Ariadne; porém, na elegia romana, esse papel é assumido pelo homem, o amante elegíaco, a quem o poeta normalmente dá voz em primeira pessoa. Ao ser atingido, ele queima, deixando que o deus reine ${ }^{659}$ em seu peito. Depois de toda a violência sofrida, o final do poema soa como uma rendição voluntária do poeta à ação de Cupido e aos versos elegíacos:

Questus eram, pharetra cum protinus ille soluta

legit in exitium spicula facta meum,

lunavitque genu sinuosum fortiter arcum,

'quod' que 'canas, vates, accipe' dixit 'opus!'

Me miserum! certas habuit puer ille sagittas.

uror, et in vacuo pectore regnat Amor.

\footnotetext{
${ }^{655}$ Ov., Am. 3.1.19-23.

${ }^{656}$ Tradução de J. A. Oliva Neto.

${ }^{657}$ Arist., Po. $1147 \mathrm{~b}$.

${ }^{658}$ Pichon (1991:203): Miserum: Exclamatio me miserum aut miseram saepissime apud nostros poetas occurrit, neque cum certa significatione.

${ }^{659}$ Pichon (1991:251): Regnum: modo Amoris aut Veneris in homines. Ov., Am. 1.26; Ov., Am. 1.8.42; 2.9.52-53.
} 
Sex mihi surgat opus numeris, in quinque residat:

ferrea cum vestris bella valete modis!

cingere litorea flaventia tempora myrto,

Musa, per undenos emodulanda pedes! ${ }^{660}$

Assim me queixara, quando Cupido, abrindo incontinente a aljava, apanhou flechas destinadas à minha perdição,

curvou com força o sinuoso arco no joelho

e disse: "toma aqui, poeta inspirado, um gênero para cantares.

Ai de mim!, o menino tinha certeiras setas!

Ardo e em meu peito, que era livre, reina Amor

Que minha obra comece com seis pés e se detenha em cinco!

Adeus, guerras cruéis e seus ritmos próprios!

Coroa-te, Musa, as louras têmporas com mirto ribeirinho,

tu que deves ser modulada com onze pés. ${ }^{661}$

\section{O certame entre Cupido e Apolo}

Especialmente em poemas de Ovídio, Tibulo e Propércio, Amor aparece como deus tutelar da poesia erótica, não apenas instruindo, como Apolo nos Áitia, mas, mais frequentemente, impondo ao poeta os preceitos de sua poesia.

No afresco abaixo, Cupidos vestem capas e guirlandas e posicionam-se ao redor da lira. Dois deles dedilham o instrumento, enquanto outro, mais acima, segura uma guirlanda maior. A guirlanda, além de fazer parte da indumentária do simpósio, contendo ervas cujos aromas acreditava-se que podiam atenuar a dor de cabeça causada pela bebida, é também um símbolo da glória do poeta. No Simpósio ${ }^{662}$, uma guirlanda de hera, violetas e laços da vitória é entregue por Alcibíades ao homenageado Agatão, o mais sábio e o mais belo dos poetas, ocasião em que cada um dos convivas apresenta um discurso sobre o amor.

\footnotetext{
${ }^{660}$ Ov., Am. 1.1.21-30.

661 Tradução de J. A. Oliva Neto.

${ }^{662}$ Platão, Sym. 212d-213b.
} 


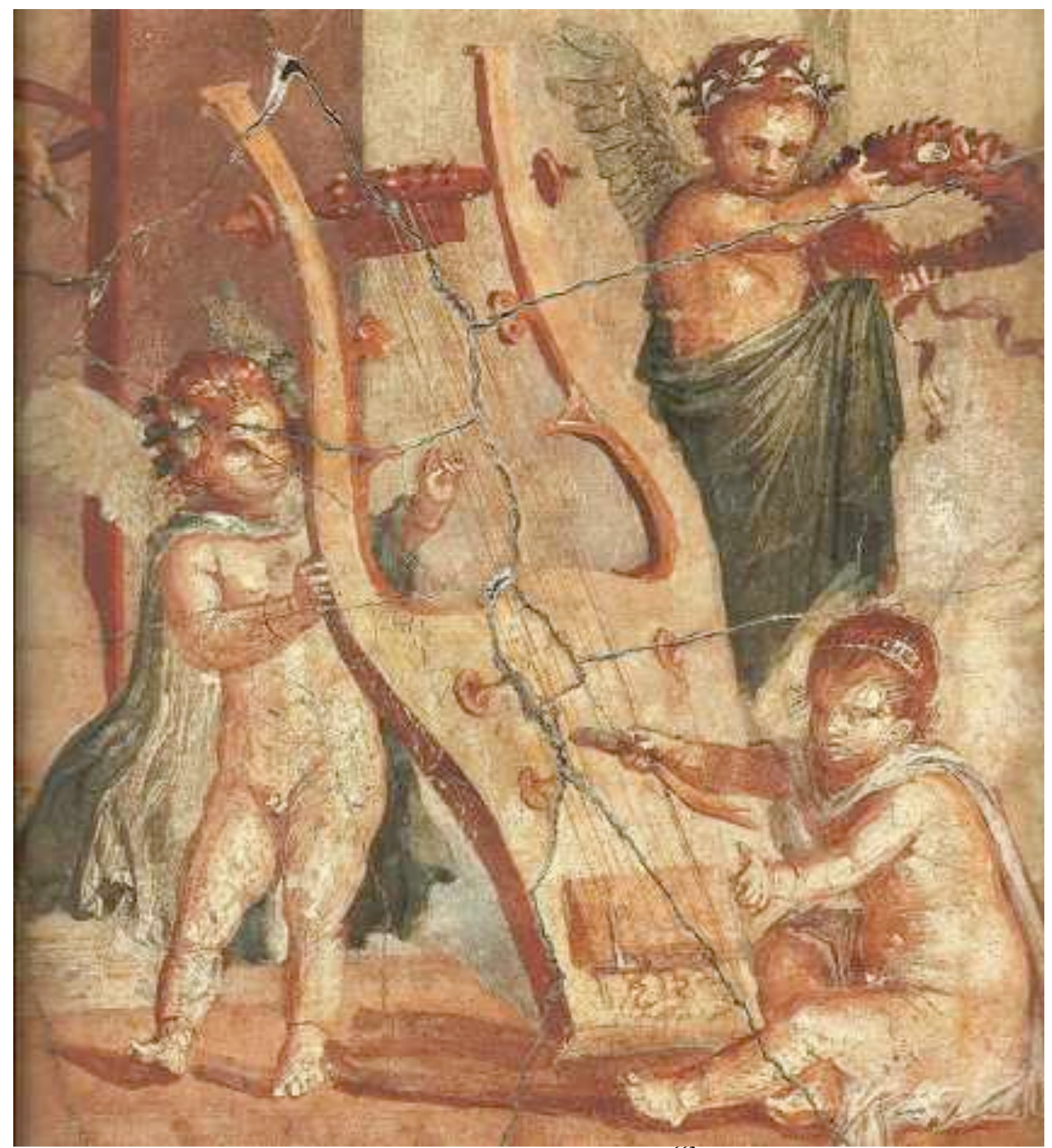

Figura 46. Amorini com cítara ${ }^{63}$

Em alguns poemas de recusatio, os poetas propõem um embate entre Apolo e Cupido pela supremacia em determinadas habilidades que lhe são características: ambos são hábeis no arco, e parece haver também uma disputa pela lira. Ovídio e Tibulo o fazem de maneira mais explícita, e Propércio de modo mais alusivo.

Em Amores 1.1, Ovídio sugere que Cupido tenha se apossado da lira de Apolo (vix etiam Phoebo iam lyra tuta sua est ${ }^{664}$ ), e, nas Metamorfoses, pormenoriza um embate motivado pelo poder do arco e flechas. O conflito é desencadeado quando Apolo, ao ver Cupido praticar com o arco, esbraveja que ele estaria usurpando seus

\footnotetext{
${ }^{663}$ Ercolano, insula V. Amorini con cetra. Afresco.

${ }^{664}$ Ov., Am. 1.1.23.
} 
poderes, e o desautoriza como intruso em artes que seriam inapropriadas para crianças. Apolo, além de humilhá-lo ainda vangloria-se de sua vitória sobe a Píton, atitude que desperta a ira e consequente vingança de Cupido, que o rebaixa, obrigando-o a abandonar sua usual arrogância. Fatham ${ }^{665}$ observa que, na disputa entre esses deuses, Ovídio, em vez de focalizar os feitos heroicos de Apolo, como a fundação do oráculo de Delfos, dá preferência ao tema de seu amor por Dafne, causado por Cupido. Ao sentirse afrontado, ele acerta o coração de Apolo, e complementa o ataque com uma flechada em Dafne, desta vez com uma seta de chumbo, que causa repulsa. Apolo passa a persegui-la incessantemente, enquanto ela sente aversão e foge:

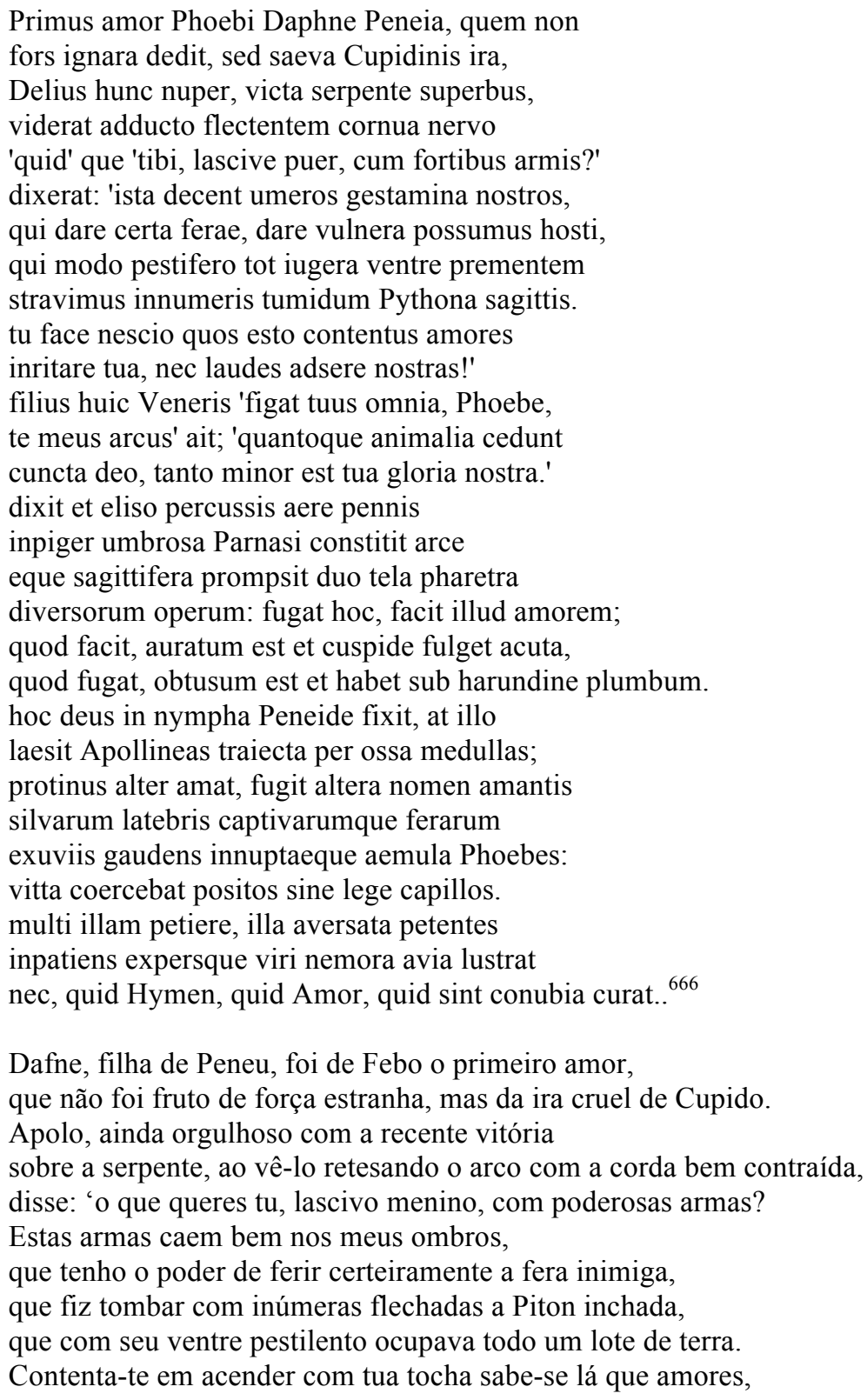

${ }^{665}$ Fatham (2004:122-123).

${ }^{666}$ Ov., Met. 1.452-480. 
e nem tenta tomar para si as minhas glórias!'

E o filho de Vênus, ouvindo isso, respondeu:

'Febo, teu arco pode atingir a todos, mas o meu te atingirá.

Tanto quanto os seres vivos são menos que os deuses,

menor é a tua glória que a minha'.

Disse isso, bateu asas e, rápido, cortando os ares,

pousou no cume sombrio do monte Parnaso,

e sacou da aljava duas setas de efeitos diversos:

uma incita a fuga, a outra desperta o amor;

a que desperta o amor é de ouro com ponta afiada e brilhante,

a que incita a fuga é obtusa e tem chumbo na ponta.

Esta última, o deus afixou na filha de Peneu, e com aquela

feriu Apolo, atravessando-lhe os ossos e a medula;

enquanto este ama de pronto, a outra foge ao nome do enamorado;

comprazendo-se com os covis nas matas e com despojos

de animais selvagens capturados; casta, êmula de Febe.

Uma fita amarrava suas mechas desgrenhadas.

Muitos a procuravam; mas ela, avessa a todos os pretendentes,

sem paciência para investidas e descomprometida de homem, vagava pelas remotas florestas, sem preocupar-se com o que possa ser Hímen, Amor ou casamento.

O orgulho épico de Apolo ao inquirir o lascivo menino alado lembra o de Ovídio em Amores 1.1, e o seu comportamento lamentoso assemelha-se ao da persona elegíaca. Armstrong ${ }^{667}$ observa que, com Apolo e Dafne, a paixão e o amor são introduzidos na épica de Ovídio, e a primazia de Cupido é declarada, enquanto a dignidade e autoridade dos outros deuses é minada. A experiência de Apolo simula a do poeta em Amores, e sua história também é programática; o poema pode ser épico, mas ao mesmo tempo é elegíaco. Apesar de elegíaco, preserva diferenças fundamentais: Dafne, embora bela e difícil, não é o modelo da amada elegíaca, especialmente porque é casta; a perseguição amorosa não se passa no cenário urbano da elegia, mas em ambiente selvagem. $\mathrm{O}$ fatídico amor causado por Cupido evidencia os limites entre o gênero elegíaco e os outros gêneros na obra: nas Metamorfoses, a lasciva elegia de Cupido é subordinada à épica de Apolo, enquanto a épica é atenuada pela forte presença elegíaca; sendo esse o modo de conciliação dos dois gêneros.

Tibulo também propõe uma disputa entre esses deuses, transferindo-a para um cenário bucólico. Vênus e Cupido mudam-se para o campo, adequando-se ao ambiente humilde:

Rura meam, Cornute, tenent villaeque puellam;

Ferreus est, heu, heu, quisquis in urbe manet.

Ipsa Venus latos iam nunc migravit in agros,

Verbaque aratoris rustica discit Amor. ${ }^{668}$

Cornuto, fazendas e casas de campo agora abrigam a minha amada;

$\mathrm{Ah}$ ! Triste é quem quer que permaneça na cidade.

\footnotetext{
${ }^{667}$ Armstrong (2005:142-143).

${ }^{668}$ Tib., 2.3.1-4.
} 
A própria Vênus já se mudou para os vastos campos,

e Amor está aprendendo a rústica linguagem do camponês.

Nesse contexto, Amor subjuga Apolo e o submete a uma servidão extremamente humilhante, atingindo-o com um mal que resiste às artes da cura:

Pavit et Admeti tauros formosus Apollo,

Nec cithara intonsae profueruntve comae,

Nec potuit curas sanare salubribus herbis:

Quicquid erat medicae, vicerat, artis, amor. ${ }^{669}$

O formoso Apolo alimentou os touros de Admeto,

não o ajudaram os cabelos intonsos e a cítara,

nem conseguia ele sanar as suas aflições com ervas salubres.

$\mathrm{O}$ amor venceu todas as artes da cura.

Após enumerar uma série de atividades servis que Apolo estaria desempenhando no campo ${ }^{670}$, com uma enfática interrogatio, ele eleva os humildes versos bucólicos de Amor em contraposição à poesia apolínea:

Delos ubi nunc, Phoebe, tua est, ubi Delphica Pytho?

Nempe Amor in parva te iubet esse casa. ${ }^{671}$

Onde está Delos agora, Febo? Onde está tua Délfica Pito?

Porque Amor ordena que vivas em uma choupana.

Na Ars Amatoria, o laureado Apolo, falando com a autoridade de um vate, aparece em epifania aconselhando Ovídio, o instrutor do lascivo Amor, a orientar os seus alunos a estudar o aforismo "conhece-te a ti mesmo" como maneira de ser bem sucedido no amor:

Haec ego cum canerem, subito manifestus Apollo

Movit inauratae pollice fila lyrae.

In manibus laurus, sacris inducta capillis

Laurus erat; vates ille videndus adit.

Is mihi 'Lascivi' dixit 'praeceptor Amoris,

Duc, age, discipulos ad mea templa tuos,

Est ubi diversum fama celebrata per orbem

Littera, cognosci quae sibi quemque iubet.

Qui sibi notus erit, solus sapienter amabit,

Atque opus ad vires exiget omne suas.

Cui faciem natura dedit, spectetur ab illa:

Cui color est, umero saepe patente cubet:

Qui sermone placet, taciturna silentia vitet:

Qui canit arte, canat; qui bibit arte, bibat.

Sed neque declament medio sermone diserti,

\footnotetext{
${ }^{669}$ Tib., 2.3.11-14.

${ }^{670}$ Tib., 2.3.14-22

${ }^{671}$ Tib., 2.3.27-28.
} 
Nec sua non sanus scripta poeta legat!'

Sic monuit Phoebus: Phoebo parete monenti;

Certa dei sacro est huius in ore fides. ${ }^{672}$

Quando eu assim cantava, subitamente Apolo manifestou-se

e dedilhou com o polegar as cordas de sua áurea lira.

Nas mãos o louro, com louro sua sagrada coma

estava coberta; ele se aproxima, um vate para ser visto.

Ele me disse: "Preceptor do lascivo Amor,

vem trazer teus discípulos ao meu templo,

onde há uma frase, cuja fama se espalha por todo o orbe,

que ordena que cada um conheça a si próprio.

Somente aquele que conhecer a si próprio amará sabiamente,

e concluirá sua obra de acordo com suas próprias forças.

Aquele a quem a natureza concedeu beleza, que seja admirado;

aquele que tem bela cor, que repouse sempre com o ombro à mostra:

aquele a quem agrada discursar, que evite o silêncio taciturno:

quem canta com arte, que cante; quem bebe com arte, que beba.

Porém, que nunca um discurso seja declamado em meio à discussões,

e nem o poeta recite seus versos insano".

Assim aconselhou Febo: observe os conselhos de Febo.

É digna de crédito a fidelidade na boca sagrada desse deus.

\section{O lascivo Amor no embate entre a Tragédia e a Elegia}

Amores 3.1 é uma recusatio que consiste na dramatização de um embate verbal entre as personificações ${ }^{673}$ da Tragédia e da Elegia, que disputam a preferência do poeta. O poeta situa esse agón em um bosque sagrado, narrando o desenrolar dos acontecimentos como testemunha ocular: diz que estava ali procurando uma Musa que o inspirasse a compor, quando avista as duas personificações. A princípio, sem ser notado, ele as observa: a Elegia é mulher bela, com face de amante, com tênues vestes e com um pé mais longo que o outro. Tais atributos correspondem, respectivamente, aos contornos do gênero elegíaco quanto à matéria, à elocução e à métrica. A impetuosa Tragédia, por sua vez, veste um manto, coturnos e carrega um cetro nas mãos, atributos que remetem à elevação do gênero. Nesse certame, às duas personificações são atribuídas falas que fornecem referências quanto ao decoro desses dois gêneros. Elas, inicialmente, dirigem-se ao poeta, começando com a Tragédia ${ }^{674}$ e depois a Elegia ${ }^{675}$. A Tragédia invectiva o poeta e sua produção, dizendo que ele é motivo de comentários pela cidade, e tenta persuadi-lo a iniciar uma obra mais elevada:

\footnotetext{
${ }^{672}$ Ov., Ars 2.493-510.

${ }^{673}$ Lausberg (2004:251): Uma variante de realização da alegoria é a personificação, que consiste na introdução de coisas concretas, assim como de noções abstratas e coletivas como pessoas que aparecem a falar e a agir.

${ }^{674}$ Ov., Am. 3.15-31.

${ }^{675}$ Ov., Am. 3. 36-61.
} 
saepe aliquis digito vatem designat euntem, atque ait "hic, hic est, quem ferus urit Amor!" fabula, nec sentis, tota iactaris in urbe, dum tua praeterito facta pudore refers. tempus erat, thyrso pulsum graviore moveri; cessatum satis est - incipe maius opus! $!^{676}$

Amiúde alguém com o dedo aponta o poeta que passa, e diz: 'esse, esse aí é aquele a quem Amor feroz queima.' Já és, e não o sabes, anedota em toda a cidade, uma vez que, largado o pudor, contas teus feitos.

Era tempo de seres movido, impelido pelo tirso mais grave; Basta de inércia! Dá início a um gênero mais alto. ${ }^{677}$

A Tragédia e a Elegia personificadas evidenciam referências à elocução de cada um desses gêneros: a Elegia é tênue, leve e breve ${ }^{678}$; a Tragédia é violenta, enérgica, grave, dura e longa ${ }^{679}$. As ações também aludem à elocução: a Elegia sorri com os olhos, brinca ${ }^{680}$ e se diz alcoviteira de Vênus, evidenciando os aspectos lúdico, cômico e invectivo do gênero. Cupido, a quem ela chama de mea cura, é tênue ${ }^{681}$ e ligeiro, como ela própria ${ }^{682}$. Com uma exclamatio, ela revela seus atributos:

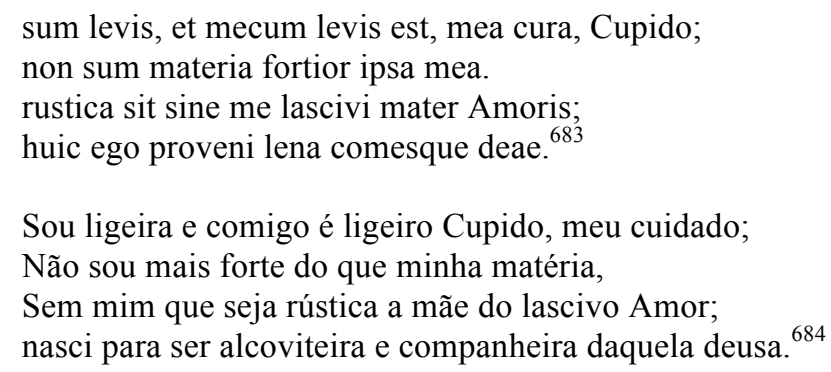

Vênus é mãe do lascivo ${ }^{685}$ Amor. A lascívia é um termo que pode ter várias acepções. Primeiramente, na forma adjetiva, encaixa-se perfeitamente à persona de um deus criança, já que pode significar brincalhão, petulante, divertido e de caráter vivo. Um outro sentido recorrente associa-se ao desejo sexual e à ausência de pudor, ou seja, certa falta de controle da libido. No entanto, poderíamos considerar aqui, ainda, um outro sentido para o termo lasciuus nos poemas, considerando-se sua aplicação à questão dos gêneros poéticos. Quintiliano qualifica Ovídio duas vezes com este atributo.

\footnotetext{
${ }^{676}$ Ov., Am. 3.1.19-24.

${ }^{677}$ Tradução de J. A. Oliva Neto.

${ }^{678}$ Tenuis: 9; tener: 27 ; leuis: 41 ; breuis: $66,68$.

${ }^{679}$ Violenta, 11; fortis: 42; grauis, 23, 36, 42, dura: 46, 53; longa, 66.

${ }^{680}$ Subrisit: 42; ludit: 27.

${ }^{681}$ Tib., 1.4.9; Ov., Am. 3.1.69; Ov., Am. 3.15.1.

${ }^{682}$ Ov., Am. 2.9b.47;

${ }^{683}$ Ov., Am. 3.1.41-44.

${ }^{684}$ Tradução de J. A. Oliva Neto.

${ }^{685}$ Pichon, (1991:184): Lasciuia: significat simul uoluptatem et impudentem liberamque audaciam. Sic lasciuus dicitur Amor, qui nihil reueretur. Tib. 1.10.61; Prop. 2.24, 7.
} 
Uma vez, na conhecida passagem sobre os elegíacos augustanos e seus atributos, em que ele coloca a lascívia de Ovídio em contraposição à elegância e à dureza de outros:

Elegia quoque Graecos prouocamus, cuius mihi tersus atque elegans maxime uidetur auctor Tibullus. Sunt qui Propertium malint. Ouidius utroque lasciuior, sicut durior Gallus.

Também rivalizamos com os gregos na elegia, cujo autor mais elegante considero Tibulo. Há quem prefira Propércio. Ovídio é o mais lascivo, enquanto Galo, o mais grave.

A associação mais imediata que fazemos ao termo lasciuus refere-se à matéria erótica, predominante na obra de Ovídio; porém outra passagem de Quintiliano sobre esse poeta e as suas Metamorfoses ${ }^{686}$, leva a outro sentido de lascívia, referente à unidade da obra:

Ouidius lasciuire in Metamorphosesin solet; quem tamen excusare necessitas potest, res diuersissimas in speciem unius corporis colligentem. ${ }^{687}$

Ovídio costuma ser artificioso nas Metamorfoses; porém a necessidade de coligir as mais diversas matérias sob a aparência de um só corpo pode desculpá-lo. ${ }^{68}$

Ovídio foi artificioso, ou lascivo, porque ousou coligir as mais diversas matérias em um único corpo. Desse modo, é possível que a lascívia, ou "promiscuidade", de Ovídio nas Metamorfoses, seja uma referência à poikilia em sua obra, ou seja, a presença de atributos de diversos gêneros em sua obra hexamétrica, propondo uma unidade diversa daquela aristotélica.

Ovídio usa um jogo de palavras envolvendo o verbo mоиeo, relacionado aos afetos: no início do poema, ele diz que procurava por uma Musa que o movesse, porém, ao final, é a Musa da Tragédia quem se comove. Ovídio, dirigindo-se à Tragédia, a recusa e a convence a dar lugar à Elegia, que é breve, enquanto ela, labor aeternus, deve esperar. Como é comum na recusatio, o poeta convida a Tragédia a modificar-se, acrescentando versos breves aos longos; e por fim, apela para que os Amores se apressem, enfatizando ainda mais o caráter veloz da elegia, e o movimento de transição para outros gêneros:

Desierat. coepi: 'per vos utramque rogamus, in vacuas aures verba timentis eant. altera me sceptro decoras altoque cothurno; iam nunc contacto magnus in ore sonus. altera das nostro victurum nomen amori ergo ades et longis versibus adde brevis!

\footnotetext{
${ }^{686}$ Agradeço a indicação do Professor João A. Oliva Neto pela indicação desta passagem de Quintiliano (Quint., Inst. Or. 4.1.77-78), e pela discussão sobre o termo lasciuus, em curso de pós-graduação, que chamou atenção para a acepção da palavra aplicada à questão dos gêneros poéticos.

${ }^{687}$ Quint., Inst. Or. 4.1.77-78.

${ }^{688}$ Tradução de J. A. Oliva Neto.
} 
exiguum vati concede, Tragoedia, tempus!

tu labor aeternus; quod petit illa, breve est.'

Mota dedit veniam - teneri properentur Amores,

dum vacat; a tergo grandius urguet opus! ${ }^{689}$

Terminara. Comecei: "peço a cada uma de vós

que as palavras de quem teme cheguem a ouvidos disponíveis.

Tu me ornas com teu cetro e teu grande coturno:

tocada já por ti minha boca, a voz agora é grandiosa,

tu dás ao meu amor um nome sempre vivo.

Vem, pois, e aos longos acrescenta versos breves!

Ao vate, Tragédia, concede um pouco de tempo.

Tu és trabalho eterno: o que a Elegia pede é breve".

Comovida, permitiu. Que, ternos, meus Amores se apressem,

enquanto é lícito, que lá detrás um gênero mais elevado já me alcança. ${ }^{690}$

\section{Amor como praeceptor}

Como deus tutelar da poesia erótica, Amor ensina os preceitos dessa arte ao poeta. Propércio absorve os ensinamentos de maneira rápida e sofrida, transformando-se também em um praeceptor amoris tal qual o deus. Propércio, em algumas recusationes, sob a tutela de Amor, transfere esse conhecimento a outros amigos poetas, tentando convencê-los a aderir à poesia erótica, entre eles, Pôntico com sua épica e Linceu com sua filosofia.

Ao longo dos livros 1 e 2, Propércio evidencia as lições e o consequente resultado do aprendizado, que é a final perpetuação de sua poesia erótica com a coroação no simpósio e o triunfo. Seguindo o procedimento da recusatio, ele não atribui à sua própria vontade a recusa da poesia elevada em favor da elegia, mas justifica-se dizendo que é vítima das flechadas de Amor, que o coage a adequar-se às leis do simpósio e a cantar temas suaves e agradáveis à docta puella, Cíntia, a escolhida para ser o objeto único da poesia.

Propércio inicia o Livro 1 evidenciando a violência de Amor ao coagi-lo a escrever versos eróticos em louvor à beleza de Cíntia. As relações entre esses personagens movem-se como num triângulo: Cupido ao topo no comando, Cíntia no papel de heroína e Musa singular dos poemas, e o poeta no papel de escravo, condenado a acatar as ordens do deus. Nesse sentido, Amor tem dois papéis fundamentais como deus tutelar da poesia erótica de Propércio: age como vetor de afecções que determinam

\footnotetext{
${ }^{689}$ Ov., Am. 3.1.61-70.

${ }^{690}$ Tradução de J. A. Oliva Neto.
} 
o comportamento do poeta e como guardião ${ }^{691}$ da Musa elegíaca. Na elegia 1.1, Amor aparece como praeceptor do poeta, ensinando-o a odiar castas meninas e a agir de modo irresponsável. Na elegia 1.7, é Pôntico quem está sob a mira do deus. Propércio lança advertências sobre o destino patético que espera o amigo, caso seja atingido. Propércio, que aprendeu as lições de Amor logo no início, agora tenta ensinar o caminho a ser percorrido, enfatizando os perigos de dedicar-se tardiamente a esse tipo de poesia, e alertando o amigo sobre as terríveis consequências que podem abatê-lo:

Dum tibi Cadmeae dicuntur, Pontice, Thebae armaque fraternae tristia militiae, atque, ita sim felix, primo contendis Homero (sint modo fata tuis mollia carminibus), nos, ut consuêmus, nostros agitamus amores, atque aliquid duram quaerimus in dominam; nec tantum ingenio quantum servire dolori cogor et aetatis tempora dura queri.

hic mihi conteritur vitae modus, haec mea famast, hinc cupio nomen carminis ire mei. me laudent doctae solum placuisse puellae, Pontice, et iniustas saepe tulisse minas; me legat assidue post haec neglectus amator, et prosint illi cognita nostra mala. (14) [nec poterunt iuvenes nostro reticere sepulcro (23) 'ardoris nostri magne poeta iaces.'] (24) te quoque si certo puer hic concusserit arcu - (15) quo nollem nostros me violasse deos! longe castra tibi, longe miser agmina septem flebis in aeterno surda iacere situ; et frustra cupies mollem componere versum, nec tibi subiciet carmina serus Amor. tum me non humilem mirabere saepe poetam, tunc ego Romanis praeferar ingeniis. tu cave nostra tuo contemnas carmina fastu: saepe venit magno faenore tardus Amor. ${ }^{692}$

Enquanto tu, Pôntico, cantas sobre Tebas de Cadmo e as funestas armas da guerra entre irmãos, e ainda emulas o excelente Homero, que eu assim seja feliz (espero que teus poemas tenham somente suaves destinos). Eu, como de costume, ocupo-me dos amores, e ainda procuro algo contra minha cruel amada. Sou coagido a servir nem tanto ao engenho quanto à dor e a lamentar os duros tempos da juventude. Desse modo minha vida se consome, esta é minha fama, daqui eu desejo que se espalhe a glória de minha poesia. Que me louvem por eu ter somente agradado à douta menina, Pôntico, e por ter com frequência suportado injustas ameaças. Que, depois de tudo, o amante desprezado leia-me assiduamente, e que lhe seja útil ter conhecido os meus males.

E os jovens não conseguirão conter as palavras diante de meu sepulcro: "jazes aqui, grande poeta de nosso ardor!"

${ }^{691}$ Prop., 2.30a.

${ }^{692}$ Prop., 1.7.15-20. 
Também, se este menino feri-lo com seu certeiro arco, -

com o qual eu não gostaria que nossos deuses tivessem me atingido! longe de ti os acampamentos, longe os sete exércitos, infeliz,

lamentarás que eles descansem silenciosos sob a terra para sempre;

e, em vão, desejarás compor suave verso;

e nem Amor, se tardio, te sugerirá poemas.

Então, muitas vezes, me admirarás como poeta não humilde,

e eu serei o preferido entre os romanos de engenho.

Evita desprezar meus poemas com tua arrogância;

Amor, se chega tarde, amiúde cobra altos juros.

As previsões efetuadas por Propércio na 1.7 concretizam-se na 1.9: Pôntico cai presa dos Amores, iniciando um processo de aprendizado e adequação, semelhante ao de Propércio, porém sofrendo extremo rebaixamento de status, ao ficar submetido ao seruitium amoris em circunstâncias ainda mais humilhantes, apaixonando-se por uma escrava:

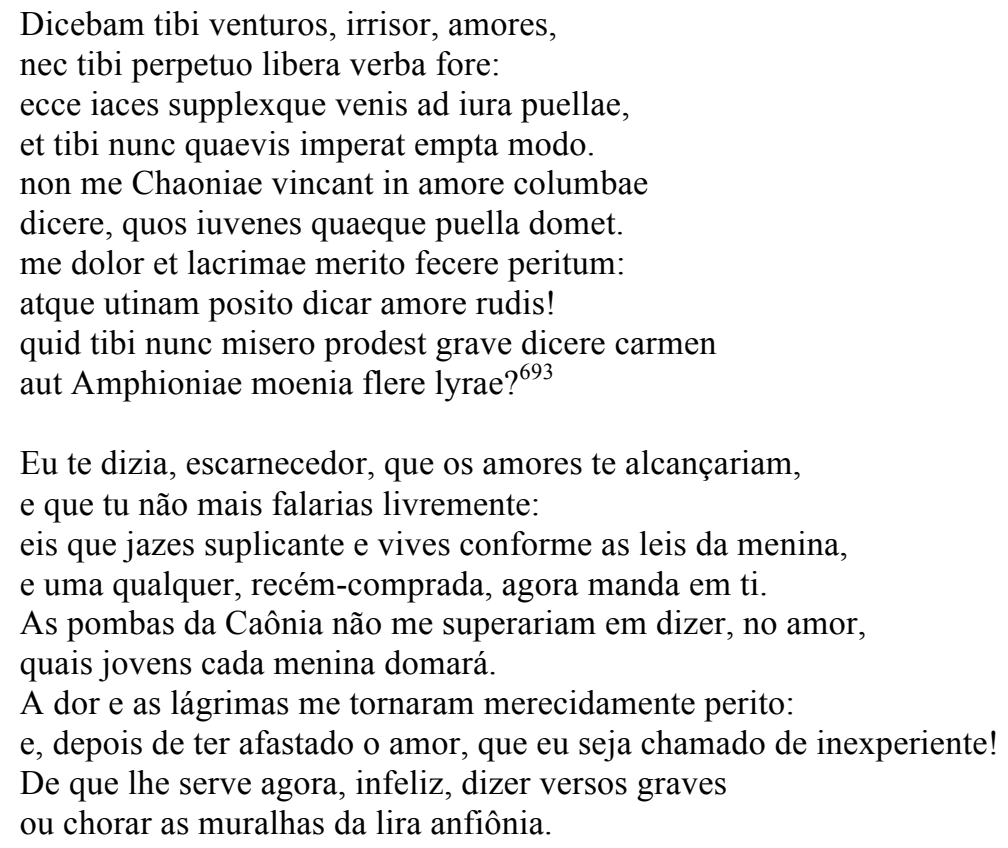

Amor é mencionado três vezes em associação às novas preceptivas da poesia de Pôntico. Propércio evidencia aspectos elocutivos da elegia contrastando os versos de Mimnermo, conhecido como inventor da elegia, à obra de Homero, ícone da épica heroica. Ele ensina ao amigo que a poesia produzida sob os auspícios do dócil Amor deve ser suave em oposição à gravidade da épica:

plus in amore valet Mimnermi versus Homero: carmina mansuetus lenia quaerit Amor. i quaeso et tristis istos sepone libellos, et cane quod quaevis nosse puella velit!

${ }^{693}$ Prop., 1.9.1-10. 
quid si non esset facilis tibi copia! nunc tu insanus medio flumine quaeris aquam.

necdum etiam palles, vero nec tangeris igni: haec est venturi prima favilla mali.

tum magis Armenias cupies accedere tigres

et magis infernae vincula nosse rotae,

quam pueri totiens arcum sentire medullis

et nihil iratae posse negare tuae.

nullus Amor cuiquam facilis ita praebuit alas,

ut non alterna presserit ille manu. ${ }^{69}$

No amor, mais vale o verso de Mimnermo do que Homero:

o dócil Amor deseja suaves poemas.

Vai, te peço, deixa de lado estes tristes livrinhos,

e canta aquilo que a menina quer conhecer!

O que seria, se tu não tivesses recursos fáceis! Agora tu,

insano, procuras água no meio do rio.

Nem mesmo ainda estás pálido, e tampouco foste tocado pelo verdadeiro fogo:

esta é a primeira fagulha do mal que há de chegar.

Então preferirás aproximar-se dos triges da Armênia,

e conhecer os grilhões da roda infernal,

do que sentir o arco do menino incessantemente nas entranhas,

e nada poder negar à tua amada enfurecida.

Nenhum Amor ofereceu ligeiras asas a alguém,

sem que o pressionasse com mão alternada.

Pôntico, assim como Propércio na elegia 1.1, é subjugado pelos Amores e será obrigado a manter os olhos fixos em uma única puella:

nec te decipiat, quod sit satis illa parata:

acrius illa subit, Pontice, si qua tuast,

quippe ubi non liceat vacuos seducere ocellos,

nec vigilare alio limine cedat Amor.

qui non ante patet, donec manus attigit ossa:

quisquis es, assiduas tu fuge blanditias!

illis et silices et possint cedere quercus,

nedum tu possis, spiritus iste levis.

quare, si pudor est, quam primum errata fatere:

dicere quo pereas saepe in amore levat. ${ }^{695}$

Nem se deixe enganar, ao pensar que ela é muito preparada:

ela avança com mais violência, Pôntico, se for tua.

Certamente, quando não for possível desviar os olhinhos livres,

e Amor não permitir que vigies outras portas.

Ele nunca se revela, antes que suas mãos atinjam os ossos:

quem quer que sejas, evita frequentes carícias!

Carvalhos e rochas podem não resistir a elas,

menos ainda podes tu, este espírito leve.

Por isso, se há pudor, reconhece os erros quanto antes,

dizer a causa do sofrimento, amiúde, no amor, conforta.

Discutimos anteriormente a figuração de Amor como custos. Na questão do gênero, ele tem papel fundamental na determinação do objeto da poesia: como guardião

${ }^{694}$ Prop., $1.9 .11-24$.
${ }^{695}$ Prop., $1.9 .25-34$. 
de Cíntia, ele garante que Propércio só tenha olhos para ela, mantendo-a como heroína e Musa singular das elegias. Como observamos anteriormente, o jogo de dominação do olhar e pelo olhar é um de seus principais artifícios. Na elegia 2.2, o deus cria ilusões para salientar ainda mais a beleza da amada:

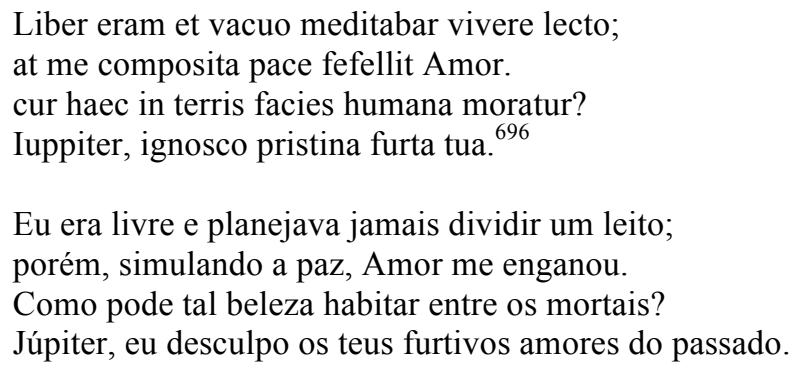

Ludibriado por Amor, o poeta só tem olhos para essa mulher de longas comas esvoaçantes, bela e elegante com suas vestes de Cós: sua beleza ultrapassa a das deusas $^{697}$; ela é uma segunda Helena ${ }^{698}$; ela é quem o move para escrever suas longas Ilíadas $^{699}$. Como diz Stahl ${ }^{700}$, "Cíntia é a encarnação de tudo aquilo que o amor pode fazer pelo poeta”. Enfim, o poeta realizará os combates de Vênus e Cupido, até morrer heroicamente, obtendo assim a fama e a glória almejadas ${ }^{701}$. Como diz Newman ${ }^{702}$ o poeta elegíaco, no amor, “exerce todas as grandes virtudes da vida pública romana no fórum e no campo de batalha: fides, constantia, grauitas e até mesmo vigilantia."

A partir da elegia 2.10 evidencia-se uma modificação no tratamento da matéria erótica, a qual, embora permaneça central ao longo de todo o livro 2, adquire novas perspectivas, que já foram discutidas por autores, como Lyne ${ }^{703}$, Tatum ${ }^{704}$, Maria Wyke e Paulo Martins ${ }^{705}$. Esse poema é um raro exemplo de recusatio invertida, em que Propércio simula uma recusa da elegia em favor da épica. Nos versos iniciais, ele sugere uma expectativa de ascender ao Hélicon $^{706}$, o que significaria elevar a sua poesia ao nível da épica, abandonando os temas eróticos da juventude e dando preferência àqueles

\footnotetext{
${ }^{696}$ Prop., 2.2.1-4.

${ }^{697}$ Prop., 2.2.13.

${ }^{698}$ Prop., 2.3.32.

699 Prop., 2.1.14.

700 Stahl (1985).

${ }^{701}$ Prop.,2.1.47.

${ }^{702}$ Newman (1997:393).

${ }^{703}$ Lyne (1988).

${ }^{704}$ Tatum (2010).

${ }^{705}$ Martins (2011).

${ }^{706}$ De acordo com Tatum (2000:399): “A iniciação do poeta pelas Musas no monte Helicon, que se deve à apropriação de Calímaco da ideia de Hesíodo, é uma convenção literária alexandrina fundamental, assim com o (também antigo) emprego das fontes e rios como símbolos de inspiração poética". Esses versos reverberam: Virg. Ecl.
} 
mais adequados ao seu êthos de poeta maduro: aetas prima canat Veneres, extrema tumultus $^{707}$ (Na juventude cantam-se os Amores, na maturidade o conflito). No entanto, Amor aparece ao final do poema à margem do rio Permesso ${ }^{708}$ e ali banha os poemas de Propércio, prorrogando o momento de sua ascensão, com a permanência no sopé do Monte Hélicon, onde continua cantando os temas mais humildes e tênues de suas elegias:

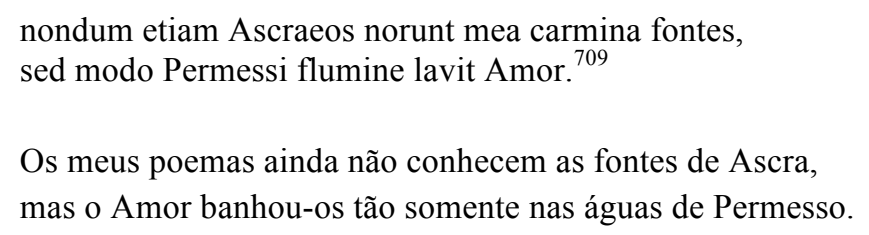

Esses versos reverberam a passagem da Teogonia em que as Musas banham-se no Permesso antes da ascensão ao Hélicon, com a diferença que nesta elegia os poemas de Propércio é que são lavados por Amor antes da pretensa ascensão.

A elegia 2.12, sobre a pintura do Amor menino, que discutimos anteriormente, é considerada como poema que marca uma transição ${ }^{710}$, seja para uma segunda parte, seja como poema de abertura de um terceiro livro ${ }^{711}$. Nessa elegia, Amor é objeto do poema, e a matéria erótica é apresentada com uma preocupação maior com os afetos dos amantes e do poeta, do que com Cíntia especificamente. Na elegia seguinte, o deus arqueiro reaparece no papel de inimigo implacável, comparado a um temível e feroz guerreiro Aquemênida, que habilmente trespassa o poeta com suas incontáveis flechas, e ordena que ele transporte-se com Cíntia para o bosque de Ascra, lugar das Musas hesiódicas, indicando o movimento em direção a um gênero mais elevado:

\footnotetext{
Non tot Achaemeniis armantur Susa sagittis, spicula quot nostro pectore fixit Amor. hic me tam gracilis vetuit contemnere Musas, ussit et Ascraeum sic habitare nemus, non ut Pieriae quercus mea verba sequantur, aut possim Ismaria ducere valle feras, sed magis ut nostro stupefiat Cynthia versu: tunc ego sim Inachio notior arte Lino. ${ }^{712}$

Nem mesmo Susa está armado com tantas setas Aquemênidas quantas Amor cravou em meu peito.

Ele proibiu que eu contrariasse as graciosas Musas, e ordenou que eu habitasse neste bosque de Ascra.

Não espero que os carvalhos piérios sigam as minhas palavras,
}

\footnotetext{
${ }^{707}$ Prop., 2.10.7.

${ }^{708}$ Virg., Ecl. 6.64-ss., imagem de Gallo no rio Permesso,

${ }^{709}$ Prop., 2.10.25-26.

${ }^{710}$ Lyne (1998); Tatum (2000).

${ }^{711}$ Martins (2012).

${ }^{712}$ Prop., 1.13.1-8.
} 
ou que eu possa conduzir as feras pelo vale Ismário, mas, para mim, mais vale que Cíntia encante-se com os meus versos: com esta arte eu ficaria mais famoso do que Lino de Argos.

$\mathrm{Na}$ elegia 2.34, Propércio encerra o programa poético dos Livros 1 e 2 triunfando com sua elegia erótica. Considerando uma divisão do poema em três seções ${ }^{713}$, podemos resumi-las em: $\mathrm{I}^{714}$ : Linceu, destinatário do poema, apaixona-se por Cíntia, e é censurado pelo seu comportamento; $\mathrm{II}^{715}$ : Linceu apaixona-se por outra, e Propércio, como praeceptor amoris, o ensina sobre a nova poesia; III: Propércio procura legitimar o valor de sua obra, comparando-a com a de Virgílio ${ }^{716}$, e elevar sua persona como poeta, incluindo-se em uma genealogia de autores ${ }^{717}$. Amor aparece no início de cada uma dessas seções, sendo identificado na primeira parte por suas ações: Amor, aquele deus que destrói amizades e promove guerras ${ }^{718}$; na segunda parte, pelas afecções que causa: o "nosso deus" ${ }^{\text {719 }}$ que desperta a insânia; e na terceira parte, por sua imago e pelo seu ambiente: o deus arqueiro de mira inequívoca que atua durante os simpósios. Inicialmente, Propércio, como praeceptor amoris, questiona os perigos de confiar a amada a Amor:

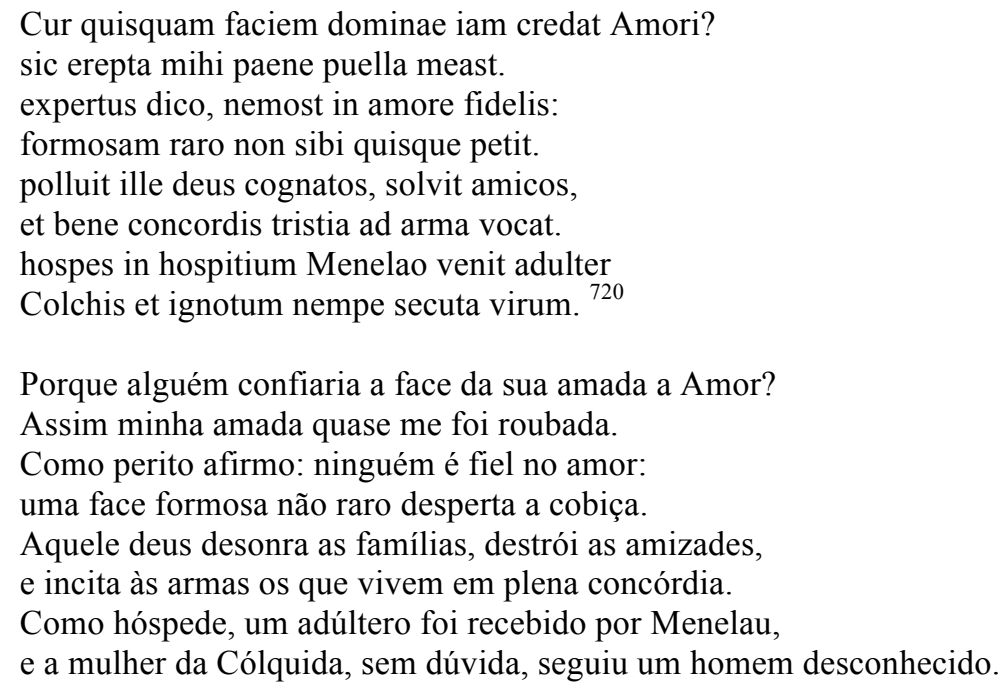

Ele imputa a Linceu a tentativa de um grave crime, que poderia resultar em uma guerra como a de Tróia; porém, ironicamente, logo desculpa o amigo, atribuindo a responsabilidade a Amor. Na Ilíada, Páris, o adúltero por excelência, e Helena, são

\footnotetext{
${ }^{713}$ Divisão do poema, cf. Stahl (1985:187-188); Heyworth (2007:264-280); Fedelli (2005:952).

${ }^{714}$ Prop. 2.34.1-24.

715 Prop. 2.34.25-58.

${ }^{716}$ Prop. 2.34.59-80.

${ }^{717}$ Prop. 2.34.81-94.

${ }^{718}$ Prop. 2.34.5-6.

${ }^{719}$ Prop. 2.34. Prop. 2.34 .

${ }^{720}$ Prop., 2.34.1-8.
} 
vítimas das tramas de Vênus; nos versos de Propércio, Cupido, o inseparável filho da deusa, é apontado como causador desse amor épico.

Na pintura abaixo, observa-se o tema do encontro de Páris e Helena ${ }^{721}$. Cupido se entrepõe entre os amantes, posicionado diante de uma porta alta e entreaberta, em um nicho entre duas colunas. Ele olha para Helena, que está em pé, enquanto aponta o dedo para Páris, sentado:

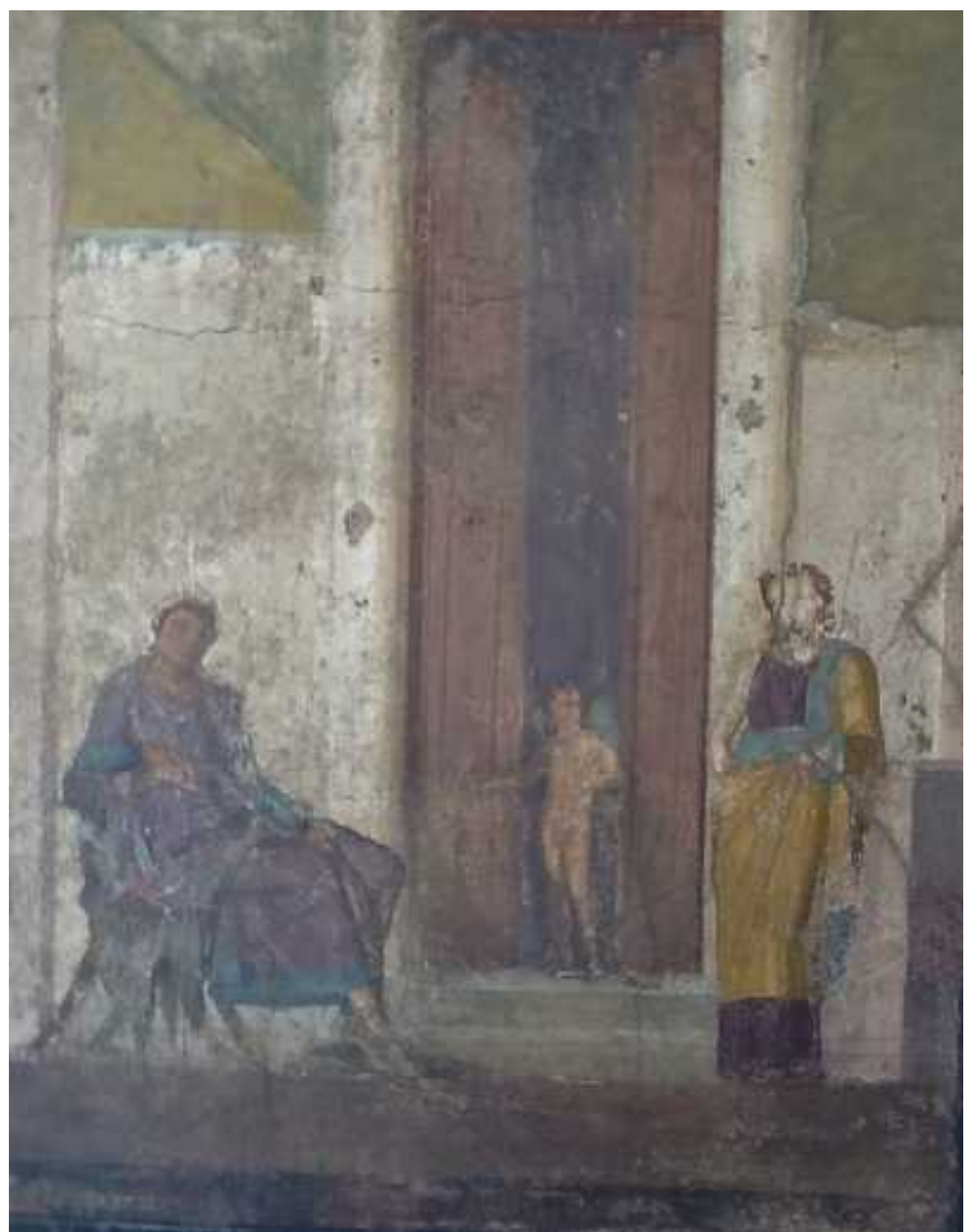

Figura 47. Cupido entre Páris e Helena ${ }^{72}$

\footnotetext{
${ }^{721}$ Sampaolo (2009:238).

${ }^{722}$ Museo Archeologico Nazionale di Napoli, Nápoles, Itália. Inv.: 114320. Pompeia. Casa de Jasão. IX 5, 18, cubículo (e). Alt.: $101 \mathrm{~cm}$. Larg.: 130 cm. Datação: 20-25 d.C.
} 
Na segunda parte da elegia $2.34^{723}$, Amor é identificado pelos efeitos que causa em Linceu, especialmente a insânia. O poeta é aconselhado a mudar os temas de suas poesias e buscar outros paradigmas:

\author{
Lynceus ipse meus seros insanit amores! \\ serum te nostros laetor adire deos. \\ quid tua Socraticis tibi nunc sapientia libris \\ proderit aut rerum dicere posse vias? \\ aut quid Cretaei tibi prosunt carmina plectri? \\ nil iuvat in magno vester amore senex. \\ tu satius Musis leviorem imitere Philitan \\ et non inflati somnia Callimachi. ${ }^{724}$ \\ Até meu amigo Linceu está louco com amores tardios! \\ Alegro-me que tu, ainda que tarde, recorras aos nossos deuses! \\ De que te valerá agora tua sabedoria dos livros socráticos, \\ ou poder explicar as leis do universo? \\ De que te servem os cantos da lira cretense? \\ Vosso ancião nada ajuda em um grande amor. \\ É melhor que tu imites a Musa mais leve de Filitas \\ e o sonho não inflado de Calímaco.
}

Fedelli ${ }^{725}$ observa que o verso 25 é considerado por alguns autores como o início de outro poema, pois supõe-se que Linceu possua uma nova paixão. Assim como Propércio e Pôntico ${ }^{726}$, Linceu é mais um poeta a ser ferido pelas setas de Amor, passando a sofrer todo o páthos imputado pelo deus, ao mesmo tempo em que recebe alguns benefícios. A diferença entre Propércio e seus amigos é que ele próprio foi ferido por Amor enquanto jovem e inexperiente ${ }^{727}$, ao passo que Linceu e Pôntico ${ }^{728}$ são poetas experientes em outro gênero de poesia, e por isso sofrerão ainda mais para aprenderem as lições.

Como diz Fedeli ${ }^{729}$, Linceu não é simplesmente um rival no amor, mas um poeta maduro que cultiva a poesia elevada e a filosofia moral e que trata tudo com pompa e

\footnotetext{
${ }^{723}$ Prop., 2.34.25-58.

${ }^{724}$ Prop., 2.34.25-32.

${ }^{725}$ Fedeli (2005:964-ss).

${ }^{726}$ Para Stahl (1985:177), Linceu é “outro Pôntico, porém com teor mais dramático”. Ambos são poetas severos vitimados pelo Amor tardio (serus Amor: Prop., 1.7.20, 2.34.25), que foram tomados pela insânia (insanus, $1.9 .16=2.34 .25$ ), e cujo modo de produzir poesia modificou-se sob a ação do deus (mollis, $1.7 .19=2.34 .42$ ).

${ }^{727}$ Prop., 1.1.1-4.

${ }^{728}$ Prop., 1.7 e 1.9 .

${ }^{729}$ Fedeli (2005:952).
} 
solenidade $^{730}$. Com a adesão a esse novo modo de vida sob os auspícios de Amor, o poeta severo empresta sua auctoritas à poesia erótica de Propércio. Como rei entre os jovens no simpósio ${ }^{731}$, Propércio ensina a Linceu as lições que aprendeu com Amor sobre como escrever poesia, e aconselha o amigo a adequar sua poesia, insistindo para que ele abandone os temas sérios e elevados de Ésquilo, Antímaco e Homero, e que comece a imitar os versos suaves e breves de Calímaco e Filetas.

Propércio encerra a segunda parte do poema evidenciando a si próprio como um modelo, construindo sua persona que lembra Horácio nas Odes, como um poeta de origem humilde, sem fortuna e sem triunfos passados, que é elevado à glória e à fama por seus engenhosos versos ${ }^{732}$.

Ele é coroado com a guirlanda no simpósio, regado a vinho e rodeado de mulheres:

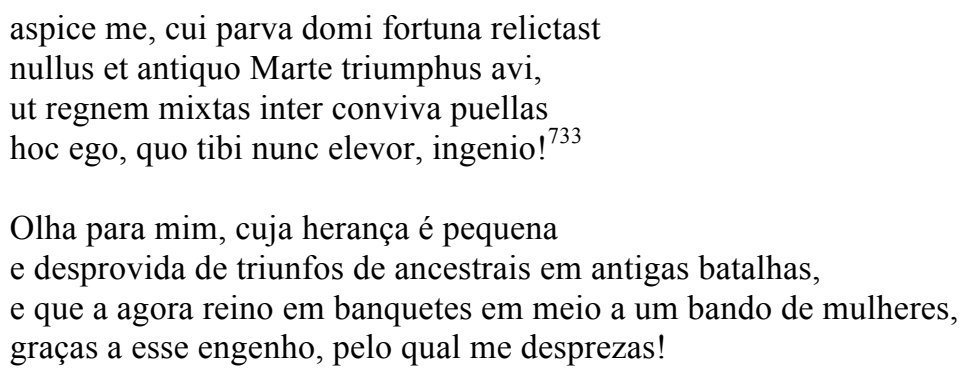

No início da terceira seção da elegia $2.34^{734}$, Cupido é identificado como deus arqueiro de mira inequívoca que atinge Propércio com suas setas no simpósio ${ }^{735}$ :

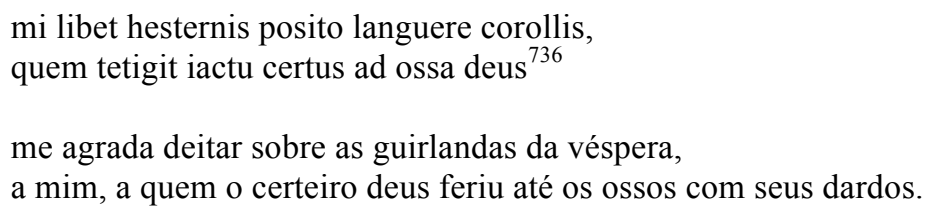

Já discutimos anteriormente presença de Amor no simpósio, e é nesse ambiente que Propércio proclama ter atingido a glória como poeta. $\mathrm{Na}$ pintura abaixo ${ }^{737}$, dois

\footnotetext{
${ }^{730}$ Fedelli $(2005,952)$.

731 Prop., 2.34.57.

${ }^{732}$ Fedelli (2005:987): a referência à origem modesta, acompanhada da reivindicação de um presente enobrecedor próxima da conclusão do livro, aproxima Propércio da técnica de Horácio que contrapõe a modéstia da sua condição a um presente de grande notoriedade na conclusão do livro 3 das Odes.

${ }^{733}$ Prop., 2.34.55-58.

${ }^{734}$ Sobre a divisão deste poema, cf. Stahl (1985:177 e ss.) e Fedelli (2005:951).

${ }^{735}$ Motivo das "guirlandas da véspera", cf. Meleagro, A. P., 5.136.

${ }^{736}$ Prop., 2.34.59-60.

${ }^{737}$ Sobre essa pintura, cf. Sampaolo (2009:103).
} 
Cupidos aparecem em cena simposiástica, um segurando uma bandeja e outro servindo vinho. Ao meio, a guirlanda, motivo ligado ao universo dionisíaco e à poesia:

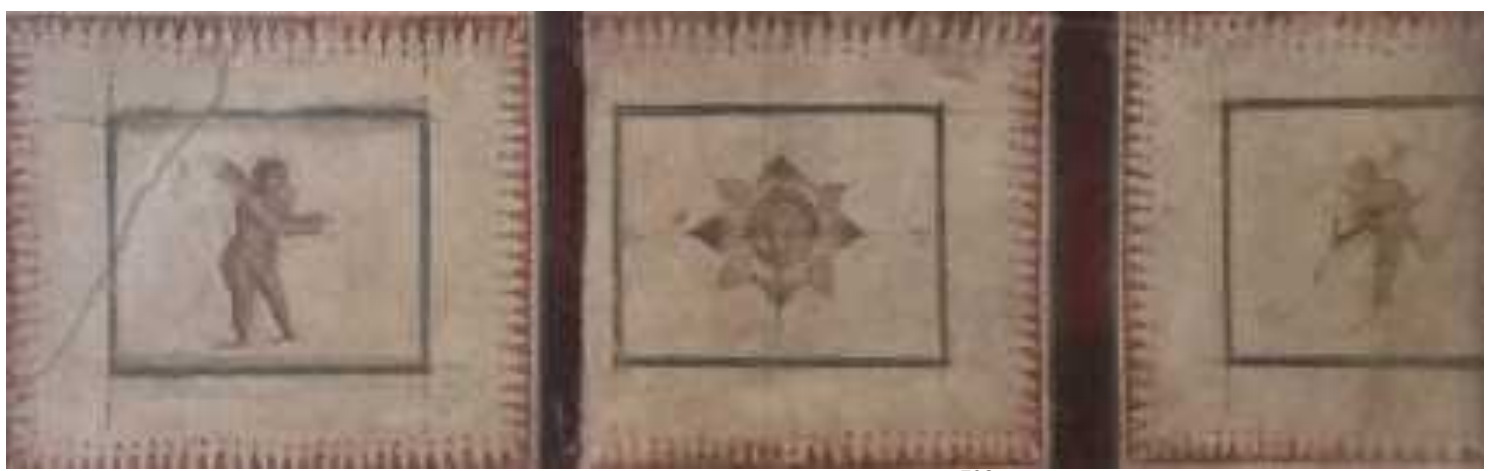

Figura 48. Amorini e guirlanda ${ }^{738}$

Propércio, depois de ser coroado no simpósio, dedica um encômio de 15 versos à obra de Virgílio, que não é modulada por Amor, mas pelo "Cíntio deus"739, um discurso que prepara o caminho para que Propércio sugira que os seus temas superam os de Virgílio. Segundo Fedeli ${ }^{740}$, a apresentação do elogio do Virgílio épico e posterior defesa de sua própria poesia erótica não é ilógica, mas insere-se no esquema das recusationes, em que o poeta de um lado cortesmente confirma seu desinteresse pela poesia épica, e de outro indica alguém que, mais corajoso que ele, é capaz de fazê-lo em seu lugar. O epíteto Cíntio, de Apolo, não ao acaso, ressoa no nome Cíntia, que é a escolhida de Amor para ser a Musa de Propércio, aludindo ao caráter também apolíneo da poesia de Propércio. Sob os auspícios de diferentes deuses, cada poeta é o melhor no gênero que pratica: Propércio, com sua poesia erótica sob os auspícios de Amor, equipara-se a Virgílio com sua épica apolínea, e também alcançará a fama com seus versos. Propércio é mais sutil ao confrontar Amor e Apolo; o certame passa-se mais no plano humano, entre os poetas com suas obras, do que diretamente entre os deuses.

\section{Uma genealogia de poetas de Amor}

Ao longo dos Livros 1 e 2, Propércio aprendeu e ensinou as duras lições de Amor, e por fim foi coroado no ambiente simposiástico com sua poesia erótica de

\footnotetext{
${ }^{738}$ Museo Archeologico Nazionale di Napoli, Nápoles, Itália. Inv. 9168. Riquadri a fondo bianco com Amorini e corolla. Pompei, Casa di Giuseppe II. VII 2, 39, cubicolo. Alt. cm. 28; largh. cm. 85; 30-20 a.C.

${ }^{739}$ Prop., 2.34.61-76.

${ }^{740}$ Fedelli (2005:988).
} 
scriptorumque meas turba secuta rotas.

quid frustra immissis mecum certatis habenis?

non datur ad Musas currere lata via. ${ }^{747}$

Dizei-me, em que gruta igualmente atenuastes o canto?

E com que pé entrastes? E de que água bebestes?

Ah, longe daqui quem quer que detenha Febo em armas!

Que meu verso prossiga, burilado com suave pedra-pomes,

pelo qual a Fama sublime eleva-me da terra, e

a Musa nascida de mim triunfa com cavalos coroados;

e comigo, no carro, os pequenos Amores são conduzidos

e a turba de escritores segue minhas rodas.

Por que, afrouxadas as rédeas, em vão, disputas comigo?

Não é dado às Musas correr em larga via.

Nos livros 3 e 4, outras divindades da poesia como Apolo, Calíope e Baco substituem Amor; e simultaneamente a temática erótica, central nos livros anteriores, passa a dividir espaço com temas didáticos, épicos, etiológicos, cômicos e iâmbicos.

Ovídio também traça uma genealogia de poetas elegíacos, uma delas incluindo Propércio, Tibulo e Cornélio Galo, que escreveu uma coleção de quatro livros intitulada Amores. Ele diz: Successor fuit hic tibi, Galle, Propertius illi; quartus ab his serie temporis ipse fui. ${ }^{748}$ (Este [Tibulo] foi teu sucessor, Galo, e Propércio o dele. Eu mesmo fui o quarto na série do tempo ${ }^{749}$ ). Em Amores 1.15, Amor aparece como deus tutelar da poesia de Tibulo:

Tityrus et segetes Aeneiaque arma legentur,

Roma triumphati dum caput orbis erit.

Donec erunt ignes arcusque Cupidinis arma,

Discentur numeri, culte Tibulle, tui;

Gallus et Hesperiis et Gallus notus Eois,

Et sua cum Gallo nota Lycoris erit. ${ }^{750}$

Títiro e as searas, e as armas de Eneias serão lidos

enquanto Roma for a capital do orbe sobre o qual triunfa.

Enquanto a chama e o arco forem as armas de Cupido,

Aprender-se-ão teus versos, culto Tibulo,

e Galo, Galo será conhecido pelos filhos de Hespéria e pelos filhos de Éos,

E com Galo conhecida será sua Licóris.

Ironicamente, um deus que possui como um de seus principais atributos o riso, tornou-se divindade tutelar de um gênero que tem o lamento expresso no nome. A esse ponto, já não mais nos impressionamos com tal ironia, pois já nos acostumamos com as ambiguidades, paradoxos, enfim, com as contradições que caracterizam este gênero e a

\footnotetext{
${ }^{747}$ Prop., 3.1.5-14.

${ }^{748}$ Ovídio Tr. 4.10.53-4.

${ }^{749}$ Tradução de F. P. Cairolli.

${ }^{750}$ Ov., Am. 1.15.25-30.
} 
persona de Cupido. Na verdade, é ele raramente figurado em atitude lamentosa; como vimos, ele é cruel e, sob comando de Vênus, causa o sofrimento alheio, divertindo-se com o páthos que desperta com suas setas venenosas. Porém, tanto na poesia como em outras artes, há alguns raros exemplos da expressão de lamento: vimos que ele aparece na pintura do abandono de Ariadne enxugando as lágrimas em solidariedade à heroína. $\mathrm{Na}$ poesia, uma rara passagem encontra-se em Epístulas Ex Ponto ${ }^{751}$, em que Amor aparece cabisbaixo, com os cabelos despenteados, com as asas sujas de lama e sem adornos, como um ícone da condição da poesia erótica de Ovídio naquele momento no exílio. Um outro exemplo se encontra em Amores 3.9, em que Ovídio detalha os diversos aspectos da imagem do deus em atitude lamentosa, por ocasião de um evento específico que é capaz de comover o cruel menino: a morte de Tibulo, um dos principais poetas elegíacos em Roma. Em uma rara pausa de seu sarcasmo e tirania implacáveis, o riso dá lugar às lágrimas:

\footnotetext{
Memnona si mater, mater ploravit Achillem, et tangunt magnas tristia fata deas, flebilis indignos, Elegia, solve capillos! a, nimis ex vero nunc tibi nomen erit! ille tui vates operis, tua fama, Tibullus ardet in extructo, corpus inane, rogo. ecce, puer Veneris fert eversamque pharetram et fractos arcus et sine luce facem; adspice, demissis ut eat miserabilis alis pectoraque infesta tundat aperta manu! excipiunt lacrimas sparsi per colla capilli, oraque singultu concutiente sonant. fratris in Aeneae sic illum funere dicunt egressum tectis, pulcher Iule, tuis; nec minus est confusa Venus moriente Tibullo, quam iuveni rupit cum ferus inguen aper. ${ }^{752}$
}

Se mãe lamentou Mêmnon, se a mãe lamentou Aquiles e ainda tristes fados atingem essas grandes deusas, solta cabelos despenteados, ó lastimosa Elegia. $\mathrm{Ah}$ !, agora tu terás muito mais um nome de verdade. Aquele poeta dedicado ao teu gênero, Tibulo, tua glória, arde, corpo inane, na pira erguida. Eis: o menino de Vênus traz caída aljava, o arco quebrado e seu facho já apagado. Vê como, baixadas as asas, caminha deplorável e como bate a mão cruel no peito nu. Os cabelos pelo colo esparsos recolhem lágrimas e a boca ressoa de soluços entrecortados.

Dizem, ó belo Iulo, que assim ele saiu de tua casa para os funerais de Enéias, seu irmão, e Vênus não se afligiu menos ao morrer Tibulo do que quando o fero javali lacerou o flanco do jovem. ${ }^{753}$

\footnotetext{
${ }^{751}$ Ov., Pont. 3.3.13-22.

752 Ov., Am. 3.9.1.16
} 
A partícula demonstrativa ecce no início do verso 7 chama atenção para o aspecto visual da passagem. Identifica-se a vividez do discurso na pormenorização de cada detalhe da imago de Cupido: suas armas, a face, cabelos, as asas e a atitude corporal. O uso de verbos no Presente sugere a ideia de simultaneidade do testemunho visual, elementos que contribuem para a produção de fantasia, que como sabemos, fustiga os afetos.

Com a morte do poeta elegíaco, as armas de Cupido não têm mais serventia; suas setas se quebram e a tocha se apaga. Os versos, ecce, puer Veneris fert eversamque faretram et fractos arcus et sine luce facem, lembram a passagem abaixo de Tibulo, que, incapaz de recusar as guerras de Vênus, deseja ver as armas do deus destruídas para pôr fim à sua angústia:

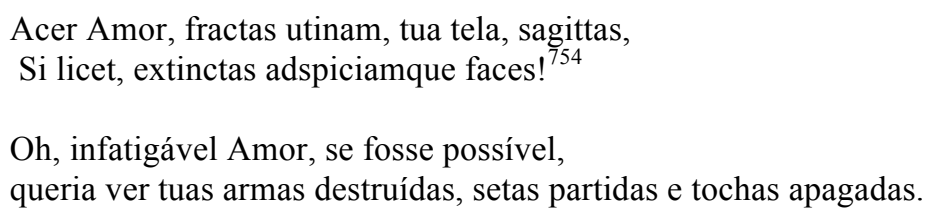

Segundo Reed ${ }^{755}$, Ovídio em Amores 3.9 combina os versos de Tibulo com outra referência, o Epitáfio a Adonis ${ }^{756}$, de Bion de Smirna, em que os Amores choram e descabelam-se ao redor do falecido Adonis; cada qual trazendo um armamento diferente como oferenda, como arco e flecha, para depositar no caixão. Os Erotes apagam a tocha nupcial de Afrodite e mudam da canção matrimonial para o lamento. O lamento dos sempre tão risonhos deuses do amor pela morte de Tibulo reforça a centralidade da matéria erótica na elegia romana, evidenciando Vênus e especialmente Cupido como deuses tutelares da poesia.

\section{Amor na memória e no esquecimento}

Vimos que Propércio, depois de ter ensinado e aprendido as artes do amor, finaliza o programa poético dos Livros 1 e 2, encerrando a participação de Cupido como deus tutelar de sua poesia, e descomprometendo-se com a prioridade da matéria erótica

\footnotetext{
753 Tradução de J. A. Oliva Neto.

${ }^{754}$ Tib., 2.6.15-16.

${ }^{755}$ Reed (1997:261).

${ }^{756}$ Bion, Epitáfio a Adonis, 80-83.
} 
nos livros seguintes. Ovídio, por sua vez, após os Amores, alegando manter a fidelidade a Amor, escreve Ars Amatoria e Remedia Amoris, ensinando, respectivamente, como proceder no amor e como curar-se da ferida causada pelo deus.

Para Volk ${ }^{757}$, o triunfo de Ovídio sobre Amor completa-se nos Remedia Amoris, obra em que o poeta oferece ajuda a todo aquele que, mesmo depois de ter aprendido os preceitos da Ars, ainda precise de ajuda para livrar-se do amor, contrariando a ideia de que este é um mal incurável. Para essa autora, é como se, ao longo de Amores, Ars e Remedia, o poeta conseguisse "matar" o gênero elegíaco. Em Amores, Cupido triunfa rapidamente sobre o poeta, que logo começa a praticar o gênero imposto pelo deus. Na Ars, Ovídio inverte os papéis e assume a persona do praeceptor, tal como Quirão foi do selvagem Aquiles, e ousadamente propõe-se a ensinar aos leitores maneiras de atrair e conquistar Amor, revisitando as tópicas eróticas de Amores em tom didático:

Siquis in hoc artem populo non novit amandi, Hoc legat et lecto carmine doctus amet.

Arte citae veloque rates remoque moventur, Arte leves currus: arte regendus amor.

Curribus Automedon lentisque erat aptus habenis, Tiphys in Haemonia puppe magister erat:

Me Venus artificem tenero praefecit Amori; Tiphys et Automedon dicar Amoris ego. Ille quidem ferus est et qui mihi saepe repugnet: Sed puer est, aetas mollis et apta regi. Phillyrides puerum cithara perfecit Achillem, Atque animos placida contudit arte feros. Qui totiens socios, totiens exterruit hostes, Creditur annosum pertimuisse senem. Quas Hector sensurus erat, poscente magistro Verberibus iussas praebuit ille manus.

Aeacidae Chiron, ego sum praeceptor Amoris:

Saevus uterque puer, natus uterque dea.

Sed tamen et tauri cervix oneratur aratro,

Frenaque magnanimi dente teruntur equi;

Et mihi cedet Amor, quamvis mea vulneret arcu

Pectora, iactatas excutiatque faces.

Quo me fixit Amor, quo me violentius ussit, Hoc melior facti vulneris ultor ero:

Non ego, Phoebe, datas a te mihi mentiar artes, Nec nos aëriae voce monemur avis, Nec mihi sunt visae Clio Cliusque sorores Servanti pecudes vallibus, Ascra, tuis: Usus opus movet hoc: vati parete perito; Vera canam: coeptis, mater Amoris, ades! $!^{758}$

Se houver alguém nesse povo que desconheça a arte de amar, leia isto, e tendo lido o meu poema, ame doutamente. Pela arte movem-se velozes naus com velas e remos

\footnotetext{
${ }^{757}$ Volk (2010:47).

${ }^{758}$ Ov., Ars 1.1-30.
} 
e, pela arte, os leves carros: Amor também deve ser regido pela arte.

Automedonte era hábil com carros e ligeiras rédeas,

Tífis era o comandante do navio Hemônio:

A mim, Vênus enviou como mestre do tênue Amor.

Eu serei chamado de Tífis e Automedonte de Amor;

ele, que é selvagem e que sempre me enfrenta.

Mas ele é menino, idade tenra e própria para receber ordens.

Filírides ensinou o menino Aquiles a tocar a lira com perfeição,

e o seu ânimo feroz foi controlado pela plácida arte.

Dizem que aquele que tantas vezes aterrorizou os companheiros,

e tantas outras o inimigo, intimidou-se diante um velho idoso.

As mãos que Heitor haveria de sentir,

ele estendia obedientemente ao látego, sob as ordens do mestre.

Eu sou preceptor de Amor, assim como Quirão do Eácida.

Ambos cruéis meninos, cada qual nascido de uma deusa.

No entanto, sob a cerviz do touro pesa o arado,

e imponente garanhão range os dentes nas rédeas;

e Amor se renderá a mim, embora tenha me ferido no peito

com seu arco e lançado sobre mim sua agitada tocha.

Quanto mais Amor tiver me transpassado, quanto mais violentamente me abrasado, melhor vingador serei do causador das feridas:

Febo, eu não irei mentir que tu confiastes tuas artes a mim,

nem sou orientado pela voz de uma ave do céu,

tampouco vi Clio e as irmãs de Clio

enquanto pastava o gado nos teus vales, ó Ascra.

A experiência move esta obra: ouve o que diz o perito vate;

cantarei coisas verdadeiras: sê propícia ao meu intento, mãe dos Amores!

Virgílio, no final da écloga $10^{759}$, nas palavras de Galo, reconhece a onipotência do cruel Amor: omnia uincit Amor: et nos cedamus Amori.' (Amor a tudo supera: e nós, cedamos a Amor!). Ovídio, por sua vez, no início da $\operatorname{Ars}^{760}$, ousadamente propõe uma disputa com Amor pela soberania sobre os seus impérios (et mihi cedet Amor) ${ }^{761}$. Nos Remedia, a disputa não é diretamente entre o poeta e o deus, como se propõe na Ars, mas entre amar e não amar. Depois de um acordo, Amor permite que Ovídio assuma o papel de praeceptor para ensinar os remédios do amor a uma audiência de jovens. Ovídio declara-se um vate de Cupido, e apesar da suspeita do deus, alega não estar em guerra com ele, nem ser um traidor, mas reafirma seu constante empenho em manter-se sob os seus auspícios, escrevendo versos elegíacos, a assim perpetuando, por meio da renúncia, o seu implacável poder. No entanto, o poeta propõe ajustes na esfera de atividade do deus, que deve ser assíduo nas guerras de Vênus, e não nas de seu sanguinário padrasto Marte. Desse modo, as paixões felizes permaneceriam, sendo o poeta, assim, beneficiado, pois segundo afirma, é um amante inveterado:

\footnotetext{
${ }^{759}$ Virg., Ecl. 10.69.

760 Ov., Ars 1.12 .

${ }^{761}$ Hardie (2006:176-178). "Lethaeus Amor". In: Gibson, Green, Sharrock (ed.) The Art of Love. Bimillenial essays on Ovid's Ars Amatoria and Remedia Amoris, pp. 170-190. New York: Oxford University Press.
} 
Legerat huius Amor titulum nomenque libelli:

'Bella mihi, video, bella parantur' ait.

'Parce tuum vatem sceleris damnare, Cupido,

Tradita qui toties te duce signa tuli.

Non ego Tydides, a quo tua saucia mater

In liquidum rediit aethera Martis equis.

Saepe tepent alii iuvenes: ego semper amavi,

Et si, quid faciam, nunc quoque, quaeris, amo.

Quin etiam docui, qua posses arte parari,

Et quod nunc ratio est, impetus ante fuit.

$\mathrm{Nec}$ te, blande puer, nec nostras prodimus artes,

$\mathrm{Nec}$ nova praeteritum Musa retexit opus.

Siquis amat quod amare iuvat, feliciter ardens

Gaudeat, et vento naviget ille suo.

At siquis male fert indignae regna puellae,

Ne pereat, nostrae sentiat artis opem. ${ }^{762}$

Amor leu o título e o nome deste livro:

"Vejo que preparam-se guerras, guerras contra mim", disse.

Para de condenar o teu vate por crimes, Cupido!

$\mathrm{Eu}$, que tanta vez carreguei a insígnia a mim concedida sob o teu comando!

Eu não sou o filho de Tideu, de quem tua mãe, ferida, fugiu

no carro de Marte de volta para o límpido céu.

Não raro, outros jovens ardem: eu estou sempre amando,

e se quiseres saber agora também o que faço, eu amo.

Mas, no entanto, ensinei por qual arte tu podes ser conquistado.

E o que agora é uma doutrina, antes era um impulso.

Não traímos nem a ti, nem às nossas artes, afável menino,

nem a nova Musa desfez obra do passado.

Se alguém ama porque amar dá prazer, que ele goze

com sua venturosa paixão e navegue a favor do vento.

Mas se alguém estiver padecendo da tirania de uma mulher indigna,

se não perecer, que experimente os recursos de nossa arte.

Como observa Hardie ${ }^{763}$, o poeta insiste em uma separação que consiste em dizer sim ao amor como técnica de sedução, e não ao amor como afeto destrutivo. Ele propõe ao deus um acordo para que a cura limite-se àqueles tocados pela peste mortal, de amores fatídicos como o de Medeia ou de Dido e de outros relacionamentos trágicos e épicos; por outro lado, permaneceria incurável o amor sem consequências fatais, como a paixão elegíaca do poeta em Amores.

Remedia Amoris é uma obra didática paradoxal, uma vez que não tem por objetivo construir uma doutrina: o poeta já é douto no amor, tendo dominado o impulso e a crueldade do deus com a Ars. Com os Remedia, em vez disso, ele propõe desconstruir e evacuar: dum bene de uacuo pectore cedat amor ${ }^{764}$ (até que Amor se retire do peito vazio). Chama atenção o verbo retexo no verso 12, na passagem em que o

\footnotetext{
762 Ov., Rem.1-15.

${ }^{763}$ Hardie (2006:168-173).

${ }^{764}$ Ov., Rem. 752.
} 
poeta diz não estar desfazendo obra anterior, mas argumenta estar ensinando apenas modos de deter e afastar o amor tirano de consequências fatais.

Depois da argumentação do poeta sobre sua motivação para escrever a obra proposta, Cupido autoriza a sua realização e bate as asas; um gesto que, além ter o sentido de assentir ao pedido, indica que o deus esta prestes a voar e ir embora, excluindo-se como audiência dos preceitos que o poeta está prestes a transmitir. Ovídio dirige-se aos jovens enganados no amor, já doutos, leitores de suas obras anteriores, Amores e Ars Amatoria:

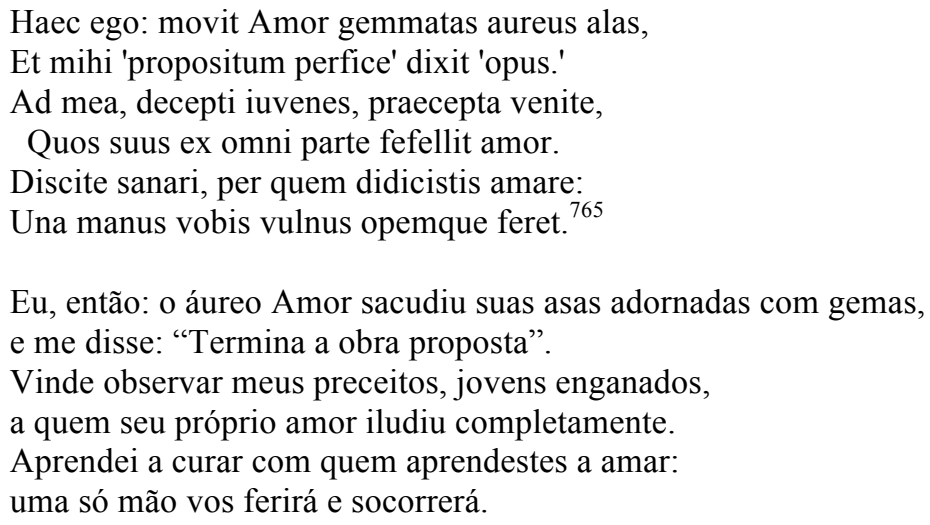

Nos Remedia Amoris, depois da partida de Cupido, Ovídio invoca Apolo como deus da cura e da poesia ${ }^{766}$, que aparece também em resposta a uma segunda invocação ao final do poema ${ }^{767}$. Porém a divindade tutelar da obra é Lethaeus Amor, que, em uma epifania, ensina ao poeta os preceitos da cura do amor, uma incumbência paradoxal para aquele que é mais conhecido como o causador da doença. Evidencia-se, assim, mais uma dualidade no caráter do deus, com seu duplo poder de desencadear e de sanar as feridas do amor, assim como Apolo é o deus da cura e da peste.

Nos Remedia Amoris, Ovídio menciona a presença de Lethaeus Amor no templo de Vênus Ericina, em uma cena epifânica em que o poeta diz ter ouvido palavras proferidas pelo deus. Como havíamos mencionado anteriormente, em Roma, dois templos haviam sido dedicados a Vênus Ericina; um no Capitólio, Aeneadum Genetrix, e outro próximo à Porta Colina, fora dos muros da cidade. Este último, dedicado em 181 a.C. por Lucio Pórcio Licino, ficou reservado à prática de alguns aspectos do culto da Vênus Ericina da Sicília que não podiam ser celebrados no templo do Capitólio,

\footnotetext{
765 Ov., Rem. 39-44.

${ }^{766}$ Ov., Rem. 75-78.

${ }^{767}$ Ov., Rem. 704-706.
} 
especialmente a prostituição. Ovídio, nos Fastos $^{768}$, refere-se ao templo fora do pomerium como local frequentado por mulheres de rua (puellae uulgares) para celebrar o nume de Vênus, que atendia os votos para melhorar a aparência, o poder de sedução e lucros com a prostituição; além de cuidar de questões de fertilidade, reprodução e assuntos amorosos pessoais. Cultuava-se assim, nesse templo, o aspecto físico da deusa, e sua capacidade de capturar pela sedução e de mover a vida dos seres pelo desejo, tal como Lucrécio apresenta-a no De Rerum Natura ${ }^{769}$. Vitrúvio ${ }^{770}$ explica que o local era estrategicamente localizado fora das portas da cidade para preservar os adolescentes e mães de família afastados das paixões inspiradas por esse aspecto do culto da deusa (veneria libido). Apesar disso, o local ocasionalmente era frequentado por pessoas de todas as classes, que iam participar de festivais como a Venerália, quando queimava-se muito incenso e usava-se adornos na cabeça com plantas aromáticas, como menta, rosas e mirto. Ovídio, nos Fastos ${ }^{771}$, além das prostitutas, exorta também as noivas e mães a tomarem parte nesse louvor a Vênus. Ele descreve um ritual de lavagem e adorno da imagem da deusa. Nos Remedia, no templo de Vênus Ericina, Amor dirige-se ao poeta como um igual, com poderes de causar e sanar as feridas do amor:

\footnotetext{
Est prope Collinam templum venerabile portam; Inposuit templo nomina celsus Eryx:

Est illic Lethaeus Amor, qui pectora sanat, Inque suas gelidam lampadas addit aquam. Illic et iuvenes votis oblivia poscunt, Et siqua est duro capta puella viro. Is mihi sic dixit (dubito, verusne Cupido, An somnus fuerit: sed puto, somnus erat) 'O qui sollicitos modo das, modo demis amores, Adice praeceptis hoc quoque, Naso, tuis.

Ad mala quisque animum referat sua, ponet amorem; Omnibus illa deus plusve minusve dedit. ${ }^{772}$

Há um templo venerável próximo à Porta Colina; o elevado Érix deu-lhe o nome: ali encontra-se Lethaeus ${ }^{773}$ Amor, que sana o peito, e com sua gélida água apaga suas tochas.

Ali os amantes pedem para esquecer dos seus votos, e assim o faz a moça apaixonada por homem rude. Ele assim me disse (não estou certo se era Cupido, ou um sonho: mas creio que era um sonho)

"Oh, tu que ora causas, ora eliminas os agitados amores, Nasão, acrescenta esses preceitos aos teus.
}

\footnotetext{
${ }^{768}$ Ov., Fast. 4.863-876.

${ }^{769}$ Lucr., De Rerum Natura, 1.1.

${ }^{770}$ Vitr., 1.7.1.

${ }^{771}$ Venerália, cf. Ov., Fast. 133-139 e Boyle (2000:234-235).

${ }^{772}$ Ov., Rem. 550-560.

${ }^{773}$ Referente ao Lete, rio do esquecimento.
} 
Se cada qual preocupar-se com os seus males, afastará os amores; isso a divindade deu a todos em maior ou menor quantidade.

Nessa passagem, evidencia-se uma face mais branda do deus, que atende súplicas de ordem pessoal e votos de amor feliz, diferente daquela que se configura em associação com as guerras sanguinárias de Marte. Como havíamos dito, no Simpósio ${ }^{774}$, Platão menciona duas Afrodites, a Urânia, elevada, e a Pandêmia, popular, cada qual com o seu Eros. Os romanos também separaram, ao seu modo, em Roma, a sua Vênus Ericina-Victrix-Genetrix, elevada, patrona das vitórias na guerra e ancestral dos romanos, da Ericina popular, que era adorada fora dos muros da cidade. As funções do Eros da Afrodite Pândemia, ligadas ao amor físico e ao uso do corpo como objeto de prazer, coincidem com as do Cupido da Ericina popular.

Na pintura abaixo evidencia-se a beleza física de Vênus: adornada com joias, ela segura Cupido com uma das mãos, enquanto com a outra sensualmente prende a ponta da veste que cobre apenas parcialmente sua nudez. Ele, por sua vez, tem nas mãos um espelho, atributo de Vênus que remete à forma:

\footnotetext{
${ }^{774}$ Platão, Sym.
} 


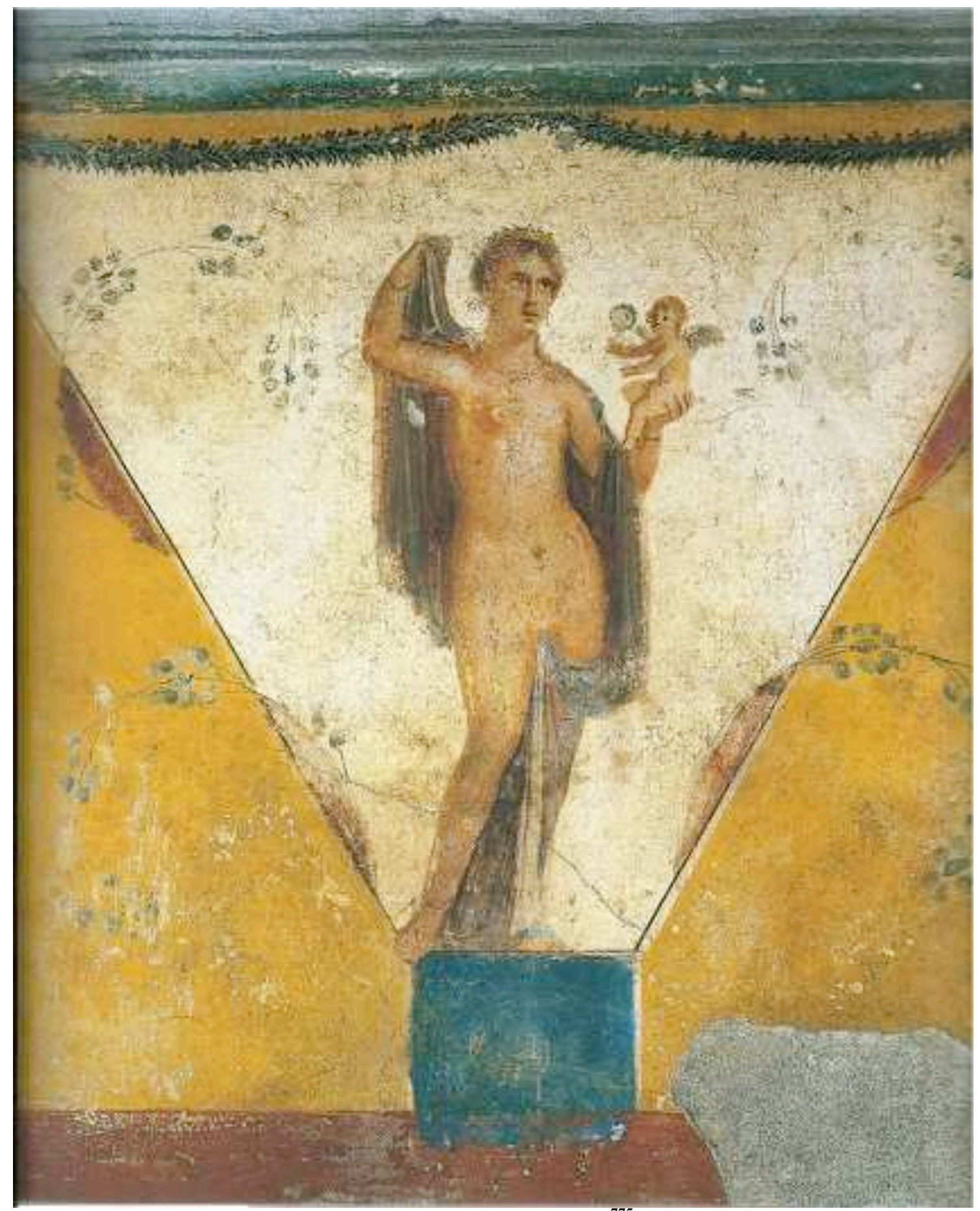

Figura 49. Vênus e Cupido ${ }^{77}$

Nas Geórgicas, o amor é tratado como afeto que tem o poder de causar nos seres o esquecimento de tudo que não seja pertinente a ele próprio:

Omne adeo genus in terris hominumque ferarumque et genus aequoreum, pecudes pictaeque uolucres, in furias ignemque ruunt: amor omnibus idem. tempore non alio catulorum oblita leaena saeuior errauit campis ${ }^{776}$

\footnotetext{
${ }^{775}$ Casa de Júlio Políbio, Pompeia. Afresco.

${ }^{776}$ Verg., G. 3.242-246.
} 


\begin{abstract}
Todas as raças de homens e feras da terra e criaturas marinhas, gado e pássaros multicores, caem nas chamas da paixão: o amor é o mesmo em todos. Em nenhum outro tempo a leoa, esquecida dos filhotes, errou nos campos mais selvagem.
\end{abstract}

Por outro lado, nos Remedia, a figura de Lethaeus Amor promove o esquecimento, anulando o seu próprio poder de seduzir pela forma e capturar a mente.

Nas Éclogas ${ }^{777}$, Virgílio menciona os solliciti amores de Galo por Licóris, um amor agitado, que causa inquietude, perturbação, em outras palavras, que não sai da mente, e que tudo vence. Ovídio, por sua vez, que rapidamente rendeu-se a esse poder em Amores $^{778}$, nos Remedia ${ }^{779}$, tem a habilidade, legitimada pelo deus, de remover essas inquietudes (solliciti amores) que atribulam a mente.

Lethaeus Amor, ao ensinar a arte do esquecimento para afastar o amor, contrapõe-se a Apolo como deus que sugere que se aprenda o autoconhecimento para atrair o amor $^{780}$. Nesse sentido, os poderes de Cupido assemelham-se aos das Musas hesiódicas $^{781}$, fillhas da Memória, paradoxalmente nascidas para "oblívio dos males e pausa das aflições" ${ }^{782}$.

Amor, como deus do esquecimento, pode agir na mente, não apenas apagando o fogo do amor com sua gélida água, mas também desviando a conduta do indivíduo pela distração. Nos Remedia, Ovídio afirma que o otium ${ }^{783}$, tempo livre de preocupações, é a pior condição para aquele que quer afastar Amor, uma vez que este é um dos principais meios de atrair e de manter a presença do deus. Segundo Guerreri ${ }^{784}$, a estátua de Eros, abaixo é chamada de Eros distraído, especialmente devido à suavidade do tratamento da figura, que sugere que o menino alado, prestes a lançar suas flechas, tenha se distraído com algo, uma atitude associada ao seu caráter lúdico e frívolo. Nesse sentido, a distração, nesta pintura, corresponde à atitude que ele próprio empresta aos amantes ao se instalar, desviando a mente e deturpando a razão:

\footnotetext{
${ }^{777}$ Verg., Ecl. 10.6.

${ }^{778}$ Ov., Am. 1.2.11.

${ }^{779}$ Ov., Rem. 557.

780 Ov., Ars 2.493-510.

${ }^{781}$ Hes., Teog. 53-55.

${ }^{782}$ Tradução de J. Torrano.

${ }^{783}$ Ov., Rem. 139-140.

${ }^{784}$ Guerreri (2007:46).
} 


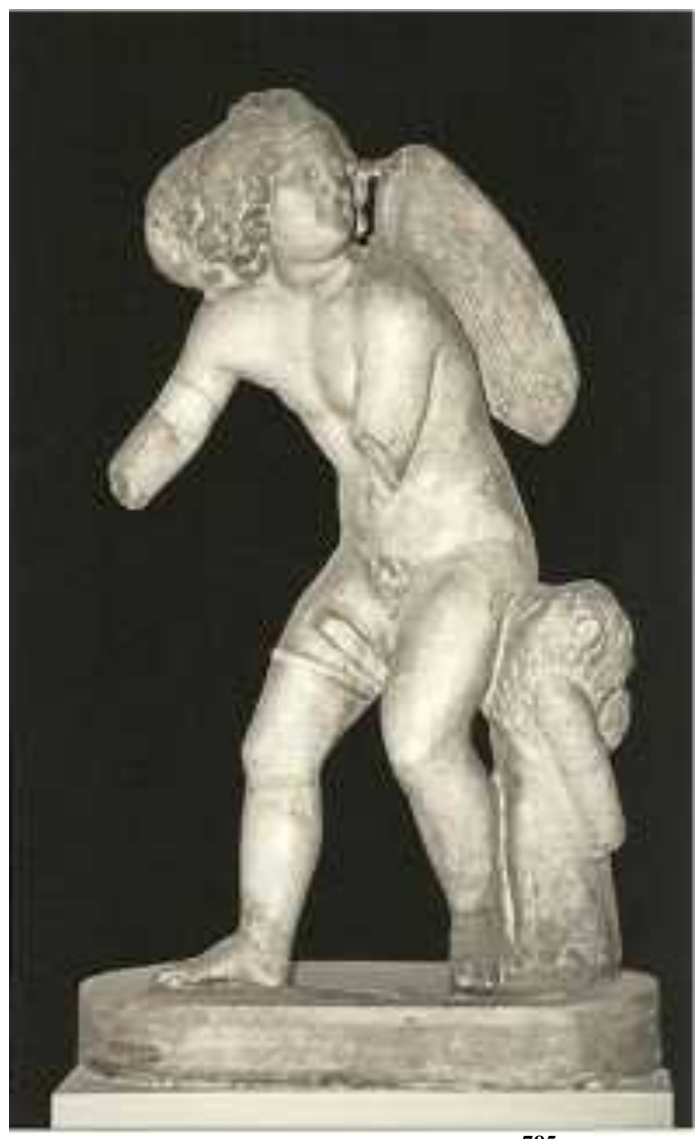

Figura 50. Eros distraído ${ }^{785}$

O exemplo dos elegíacos augustanos contribui para minar a ideia de que é possível escapar ou vencer o poder de Amor. No entanto, nos Remedia, Lethaeus Amor ensina a extinguir o seriutium amoris, sugerindo a substituição das inquietações amorosas por interesses mais prementes. Como observa Hardie ${ }^{786}$, a habilidade de abandonar os amores é inerente aos heróis da épica, cujas relações amorosas muita vez são movidas por um processo de memória e esquecimento. $\mathrm{Na}$ Odisseia, Ulisses consegue abandonar a apaixonada Circe e seguir seu caminho. Na Eneida, Dido, iludida por Vênus e Cupido, esquece-se de $\operatorname{Siqueu}^{787}$ e de suas obrigações como chefe de um povo $^{788}$, e revolve na mente a imagem de Eneias, entregando-se a um insano amor. $\mathrm{O}$ herói, por sua vez, se esquece do amor pela rainha cartaginesa, ficando livre para dar prosseguimento ao seu destino épico.

\footnotetext{
${ }^{785}$ Museo Archeologico Nazionale, Venezia. Gruppo in marmo. Dalla collezione Grimani. Cópia del I secolo d.C. Da um originale di ambito lisippeo.

${ }^{786}$ Hardie (2006:178).

${ }^{787}$ Verg, $A .1 .717-722$.

${ }^{788}$ Virg., A. 4.86-89.
} 
Nos Remedia, Ovídio, dialoga especialmente com a Eneida na construção dos atributos de Lethaeus Amor, mas tem seu próprio expediente ao tratar o tema da memória e do esquecimento:

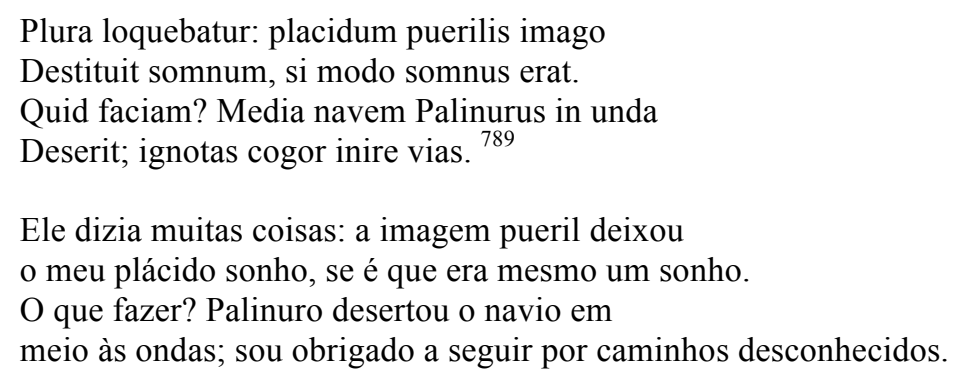

Hardie observa, nos Remedia, semelhanças de Lethaeus Amor com Mercúrio na Eneida, especialmente o fato de sumir do campo de visão do poeta em meio ao seu discurso. Mercúrio na Eneida, em aparições e sonhos, alertava Eneias sobre os seus deveres heroicos e sumia repentinamente ${ }^{790}$

A passagem acima dialoga também com a elegia 2.12 de Propércio, que declara não conseguir ver-se livre do deus, pois ele não voa de seu peito para lugar algum. Ovídio, por sua vez, diz que a puerilis imago de Amor desapareceu diante de seus olhos como num sonho. O desaparecimento do deus o libera do seruitium amoris, e é a contrapartida da arte de fazê-lo permanecer, proposta na $\operatorname{Ars}^{791}$ : Magna paro, quas possit Amor remanere per artes, dicere (Preparo elevada obra que versa por quais artes se pode manter a presença de Amor). Lethaeus associa-se ao sonho, ao sono e ao Lete, o rio do esquecimento, e a última travessura do menino é sumir antes que se note, com a mesma rapidez com que costuma atacar, desvanecendo-se da imaginação do poeta. Com os Amores, Ars e Remedia, Ovídio move-se sob os auspícios de Cupido, aprendendo e ensinando a vivenciar, nutrir e aniquilar o amor, lidando constantemente com a dupla face do deus, que assim como sua dupla seta, tem a capacidade de atrair e de repelir o afeto que provoca.

Com o epílogo dos Remedia, Ovídio lembra o leitor que, tal como Eneias perdeu seu comandante em meio às ondas, ele perdeu a companhia de Cupido, e terá que seguir sozinho por caminhos desconhecidos. A partir desse ponto, a participação de Cupido como deus tutelar da obra de Ovídio se encerra, porém ele não desaparece por completo. Ovídio continua a trazê-lo de volta em epifanias. Nos Tristia, ele evidencia a imagem de

\footnotetext{
${ }^{789}$ Ov, Rem. 575-578.

${ }^{790}$ Verg., A. 4.267.

${ }^{791}$ Ov., Ars 2.17.
} 
Amor em estado degradante, como um retrato de sua poesia erótica naquele momento de angústia e lamento. Diferente daquela figura arrogante dos Amores $^{792}$, ou do indignado deus dos Remedia ${ }^{793}$, nos Tristia, ele aparece desanimado, com os cabelos desgrenhados, asas sujas, e tudo o que havia de mais exuberante e brilhante em sua aparência torna-se opaco e decadente:

\footnotetext{
Stabat Amor, uultu non quo prius esse solebat, fulcra tenens laeua tristis acerna manu, nec torquem collo neque habens crinale capillo nec bene dispositas comptus ut ante comas. Horrida pendebant molles super ora capilli et uisa est oculis horrida penna meis, qualis in aeriae tergo solet esse columbae tractatam multae quam tetigere manus.

Hunc simul agnoui - neque enim mihi notior alter talibus adfata est libera lingua sonis: 'O puer, exilii decepto causa magistro, quem fuit utilius non docuisse mihi, huc quoque uenisti, pax est ubi tempore nullo et coit adstrictis barbarus Hister aquis? Quae tibi causa uiae, nisi uti mala nostra uideres, quae sunt, si nescis, inuidiosa tibi? ${ }^{794}$
}

Ali estava Amor, com uma face que não era como antes, e tristemente ele portava na mão esquerda o bastão de ácer, sem colares no pescoço e sem ornamentos nos cabelos, sem as comas penteadas e arrumandas como antes.

Os macios cabelos pendiam sobre a face desleixada, suas asas, aos meus olhos, pareciam eriçadas, como as de uma pomba em voo, que muitas mãos tocaram e alisaram.

Assim que o reconheci, pois não há ninguém que eu conheça melhor, minha língua liberou-se e assim falou:

"Menino, causa maior do meu exílio, a quem seria melhor eu não ter ensinado, tu vens até aqui, onde não há paz em tempo algum, e onde as águas do bárbaro Histrio se congelam?

Que causa o trouxe até aqui, a não ser para contemplar os meus males? Se tu não sabes, estes são os motivos de indignação contra ti.

Contrariando a ideia da Ars de que tenha domado Amor, o poeta agora atribui a culpa ao deus pela realização da obra que ele alega ter sido causa de sua ruína, trocando me duce (sob o meu comando) ${ }^{795}$ que ele havia proclamado na Ars, pelo te duce (sob o teu comando $)^{796}$. O deus replica dizendo que foi o único a ser arruinado pelo próprio

\footnotetext{
792 Ov., Am. 1.1.

793 Ov., Rem. 1-3.

${ }^{794}$ Ov., Pont. 3.3.13-28.

795 Ov., Ars 2.57-58.

796 Ov., Rem. 30.
} 
discípulo $^{797}$. Ovídio dialoga com Cupido, depositando em sua figura a expectativa de que a ira implacável de Augusto possa amolecer e, assim, livrá-lo do exílio:

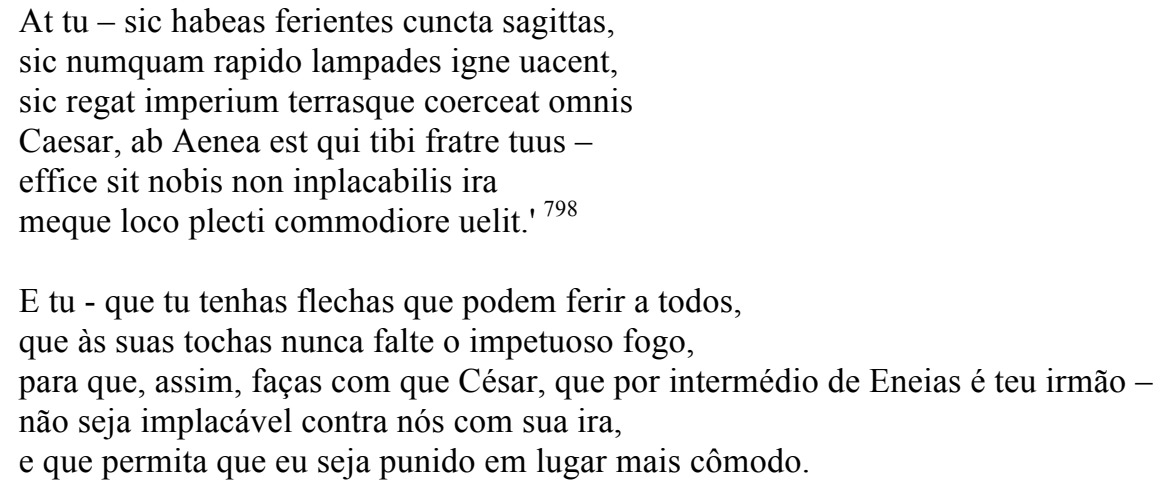

Cupido, antes de partir, sugere que ainda está a seu favor:

Quae nunc cur iterum post saecula longa reuisam tu facis, o castris miles amice meis.

Pone metus igitur: mitescet Caesaris ira et ueniet uotis mollior aura tuis.

Neue moram timeas, tempus quod quaerimus instat cunctaque laetitiae plena triumphus habet.

sperandum est nostras posse ualere preces.

Dixit et aut ille est tenues dilapsus in auras, coeperunt sensus aut uigilare mei. ${ }^{799}$

A razão da minha visita depois de tanto tempo, és tu, ó amigo soldado de minhas milícias.

Então, abandone o medo: a ira de César se abrandará e brisas mais suaves soprarão sobre teus votos.

Não teme a demora, o tempo que esperamos se aproxima: o triunfo encherá tudo de alegria

Esperamos que nossas preces possam valer,

disse, e enquanto ele deslizava pelos leves ares,

os meus sentidos começaram a retornar ao estado de vigília.

Nos Tristia, em discurso endereçado a sua esposa, Ovídio compõe o que ele pede que seja seu próprio epitáfio. Logo no primeiro verso, ele especifica o desejo de eternizar a importância de Amor para sua obra:

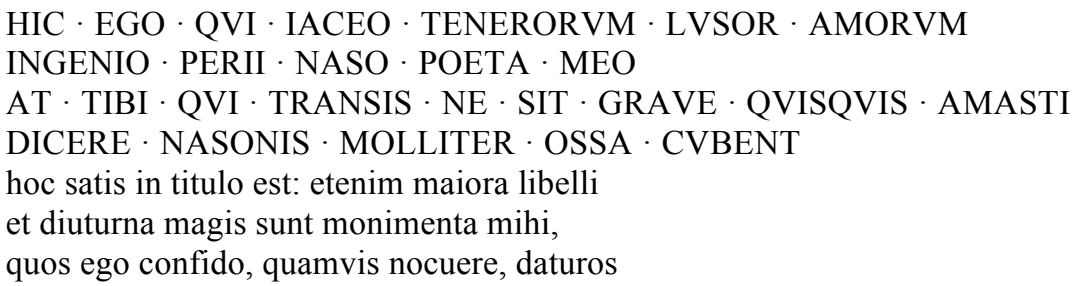

\footnotetext{
797 Ov. Rem. 46.

798 Ov., Ex Ponto, 3.3.60-65.

${ }^{799}$ Ov., Ex Ponto, 3.3.81-86 e 93-95.
} 


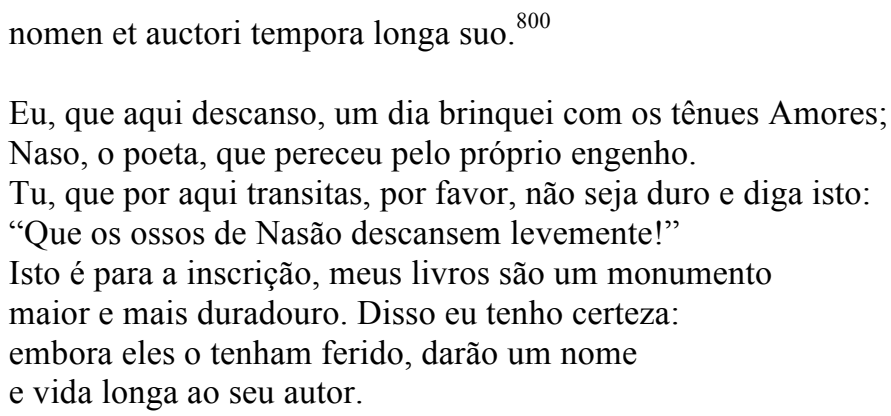

Enfim, talvez, Ovídio, como ele mesmo afirma, conheça Cupido melhor que ninguém; ou, ao menos, talvez ninguém tenha levado suas asas tão longe. Mesmo depois dos Remedia, no exílio, ele continua a revisitar a figura do deus em sua obra, em epifanias que trazem de volta memórias de sua poesia erótica.

${ }^{800}$ Ov., Tr. 3.3.73-80. 


\section{Considerações finais}

Com o percurso em torno das imagines Amoris, por meio da observação de loci, temas e motivos associados a Amor, dando ênfase à poesia latina, e buscando motivos análogos em objetos de arte pertencentes ao final da República e ao Período Augustano em Roma, procuramos uma aproximação com o imaginário desse período, de modo a interpretar com mais precisão os diversos significados das metáforas produzidas pela presença do deus nos textos que nos propusemos a estudar.

O estudo da semântica dos nomes do deus ajudou na reflexão sobre diversos aspectos. Cícero elenca o amor como argumento retórico do discurso judiciário, definindo-o como uma força, um impulso e uma potência que pode levar alguém a cometer um crime. Tais elementos apresentam-se também em associação à persona do deus, por exemplo, na caracterização estóica de Cupido como uis maior, no De Natura Deorum, e também na poesia, na menção ao crimen Amoris na elegia $2.30 \mathrm{~b}$ de Propércio, e na caracterização de Amor como força e potência de Vênus na Eneida. Nota-se o quanto é tênue a linha que separa o uso próprio, referente à personificação, do substantivo comum das palavras amor, puer e cupido, e concluímos que, especialmente nos poemas, a figura do deus pode confundir-se com os efeitos que ele causa, o que dificulta consideravelmente essa distinção em alguns casos.

Discutimos as paixões intrínsecas aos diversos nomes gregos e latinos, e especificamos a transposição não tão direta dos atributos do Eros grego na construção das imagens de Amor em Roma. Observamos esculturas de Eros e Pothos, e poemas que evidenciam a figura do puer delicatus. Vimos imagens do amor criança e como membro do séquito e filho de Vênus, em esculturas, pinturas e poemas gregos e latinos, procurando discernir o modo como as tópicas foram trabalhadas em Roma. Em sua caracterização como membro do séquito de Vênus, percebemos a relação com a Teogonia, na figuração da Afrodite que sai do mar acompanhada de Eros e Himeros. Observamos esta tópica em pinturas, como a da Casa de Vênus Marinha, em Pompeia, e em textos, como o História Natural de Plínio, o Velho. A imagem pueril do férvido menino que atira suas setas constantemente e diverte-se ao lado de sua doce mãe, aparece em epigramas helenísticos, e prolifera intensamente em Roma, acumulando novas metáforas na poesia e nas artes, como procuramos demonstrar. Em poemas de Horácio, o caráter de Vênus chega a confundir-se com o do filho: ambos são igualmente cruéis e riem do sofrimento que causam. 
Cupido pode figurar com e sem a presença de Vênus. Vimos exemplos em que a sua imagem ganha autonomia, por exemplo, a escultura do Eros Adormecido e pinturas parietais da Casa dos Vettii em Pompeia, com os Amorini praticando ofícios e jogos. O Eros arqueiro é uma das figurações mais comuns, presente em pinturas e esculturas, por exemplo, o arqueiro de tipo associado a Lisipo; e na poesia, entre incontáveis ocorrências, podemos mencionar a elegia 2.12, em que Propércio detalha cada um dos atributos do deus, evidenciando o poder e os efeitos de suas flechadas, a rapidez de suas asas, o seu caráter hostil e ao mesmo tempo sedutor, que sempre se impõe.

Alguns poemas de Tibulo e Ovídio exemplificam como Amor conquista com seu caráter doce-amaro, mostrando primeiro a face suave, para depois revelar-se cruel e tirano. O riso fácil, característica que compartilha com a mãe, reverbera seu caráter lúdico, doce e pueril, porém também cruel, como observamos igualmente em epigramas helenísticos.

Discutimos a questão do número de Cupidos por meio da observação de pinturas, esculturas, moedas e poemas. Poemas de Catulo, Ovídio e Horácio, serviram como base para questionarmos os plurais definidos e indefinidos de passagens da poesia, como a menção aos gemini Amores nos Fastos, ou a presença de Iocus e Cupido nas Odes de Horácio.

Virgílio, na Eneida, inclui Amor na missão épica de Vênus. Sua ação, de apenas por uma noite assumir a figura de Ascânio para atingir Dido, tem enormes consequências no rumo da narrativa épica. Ele participa como um delicium na cena do banquete, conquistando a todos com seu brilho e alegria, e vitima Dido ao abraçá-la e transmitir seu calor, que acaba por consumi-la em chamas.

Estudando a relação entre Amor e a figuração dos delicia, consideramos o possível diálogo da arte com a vida, e da vida com a arte. Em Odes 4.1 de Horácio, detectamos especialmente a presença de pueri delicati do tipo Ganimedes e metáforas de captura, imagens encontradas também em pinturas e epigramas. A turba minuta da elegia 2.29.a de Propércio serviu como exemplo da transposição do motivo de Vênus e Cupido para o plano humano, com a amada no papel de Vênus, os escravos como Cupidos e Propércio como um fugitivo. Nesse poema, observamos a alegorização dos desejos na figura dos Pueri, e também a euidentia, efeito de vividez decorrente da pormenorização de seus atributos físicos e anímicos. Encontramos, em pinturas da Casa dos Vettii e em outros objetos de arte, a figuração dos Amorini praticando os mais diversos ofícios, jogos e celebrações, parodiando atitudes e gestos humanos. 
Amor é uma figura volátil, que desloca-se de um lugar para o outro rapidamente antes que se perceba. Ele geralmente instala-se no interior de suas vítimas, controlando seus passos em direção ao objeto desejado, como em Amores 1.6, em que o poeta, em meio às sombras da noite, é levado até as portas da amada. Seu laço, ou uinculum, serve para colocar os amantes sob seu jugo, mas também pode simbolizar a união matrimonial. O tema do casamento estreitou as relações do deus com o mundo feminino, apresentando-se na poesia, na pintura e em outras artes em Roma. Amor também pode apaixonar-se. Ele aparece em união matrimonial com Psiquê, uma figuração encontrada mais na arte do que na poesia. Com a leitura de algumas odes de Horácio, vimos que Cupido pode ser também uma metáfora para o homem desejado. Nesse sentido, aparência e comportamento são quesitos fundamentais no mecanismo de atração e repulsa que está no cerne da ação do deus.

Marte, Vênus e Cupido formam uma paradoxal família de deuses do amor e da guerra em Roma, unindo opostos irreconciliáveis que, no entanto, adequam-se ao contexto da militia amoris. Entre as diversas genealogias de Cupido, vimos, no De Natura Deorum, que ele pode figurar como fruto do amor adúltero entre Marte e Vênus. Há pinturas e relevos que sugerem a ideia de família e, também, a associação desses deuses como ancestrais da gens Iulia e do povo romano. Nesse contexto, Cupido brinca com as armas de Marte, como pequeno guerreiro simulando a luta ao lado do pai e de sua Genetrix. Os poetas, normalmente especificam que Cupido é filho adotivo de Marte, deixando uma incógnita sobre o progenitor do menino, dúvida que é sugerida igualmente em epigramas helenísticos.

A militia amoris tem por eixo os paradoxos da paz e da guerra: os poetas exaltam as guerras no âmbito de Vênus, tomando parte nesses combates em momentos de paz. Ovídio, em Amores 2.9.a, é um soldado em combate ferido por seu próprio comandante, Cupido; em Amores 1.2, na procissão triunfal, Amor desfila na carruagem principal como um César. Poemas de Tibulo exaltam a militia amoris em momentos de paz, especialmente em um cenário de prosperidade que lembra os relevos da Ara Pacis. Poemas elegíacos constroem a figura de Amor na tópica seruitium amoris como custos da puella, a protegida a quem o poeta deverá servir. Na elegia 2.30.a de Propércio, Cupido posiciona-se sobre a cabeça dos amantes, figuração que constatamos também em pinturas, como o tema de Hércules e Ônfale.

Em boa parte dos poemas, Amor apresenta-se com caráter implacável e imbatível, uma imagem que sintetiza-se na tópica omnia uincit Amor. Ele pode 
emprestar sua coragem ao amante e guiar seus passos, levando-o às portas da amada, como vimos em Amores 1.6. Exemplos dessa força de dominação figuram em mosaicos, gemas e pinturas de Cupidos subjugando leões e heróis.

A relação entre Eros e Dioniso se dá especialmente em cenas simposiásticas que sugerem o estado de êxtase proporcionado pela música, bebida e canto, um cenário favorável ao amor. Cupido pode aparecer também ao lado de Baco em cenas como o resgate de Ariadne, da qual vimos uma pintura e a elegia 1.3 de Propércio, em que observa-se a transposição de atributos por meio de símiles que entrecruzam o mundo mortal com o divino: Propércio como Baco, Cíntia como Ariadne e os escravos como Pueri.

Comparamos a ação de Amor em elegias e epodos, especificando os diferentes efeitos e as variações nos êthe dos afetados pela ação do deus. Amor dita as leis do simpósio de Propércio, e Cíntia, sua única Musa, participa da celebração sem dar ouvidos às criticas dos antigos. No simpósio iâmbico, no epodo 11 de Horácio, a ação do deus lembra o pothos solta-membros de Arquíloco; sob os auspícios dessa força avassaladora, os amantes comportam-se de maneira mais volúvel e indiscriminada. Os elegíacos não conseguem libertar-se do seruitium amoris, motivação para o seu lamento amoroso, enquanto no epodo de Horácio, o remédio eficaz para esse mal é a substituição por outro amor.

Estudamos a presença de Amor como deus tutelar da poesia erótica em diversos poemas de recusa, em que ele pode determinar preceptivas como matéria, métrica e elocução. Em Amores 3.1, que apresenta o embate entre a Tragédia e a Elegia, Amor é um deus lascivo, um atributo de diversos significados, que pode evidenciar o caráter erótico da poesia sob sua tutela, e indicar também a poikilia, que é a mistura de tópicas de diversos gêneros, na obra que ele preside. Em elegias de Propércio, como a 1.7, 1.9 e 2.34, Amor apresenta-se no papel de praeceptor do poeta. Este, por sua vez, tendo aprendido as lições, tenta convencer os amigos a aderirem a um novo modo de fazer poesia, privilegiando a temática erótica.

Por fim, nos Remedia, nos deparamos com mais uma habilidade de Amor, que, no papel de Lethaeus, tem o duplo poder de causar e curar o afeto que produz. Nesse sentido, o jogo entre memória e esquecimento é o principal elemento que contribui para a sua própria extinção. 
Concluímos que, longe de ser uma figura meramente decorativa, Amor revela-se uma presença constante, complexa e profundamente arraigada no imaginário da poesia latina e nas artes em Roma. 


\section{Bibliografia}

\section{Traduções e comentários}

APULEIO (1990) Cupid \& Psyche. Edited by E. J. Kenney. Cambridge: Cambridge University Prees.

(1996) Metamorphoses. Books I-VI. With an English Translation by J. A.

Hanson. Cambridge: Harvard University Press.

(2007) The Golden Ass. Translated with introduction by J. C. Relihan. Indianapolis: Hacket Publishing Company.

ARISTÓTELES (1979) Poética. Tradução de Eudoro de Souza. São Paulo: Abril Cultural. (2002) Retórica. Madrid: Alianza Editorial.

(2005) Poetics. Edited and translated by Stephen Halliwel.; Longinus.

On the Sublime, translation by W. H. Fyfe, revised by Donald Russel.; Demetrius.

On Style. Edited and translated by Doreen C. Innes, based on W. Rhys Roberts. Cambridge: Harvard University Press.

(2005) A Poética Clássica. Trad. Jaime Bruna. São Paulo: Editora

Cultrix.

(1957) On the Soul. Parva Naturalia. On Breath. With an English

Translation by W. S. Hett. Cambridge: Harvard University Press.

CATULO (2005) Translated by Francis Warre Cornish. TIBULO. Translated by J. P.

Postgate. Pervigilium Veneris. Translated by J. W. Mackail. Second Edition

Revised by G. P. Goold. Cambridge and London: Harvard University Press.

CÍCERO (1933) De Natura Deorum. Academica. With an English translation by H.

Hackman. Cambridge: Harvard University Press.

FILÓSTRATO, O VELHO. Imagines. FILÓSTRATO, O JOVEM. Imagines.

CALÍSTRATO, Descriptions. (2000) With an English Translation by Arthur

Fairbanks. Cambridge: Harvard University Press.

The Greek Anthology I. Books 1-6. (1993) Translated by W. R. Paton. Cambridge: Harvard University Press.

The Greek Anthology IV. Books 10-12. (1979) Translated by W. R. Paton. Cambridge:

Harvard University Press. 
HESÍODO (2001) Teogonia. Estudo e Tradução Jaa Torrano. São Paulo: Editora Iluminuras Ltda.

HOMERO (2009) Odisseia. Tradução de Carlos Alberto Nunes. São Paulo: Ediouro. (2009) Ilíada. Tradução de Carlos Alberto Nunes. São Paulo: Ediouro.

HORÁCIO (2004) Odes and Epodes. Ed. and Transl. by Niall Rudd. Cambridge: Harvard University Press.

(1984) Arte Poética. Introdução, Tradução e Comentários de R. M. Rosado Fernandes. Lisboa: Editorial Inquérito Limitada.

(1942) Satires, Epistles, Ars Poetica. With an English Translation by H. Rushton Fairclough. Cambridge: Harvard University Press.

(2009) Tutte le Poesie. Ed. Paolo Fedeli. Trad.: Carlo Carena. Torino: G. Einaudi.

(1998) Odes \& Carmen Saeculare. With and English version in the original metres, introduction and notes by Guy Lee. Trowbridge: Redwood Books.

(1980) The Odes. Edited with introduction, Revised Text and Commentary by Kenneth Quinn. London: Bristol Classical Press.

(2012) Odes Book I. Cambridge Greek and Latin Classics. Edited by Roland Mayer. Cambridge: Cambridge University Press.

(1995) Epodes. Edited by D. Mankin. Cambridge: Cambridge University Press.

OVÍDIO (2006) Volume I: Heroides and Amores. Translated by Grant Showerman and revised by G. P. Goold. Cambridge and London: Harvard University Press. (2004) The Art of Love and other Poems. With an English Translation by J. H. Mozley. Cambridge and London: Harvard University Press. Fasti (2000) Translated and Edited with an introduction, notes and glossary by A. J. Boyle and R. D. Wodard. London: Penguin Books. (1996) Tristia. Ex Ponto. Translated by Al L. Wheeler. Revised by G. P. Goold. Cambridge and London: Harvard University Press.

PLATÃO (2008) The Symposium. Edited by M. C. Howatson, F. C. C. Shefield. Translated by M. C. Howatson. Cambridge: Cambridge University Press. (1991) O Banquete. Fédon. Sofísta. Político. Seleção de Textos de José Américo Motta Pessanha. Tradução e notas de José Cavalcante de Souza, Jorge Paleikat e João Cruz Costa. 5 ed. São Paulo: Nova Cultural. 
PLÍNIO, O VELHO (2003) Natural History. Books 33-35. With an English translation by H. Rackham. Cambridge and London: Harvard University Press.

PROPÉRCIO (2006) Elegies. Edited and Translated by G. P. Goold. Cambridge: Harvard University Press.

(2005) Properzio Elegie Libro II. Introduzione, Testo e Commento P. Fedeli. Cambridge: Francis Cairns Publications.

(2002) Elegias. Tradutores: Aieres A. Nascimento (I); Maria Cristina

Pimentel (II); Paulo F. Alberto (III) e J.A. Segurado e Campos (IV). Texto Latino

e Introdução de Paolo Fedeli. Lisboa e Assis: Centro de Estudos Clássicos, Faculdade de Letras de Lisboa e Accademia Properziana Del Subasio.

(1999) Elegies. Book I. Camps. W. A. (ed.) Cambridge: Cambridge

University Press.

VIRGÍLIO (2004) Eclogues, Georgics, Aeneid 1-6. Translated by H. R. Fairclough.

Revised by G. P. Goold. Cambridge: Harvard University Press.

(1981) Eneida. Tradução de Carlos Alberto Nunes. São Paulo: A Montanha.

(2008) Eneida Brasileira: tradução poética da epopéia de Públio Virgílio

Maro. Organização: Paulo Sérgio de Vasconcellos et al.; Tradução: Manuel Odorico Mendes. Campinas: Editora Unicamp.

VITRÚVIO (2002) On Architecture, Books 1-5 e 6-10. Edited and translated by Frank

Granger. Cambridge, Massachussets, London: Harvard University Press

\section{Autores contemporâneos}

F. ACHCAR (1994) Lírica e lugar comum. Alguns temas de Horácio e sua presença em Português. São Paulo: Edusp.

J. N. ADAMS (2002) The Latin Sexual Vocabulary. London: Duckworth.

A. W. ALLEN (1950) "Sincerity" and the Roman Elegists. In: Classical Philology, Vol. 45, No. 3, pp. 145-160. The University of Chicago Press, Jul..

F. V. AMARAL (2009) A guilanda de sua Guirlanda. Epigramas de Meleagro de Gádara: tradução e estudo. Dissertação de Mestrado apresentada ao Programa de Pós-Graduação em Letras Clássicas do Departamento de Letras Clássicas e Vernáculas da USP. 
R. ANCONA (1994) Time and the erotic in Horace's Odes. Durham: Duke University Press.

W. C. ARCHER (1990) The Paintings in the Alae of the Casa dei Vettii and a Definition of the Fourth Pompeian Style. American Journal of Archaeology, Vol. 94, No. 1, pp. 95-123.

B. ARKINS (1993) “The cruel joke of Venus. Horace as a love poet”. In: RUDD, N. (ed.) Horace 2000. A celebration. Essays for the bimillenium. London: Gerald and Duckworth \& Co. Ltd..

R. ARMSTRONG (2005) Ovid and his love poetry. London: Duckworth.

R. B. BANDINELli (1970) Rome. The Center of Power. Roman Art to 200 A.D. Translated by Peter Green. London: Thames and Hudson.

M. BEARD, J. NORTH, S. PRICE (1996) Religions of Rome. Vols 1 and 2. Cambridge: Cambridge University Press.

M. BEARD. The Life of a Roman Town. London: Profile Books, 2008.

A. BEESON (1995) "Venus and the fan". Mosaic. In: The Journal of the Association for the Study and Preservation of Roman Mosaics. Vol. 22, pp. 4-14.

P. BING; J. S. BRUSS (2007) (ed.). Brill's Companion to Helenistic Epigram. Leiden, Boston: Brill.

A. T. S. BRADSHAW (1970) "Horace, Odes 4. 1". The Classical Quarterly, New Series, Vol. 20, No. 1, pp. 142-153.

B. BREITENBERG (2007) Aphrodite and Eros. The development of Erotic Mythology in Early Greek Poetry and Cult. New York: Routledge.

P. BRUNEAU, P. TORELLI, X. B. ALTET (2006) Sculpture - From Antiquity to the Middle Ages. Part I. The Great Art of Antiquity - From the Eight Century B.C. to the Fifth Century A.D. Koln: Taschen.

F. CAIRNS (1971) Propertius, $2.30 \mathrm{~A}$ and B. The Classical Quarterly, New Series, Vol. 21, No. 1, pp. 204-213.

Generic Composition in Greek and Roman Poetry. Ann Arbor: Michigan Classical Press, 2010.

(1971) "Propertius 2. 29A". The Classical Quarterly, New Series, Vol. 21, No. 2, pp. 455-460.

F. P. CAIROLLI (2010) “O fragmento de Galo”. In: Nuntius Antiquus, No. 5, pp. 1-19.

C. CALAME (1999) The poetics of Eros in Ancient Greece. New Jersey: Princeton University Press. 
A. CAMERON (1995) Callimachus and His Critics. Princeton, New Jersey: Princeton University Press.

C. CAPALDI, S. PAFUMI (2009) Le sculture Farnese. I. Le sculture ideali. Verona: Mondadori Electa.

A. CARSON (2009) Eros the bittersweet. Princeton: Princeton University Press.

A. CAVARZERE et al. (ed.) (2001) Iambic Ideas. Essays on a Poetic Tradition from Archaic Greece to the Late Roman Empire. Lanham: Rowman \& Littlefield Publishers, Inc..

J. R. CLARKE (1991) The Houses of Roman Italy, 100 B.C. - A.D. 250. Ritual, Space and Decoration. Berkley and Los Angeles: University of California Press.

(2003) Art in the Lives of Ordinary Romans - Visual Representation and Non-elite Viewers in Italy - 100 b.C - a.D. 315. London: University of California Press.

W. CLAUSEN (1987) Virgil's Aeneid and the tradition of Hellenistic Poetry. Berkeley and Los Angeles: University of California Press.

G. B. CONTE (1999) Latin Literature, a History. Baltimore and London: The Johns Hopkins University Press.

(1991) Generi e lettori. Lucrezio, l'elegia d'amore, l'enciclopedia di Plinio. Milano: Arnoldo Mondadori Editore.

F. O. COPLEY (1947) Servitium amoris in the Roman Elegists. Transactions and Proceedings of the American Philological Association, Vol. 78, pp. 285-300.

G. DAVIS (ed.) (2010) A Companion to Horace. Malden: Wiley-Blackwell.

H. DETTMER (1983) Horace: A Study in Structure. Hildesheim: Olms.

G. DUMÉZIL (1996) Archaic Roman Religion. Translated by Philip Krapp. Vols. 1-2.

Baltimore: Johns Hopkins.

K. M. D. DUNBABIN (2001) Mosaics of the Greek and Roman World. Cambridge: Cambridge University Press.

S. FASCE (1977) Eros la figura e il culto. Genova: Casa Editrice Tilgher-Genova.

E. FATHAM (2004) Ovid's Metamorphoses. New York: Oxford University Press.

W. FITZGERALD (1989) Horace, Pleasure and the Text. Arethusa, vol. 22: 81-104.

E. FRAENKEL (1980) Horace. Oxford: Oxford University Press.

D. FREDERICK (1995) "Beyond the Atrium to Ariadne: Erotic Painting and Visual

Pleasure in the Roman House". Classical Antiquity, Vol. 14, No. 2, pp. 266-288. 
L. FULKERSON (2005) The Ovidian Heroine as Author. Cambridge, UK: Cambridge University Press.

M. R. GALE (1997) "Propertius 2.7: Militia Amoris and the Ironies of Elegy". The Journal of Roman Studies, Vol. 87, pp. 77-91.

C. GASPARRI. (2009) Le sculture Farnese. I. Le sculture ideali. Napoli: Electa

E. N. GENOVESE (1973) "Tardus Amor" (1.1.17-18), The Classical Journal, Vol. 68, No. 2, pp. 138-143.

G. GIANGRANDE (1974) Los Topicos Helenisticos en La Elegia Latina. Madrid: Emerita, 42, pp. 1-36.

R. GIBSON, S. GREEN, A. SHARROCK (ed.) (2006) The Art of Love. Bimillenial essays on Ovid's Ars Amatoria and Remedia Amoris. New York: Oxford University Press.

M. C. GUERRIERI, N. GIUSTOZZI (ed.) (2007) Eros. Milano: Electa.

H. C. GUNTER (ed.) (2006) Brill's Companion to Propertius. Leiden, Boston: Koninklijke Brill NV.

K. GUTZWILLER (2007) A Guide to Helenistic Literature. Malden, MA: Blackwell Publishing.

(1998) Poetic Garlands. London: University of California Press.

J. A. HANSEN (2006) Categorias epiditicas da ekphrasis. REVISTA USP, São Paulo, n. 71, p. 85-105, setembro/novembro.

S. HARRISON (ed.). (2008) The Cambridge Companion to Horace. Cambridge: Cambridge University Press.

S. J. HARRISON (ed.) (1990) Oxford Readings in Vergil's Aeneid. Oxford: Oxford University Press.

A. P. HASEGAWA (2010) Dispositio e Distinção de Gêneros nos Epodos de Horácio. Estudo Acompanhado de Tradução em Verso. Tese Apresentada ao Programa de Pós-Graduação em Letras Clássicas e Vernáculas da Faculdade de Filosofia, Letras e Ciências Humanas da Universidade de São Paulo. São Paulo.

S. J. HEYWORTH (2007) Cynthia. A Companion to the Text of Propertius. Oxford: Oxford University Press.

R. HUNTER (2006) The Shadow of Callimachus. Cambridge: Cambridge University Press.

G. O. HUTCHINGSON (2008) Talking Books. Readings in Hellenistic and Roman Books of Poetry. Oxford: Oxford University Press. 
D. F. KENNEDY (1993) The arts of Love. Five studies in the discourse of Roman love elegy. New York and Victoria: Cambridge University Press.

D. E. E. KLEINER (1992) Roman Sculpture. New Haven and London: Yale University Press.

P. KNOX (ed.) (2009) A Companion to Ovid. Malden: Wiley Blackwell.

M. LABATE (1994) “Critica del discorso amoroso: orazio e l'elegia”. In: J. C. F. CORTE, R. T. CORTÉS (org.) Bimilenario de Horacio. Salamanca: Ediciones Universidad de Salamanca.

H. LAUSBERG (2004) Elementos de Retórica Literária. Lisboa: Fundação Calouste Gulbekian.

(2003) Manual de Retórica Literaria. Tomos I e II. Fundamentos de una ciencia de la literatura. Version Espanõla de José Pérez Riesco. Biblioteca Románica Hispánica. Madrid: Editorial Gredos.

J. L. LiGHTFOOT (1999) Parthenius de Nicaea. The Poetical Fragments and the Erotika Pathémata. Oxford: Oxford University Press.

R. LING (2009) Roman Painting. Cambridge: Cambridge University Press.

M. LOWRIE (ed.) (2009) Horace: Odes and Epodes. Oxford: Oxford University Press.

R. O. A. M. LYNE (1974) Propertius I 5. Mnemosyne, Fourth Series, Vol. 27, Fasc. 3, pp. 262-269.

(1998) 'Propertius 2.10 and 11 and the Structure of Books ' $2 \mathrm{a}$ ' and '2b'”, London: JRS, 88, pp.21-36.

(2007) Collected Papers on Latin Poetry. Oxford: Oxford University

Press.

A. MAIURI (1960) Pompeian wall paintings (Orbis pictus). Hallwag. (1964) Paintings from Herculaneum and Stabia. Milano: Aldo Martello. (1953) The Great Centuries of Painting: Roman Painting. Geneva: Skira. (1951) Pompeii. Novara: Instituto Geográfico de Angonstin.

P. MARTINS (2011) Imagem e Poder. Considerações sobre a representação de Otávio Augusto. São Paulo: Editora da Universidade de São Paulo. (2005) Eneias se reconhece. In: Letras Clássicas, 5. São Paulo: Humanitas. (2009) Elegia Romana - Construção e Efeito. São Paulo: Humanitas. 
(2012) Ekphrasis, Digression and Elegy and the Reception of Propertius

Second Book. Apresentação no XVIII Congresso Nacional Estudos Clássicos. Rio de Janeiro. Texto inédito.

(2011) Breve Crítica à História da Literatura Latina. Clássica (São Paulo), v. 21.2, p. 189-204.

(2010) Polignoto, Páuson, Dionísio e Zêuxis - Uma leitura da pintura clássica grega. Phaos (UNICAMP), v. 8, p. 99-122.

(2010) Parataxe e Imagines. Revista de Estudos Filosóficos e Históricos da Antiguidade, v. 24/25, p. 141-175.

J. MAZEL (1988) As metamorfoses de Eros. O Amor na Grécia Antiga. São Paulo: Martins Fontes Editora Ltda.

R. V. MERRIL (1944) "Eros and Anteros”. Speculum, Vol. 19, No. 3, pp. 265-284.

P. A. MILLER (2004) Subjecting Verses. Latin Love Elegy and the emergency of the real. New Jersey: Princeton University Press.

(ed.) (2002) Latin Erotic Elegy. An anthology and a reader. London:

Routledge.

J. K. NEWMAN (1997) Augustan Propertius. The Recapitulation of a Genre. Hildesheim: Spudasmata.

R. G. M. NISBET e N. RUDD (2001) A Commentary on Horace. Odes Book I. Oxford: Oxford University Press.

(2004) A Commentary on Horace. Odes Book II.

Oxford: Oxford University Press.

(2004) A Commentary on Horace. Odes Book III.

Oxford: Oxford University Press.

E. OLIENSIS (1998) Horace and the Rhetoric of Authority. Cambridge: Cambridge University Press.

G. B. ONELLEY (2010) "Calímaco e Catulo: A Cabeleira de Berenice". Revista de História e Estudos Culturais, Vol. 7, No 2, pp. 1-13.

E. PANOFSKY (1967) Studies in Iconology, Humanistic Themes in the Art of Renaissance. New York: Harper \& Row.

U. PAPALLARDO (2009) The Splendor of Roman Wall Painting. Los Angeles: Getty Publications.

T. D. PAPANGHELIS (2009) Propertius: A Hellenistic Poet on Love and Death. Cambridge: Cambridge University Press. 
C. A. PERKINS (1993) "Love's Arrows Lost: Tibullan Parody in "Amores 3.9"." The Classical World, Vol. 86, No. 6, pp. 459-466

R. PICHON (1991) "De Sermone amatorio apud Latinos elegiarum scriptores". In: Index Verborum Amatoriorum, pp. 75-303. Georg Olms Verlag: Hildesheim, Zurich, New York.

J. B. T. PRADO (1990) Elegias de Tibulo. Introdução, Tradução e Notas. Dissertação de Mestrado: Departamento de Letras Clássicas e Vernáculas da Faculdade de Filosofia, Letras e Ciências Humanas da Universidade de São Paulo.

M. C. J. PUTNAM (1982) Essays on Latin Lyric, Elegy, and Epic. Princeton, New Jersey: Princeton University Press.

(1986) Artifices of Eternity. Horace's Fourth Book of Odes. Ithaca:

Cornell University Press.

(2006) Catullus and Horace. Poetic Interplay. Princeton: Princeton

University Press.

G. RAGUSA (2008) Imagens de Afrodite: Variações sobre a Deusa na Mélica Grega Arcaica. Tese de doutorado. São Paulo: Universidade de São Paulo.

(2005) Fragmentos de uma deusa: a representação de Afrodite na lírica de Safo. Campinas, SP: Editora da UNICAMP.

K. J. RECKFORD (1959) Some Studies in Horace's Odes on Love. TCJ, Vol. 55, No. 1, pp. 25-33.

J. D. REED. (1997) “Ovid's Elegy on Tibullus and Its Models”. Classical Philology, Vol. 92, No. 3, pp. 260-269.

G. RICHTER (1943) “A bronze Venus”. American Journal of Archaeology, Vol. 47, No. 4, pp. 365-378.

J. RIVES (1994) "Venus Genetrix outside Rome”. Phoenix, Vol. 48, No. 4, pp. 294306.

M. RODOLPHO (2010) Écfrase e Evidência nas Letras Latinas: Doutrina e Práxis.

Dissertação apresentada ao Programa de Pós-Graduação em Letras Clássicas do Departamento de Letras Clássicas e Vernáculas da FFCLH/USP. São Paulo.

A. P. ROSENMEYER (1992) The Poetics of Imitation. Anacreon and Anacreontic Tradition. Cambridge: Cambridge University Press.

T. G. ROSENMEYER (1951) Eros: Erotes. Phoenix, Vol. 5, No. 1, pp. 11-22.

V. SAMPAOLO, I. BRAGANTINI (2009) La Pittura Pompeiana. Napoli: Electa. 
M. M. SANTOS (1997) "O Monstrum da Arte Poética de Horácio”. In: Letras Clássicas. Departamento de Letras Clássicas e Modernas. FFCLH/USP. São Paulo: Humanitas.

L. SERIGNOLLI (2011) "Militia Amoris: Uma Figura do Amor" In: Coleção de Estudos Clássicos. Vol. 2. Rio de Janeiro: 7 Letras.

W. J. SLATER (1974) "Pueri Turba Minuta". University of London. Institute of Classical Studies. Bulletin n. 21, pp. 133-140.

F. A. SPENCER (1932) “The Literary Lineage of Cupid”. The Classical Weekly, Vol. 25, No. 16, pp. 121-127.

(1932) "The Literary Lineage of Cupid (Continued)". The Classical Weekly, Vol. 25, No. 17, pp. 129-134.

(1932) "The Literary Lineage of Cupid (Concluded)". The Classical Weekly, Vol. 25, No. 18, pp. 139-144.

H. P. STAHL (1985) Propertius Love and War. Individual State under Augustus. Berkeley: University of California Press.

M. H. SWINDLER (1923) Venus Pompeiana and the New Pompeian Frescoes. American Journal of Archaeology, Vol. 27, No. 3, pp. 302-313.

N. C. STAMPOLIDIS, Y. TASSOULAS (2009) (ed.) Eros. From Hesiod's Theogony to Late Antiquity. Athens: Museum of Cycladic Art.

W. J. TATUM (2000) Aspirations and Divagations: The Poetics of Place in Propertius 2.10. Transactions of the American Philological Association, Vol. 130, pp. 393410.

E. THOMAS (1964) "Variations on a Military Theme in Ovid's 'Amores",. Greece \& Rome, Second Series, Vol. 11, No. 2, pp. 151-165.

R. THOMAS (ed.) (2011) Odes, Book 4 and Carmen Seculare. Cambridge: Cambridge University Press.

P. S. VASCONCELOS (2001) Efeitos Intertextuais na Eneida de Virgílio. São Paulo: Humanitas/FFLCH - USP/Fapesp.

P. VEYNE (1991) La Elegia Erotica Romana. Mexico, DF: Fondo de Cultura Económica.

K. VOLK (2010) Blackwell Introductions to the Classical World. Ovid. Malden, MA: Wiley Blackwell.

L. C. WATSON (1983) Problems in Epode 11. The Classical Quarterly, New Series, Vol. 33, No. 1, pp. 229-238. 
University Press.

D. WEST (1995) Horace Odes I. Carpe Diem. Oxford: Oxford University Press.

R. WESTGATE. "Genre and originality in Hellenistic Mosaics". Mosaic. The jornal of ASPROM, Vol. 26, pp. 16-25.

(2000) "Pavimenta atque emblemata vermiculata. Regional styles in helenistic mosaic and the first mosaics at Pompeii”. AJA, Vol. 104, No. 2, pp. 255-275.

A. WLOSOK (1975) Amor and Cupid. Harvard Studies in Classical Philology, Vol. 79, pp. 165-179.

H. WOMBLE. (1970) "Horace, Carmina, 1. 2". The American Journal of Philology, Vol. 91, No. 1, pp. 1-30.

M. WYKE (2007) The Roman Mistress. Ancient and Modern Representations. Oxford: Oxford University Press.

P. ZANKER (1998) Pompeii Public and Private Life. Translated by Deborah Lucas Schneider. London: Cambridge University Press.

(1998) The Power of Images at the Age of Augustus. Translated by Alan Shapiro. Ann Harbor: The University of Michigan Press. 